RENATO TAVARES J UNIOR

\title{
Educomunicação e expressão comunicativa: a produção radiofônica de crianças e jovens no projeto educom.rádio
}

Dissertação apresentada ao Programa de Pós-Graduação em "Ciências da Comunicação", Área de "Interfaces Sociais da Comunicação", Linha de Pesquisa "Educomunicação", da Escola de Comunicações e Artes da Universidade de São Paulo (ECA/USP), como exigência parcial para obtenção do Título de Mestre em Ciências da Comunicação, sob a orientação do Prof. Dr. Ismar de Oliveira Soares.

São Paulo

2007 


\title{
$\underline{\text { Resumo }}$
}

A dissertação investiga a consolidação do novo campo autônomo da Educomunicação, com ênfase na área da “mediação tecnológica na educação”, tendo como objeto de pesquisa produções radiofônicas vinculadas ao projeto "educom.rádio”, implementado pelo NCEUSP (Núcleo de Comunicação e Educação) junto a 455 escolas da rede municipal de ensino de São Paulo entre 2001 e 2004.

Propõe-se a investigar quantitativamente centenas de programas de rádio realizados por professores e estudantes que participaram do projeto e a analisar qualitativamente a continuidade das práticas educomunicativas de produção radiofônica nas escolas, nos dois anos subseqüentes ao projeto “educom.rádio”, em 2005 e 2006.

A pesquisa pretende elucidar em que condições e com que resultados ações educomunicativas podem melhorar os processos comunicativos nas escolas e ainda estimular o protagonismo infanto-juvenil, potencializando a capacidade expressiva de crianças e jovens, tornando-os cidadãos mais críticos e criativos.

Palavras-chave: Educomunicação, Comunicação, Educação, rádio, mediação tecnológica.

\begin{abstract}
$\underline{\text { Abstract }}$
This thesis investigates the consolidation of a new academic field called educommunication. The emphasis is to analize radio productions under the technology mediation perspective in education, at a specif project identified as "educom.radio", developed by the Nucleus of Communication and Education of the University of São Pualo, in 455 São Paulo's public schools, since 2001 until 2004.

We intend to make a quantitativity investigation of more than 600 radio programms produced by teachers and students. We also inted to go ahead in two years after the end of "educom.radio", presenting a qualitivity analysis of the educommnunication activities with radio productions at São Paulo public schools, in 2005 and 2006.

The research elucidates the conditions and the results of educommunication actions to improve the communication process at schools and to estimulate children and teens participation in educational communities real life, in order to increase their expression habilities and to help them to become more critc and creative citzens.
\end{abstract}

Keywords: Educommunication, Communication, Education, radio, mediation technology. 


\section{Agradecimentos}

Agradeço, primeiramente, o apoio fundamental da minha família para a realização dessa dissertação, especialmente de Maria Margarida e Jessy, e a paciência e a confiança do meu orientador, o professor Ismar de Oliveira Soares. Agradeço, ainda, ao NCE-USP e à ECA-USP, especialmente pelas contribuições dos doutorandos Patrícia Horta Alves e Richard Romancini e dos professores Eduardo Vicente e Marília Franco.

Gostaria de agradecer, também, as contribuições de Carlos Alberto Mendes de Lima, da Diretoria de Orientação Técnica da Secretaria de Educação da Prefeitura de São Paulo; do aluno Antônio Gustavo e do professor César de Paula Júnior da EMEF Euclides de Oliveira Figueiredo; da assistente de direção Margareth Russo e das professoras Anna Maria Morais

e Lígia Rodrigues da EMEF José Bonifácio; do secretário Amauri Ruz, da coordenadora Célia Sevilha e do aluno Felipe Alves da EMEF Paulo Colombo Pereira; da aluna Laila El Alam e dos oficineiros Érika Brasil e Luiz Fernando Alves da EMEF Professor Carlos Pasquale. 


\section{Sumário}

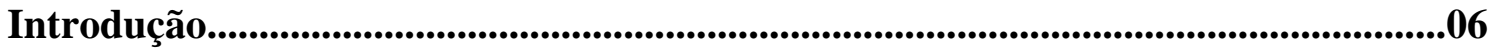

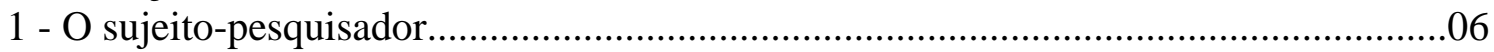

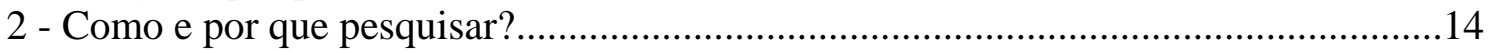

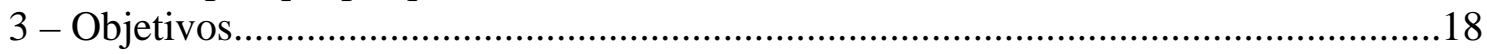

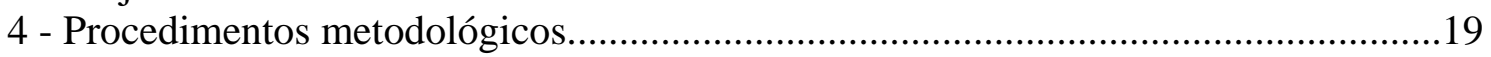

Capítulo 1 - A inter-relação Comunicação/Educação: das novas linguagens e tecnologias à contextualização política de um novo campo de estudo.....................23

1.1 - O avanço tecnológico e as mudanças na sociedade..............................................23

1.2 - As novas tecnologias de comunicação no espaço escolar.......................................30

1.3 - Comunicação e Educação: inimigas, vizinhas, irmãs? O que dizem as teorias?...44

1.4 - Comunicação/Educação: intersecção ou campo autônomo?..................................60

\section{Capítulo 2 - A Educomunicação e os fundamentos teóricos do}

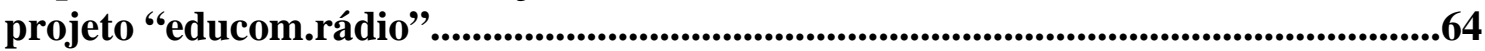

2.1 - Educomunicação: a consolidação de uma teoria....................................................64

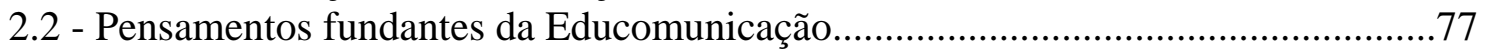

2.3 - A área da "mediação tecnológica na educação"....................................................83

2.4 - Educomunicador: o perfil de um novo profissional................................................95

2.5 - Educomunicação: do diálogo nacional com a LDB à lei municipal em São

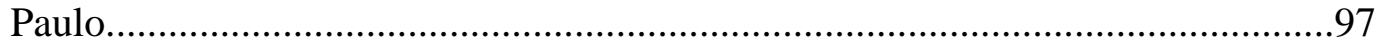

Capítulo 3 - O projeto “educom.rádio”: da concepção à avaliação...........................101

3.1 - Formulação e desenvolvimento do projeto..........................................................101

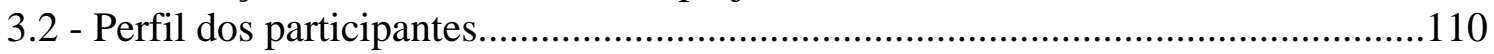

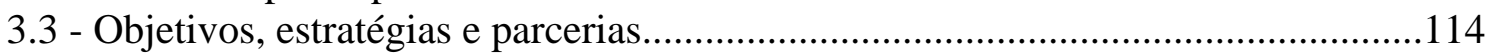

3.4 - A continuidade das idéias e das práticas...............................................................127

Capítulo 4 - O rádio no “educom”....................................................................131

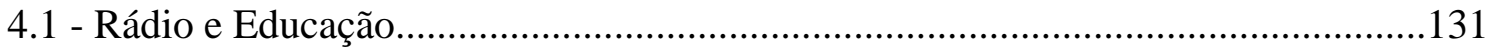

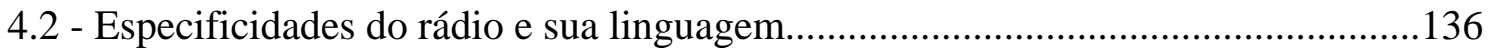

4.3 - A opção pelo rádio em projetos educativos e educomunicativos..........................138

Capítulo 5 - 0 “educom” no rádio: análise das produções radiofônicas

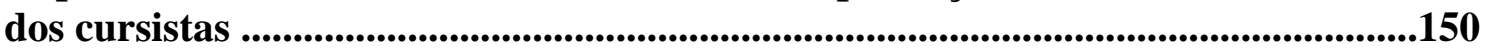

5.1 - Universo, amostragem e categorias de classificação.....................................150

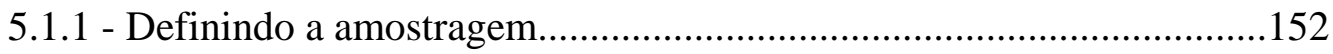

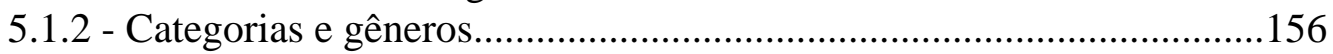

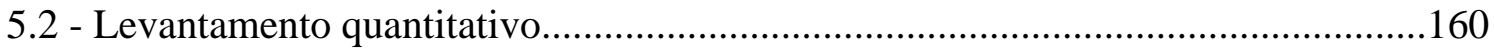

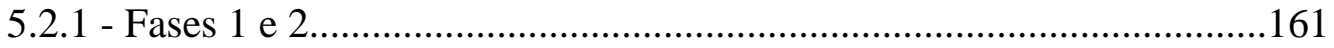

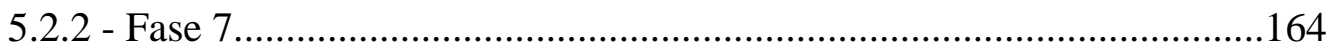

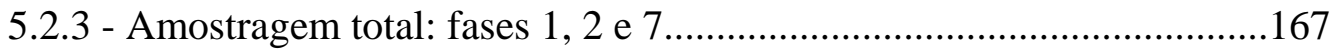


5.3 - Análise quantitativa das produções radiofônicas...................................................170

5.3.1 - Evolução do projeto...........................................................................170

5.3.2 - A participação dos professores.........................................................177

Capítulo 6 - Do uso do rádio ao uso da rádio: as produções radiofônicas nas escolas públicas de São Paulo após o “educom”..........................................................181

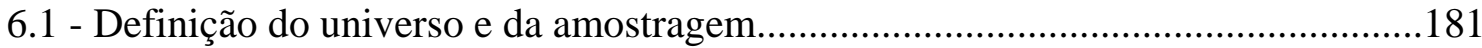

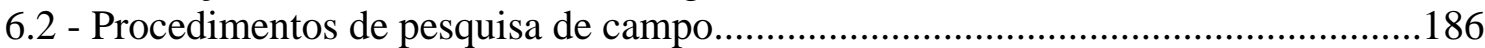

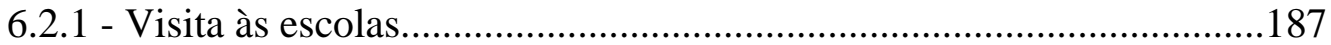

6.2.2 - Entrevistas com membros da comunidade escolar.............................189

6.2.3 - Aplicação de questionários...................................................................191

6.2.4 - Entrevista com o coordenador do projeto "Educom nas ondas

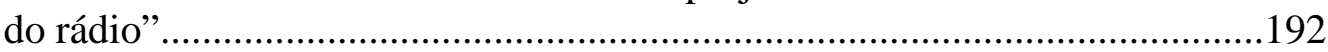

6.3 - Sistematização dos dados colhidos por meio das visitas às escolas e das

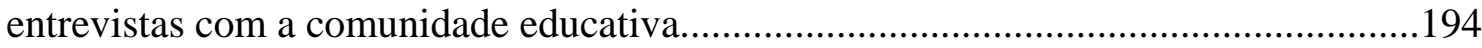

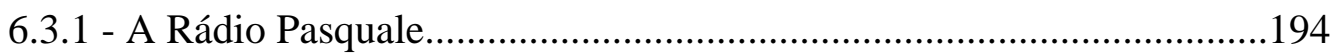

6.3.2 - A Rádio Sensação..................................................................................201

6.3.3 - A Rádio Boni................................................................................211

6.3.4 - A Rádio Interferência e a Rede Interferência......................................222

Capítulo 7 - O desenvolvimento dos jovens educomunicadores: a opinião de

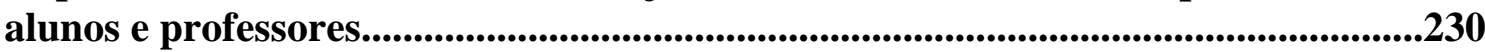

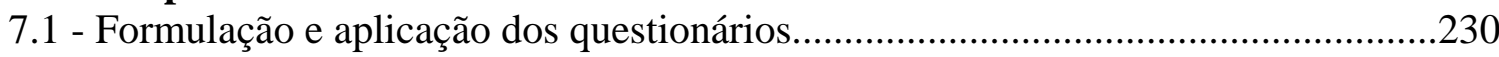

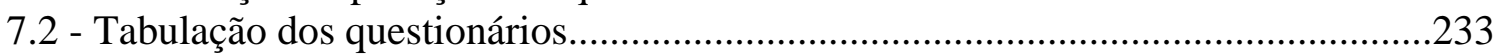

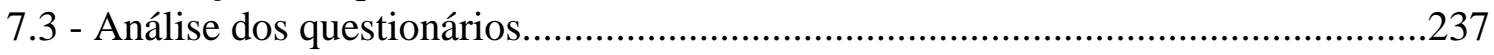

Capítulo 8 - A produção radiofônica nas escolas de São Paulo: a visão do poder público municipal....................................................................................................250

Capítulo 9 - Conclusões e considerações finais................................................................255

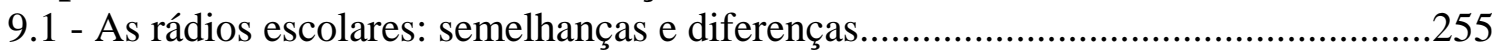

9.2 - Perspectivas para as ações educomunicativas......................................................262

Bibliografia......................................................................................................269

Anexo I - Roteiro de perguntas abertas para estudos de caso nas escolas...............275

Anexo II - Modelo de questionário para alunos.............................................................2278

Anexo III - Modelo de questionário para professores e coordenadores..................279 


\section{Introdução}

\section{1 - O sujeito-pesquisador}

Ao defender a vigilância epistemológica e o rigor acadêmico necessários à pesquisa de Pós-Graduação, Maria Immacolata Vassalo de Lopes $^{1}$ alerta para a importância de se evidenciar o sujeito que existe por trás do pesquisador bem como os motivos que o levaram a definir sua problemática, além de explicitar a relação entre o próprio sujeito e seu objeto de pesquisa.

Meu primeiro contato com a Educomunicação ocorreu em 2001, quando estava no terceiro ano do curso de "Rádio e Televisão" na Universidade de São Paulo. Fiquei interessado em participar do “educom.rádio”, um projeto que usaria a linguagem radiofônica em escolas públicas. Ingressei na equipe do Núcleo de Comunicação e Educação da mesma universidade (o NCE-USP) e descobri que estava diante de algo muito maior do que participar de um projeto para exibir programas de rádio nas escolas. Fui percebendo que estava entrando em contato com uma nova teoria em consolidação que utilizava elementos da Comunicação e da Educação e conseguia ir muito mais além do que apenas propor uma leitura crítica da mídia por alunos e professores.

Lembrei-me de minha infância e adolescência quando sozinho em casa fazia alguns programas de rádio usando apenas um gravador de mão para "estudar de uma forma mais divertida” para as provas e “treinar” a leitura e a dicção. Infelizmente não existiam projetos educomunicativos nas escolas em que estudei, mas apenas raras iniciativas isoladas como a

\footnotetext{
1 - Maria Immacolata Vassallo de LOPES. Pesquisa em Comunicação. São Paulo, Loyola, $7^{\mathrm{a}}$ ed, 2003
} 
realização de um jornal-mural numa aula de Língua Portuguesa e a produção de um vídeo para a aula de Geografia.

Comecei a perceber que o projeto de Educomunicação em que estava inserido soava como novidade no ambiente escolar e enfrentava resistências em várias instâncias. Por mais contraditório e absurdo que parecesse, a simples inserção na escola do rádio (um veículo que tem mais de 80 anos de existência no Brasil) ecoava, para muitos, como uma estranha novidade. Com as reuniões internas de formação da equipe de trabalho do projeto foi ficando claro, para mim, que não era apenas o produto final que importava, mas o processo de realização dos programas envolvendo os diversos atores sociais da escola e, também, a avaliação e a valorização do processo de realização e, conseqüentemente, da aprendizagem, da gestão democrática, do diálogo, etc.

Nas fases finais do projeto “educom.rádio” acompanhei mais de perto a participação dos alunos (crianças e adolescentes, em média de 9 a 14 anos) nas atividades educomunicativas. Passei a me interessar mais pela Educomunicação e pude descobrir, na prática, o significado de "protagonismo infanto-juvenil”, verificando como o educando pode ser o ator principal de seu processo de desenvolvimento, ampliando sua capacidade de interferir de forma ativa, construtiva e solidária em âmbito escolar e na relação com a comunidade.

Notei mudanças no comportamento e nas atitudes dos jovens participantes durante os doze sábados que totalizavam 96 horas de encontros presenciais por semestre. Percebi que os jovens queriam se expressar por outras linguagens e tinham muito para dizer. Identifiquei jovens que começavam o curso tímidos e terminavam falantes, ativos, propositivos, etc... Outros que tinham fama de rebeldes, indisciplinados e chegavam ao fim 
do curso muito mais responsáveis, provando para os companheiros que também tinham boas idéias e eram capazes de se expressar de forma criativa.

Após a conclusão do curso superior de “Rádio e Televisão” e interessado em ingressar na Pós-Graduação, percebi que estava diante de um rico objeto de pesquisa, no qual poderia:

- investigar e analisar a questão da mediação tecnológica na educação;

- discutir o uso social das tecnologias de informação e comunicação na escola;

- saber como crianças e jovens se comportam diante da possibilidade de se expressarem por outras linguagens que estão mais próximas de seu cotidiano;

- investigar o que eles querem falar, para quem querem falar e como querem falar;

- pesquisar se e como projetos educomunicativos podem trazer vantagens e benefícios para os alunos tanto na opinião dos próprios jovens como na visão de professores e funcionários.

Ao ser aceito na ECA para fazer o mestrado sob a orientação do Prof. Dr. Ismar de Oliveira Soares, vislumbrei a possibilidade de realizar uma pesquisa numa universidade pública que tivesse utilidade tanto para o campo acadêmico como para a própria sociedade. Era o que imaginava poder ocorrer ao optar por analisar projetos de intervenção social como o "educom.rádio”, contribuindo com indagações e sugestões para a melhoria e a ampliação das possibilidades de um ensino voltado para o interesse das crianças e dos jovens possibilitando, desta forma, uma reflexão acadêmica sobre a inter-relação Comunicação/Educação. A intenção era trazer o olhar de alguém formado na área da Comunicação (com habilitação em rádio e televisão) e que se interessava pelo potencial educativo dos recursos tecnológicos de comunicação e por sua aplicação na sociedade. 
Percebi que muitas atividades práticas foram e vêm sendo realizadas em escolas, Organizações Não-Governamentais e centros culturais enquanto diversas correntes teóricas, às vezes antagônicas, ainda discutem as possíveis inter-relações entre Comunicação e Educação.

Apesar do crescente volume de pesquisas, dissertações e teses sobre o tema ${ }^{2}$, fiquei inquieto ao notar que muito pouco havia sido pesquisado no que diz respeito à grande quantidade de produções midiáticas realizadas pelos sujeitos atendidos por projetos que inter-relacionam Comunicação e Educação. Descobri que, depois das pesquisas que evidenciaram a existência do campo da Educomunciação, notadamente o trabalho coordenado pelo Prof. Dr. Ismar de Oliveira Soares, com a participação de Patrícia Horta Alves e Eliany Salvatierra, entre outros colaboradores, o projeto investigativo mais próximo, desenvolvido na ECA-USP, tendo como foco específico a produção midiática no campo em questão, foi a tese de doutorado de Genésio Zeferino Filho, também orientando do Prof. Ismar Soares. Intitulada Educomunicação e sua Metodologia: um estudo a partir de práticas de ONGs no Brasil, a pesquisa abordou a natureza das relações pedagógicas próprias do trabalho das organizações não-governamentais que optaram por implementar o uso das tecnologias da comunicação em seus trabalhos com grupos de crianças e adolescentes. No caso, optei por dar continuidade a este tipo de pesquisa, tendo, agora, como objeto, um produto do próprio NCE-USP: a produção radiofônica dos alunos do “educom.rádio”.

Decidi, também, que buscaria ir além de uma pesquisa que analisasse somente um determinado período de um projeto com a descrição de seus encontros presenciais e dos

\footnotetext{
2 - Segundo o Banco de Dados da Biblioteca da ECA, disponível no site www.rebeca.eca.usp.br, estão catalogadas 54 teses e dissertações sobre a inter-relação Comunicação/Educação, de alguma forma relacionadas com o campo da Educomunicação.
} 
materiais utilizados, mas também investigar a continuidade das aplicações práticas quando houvesse terminado o período de formação do projeto. A intenção era saber como a “mediação tecnológica”, identificada por Soares como uma das áreas de intervenção do campo da Eduocmuicação, permanecia produzindo resultados nas escolas públicas após o término dos encontros de formação com assessoria especializada.

Acompanhei as fases finais do projeto “educom.rádio" e identifiquei que os coordenadores também estavam preocupados com a continuação dos efeitos da capacitação. Nesse sentido passaram a dar maior importância às atividades práticas de realização de produtos radiofônicos, à sua catalogação por meio de banco de dados, à sua digitalização para criação e manutenção do acervo e divulgação (por meio da Internet). Por outro lado, percebi que ao longo das diferentes fases do projeto, os cursistas (alunos, professores e funcionários) também ficaram mais receptivos ao projeto mediante o aumento do número de atividades práticas que incluíam a realização de programas radiofônicos. Tornaram-se evidentes a vontade e a necessidade que principalmente os jovens tinham de se expressar melhor por meio das novas linguagens.

De minha parte, ao longo dos anos de 2001, 2003 e 2004, mantive contato direto com o projeto atuando como "mediador”3 em escolas públicas durante atividades teóricas e práticas. Além disso, integrei a equipe de “Memória Audiovisual” do NCE-USP que, entre outras funções, digitalizava e disponibilizava produções radiofônicas dos cursistas na Internet por meio do site www.usp.br/educomradio.

\footnotetext{
3 - Os mediadores se reuniam com grupos de alunos, professores e funcionários das escolas públicas de São Paulo com o objetivo de esclarecer o conceito da Educomunicação, além de propor e orientar atividades práticas de produção midiática (principalmente de áudio e rádio) estimulando a gestão participativa e democrática. O mediador agia como um facilitador das ações da comunidade escolar propondo de forma prática o aumento do coeficiente comunicativo das atividades educativas. O perfil dos mediadores e sua função no "educom.rádio" foi objeto de pesquisa de mestrado de Claudia Funari, junto ao programa de pósgraduação da ECA/USP, defendida em 2007.
} 
Durante o projeto “educom.rádio” identifiquei e convivi com bons exemplos de protagonismo infanto-juvenil não só na relação dos jovens com outros jovens, como também nas atividades coletivas com adultos (professores, funcionários e membros da comunidade). É importante analisar a capacidade da comunidade educativa de multiplicar os conteúdos e as técnicas aprendidas de modo a ampliar as atividades educomunicativas na escola, integrando novos alunos ao processo, dialogando com outros professores e funcionários, inserindo, em alguns casos, toda a comunidade nos processos participativos de produção midiática.

Além do “educom.rádio”, aprofundei meus conhecimentos práticos e teóricos sobre a Educomunicação trabalhando em outros projetos, como na concepção do "educom.mídia”4, que seria desenvolvido nos CEUs (Centro Educacional Unificado) da Prefeitura de São Paulo, prevendo a implantação de laboratórios multimídia e o uso integrado do som, da fotografia, do vídeo, da mídia impressa e da Internet. Por questões políticas, o projeto previsto para ser realizado a partir de março de 2004, não chegou a ser implementado. No entanto, colaborou para que o NCE-USP aperfeiçoasse sua maneira de elaborar

\footnotetext{
4 - O "Programa de formação em Educomunicação através do uso da multimídia” - "educom.mídia”, desenhado pelos professores Ismar de Oliveira Soares, Marília Franco e Patrícia Horta, previa uma assessoria do NCE-USP no sentido de promover cursos presenciais de difusão cultural sobre Educomunicação no espaço dos CEUs, prevendo especialmente atividades práticas nas áreas das expressões sonora, visual, verbal e interativa, visando a capacitar a comunidade escolar para a produção midiática em suportes como arquivos de áudio, fotografias, textos, boletins, jornais impressos, programas de rádio, vídeos, programas de TV e sites. A proposta previa trabalhos por projetos, estimando que, ao final de 12 meses, um mínimo de 400 pessoas estaria apta, em cada CEU, para implementar o uso do audiovisual no espaço escolar, sob a perspectiva da Educomunicação. No desenho deste projeto, coube-me integrar a equipe que elaborou a proposta para a aquisição de um estúdio multimídia para cada CEU. Um total de 21 estúdios foram adquiridos e finalmente doados aos CEUs pelo Banco Santander. Com os equipamentos em mãos, a Secretaria de Educação preferiu entregar seu uso a pequenas ONGs de São Paulo, a um custo muito superior ao previsto no projeto "educom.mídia", rejeitando, sumariamente, por telefone, 20 dias antes o início do trabalho do NCE, a esperada colaboração da USP. No caso, a Prefeitura demonstrava preferir a metodologia do oficinismo isolado e desconectado da realidade local de cada escola, ao processo de mediação tecnológica teoricamente assistida, proposta pela Universidade de São Paulo. O resultado dessa política refletiu-se na não instalação dos estúdios entregues em cada CEU, no desaparecimento de muitos equipamentos e na ausência de uma política coerente para o uso dos recursos tecnológicos nos espaços educativos dos CEUs.
} 
planejamentos de iniciativas voltadas à formação de docentes e educandos nas áreas das mídias verbal, visual, sonora e interativa.

Ainda em 2004, participei do projeto “educomradio.centro-oeste”5 acompanhando estudantes do Ensino Médio de escolas públicas das cidades de Cuiabá e Várzea Grande (Mato Grosso) na concepção e realização de programas radiofônicos durante a 56ª reunião anual da SBPC (Sociedade Brasileira para o Progresso da Ciência). Além disso, a aproveitei para captar imagens e entrevistas em vídeo para o institucional do projeto.

Em 2005, acompanhei a participação de jovens estudantes de escolas públicas e do Colégio São Luís (de São Paulo) no "Encontro Internacional África-Brasil”6. Co-dirigi um documentário sobre diversidade racial incluindo a realização de programas radiofônicos desses grupos de jovens e sua veiculação via Internet. No final do mesmo ano, por meio do NCE-USP, participei da concepção dos primeiros módulos para um curso a distância do MEC (Ministério da Educação) chamado "Formação Continuada em Mídias na Educação"7. Já, em 2006, escrevi alguns textos para o site do curso, elaborei atividades para os cursistas, selecionei e editei programas de rádio realizados em instituições

\footnotetext{
5 - O "educomrádio.centro-oeste" foi um projeto que teve como eixo estruturante um curso de educação a distância viabilizado por um convênio entre o NCE-USP a Secretaria de Educação a Distância (SEED) do Ministério da Educação (MEC) para atender a professores de 70 escolas públicas dos estados de Goiás, Mato Grosso e Mato Grosso do Sul. Apesar do predomínio do curso a distância, por meio de um site desenvolvido pelo NCE-USP, houve também algumas reuniões presenciais com os cursistas. Um dos encontros realizados em Cuiabá coincidiu com a semana da $56^{a}$ reunião anual da SBPC, razão pela qual o NCE-USP viabilizou a participação de estudantes de algumas escolas da capital matogrossense e da cidade vizinha Várzea Grande para desenvolverem a cobertura radiofônica do evento.

${ }^{6}$ - O Encontro Internacional África Brasil foi promovido pelo IIJC (International Institute of Journalism and Communication), pelo NCE-USP e pelo SESC São Paulo, entre 12 e 15 de outubro de 2005, sob coordenação-geral do professor Ismar de Oliveira Soares, reunindo jornalistas, autoridades, artistas e pesquisadores para discussão do tema "igualdade racial: um desafio para a mídia”. O NCE-USP convidou e capacitou crianças e adolescentes do Colégio São Luís (privado) e de escolas da rede pública municipal de São Paulo (que haviam participado do "educom.rádio") para realizarem produções radiofônicas sobre os principais temas discutidos no evento de modo a transmitirem programas ao vivo pela internet e também veiculá-los posteriormente nas rádios de suas escolas.

7 - O curso a distância "Formação Continuada em Mídias na Educação" utiliza a plataforma "E-proinfo" para atender a 10 mil professores de todos os estados brasileiros. O NCE-USP foi a instituição incumbida de produzir os quatro módulos básicos da mídia rádio (sendo três de 15 horas e um de 30 horas) aprofundando a discussão do uso do rádio como prática educativa.
} 
educativas e culturais além de vídeos que mostravam práticas educomunicativas em projetos do NCE-USP.

Durante o ano de 2006, também auxiliei o NCE-USP em parte da concepção do projeto “educom.geraçãocidadã»,8 financiado pelo MTE (Ministério do Trabalho e Emprego) em seis cidades da Grande São Paulo. Fui mediador de duas turmas de cerca de 45 jovens entre 16 e 24 anos durante três meses, totalizando 105 horas/aula de formação para cada turma. Durante este período orientava os alunos para a realização de blogs (contemplando gêneros textuais literários e informativos) e também produções radiofônicas. Em março do mesmo ano, dirigi e roteirizei os vídeos institucionais do projeto apresentados por dois jovens cursistas.

Diante dessas experiências, pude presenciar como a criança e o adolescente aprendem melhor quando vêem ou ouvem outro jovem contando, analisando, comentando ou explicando algo para ele. Ficou evidente a necessidade de se pesquisar como projetos que relacionem as áreas de Educação e Comunicação podem ser úteis e eficazes para o desenvolvimento do protagonismo infanto-juvenil, preparando a criança e o jovem para a expressão por diferentes linguagens, para uma postura mais ativa, crítica e criativa, para o desenvolvimento de outras inteligências (como defende Gardner ${ }^{9}$ ) e não só as racionais, para uma alfabetização múltipla (como explica Orozco $^{10}$ ), para a problematização e a

\footnotetext{
8 - O "educom.geração cidadã” integrou o módulo básico de Educomunicação do Consórcio Social da Juventude, sediado em Embu das Artes, entre dezembro de 2005 e março de 2006, atendendo a 2000 cursistas das cidades de Taboão da Serra, Embu das Artes, Embu-Guaçu, Itapecerica da Serra, Juquitiba e São Lourenço da Serra. O NCE-USP promoveu, para cada turma de 45 alunos, 33 encontros, sendo 11 destinados à abordagem de temas transversais (como democratização da comunicação, Educomunicação, diversidade cultural), 11 dedicados à produção de conteúdo para blogs dos alunos e outros 11 voltados para a realização de programas de rádio. No encerramento do módulo básico o NCE-USP promoveu, na sede do Consórcio, na cidade de Embu das Artes, um simpósio de Educomunicação.

9 - Howard GARDNER. Estruturas da mente. A teoria das inteligências múltiplas. Porto Alegre, Artes Médicas Sul, 1994.

10 - Guillermo OROZCO. "Elementos para uma política de educación mediática”. In VALDERRAMA, Carlos. Comunicación-Educación, Coordinadas, abordajes y travesías. Universidad Central/DIUC, Bogotá, 2000
} 
interação com seu cotidiano (como pregava Paulo Freire ${ }^{11}$ ) para a democratização dos meios de comunicação e o resgate da cidadania.

Estando atento a fim de não pender para uma visão extremamente utópica ou positiva da tecnologia, pretendo investigar como o adequado uso dos recursos de informação e comunicação pode contribuir para que o defasado sistema de educação se atualize com as necessidades do século XXI e transforme crianças e jovens em produtores de cultura e de sentidos.

\section{2 - Como e por que pesquisar?}

O acelerado desenvolvimento tecnológico e a influência cada vez maior dos meios de comunicação na sociedade têm suscitado discussões, análises e previsões em torno da relação entre áreas do saber como Comunicação e Educação. Em meio a teorias sobre a passagem da modernidade para a pós-modernidade, muitos conceitos e estudos ressaltam a importância de se analisar e compreender como os campos da Educação e da Comunicação podem se inter-relacionar ou até mesmo formar e consolidar um novo campo autônomo interdiscursivo e transdisciplinar.

Nas últimas décadas surgiram vários conceitos como "Media Education”, “Media Literacy”, “Information Literacy”, “Comunicação Educativa”, “Educação a distância”, “Tecnologia Educativa”, “Informática Educativa”, “Educação Mediática” e

\footnotetext{
11 - Paulo FREIRE. Extensão ou Comunicação. Editora Paz e Terra, Rio de Janeiro, 1979
} 
"Educomunicação”. As diversas teorias enfocam desde as diferentes tendências de leitura crítica dos meios de massa até a gestão da comunicação em espaços educativos, passando pelo uso das tecnologias de informação no espaço escolar, constituindo-se este último na problemática desta pesquisa: a “mediação tecnológica na educação”, uma das áreas da Educomunicação, segundo a divisão proposta pelo professor brasileiro Ismar de Oliveira Soares.

Diante da necessidade que se mostra cada vez mais urgente de tentar compreender como as instituições escolares podem se apropriar dos meios de comunicação bem como descobrir como são as novas formas de agir, sentir e se expressar de crianças e adolescentes consideramos relevante pesquisar, analisar, refletir e apontar tendências sobre como e em que condições projetos educativos que utilizem as novas tecnologias de comunicação e informação podem potencializar a capacidade expressiva dos jovens tornando-os cidadãos mais autônomos, críticos, criativos e participativos.

É importante destacar que nossa análise partirá do reconhecimento de que se está consolidando, tanto na teoria como principalmente em projetos práticos de intervenção social, um novo campo científico denominado Educomunicação ${ }^{12}$. Trata-se de um termo inicialmente utilizado pelo estudioso uruguaio Mario Kaplún para conceituar a "leitura crítica dos meios” e depois ressemantizado e ampliado por Ismar de Oliveira Soares, que sinalizou para a emergência do novo campo que se consubstancia por meio de áreas que, além da “educação para a comunicação", contemplam a “mediação tecnológica na

\footnotetext{
12 - O NCE-USP promoveu, entre 1997 e 1998, uma pesquisa junto a 178 especialistas de 12 países das áreas da Comunicação e da Educação, por meio de um questionário exploratório e 25 entrevistas em profundidade, buscando identificar como se entendia, na América Latina, a relação entre Comunicação e Educação. Os resultados da pesquisa coordenada por Ismar de Oliveira Soares foram disponibilizados pela primeira vez em artigo publicado na revista Contato (Ismar de Oliveira SOARES, "Comunicação/Educação: a emergência de um novo campo e o perfil de seus profissionais” In Contato - Revista Brasileira de Comunicação, Arte e Educação num.2, Brasília, Senado Federal, jan/mar 1999, p.19-74)
} 
educação", a "gestão da comunicação em espaços educativos”, a “expressão comunicativa por meio das artes” e a "reflexão epistemológica” tanto sobre o novo campo como sobre a inter-relação Comunicação/Educação.

Soares, coordenador-geral do Núcleo de Comunicação e Educação da Universidade de São Paulo, faz questão de ressaltar que o NCE-USP não "inventou” o novo campo, mas apenas constatou sua existência na prática da sociedade civil destacando que a Educomunicação em seu diálogo interdiscursivo relaciona, entre outros elementos, a teoria comunicativa das mediações e a teoria educativa construtivista.

Definida a problemática (a Educomunicação, com ênfase na “mediação tecnológica na educação”), escolhemos como nosso problema (objeto empírico de pesquisa) a natureza e especificidades das produções radiofônicas do projeto “educom.rádio”.

Trata-se do projeto de maior abrangência e duração no campo da Educomunicação por ter atendido grupos de alunos, professores e membros da comunidade de todas as 455 escolas municipais de Ensino Fundamental da capital paulista entre julho de 2001 e dezembro de 2004. O NCE-USP elaborou um plano de sete fases semestrais de modo a oferecer a cada unidade escolar, inscrita em um dos semestres, um curso presencial de 96 horas. O programa pedagógico era composto por doze encontros, oferecidos aos sábados das 8 às 17 horas, com atividades teóricas e práticas, incluindo palestras, workshops e oficinas de produção radiofônica e elaboração de planejamento do uso do rádio em cada unidade escolar.

O contrato firmado entre a Secretaria Municipal de Educação da Prefeitura de São Paulo estabelecia que cada escola deveria receber um kit de equipamentos necessários para a instalação de uma “emissora de rádio restrita” que transmitiria para caixas acústicas dispostas em um raio de 100 metros ao redor da antena de transmissora. O Kit de 
equipamentos e acessórios incluiria também os aparatos tecnológicos necessários para a produção radiofônica (toca $\mathrm{CD}$, microfones, gravadores de mão, mesa de som, cabos, etc).

Devido à grandiosidade do projeto “educom.rádio” a análise desta pesquisa se debruçará sobre parte das produções radiofônicas produzidas por alunos, professores e funcionários de escolas paulistanas, incluindo programas:

- Realizados ao longo das atividades coordenadas pelo NCE-USP nas escolas entre 2001 e 2004;

- Produzidos em escolas públicas municipais após o término do contrato da Prefeitura de São Paulo com o NCE-USP.

Entendemos que a atual pesquisa pode ser muito útil ao tentar dar sua contribuição aos estudos da inter-relação Comunicação/Educação e ao uso das tecnologias de informação no espaço escolar a partir do momento em que além da abordagem epistemológica e histórica da aproximação entre os dois campos, propõe-se a estudar um novo campo denominado “Educomunicação” que, enquanto segue fortalecendo sua legitimidade acadêmica e científica, já serviu de base e referência a grandes (em duração e abrangência) projetos de intervenção social, como é o caso do “educom.rádio” que atendeu a todas as 455 escolas municipais da capital paulista, podendo desta forma ser considerado um "projeto de política pública” capaz de alterar o dia-a-dia e a gestão da comunicação em muitas das escolas participantes. 


\section{3 - Objetivos}

Diante do quadro que acabamos de apresentar em que constatamos que a prática pode chegar antes mesmo do reconhecimento científico de um campo em formação, pretendemos com esta pesquisa:

1) Investigar como a teoria da Educomunicação pode contribuir para a melhoria das relações de comunicação no espaço escolar e para a potencialização da capacidade expressiva de crianças e adolescentes;

2) Analisar como se deu, na prática, a concretização de centenas de produtos educomunicativos (programas radiofônicos) que se constituem em um vasto e rico material de estudo sobre o qual ainda não há levantamentos e análises, nem por parte do poder público nem da universidade.

Nesse sentido, pretendemos, finalmente, estudar até que ponto as práticas educomunicativas, resultantes de um projeto de intervenção social, podem comprovar total ou parcialmente, ou mesmo negar, as propostas teóricas da Educomunicação explicitadas nas pesquisas do NCE-USP ${ }^{13}$.

Enfim, partindo da discussão do uso social das tecnologias de informação com uma preocupação educativa e comunitária pretendemos investigar se e como projetos educomunicativos podem desenvolver ou aprimorar a capacidade expressiva e a competência comunicativa de crianças e adolescentes.

\footnotetext{
${ }^{13}$ - Ismar de Oliveira SOARES. Educommunication. Núcleo de Comunicação e Educação (NCE-USP), São Paulo, 2004.
} 


\section{4 - Procedimentos metodológicos}

Nossa metodologia explicita o papel do sujeito-pesquisador que teve relação direta com o projeto "educom.rádio" e com o NCE-USP, no qual desenvolveu atividades nos anos de 2001, 2003 e 2004, atuando como "mediador" em escolas públicas durante atividades teóricas e práticas do projeto, tendo sido integrante da equipe de "Memória Audiovisual" do NCE-USP que, entre outras funções, digitalizava e disponibilizava produções radiofônicas dos cursistas no site www.usp.br/educomradio.

Por meio de análise quantitativa de $\mathbf{6 6 8}$ programas de rádio (29,5\% do total de produções radiofônicas digitalizadas pelo NCE-USP e inseridas no banco de dados do setor de "Memória Audiovisual" do projeto ${ }^{14}$ ) de aproximadamente $\mathbf{1 3 4}$ escolas atendidas no início e no final do projeto (30\% do total de escolas participantes) pretendemos investigar os produtos radiofônicos respondendo a perguntas como:

- Quais os gêneros, formatos e temas preferidos por alunos, professores e membros da comunidade?

- Quais as características de temas e formatos que diferenciam e/ou aproximam as produções realizadas em ambiente escolar daquelas veiculadas em emissoras comerciais?

- A partir do momento em que crianças e adolescentes têm um meio para se expressar, quais assuntos e gêneros privilegiam, qual o espaço dado aos problemas locais?

\footnotetext{
14 - Ao todo, o acervo do NCE-USP contém digitalizados e catalogados em seu banco de dados 2.225 programas radiofônicos das sete fases do "educom.rádio".
} 
- Quais as diferenças entre os programas realizados apenas por alunos e os produzidos conjuntamente por estudantes, docentes e funcionários?

Nossa amostra nesta pesquisa abarcará, como foi dito, 134 escolas, sendo composta pelas:

- 66 primeiras escolas que participaram do projeto "educom.rádio” na fase $1\left(2^{\circ}\right.$ semestre/2001) e na fase 2 ( $1^{\circ}$ semestre/2002);

- 68 últimas escolas que foram atendidas na fase $7\left(2^{\circ}\right.$ semestre/2004).

Os 668 programas selecionados foram produzidos:

- Na Fase 1: 80 programas (27 escolas);

- Na Fase 2: 93 programas (39 escolas);

- $\quad$ Na Fase 7: 495 programas (68 escolas).

É importante destacar que dos 630 programas radiofônicos da Fase 7, contabilizamos 495 que dispõem no banco de dados do NCE-USP de todas as informações que consideramos relevantes para nossa pesquisa como "realizadores dos programas", “formato/gênero” e “assunto/temas”.

Como os objetivos da Educomunicação não se relacionam somente ao produto (produções midiáticas), mas principalmente ao processo (visando à construção de ecossistemas comunicativos abertos e democráticos), a pesquisa se propõe a apresentar estudos de caso com uma amostragem de escolas públicas que deram continuidade às práticas educomunicativas após o curso do “educom.rádio” realizando produções 
radiofônicas esporadicamente ou regularmente. Em relação ao processo educomunicativo, pretendemos analisar:

- Quais as facilidades e dificuldades para utilizar este meio de comunicação na escola?

- O que mudou no ambiente escolar com o uso do rádio?

- Como ocorrem o planejamento, a produção e a avaliação dos programas radiofônicos?

- O que mudou, melhorou ou piorou em relação ao desenvolvimento do educando, neste caso crianças e adolescentes do Ensino Fundamental?

Os estudos de caso poderão diagnosticar as tendências de formatos e temáticas privilegiados nas produções radiofônicas em âmbito escolar, além de investigar como se dá o uso do rádio tanto com intencionalidade pedagógica (contemplando disciplinas curriculares) como também em atividades extra-classe e extra-curriculares. Pretendemos fazer uma análise qualitativa das produções radiofônicas realizadas esporadicamente ou regularmente nas escolas que compõem a amostragem dos estudos de caso, analisando pautas, gêneros e formatos preferidos por cada comunidade escolar a partir do momento em que ela mesma assumiu a gestão da comunicação sem a orientação e presença semanal de membros da equipe do NCE-USP.

Os estudos de caso se basearão em:

- Visitas a algumas escolas que realizam produções radiofônicas e integram a amostragem da pesquisa;

- Entrevistas com perguntas abertas para contextualizar o uso do rádio na escola (de modo a contemplar as especificidades de cada unidade escolar); 
- Questionários fechados seguindo a escala Likert (com graus de concordância/discordância) com perguntas sobre o comportamento e a participação dos alunos que passaram a se envolver com as práticas educomunicativas de produção radiofônica;

- Entrevista com o coordenador do projeto "Educomunicação pelas Ondas do Rádio” na Prefeitura de São Paulo durante o período da pesquisa.

Portanto, a pesquisa se propõe a analisar:

- De modo quantitativo: as produções radiofônicas realizadas ao longo do projeto “educom.rádio” ${ }^{15}$ com a mediação das equipes do NCE-USP;

- De modo qualitativo: o processo de produção radiofônica nas escolas municipais que deram continuidade às práticas educomunicativas após o curso do “educom.rádio”.

15 - Muitas das produções radiofônicas realizadas ao longo do projeto “educom.rádio” estão armazenadas no site do projeto e podem ser acessadas pelo www.usp.br/educomradio no link “produções”. Há pelo menos um programa de rádio de cada uma das 455 EMEFs participantes. 


\section{Capítulo 1}

\section{A inter-relação Comunicação/Educação: das novas linguagens e tecnologias à contextualização política de um novo campo de estudo}

\section{1 - O avanço tecnológico e as mudanças na sociedade}

Cada vez mais nos últimos anos as tecnologias de informação e comunicação vêm desempenhando papel fundamental na configuração da sociedade e da cultura. Desde nossos antepassados caçadores que pintavam figuras nas paredes das cavernas até os dias atuais a tecnologia transforma o ser humano. Hoje, desde a infância, as tecnologias já aparecem integradas às nossas vidas, sendo utilizadas de forma tão natural que muitas vezes só nos damos conta delas quando falham (aparelhos que queimam, por exemplo) ou temporariamente desaparecem (como durante os momentos de falta de energia elétrica). Pensemos nos impactos que suscitaram na história da humanidade a sucessão de tecnologias que propiciaram novas formas de comunicação por meio da prensa, do telefone, do rádio, da TV, da Internet, etc. A era da velocidade eletrônica transformou o que entendíamos como espaço, distância e tempo levando ao que o sociólogo brasileiro Renato Ortiz denomina de “desterritorialização do sujeito”.

A onipresença dos meios de comunicação de massa na segunda metade do século XX e início do século XXI, disponíveis de forma instantânea, influenciou a produção de sentidos e a indução de ideologias, acarretando mudanças nas formas de agir e compreender tanto em nível individual quanto coletivo. 
As novidades tecnológicas e digitais possibilitam uma linguagem comum para o tratamento de dados, textos, sons, fotos e vídeos, rompendo, segundo o pesquisador Martín-Barbero $^{16}$, com a hegemonia racionalista do dualismo que opunha o inteligível ao sensível/emocional, a razão à imaginação, a ciência à arte, a cultura à técnica e o livro aos meios audiovisuais. A revolução tecnológica deixou de ser uma questão de meios para se tornar uma questão de fins.

De acordo com o pesquisador brasileiro Mauro Wilton de Sousa, a humanidade já passou por três idades da linguagem. A primeira foi a da oralidade, mediada pela palavra (inicialmente apenas oral e, depois, também na forma escrita). Nos últimos dois séculos, o ser humano conviveu com a imagem eletrônica, primeiramente com a fotografia (imagem fixa) e posteriormente com o cinema e a televisão (imagem em movimento), sendo que a TV ainda transmite a sensação de temporalidade. Hoje, porém, já estamos diante de um terceiro momento, de uma terceira linguagem, uma terceira instrumentação. Já não é mais a palavra, já não é mais a imagem. Nós já estamos dentro do que se chama de multimídia ${ }^{17}$.

Paul Levinson ${ }^{18}$, estudioso da área de mídia da Universidade Fordham, em Nova York, classifica a evolução das tecnologias de comunicação em três estágios:

1. no primeiro estágio, a espécie humana se encontrava numa comunidade comunicativa em que todas as características do mundo natural estavam presentes,

\footnotetext{
16 - Jesús MARTÍN-BARBERO. La Educación desde la Comunicación. Grupo Editorial Norma, Buenos Aires, 2002

17 - Mauro Wilton SOUSA. Novas linguagens. São Paulo, Editora Salesiana, 2001, p.12

18 - Paul LEVINSON. “Computer Conferencing in the Context of the Evolutions of Media”. In Harasim, L.M. Online Education. Perspectives on a New Environment. New York, Praeger Press, 1990, p. 3-14.
} 
mas a comunicação se reduzida aos limites físicos e biológicos da visão, do ouvido e da memória.

2. no segundo estágio, para superar os limites biológicos, o ser humano desenvolve novas tecnologias (como a escrita, que preservava o dados e informações mais além das limitações da memória humana e permitia transmitir o "saber" a distância). Renunciava-se ao entorno da comunicação natural, dos sentidos (como o "silêncio" do texto, ou a falta de interatividade do livro, como se diz na terminologia moderna).

3. no terceiro estágio, os novos meios eletrônicos (primeiramente os analógicos e posteriormente os digitais) não só estendem as possibilidades de comunicação muito além de nossos limites biológicos, como também recuperam elementos e características da etapa pré-tecnológica anterior à da escrita (interatividade entre emissor e receptor, tempo real, uso direto dos sentidos, etc.). A realidade pode ser vista e sentida de qualquer lugar, ao mesmo tempo em que se sucede em outra parte do planeta ou em que é registrada para a posteridade.

Ao longo dos últimos anos, diversas correntes teóricas e muitos autores anunciam e alertam para a chegada e consolidação da proclamada Sociedade da Informação, como resultante de um conjunto de transformações econômicas, políticas e sociais que alteraram a base da sociedade. As novas tecnologias de informação e comunicação (também chamadas de TICs) rapidamente se infiltraram em todas as áreas da vida moderna transformando nossas formas de trabalhar, de nos divertirmos, de nos relacionarmos e de aprender. Seus efeitos ultrapassam as áreas das telecomunicações provocando mudanças na estrutura econômica, profissional, social, jurídica e política. O avanço tecnológico alterou 
não só as formas de aquisição de informações como também as possibilidades de manipulá-las, armazená-las e distribuí-las.

O rápido desenvolvimento das novas tecnologias de comunicação e informação aponta principalmente para a modificação na elaboração e distribuição de informação; a criação de novas formas e possibilidades de expressão; e o desenvolvimento de novas extensões da informação capazes de fazer conviverem pequenas tribos dentro de uma grande aldeia global com aspectos transculturais com espaço para o local, o regional, o nacional e o internacional. A informação está se convertendo em produto valioso submetido a processos de geração e difusão industriais similares aos de outros tipos de produto.

O setor industrial que comercializa e apóia suas atividades econômicas na informação (os meios de comunicação de massa, as empresas de software, as do sistema financeiro, as de telecomunicações, as indústrias do lazer e entretenimento, etc...) está em crescimento, oferecendo cada vez mais produtos sofisticados e com novos serviços agregados (um celular, por exemplo, tem muitas funções extras além de telefonar e receber ligações). Crianças e jovens são, na maioria das vezes, o público-alvo dessa indústria em expansão.

Enquanto isso, a relação entre as novas tecnologias e o sistema educativo tem sido muitas vezes reduzida ao simples enfoque de que se trataria apenas de mais um ou outro meio entre os recursos que os docentes poderiam utilizar em seus aspectos didáticos, sem assumir e reconhecer que as novas tecnologias estão modificando a sociedade para a qual estão educando crianças e jovens.

É necessário que professores e responsáveis pelas várias instâncias escolares pensem e redefinam qual é o papel da Educação atualmente e suas prioridades como educadores 
buscando compreender em que contexto estão inseridos seus alunos. É cada vez mais urgente a necessidade de se refletir sobre qual modelo de sociedade queremos construir e qual o papel das novas tecnologias nesse processo. Não se trata de uma visão ufanista das novas tecnologias e achar que por si só poderão melhorar o mundo, mas de reconhecer que elas estão aí e que precisamos discutir o que fazer com elas, como usá-las adequadamente de modo que possam até ajudar a inserir o educando numa Sociedade do Conhecimento em vez de mantê-lo apenas na Sociedade da Informação, ou seja, permitir que crianças e jovens estejam aptos a lidar com a grande quantidade de informações de modo a saber pesquisá-las, selecioná-las, organizá-las, relacioná-las, etc.

A aplicação prática dos múltiplos usos das novas tecnologias nos ambientes educativos não depende, no entanto, somente do desenvolvimento tecnológico, mas principalmente de decisões políticas e institucionais. A escola tem uma longa trajetória histórica e mantém uma série de práticas consolidadas, presas a uma estrutura arcaica e engessada, que são difíceis de serem modificadas a curto prazo.

Segundo Manuel Area Moreira, da Universidad de La Laguna (Espanha), o progresso de um país não depende só de seus recursos materiais ou de investimento de capitais, mas, cada vez mais, da qualidade de recursos humanos disponíveis, sendo necessário planejar e colocar em prática programas e ações formativas destinadas a facilitar o acesso ao conhecimento e às novas tecnologias a grandes setores de nossa sociedade: às crianças e aos jovens, aos profissionais, aos trabalhadores, aos dirigentes, etc... Sem recursos humanos qualificados - também poderíamos 
dizer que alfabetizados - no uso das Tecnologias de Informação e Comunicação (TIC) não poderá existir e avançar a sociedade da informação ${ }^{19}$.

Diante das inovações tecnológicas que invadiram a vida cotidiana nos vemos hoje em constante relação e interação com produtos oriundos do avanço da tecnologia, seja no trabalho, em casa ou na escola. Na escola? Nem tanto...

Entre os meios de comunicação de massa, a televisão transformou-se na principal fonte de informação da sociedade contemporânea. A linguagem audiovisual, predominantemente, influencia a visão de mundo das novas gerações. As formas de sentir e de atuar são orientadas pela mídia e, muitas vezes, aceitas como modelo. No entanto, como constata Maria Aparecida Baccega, professora da ECA/USP,

ocorre que, no mais das vezes, essas conquistas tecnológicas continuam fora da escola. Aí reside o grande perigo. Ao invés de estarmos lutando para que a comunicação que nos chega através dos meios seja efetivamente praticada como um direito social, estamos ainda brigando contra essa modalidade de comunicação ${ }^{20}$.

A educação formal se mostra lenta para acompanhar o ritmo das transformações da Sociedade da Informação e tem demonstrado pouca eficiência para interagir com o horizonte cultural de crianças e jovens e também com a perda de sua hegemonia como difusora e legitimadora do conhecimento. A escola tem se desenvolvido num mundo à parte da realidade exterior dos lazeres, dos prazeres, dos costumes e das mídias.

\footnotetext{
19 - Manuel Área MOREIRA. Problemas y retos ante las tecnologías digitales en la Sociedad de La Información. Disponível em http://webpages.ull.es/users/manarea/documento15.htm

20 - Maria Aparecida BACCEGA. "Comunicação na educação formal: processo de mudança”. In Revista Comunicação \& Educação (9), São Paulo, maio/ago 1997, p.8
} 
Hoje presenciamos a hegemonia da linguagem audiovisual sobre a tipográfica e constatamos que as condições de pensar e organizar a sociedade passam pela comunicação de massa que detém a hegemonia da construção e legitimação das representações sociais. Os meios de comunicação de massa passaram, muitas vezes, a substituir as instituições tradicionais (como a escola, o Estado...) no papel que elas deveriam desempenhar e a população recorre ao rádio e à televisão buscando obter aquilo que as instituições não lhe estariam proporcionando. A professora Marília Franco, da ECA-USP, constata que os meios audiovisuais continuam sendo consumidos largamente pelas pessoas, proporcionando um derrame de informação que, mesmo sem tratamento pedagógico, transforma-se em formação ${ }^{21}$.

Diante da onipresença midiática, Nestor Canclini, pesquisador argentino radicado no México, evidencia a necessidade de o sistema educativo não ignorar o mercado, o consumo e os meios de comunicação de massa que os atende. O autor defende a idéia de que uma revanche cultural $^{22}$ vem ocorrendo por meio dos receptores dos meios de massa e que o consumo deve ser assumido como exercício de cidadania. Neste sentido podemos estimular a transformação dos estudantes (vorazes consumidores das tecnologias de informação e comunicação) em cidadãos à medida que se apropriem dos mesmos mecanismos de informação e comunicação para estabelecerem o diálogo e exercitar suas formas de expressão visando a um mundo mais justo, igualitário, ético e socialmente responsável.

Sem cair numa visão extremamente pessimista ("tecnofobia”) ou positiva (“tecnoutopia”) a respeito dos recursos tecnológicos buscamos ressaltar a essência do

\footnotetext{
${ }^{21}$ - Marília FRANCO. "Linguagens audiovisuais e cidadania”. In Revista Comunicação \& Educação (9), São Paulo, maio/ago 1997, p.34

22 - Nestor Garcia CANCLINI. Consumidores e Cidadãos, conflitos multiculturais da globalização. Rio de Janeiro, Editora da UERJ, 1995
} 
pensamento do pesquisador francês Pierre Levy ${ }^{23}$, um dos teóricos mais respeitados nos estudos da relação tecnologia/sociedade, quando defende a idéia do homem agindo sobre a tecnologia e não da tecnologia agindo sobre o homem.

\section{2 - As novas tecnologias de comunicação no espaço escolar}

Como podemos perceber, a escola, nas últimas décadas, deixou de ser o único local para obtenção de informações e desenvolvimento do conhecimento tendo em vista que os meios de comunicação continuam seduzindo a sociedade e quase todos que os criticam também os utilizam cotidianamente. A maioria dos alunos passa mais tempo em contato com os meios de comunicação do que na escola com seus professores. Presentes em quase todos os lares, os meios de comunicação passaram a ser chamados de “escolas paralelas” pelo pesquisador mexicano Guillermo Orozco porque ensinam ser ter licença para isso.

Quando foi criada há alguns séculos a escola tinha como uma de suas principais funções disseminar a escrita e até hoje a avaliação do aprendizado dos estudantes é feita predominantemente pela linguagem verbal escrita, ferindo a bagagem cultural do aluno, que nasceu e está inserido em uma sociedade da comunicação generalizada, como define o

\footnotetext{
23 - Pierre LÉVY. Inteligência Coletiva: Por uma antropologia do ciberespaço. São Paulo, Edições Loyola, 1999
} 
filósofo italiano Gianni Vattimo ${ }^{24}$. Percebemos hoje que o sistema educativo encontra-se obsoleto e desatualizado perante o desenvolvimento tecnológico e o do próprio ser humano. A escola tem dificuldade para desenvolver outras linguagens com os alunos e segue rituais como ditado, redação e cópia enquanto os docentes repetem os roteiros dos livros didáticos e os alunos respondem exercícios escritos.

Em conferência no Fórum Mundial de Educação, em São Paulo, em 2004, o professor Ismar de Oliveira Soares, supervisor de projetos de Educomunicação do NCE-USP, afirmou que o que existe hoje é mais um grave problema na relação entre mídia e educação, do que um confronto entre "tecnologia e educação”. Falta uma cultura no espaço escolar para que se consolide uma relação apropriada da educação com a mídia devido à resistência, ou até mesmo preconceito, da maioria dos docentes em relação às novas linguagens trazidas pelo mundo das técnicas. Sem contar que há um certo receio dos professores em utilizar as mídias e constatar que seus próprios alunos podem ter mais informações, conhecimentos e familiaridade para manejá-las e apropriar-se dos diferentes recursos que estas oferecem. Na verdade, muitos professores concebem a escola apenas como um local de reprodução de conhecimento (desempenhando o que Paulo Freire definiu como educação bancária), apenas transmitindo informações, não exercendo papel de mediador, não permitindo a expressão comunicativa dos alunos por meio de diferentes linguagens, baseando a relação ensino-aprendizagem em uma cultura livresca e avaliando os estudantes quase exclusivamente pela escrita.

Com a “invasão” das mídias na vida de crianças e adolescentes, Pierre Babin e MarieFrance Kouloumdjian sugerem que se adote o que chamam de raciocínio estético ${ }^{25}$, pois as

\footnotetext{
24 - Gianni VATTIMO. A sociedade transparente. Relógio d’Água. Lisboa, 1992

25 - Pierre BABIN \& Marie-France KOULOUMDIJAN. Os novos modos de compreender. São Paulo, Ed. Paulinas, 1988
} 
instituições escolares durante muito tempo afastaram de si a imaginação e a afetividade enquanto os meios e produtos audiovisuais trabalham em harmonia com estes dois parceiros que podem ser muito importantes nos processos de ensino-aprendizagem.

Numa linha de raciocínio semelhante, Fernando Font ${ }^{26}$ avalia que a Modernidade cometeu um grave erro ao dividir o homem em “razão” e "sensibilidade”, obrigando o sistema de educação formal a optar pela hegemonia da “razão”. O filósofo mexicano defende a idéia de que é necessário recuperar a sensibilidade e buscar uma "nova razão" capaz de pensar as individualidades e a pluralidade. Font propõe a idéia de inteligência sentiente e acredita que o próprio ato de sentir converte-se em ato de aprender. Neste sentido, a adequada utilização dos meios audiovisuais pode propiciar aprendizado por meio de sentimentos, emoções e sensações.

Uma idéia muito divulgada é a de que há grandes diferenças e dissociações entre “aprender” e “divertir-se/entreter-se”, como se existisse uma oposição natural entre estes dois objetivos. Pierre Babin e Marie-France Kouloumdjian fazem um alerta: na era das mídias vamos deixar à escola apenas as categorias do dever e do aborrecido? É querer matá-l $a^{27}$.Segundo os autores franceses, o ser humano da civilização audiovisual eletrônica liga intimamente a sensação à compreensão e sem afetividade não há audiovisual. Na mesma direção, Martín-Barbero alerta que

os meios de comunicação e as tecnologias de informação significam para a escola em primeiro lugar isto: um desafio cultural, que torna visível a distância cada dia maior entre a cultura ensinada pelos professores e aquela outra

\footnotetext{
${ }^{26}$ - Fernando Fernandez FONT apud Ismar de Oliveira SOARES. A gestão da comunicação no espaço educativo (ou Os desafios da Era da Informação para o sistema educacional). Disponível em http://www.eca.usp.br/nucleos/nce/pdf/079.pdf Acessado em 08/01/2006

27 - Pierre BABIN \& Marie-France KOULOUMDJIAN. Os novos modos de compreender. Edições Paulinas, 1989, São Paulo, p.177
} 
aprendida pelos alunos... É apenas a partir da compreensão da tecnicidade midiática como dimensão estratégica da cultura que a escola pode inserir-se nos processos de mudanças que atravessam nossa sociedade ${ }^{28}$.

A idéia de compreensão da tecnicidade mediática descrita por Martín-Barbero pode ser comparada ao conceito de mediação tecnológica na educação proposto por Soares como uma das sub-áreas do campo autônomo da Educomunicação. Seguindo o mesmo raciocínio, o professor da ECA-USP Adilson Citelli destaca que

dentre as várias faces da crise vivida pela escola, uma revelou-se com grande evidência: o descompasso existente entre o estrito discurso didático pedagógico e as linguagens não institucionais escolares. Uma formalizando as ações na sala de aula, constituindo a natureza 'única e diferenciada' do discurso escolar; a outra pressionando 'de fora', existindo na fala dos alunos, tomando boa parte de seu tempo, circulando de forma subterrânea... A escola parece não reconhecer institucionalmente as linguagens, formas e meios que sugiram concorrência no trato do conhecimento ${ }^{29}$.

Revela-se aí um duplo desafio a ser superado: se parte do sistema formal de ensino percebe que as linguagens midiáticas também são capazes de proporcionar e estimular o acesso à informação e a produção de conhecimento, pode, presumivelmente, enxergar neles um concorrente. Por outro lado, se as instituições escolares não vislumbram o potencial dos meios audiovisuais e das chamadas “linguagens não-escolares” podem avaliar as tecnologias de informação e comunicação com preconceito, buscando alertar seus alunos

\footnotetext{
28 - Jesus MARTÍn-BARBERO. Heredando el futuro. Pensar la educación desde la comunicación. Nómadas. Bogotá: Fundación Universidad Central, 1996, p.19

29 - Adilson CITELLI. Aprender e ensinar com textos não escolares. São Paulo: Cortez, 1997 p.21
} 
para se protegerem dos "malefícios” da grande mídia, mantendo, assim, as linguagens midiáticas fora da escola.

De acordo com Pierre Babin e Marie-France Kouloumdjian, os meios tecnológicos modernos, a invasão das mídias e o acesso a aparelhos eletrônicos na vida cotidiana vêm modelando progressivamente outro comportamento intelectual e afetivo: presenciamos nos últimos anos a ascensão de um novo modo de ser e de pensar, de um novo modo de ser em sociedade ${ }^{30}$

Na cultura de Gutenberg, da imprensa escrita, dos livros e textos a disposição das informações é linear, hipotética e dedutiva. Já a cultura audiovisual traz a não-linearidade, o mosaico, a mixagem, a composição por flashes, a intuição, a afetividade e a imaginação (principalmente no rádio e produtos de áudio). A fala e as formas de agir e pensar dos jovens que já nasceram nessa cultura audiovisual estão cada vez mais afetadas pelas características dessa linguagem das mídias audiovisuais e, muitas vezes, se choca com a postura livresca e linear da escola.

O livro continuará sendo fundamental como peça-chave para o que Martín-Barbero ${ }^{31}$ chama de primeira alfabetização (que abre ao educando o mundo da escrita e da fonética) e serve de base para a segunda alfabetização pela qual os estudantes terão acesso a outras formas múltiplas de escrever englobando as possibilidades audiovisuais, textos eletrônicos e hipertextos.

Não se trata de entrar na polêmica de optar entre o livro "ou” o audiovisual. O que as novas pesquisas e experiências a respeito da relação Comunicação/Educação propõem é a

\footnotetext{
30 - Pierre BABIN \& Marie-France KOULOUMDJIAN. Os novos modos de compreender. Edições Paulinas, 1989, São Paulo

31 - MARTÍN-BARBERO, Jesus. La Educación desde la Comunicación. Grupo Editorial Norma, Buenos Aires, 2002, p.52
} 
escolha pelo livro "e” o audiovisual. Vale ressaltar que as novas correntes como a Educomunicação propõem muito mais do que a simples leitura crítica de um produto audiovisual ou sua utilização apenas para a ilustração de determinado assunto. A intenção é ir muito mais além, fazendo com que o audiovisual na escola potencialize as formas de expressão de criança e jovens e sua capacidade de comunicação com várias instâncias da escola e da sociedade.

Neste sentido é importante capacitar professores e alunos para utilizarem adequadamente os novos recursos tecnológicos de comunicação nos processos de ensinoaprendizagem e nas atividades que ampliem as possibilidades de expressão de crianças e jovens, utilizando a mídia em uma perspectiva pedagógica e aproveitando o fascínio e a sedução propiciados por outras linguagens como a audiovisual. Segundo o teórico mexicano Guillermo Orozco

enquanto na escola queremos produzir uma situação propícia para o ensinoaprendizagem, os meios de comunicação estão reproduzindo situações reais, que se não têm muito que ver com o ensino, têm a ver e muito com a facilitação da aprendizagem $^{32}$.

Trabalhar com as mídias na escola tornou-se uma necessidade. A ausência ou o uso inadequado dos meios de informação e comunicação no espaço escolar pode comprometer a eficácia dos sistemas de ensino-aprendizagem, fazendo com que a escola continue perdendo cada vez mais o papel de legitimadora do saber. Os educadores precisam se preparar para conhecer e utilizar os meios e as linguagens que os aproximem do mundo de seus alunos como ressaltam Eduardo Monteiro e Márcia Feldman: 32 - Guillermo OROZCO. “Professores e meios de comunicação: desafios, estereótipos”. In Revista
Comunicação \& Educação (10), São Paulo, set/dez 1997, p.60 
as linguagens, as tecnologias da comunicação são instrumentos que constroem o pensamento e as formas de diálogo com a realidade, sendo fundamentais para a constituição do indivíduo, das comunidades e da cidadania. Não são luxo ou alternativa educacional supérflua, mas direitos prioritários dos cidadãos que vivem na era da informação e do conhecimento. ${ }^{33}$

O alerta de que essas tecnologias de comunicação não devem ser apenas luxo ou algo supérfluo é pertinente, pois nos anos 90 muitas instituições escolares (especialmente da rede privada) introduziram o computador mais como uma estratégia de marketing e de divulgação do que necessariamente como uma nova possibilidade pedagógica. Aproveitaram a euforia de modernização para associar a chegada das novas tecnologias de informação à sensação de que a introdução dos novos meios já proporcionaria por si só uma mudança didático-pedagógica, uma (re)evolução no sistema de ensino-aprendizagem. Esta tendência foi denominada por alguns especialistas como "marketing educativo".

O uso desses computadores durante algum tempo restringiu-se em muitos casos apenas à aprendizagem técnica de sistemas operacionais, programas e softwares, deixando de lado a criação e expressão dos estudantes. Como alerta o pesquisador uruguaio Mario Kaplún, no que diz respeito ao emprego de meios na educação, bem-vindos sejam desde que sejam aplicados crítica e criativamente, a serviço de um projeto pedagógico, ultrapassando a mera racionalidade tecnológica; como meios de comunicação e não de simples retransmissão; como promotores do diálogo e da

\footnotetext{
33 - Eduardo MONTEIRO e Márcia FELDMAN. "Mídia-educação:formando cidadãos da era da informação". In Revista Pátio, n.9, maio/jul. 1999 apud Ismar de Oliveira SOARES. "Metodologias da educação para comunicação e gestão comunicativa no Brasil e na América Latina” In Maria Aparecida BACCEGA, Gestão de processos comunicacionais, São Paulo-SP, Atlas, 2002, p.118
} 
participação; para gerar e potenciar novos emissores...enfim, não meios que falam e sim meios para falar $^{34}$.

No entanto, na maioria das faculdades de Pedagogia, a tecnologia é considerada apenas “auxiliar”. Soares sugere algumas questões que podem explicar a resistência das escolas em permitir aos estudantes o acesso às novas mídias e tecnologias:

receio de permitir que os alunos se percam em meio a tanta informação, impossível de ser controlada pelos professores e pais? Ou receio de que os alunos passem a navegar num mundo de informação que reduzirá a importância dos mestres como fonte de informação? Ou mesmo simples comodismo e dificuldade em conviver com o novo $?^{35}$.

Acrescentando alguns motivos e hipóteses ao levantamento dos professores Julio Cabero, Ana Duarte e Julio Barroso, das universidades espanholas de Sevilha, Huelva e Extremadura no artigo "La piedra angular para la incorporación de los medios audiovisuales, informáticos y nuevas tecnologías en los contextos educativos: la formación y el perfeccionamiento del profesorado" 36 podemos apontar como principais causas para a escassa utilização das tecnologias de informação e comunicação no espaço escolar problemas de:

\footnotetext{
34 - Mario KAPLÚN. Processos educativos e canais de comunicação. In Revista Comunicação \& Educação num. 14, São Paulo, jan/abril 1999, p. 74

${ }^{35}$ - Ismar de Oliveira SOARES. "Metodologias da educação para comunicação e gestão comunicativa no Brasil e na América Latina”. In: BACCEGA, Maria Aparecida, Gestão de processos comunicacionais, São Paulo-SP, Atlas, 2002, p.124

${ }^{36}$ - Texto disponível em http://www.uib.es/depart/gte/edutec-e/revelec8/revelec8.html, acessado em $28 / 05 / 2005$
} 
a) Formação:

- Falta ou inadequação de capacitação para usar os recursos disponíveis e conhecer suas potencialidades;

- Limitação da formação do corpo docente para utilizar as novas tecnologias;

- Tendência das atividades de formação docente para uma capacitação meramente instrumental;

- Falta de tempo do corpo docente para aprofundar seus conhecimentos sobre tecnologias e meios de comunicação, bem como para se dedicar à pesquisa e ao planejamento de novas propostas de utilização dos meios audiovisuais;

- Escassez de estudos e publicações sobre o uso das tecnologias de comunicação e informação na escola.

b) Prática:

- Atitudes de desconfiança, receio e até preconceito por parte dos educadores em relação aos meios de comunicação;

- Limitação de informações práticas sobre a aquisição e o uso dos meios no contexto educativo visando à expressão do educando;

- Falta de treinamentos práticos e de capacitações técnicas básicas;

- Tendência atual de que cada vez mais os materiais de ensino não convencionais devem ser produzidos por profissionais das respectivas áreas.

c) Gestão: 
- Falta de equipamentos, meios tecnológicos, hardwares e softwares nos espaços educativos;

- Custos e burocracias para compras, licitações e manutenção de equipamentos;

- Problemas de infra-estrutrura para viabilização de espaços adequados para a produção midiática na escola;

- “Imobilismo” que tende a se desenvolver na escola;

- Sensação de trabalho adicional para o professor nos momentos de criação e planejamento de produção ou uso de materiais de ensino-aprendizagem que utilizem outras linguagens;

- Problemas e dificuldades de comunicação interna entre as diversas instâncias das instituições educativas;

- Ausência das propostas e das atividades de expressão comunicativa no Projeto Político Pedagógico da escola.

Diante destes possíveis entraves, Marília Franco propõe uma mudança de atitude dos educadores:

Para o professor poder formar sua cidadania audiovisual docente é preciso discutir os medos e preconceitos, reconhecer suas competências enquanto espectador/telespectador e pôr em foco essa pessoa social que gosta de TV e de cinema e o profissional-professor que pode levar essa competência para a sala de aula como apoio à atividade didática ${ }^{37}$.

\footnotetext{
37 - Marília FRANCO. “Linguagens audiovisuais e cidadania”. In Revista Comunicação \& Educação (9), São
} Paulo, maio/ago 1997, p. 33 
Nesse contexto de dificuldades de relacionamento com as novas tecnologias de comunicação e informação, o educador norte-americano Marc Prensky ${ }^{38}$ ressalta o “choque de gerações”, classificando pais e professores como imigrantes e filhos e estudantes como nativos do mundo digital. Criticando duramente a postura do corpo docente, o educador adverte que as escolas continuam ensinando o "velho mundo" e alerta:

fora da escola, há milhares de coisas que as crianças gostam e são estimuladas a fazer, e na escola são estimuladas a se aquietar - incluindo aí aquietar a mente... Numa época em que as crianças sabem que a tecnologia permite que ultrapassem o conhecimento de seus professores e viabiliza o acesso a programas individualizados, ainda se prendem os alunos como gado dentro de classes, ouvindo palestra e depois regurgitando informações em provas. Se os educadores saíssem desse caminho marcado, nossas crianças poderiam redesenhar a escola e a educação do século XXI $I^{39}$.

Opondo-se à visão daqueles que acreditam na tecnologia como solução mágica para atualizar a instituição escolar com o contexto sócio-cultural do educando e resolver as deficiências dos modelos de ensino-aprendizagem é importante ressaltar que não existe um "super-meio" capaz de solucionar, por si só, os problemas da escola, garantindo mais qualidade ao ensino e podendo ser utilizado em todas as aulas da mesma forma. A simples utilização de algum meio de comunicação na escola não garante eficácia no processo de aprendizagem.

É importante reconhecer que não há meios de comunicação melhores ou piores do que outros, como também ter ciência de que em função de muitas variáveis (características dos

\footnotetext{
38 - JORNAL FOLHA DE S. PAULO. Crianças devem redesenhar a escola, Revista da Folha, p.12, São Paulo, 05/02/2006

39 - idem
} 
alunos, estratégia didática, conteúdos curriculares ou extra-curriculares, etc) um determinado meio (e sua linguagem) pode se mostrar mais eficaz para determinados objetivos do educador ou do aluno para criar situações específicas de ensino. O aprendizado não ocorre apenas em função do meio tecnológico. Depende diretamente da estratégia didática em que se planeja sua utilização e da influência dos contextos social e cultural daqueles que se utilizam dele. Portanto é imprescindível conhecer as principais características e especificidades de cada linguagem para levá-las em consideração no momento do planejamento das atividades.

Em alguns casos já se sabe, de antemão, qual será o meio tecnológico disponível e, aí, se pensa nas melhores formas de usá-lo; e, em outros casos, primeiramente surgem as idéias de atividades para depois encontrar o meio mais eficaz para desenvolver as ações propostas. Muitas das atividades que utilizam as linguagens dos meios de comunicação podem ser não só multidisciplinares (envolvendo conhecimentos de mais de uma disciplina da grade curricular) como também multimídias (utilizando mais de uma linguagem e de um recurso tecnológico) enriquecendo e potencializando as atividades, inclusive desenvolvendo habilidades para abordar determinado tema de diferentes formas de acordo com a linguagem em questão. As ações que envolvem mais de uma “mídia” exigem, geralmente, mais atenção ao planejamento, à organização e à gestão participativa, podendo constituir-se em mais produtos finais e, também, num processo mais enriquecedor de criação, produção e avaliação.

Mas de nada adianta o educador conhecer profundamente as características de cada meio tecnológico e sua respectiva linguagem, se ele não souber qual pode ser a posição e a participação do educando na relação com as novas tecnologias em âmbito escolar. Para se adequar os objetivos e métodos da chamada “educação formal” ao atual contexto da 
Sociedade da Informação é necessário redefinir a intencionalidade das ações educativas, os modos de atuação do corpo docente e, conseqüentemente, os processos de ensinoaprendizagem. Os modelos formativos vigentes nas últimas décadas nos quais o educando tenta memorizar e armazenar dados e informações se mostram ultrapassados já que as atuais tecnologias são capazes de guardar quantidades muito superiores de dados e de informações do que o cérebro humano. O desafio atual que se coloca à educação é converter o educando em protagonista das ações de aprendizagem, permitindo que o aluno disponha de autonomia e controle sobre seu próprio processo de aprender a aprender.

Pierre Babin e Marie-France Kouloumdjian ${ }^{40}$ entendem que a escola precisa rever seu papel e fazem uma analogia definindo que em vez de uma escola-loja os estudantes deveriam ter uma escola-mesa. Ou seja, a escola poderia ser um local onde não se viesse em primeiro lugar para aprender coisas, mas para aprender a ligação que as coisas têm com a ação e com a sabedoria de viver. Em vez de uma escola-loja para consumir o saber, propõem uma escola-mesa: mesa sobre a qual se coloca junto o que se aprendeu, a fim de ligar, isto é, completar, relativizar, criticar e confrontar o aprendido com a sociedade e a ação.

Neste sentido, entendemos que a comunicação e os novos meios tecnológicos desempenham papel fundamental para o aprendizado na escola-mesa por propiciar, se bem utilizados, que os estudantes aprimorem suas formas de expressão, adotando uma postura ativa, capaz de avaliar e reavaliar dados e informações, transformando-os em conhecimentos e possam compartilhar suas práticas, idéias e divergências por meio do diálogo, não só com docentes, como com outros alunos e com a comunidade escolar.

\footnotetext{
40 - Pierre BABIN \& Marie-France KOULOUMDJIAN. Os novos modos de compreender. Edições Paulinas, 1989, São Paulo, p.150
} 
Educar para e pela comunicação passa a ser uma das prioridades na Sociedade da Informação.

Nesse cenário, vale ressaltar que o mais importante não é reter na memória todos os dados e informações, mas saber buscar, selecionar e analisar informações em diferentes fontes. A questão fundamental não reside na capacidade de memorização, mas nos processos de reflexão e no uso crítico e consciente dos variados recursos de informação e comunicação, seja impresso, digital ou audiovisual.

A oportunidade de qualquer cidadão comum, até então receptor das mensagens dos meios de massa, poder tornar-se emissor de conteúdo é conseqüência, entre outros fatores, do advento da Internet e dos recentes e rápidos processos de miniaturização e barateamento dos equipamentos de gravação e edição que evoluíram tecnologicamente para a qualidade digital. Ou seja, vivenciamos uma convergência de interesses: melhor qualidade técnica, maior facilidade de manuseio e transporte, maior facilidade de compra e aquisição devido à redução de custos. Vale ressaltar ainda que estão cada vez menos complexas as possibilidades de integrar projetos, produtos e mídias, formando redes de comunicação que podem potencializar os resultados esperados, ampliar o alcance, a divulgação e a disponibilização das diversas formas de expressão, dar voz a guetos, grupos e tribos, contribuindo para a melhoria da gestão da comunicação no espaço escolar.

Ciente de seu papel, a escola deve reconhecer que:

- fora dela existem outras fontes de informação que de forma mais prazerosa, motivadora, agradável e dinâmica são capazes de seduzir crianças e jovens nos atos de aprender, conhecer, viver e sentir;

- muitas pesquisas apontam que, ao longo de sua vida escolar, o aluno passa mais horas exposto aos meios de comunicação do que dentro da escola. 
O esforço para uma adequada atualização da escola a fim de reduzir e eliminar o descompasso e atraso com a Sociedade da Informação implica em um esforço para incorporar as mais variadas linguagens midiáticas (não só as mais recentes relacionadas à informática), mas também as outras que há décadas estão presentes na vida cotidiana (como o rádio) e que ainda não foram assimiladas por instâncias escolares que não perceberam seu grande potencial didático-pedagógico.

\section{3 - Comunicação e Educação: inimigas, vizinhas, irmãs? O que dizem as teorias?}

Para fazer uma abordagem epistemológica e teórica das relações entre Comunicação e Educação, precisamos, antes de mais nada, compreender o que podemos entender destas duas grandes áreas do saber humano. No âmbito desta pesquisa temos tratado "Educação" como processos, ações, atividades e projetos de ensino-aprendizagem que ocorrem na unidade escolar, no sistema de ensino público e particular. Se o termo “Educação” pode ser facilmente associado a "escola” e não permite muitas interpretações diferentes, o mesmo não ocorre com o termo “Comunicação”, capaz de adquirir diferentes significados principalmente após o desenvolvimento dos meios de massa. 
Segundo o argentino Jorge Huergo ${ }^{41}$, o termo “comunicação” vem do latim “communis” e significa “tornar comum”. Como verbo, apresenta dois sentidos principais:

- transitivo: significa transmitir, informar, persuadir, divulgar. Está relacionado ao poder, pois um fala e o outro escuta, um transmite e o outro é o simples destinatário da mensagem. Só um experimenta o processo de conhecimento e o outro é ignorado do processo (sendo que este depende do enunciatário para ter acesso ao saber). Trata-se de uma relação vertical, do saber ligado ao poder. Esse sentido de comunicar foi denominado de “alienação da ignorância” pelo educador brasileiro Paulo Freire porque o indivíduo que recebe a mensagem não pode ter o processo de conhecimento sem a “doação” daquele que detém o saber.

- intransitivo: comunicar é entendido no sentido de comunicar-se, partilhar, dialogar. Huergo deixa claro que a comunicação entre iguais raramente é simétrica e que o ato de dialogar deve ser entendido mais como "encontro" do que como "acordo". Afirma que este sentido de comunicação articula-se com a idéia do filósofo Jürgen Habermas sobre uma possível “comunidade ideal de comunicação” que no livro “Teoria da Ação Comunicativa” defende a idéia de comunicação como uma condição da vida social. A comunicação é um modo de agir, um comportamento, uma expressão humana observável e identificável visando ao entendimento mútuo.

O signo “comunicação” apresenta, portanto, uma ambigüidade de significados: o de transmissão (unidirecional) e o de interação (bidirecional ou multidirecional). Além de estudar e analisar a comunicação "transitiva” (como a que se costuma atribuir aos meios de massa) também é importante, principalmente em âmbito escolar (ou em qualquer outra

41 - Jorge HUERGO. La popularización de la ciencia y la tecnología. Disponível em http://www.redpop.org/publicaciones/mainlapopularizacion.html, acessado em 02/07/2006 
instituição de socialização), refletir sobre as possibilidades da comunicação "intransitiva" proporcionada pelas redes interpessoais. Trata-se de compreender o papel fundamental da comunicação nos processos de ensino-aprendizagem para:

- questionar as atitudes verticalizadas;

- promover relações participativas e cidadãs visando mais ao conhecimento do que à informação;

- rediscutir o papel da própria escola bem como as funções e comportamentos dos agentes envolvidos nas diversas instâncias do sistema formal de ensino.

Antes de mergulharmos nas variadas possibilidades de críticas mútuas, convívios, aproximações e inter-relações entre Comunicação e Educação é fundamental conhecermos os principais aspectos dessas duas grandes áreas que num primeiro momento parecem dois mundos tão diferentes e antagônicos como podemos perceber neste breve levantamento de suas características e linguagens:

\begin{tabular}{|l|l|}
\hline \multicolumn{1}{|c|}{ Mundo da Educação Escolar } & \multicolumn{1}{c|}{ Mundo da Comunicação de Massa } \\
\hline $\begin{array}{l}\text { Concepção desenvolvida a partir do século } \\
\text { XVIII. }\end{array}$ & $\begin{array}{l}\text { Concepção desenvolvida a partir do século } \\
\text { XIX. }\end{array}$ \\
\hline $\begin{array}{l}\text { Função: transmitir normas, cultura e valores de } \\
\text { uma geração para outra, manter a ordem } \\
\text { estabelecida. }\end{array}$ & $\begin{array}{l}\text { Função: disponibilizar informações, entreter, } \\
\text { divulgar serviços e produtos. }\end{array}$ \\
\hline $\begin{array}{l}\text { Espaço local. } \\
\text { Regido por normas conhecidas. }\end{array}$ & $\begin{array}{l}\text { Sem espaço definido. Desterritorializado, } \\
\text { espaço planetário, global. }\end{array}$ \\
\hline $\begin{array}{l}\text { população não sabe quem são ou não tem } \\
\text { acesso a eles). }\end{array}$ \\
\hline
\end{tabular}




\begin{tabular}{|l|l|}
\hline Traduzem formas nacionais de poder. & Traduzem formas globais de poder. \\
\hline Pensamento lógico, geométrico. & $\begin{array}{l}\text { Pensamento fragmentado. Mosaico, } \\
\text { composição por flashes. }\end{array}$ \\
\hline Linear. & Não-linear. \\
\hline Indutivo. & Dedutivo. \\
\hline Livresco, escrito. & Sonoro, visual, audiovisual. \\
\hline Imagens e textos fixos. & Imagens e textos em movimento. \\
\hline Predomínio do racional. & Predomínio do emocional. \\
\hline $\begin{array}{l}\text { Participação do } \\
\text { “obrigatoriedade”. }\end{array}$ & $\begin{array}{l}\text { Participação do educando por interesse, } \\
\text { vontade, prazer, fruição. }\end{array}$ \\
\hline $\begin{array}{l}\text { Disponível para o educando durante cerca de de } \\
\text { 200 dias por ano, algumas horas por dia. }\end{array}$ & $\begin{array}{l}\text { Disponível para o educando durante 365 dias } \\
\text { por ano, 24 horas por dia. }\end{array}$ \\
\hline
\end{tabular}

Para analisarmos a introdução e o uso dos meios e linguagens da comunicação em âmbito escolar é importante realizarmos um estudo epistemológico da inter-relação Comunicação/Educação de modo a buscar conhecer um panorama geral da aproximação entre estas duas áreas do saber, desses dois campos de estudo. Essa aproximação ou relação tem presença marcante entre muitos estudiosos do cenário latino-americano nos quais podemos encontrar desde teorias que apontam os dois campos como indissociáveis e historicamente divididos até a proposição de um novo campo de estudo.

Instituições de ensino superior têm dificuldades de romper certas barreiras epistemológicas, segmentando e departamentalizando áreas que teriam muito a contribuir entre si na realização de abordagens e estudos multidisciplinares e, melhor ainda, transdisciplinares. No caso da USP, a maior universidade pública do país, constatamos que a Faculdade de Educação (FE-USP) que dificilmente “dialoga” com a Escola de Comunicações e Artes (ECA-USP). Enquanto cursos de Pedagogia e faculdades de Educação continuam quase sempre separados física, burocrática e institucionalmente dos 
cursos e faculdades de Comunicação Social, muitas classificações, divisões, junções já foram propostas por estudiosos que procuraram analisar como a sociedade tem tentado ou evitado relacionar os dois campos historicamente definidos.

Pensadores como Carlos Valderrama (Colômbia), Francisco Sierra (Espanha), Guillermo Orozco (México), Jorge Huergo (Argentina), Ismar de Oliveira Soares (Brasil), Jesús Martín-Barbero (espanhol radicado na Colômbia), Mario Kaplún (Uruguai) e Paulo Freire (Brasil) são nomes que não poderiam faltar para a construção desse breve panorama que mostra o grande leque de possibilidades de relação entre os dois campos.

A inter-relação Comunicação/Educação apontou ao longo da segunda metade do século XX duas tendências principais:

- “Media Literacy": alfabetização audiovisual a fim de promover o adequado consumo dos meios de comunicação de massa. Decorrente de problemas de ordem antropológica e cultural situa-se entre o conflito e a convivência com um sistema de meios de massa que possuem objetivos “divergentes” das propostas formais da educação. Analisava a interação entre as TICs e os jovens;

- “Information Literacy": uso de meios tecnológicos em espaços educativos. Decorrente de problemas de natureza operacional com implicações culturais e econômicas. Estudava a interação entre as TICs e os sistemas educativos.

Nos Estados Unidos, por exemplo, é possível identificar três fases principais no desenvolvimento da área de “Media Literacy” nas últimas décadas do século XX, segundo Ismar de Oliveira Soares ${ }^{42}$ :

\footnotetext{
42 - SOARES, Ismar de Oliveira. Educomunicación: comunicación y Tecnología de la Información en la reforma de la enseñanza americana, in Dia-Logos de FELAFACS, n. 59-60, outubro de 2000, p. 137-152
} 


\begin{tabular}{|c|c|c|}
\hline $\begin{array}{l}\text { Fase Defensiva } \\
\text { (“deficit model”) }\end{array}$ & $\begin{array}{c}\text { Fase de } \\
\text { Desautorização/Embotamento }\end{array}$ & $\begin{array}{l}\text { Fase de Recuperação } \\
\text { (“acquisiton model”) }\end{array}$ \\
\hline Anos 70 & Anos 80 & 90 \\
\hline Caráter & Caráte & $\begin{array}{c}\text { Caráter construtivista e } \\
\text { multiculturalista }\end{array}$ \\
\hline $\begin{array}{l}\text { Responsabilizava os meios de } \\
\text { comunicação (especialmente } \\
\text { a TV) pela violência entre os } \\
\text { jovens e suas dificuldades de } \\
\text { aprendizagem. }\end{array}$ & $\begin{array}{l}\text { Maior tolerância em relação aos } \\
\text { meios de massa, preocupação com } \\
\text { os efeitos diretos das drogas e da } \\
\text { delinqüência juvenil. }\end{array}$ & $\begin{array}{c}\text { Buscava desenvolver } \\
\text { habilidades expressivas pela } \\
\text { comunicação visando à leitura } \\
\text { crítica dos meios. }\end{array}$ \\
\hline $\begin{array}{c}\text { Proteção dos receptores } \\
\text { contra os efeitos dos meios. }\end{array}$ & $\begin{array}{l}\text { Utilização de vídeos como } \\
\text { instrumento pedagógico. }\end{array}$ & $\begin{array}{l}\text { Análise e produção de } \\
\text { mensagens. }\end{array}$ \\
\hline
\end{tabular}

Ainda na linha do “Media Literacy” podemos diagnosticar que a leitura crítica ao longo do século XX mudava de foco conforme a teoria ou corrente:

- foco no emissor: Marxismo, Funcionalismo, teorias normativas e moralistas;

- foco na mensagem: Difusionismo e Semiologia;

- foco no receptor: Estudos Culturais, Medição e Estudos de Recepção.

Outro conceito muito difundido foi o de "Comunicação Educativa”. Começamos por Francisco Sierra $^{43}$ que propõe que nas últimas décadas a variedade de posições teóricas nesta área pode ser divida em duas linhas principais:

- a informacionista (instrumental): baseada tanto no "pensamento tecnocrático" da defesa de que o sistema formal de ensino deve distribuir o saber social (racionalidade instrumental) como no "pensamento tradicional”, segundo o qual o

43 - Francisco SIERRA, "Paradigmas y modelos teóricos de la comunicación educativa”. In Carlos VALDERRAMA, Comunicación-Educación, Coordinadas, abordajes y travesías. Universidad Central/DIUC, Bogotá, 2000 
sistema educativo seria o refúgio dos valores humanistas frente à cultura do espetáculo, do hedonismo e da fragmentação;

- a cultural (interpretativa): destaca a contextualização do local, dos meios, sistemas e recursos de informação e aprendizagem dando ênfase às necessidades, características e hábitos culturais dos grupos destinatários. Engloba a idéia de “educação participativa” na qual o receptor se converte em produtor de mensagens e também a capacitação para recepção crítica dos conteúdos dos meios de comunicação de massa.

Já para o uruguaio Mario Kaplún existem três modelos metodológicos de “comunicação educativa”:

- modelo bancário;

- modelo dos efeitos;

- modelo dialógico ou transformador.

O modelo bancário é considerado formal, rico em informação e pobre em ação, dando primazia ao saber sobre o fazer. A dinâmica de ensino-aprendizagem é predominantemente centrada no professor e quase nunca no aluno, que por sua vez constantemente decora ou memoriza informações. Trata-se do uso da racionalidade cartesiana, na qual prefere-se que o aluno se lembre da informação em vez de saber onde e como encontrá-la A relação professor-aluno é verticalizada e autoritária, tendo em vista que o sentido de educar é entendido como informar algo produzido, fechado e objetivo. Este modelo relega a leitura crítica em favor da acumulação quantitativa de informações e desconsidera a capacidade do sujeito de negociar e ressignificar sentidos, tratando-o como um receptáculo de 
informações, num processo em que as funções do professor se resumem a um caráter expositivo e controlador, sendo este capaz de vigiar e punir.

O modelo dos efeitos, segundo Kaplún, é inspirado na cibernética e integra ciências da informação com disciplinas de aprendizagem, visando à modernização do sistema de ensino. Este modelo delimita o campo da pedagogia a partir das definições da informática gerando o conceito de “Tecnologia Educativa”. Os sistemas audiovisuais e o computador podem ser usados como substitutos do professor em um processo unidirecional de ensino individualizado com modelização personalizada.

O modelo dialógico ou transformador é centrado no "processo" buscando gerar sentidos. Reconhece o papel do setor informativo na apreensão e contextualização da realidade e dá importância tanto à objetividade como às subjetividades. Propõe a organização de um sistema participativo e autônomo que inclui todas as modalidades de comunicação (individual, grupal, oral, escrita, transversal, etc...). A aprendizagem não é só questão de leitura, mas também de ver e ouvir. O professor informador é substituído pelo educador animador viabilizando um processo ativo de reconstrução contextualizada da aprendizagem pelos sujeitos educandos. O estudante não é visto como um receptáculo passivo e os consumidores passam da individualização à identificação grupal (tribos, bandas, etc...).

Para Francisco Sierra, essa divisão posposta por Kaplún carece de fundamentação teórica em relação à Teoria da Informação e à epistemologia. Sierra propõe três modelos metodológicos de Comunicação Educativa, juntando o "modelo bancário" e o "modelo dos efeitos” em uma só categoria que denomina de "modelo informacional” e acrescenta um paradigma que chama de “sociopráxico”. Eis a divisão proposta por Sierra:

- modelo informacional; 
- perspectiva culturalista;

- paradigma sociopráxico.

O modelo informacional apresenta uma teoria instrumental centrada na aplicação pedagógica dos meios e das tecnologias na qual a transmissão de informação se dá por um processo linear. Agrega as idéias da “educação bancária” e do “modelo dos efeitos” num conceito positivista de aprendizagem. A “educação bancária” é caracterizada pelo escasso vínculo comunitário, pela ênfase na perspectiva do emissor e por converter o aluno em mero leitor. O “modelo dos efeitos” produz uma formalização do comportamento, a programação docente tem objetivo instrucional, ocorre dispersão e fragmentação dos conteúdos enquanto se desenvolve a competitividade e a individualização do processo de aprendizagem.

A perspectiva culturalista sugere a aplicação das tecnologias e dos meios de informação, dando ênfase ao “processo”. Propõe a reflexão e o diálogo como processo de interação, abrindo espaço aos contextos locais de interpretação, à construção ativa de mensagens, ao manejo dos meios e tecnologias da informação e à construção cooperativa do saber, em detrimento da educação competitiva, num processo de interação grupal e de diálogo com a cultura e o entorno local. Sugere o desenvolvimento de visão crítica da recepção e dos processos de informação e reconhece o papel das novas tecnologias como instrumentos de investigação e de expressão social.

O paradigma sociopráxico visa à aplicação das novas tecnologias como forma de prática coletiva e de mobilização do conhecimento, utilizando os meios como pretexto para aprendizagem a partir das necessidades de desenvolvimento local. Prega uma educação dialógica, com a criação de redes sociais de interconexão e visão mais ampla de educação 
como prática política. É pensada não tanto para educar ou informar, mas para a transformação e modificação da realidade imediata. Os meios não são apenas espaço de expressão, mas também de análise social da comunidade.

Ainda na discussão das tecnologias de comunicação e informação no processo de ensino-aprendizagem, o mexicano Guillermo Orozco $^{44}$ critica o termo Educação a distância, ressaltando que ele é tão polissêmico quanto polêmico e muitas vezes acaba sendo utilizado apenas como oposição à “educação presencial”. Uma das principais críticas que se faz a este conceito diz respeito a quando é utilizado como no "modelo dos efeitos", concebendo que o conhecimento e os saberes estão concentrados em uma única fonte e o objetivo da EAD é aproximar o destinatário (distante fisicamente) para apropriação e/ou memorização dos saberes.

Quando defende que a EAD não pode ser definida apenas como contraposição à educação presencial, Orozco ${ }^{45}$ apresenta o conceito de Educação mediática, que segundo ele é a educação que usa os diversos meios e tecnologias de informação, em diferentes formatos e combinações, em diversas situações específicas de aprendizagem como presencial, semi-presencial e não-presencial.

A escola possui uma tradição de ser considerada a instituição responsável por transmitir o conhecimento sancionado pela sociedade e pelo Estado, modelo que Paulo Freire e Mario Kaplún denominam de “educação bancária”. Para Orozco, a educação a distância não deve enviar apenas conteúdo, mas um estímulo para facilitar a aprendizagem, com mensagem aberta de modo a propiciar a interação do usuário com esse conteúdo e com outros elementos de seu contexto sócio-cultural, realizando uma nova produção que tanto pode ser

\footnotetext{
44 - Guillermo OROZCO. “Elementos para uma política de educación mediática”. In Carlos VALDERRAMA, Comunicación-Educación, Coordinadas, abordajes y travesías. Universidad Central/DIUC, Bogotá, 2000

45 - ibidem
} 
uma reprodução do conteúdo transmitido, mas também pode se diferenciar muito do conteúdo original.

A partir da década de 80, convivemos com o conceito de Tecnologia educativa, que de acordo com Orozco se diferencia da EAD ao assumir que os meios e as tecnologias de informação potencializam o processo educativo em aula, pois agilizam, ampliam ou contextualizam os conteúdos. Para esta corrente, os meios poderiam ser utilizados para apoiar o ensino presencial, agilizando e melhorando a transmissão de informações. A corrente da "Tecnologia Educativa” assumia uma perspectiva somativa dos novos meios sem considerar explicitamente as diferentes linguagens e, segundo Orozco, não necessariamente implicou em avanço pedagógico, nem na compreensão do papel e do desafio das novas tecnologias.

Diante desse quadro, Orozco propõe como solução para a escola na Era da Informação a corrente da "Educação mediática", que se caracteriza pela realização de processos educativos “com”, “a partir” e "através” do uso dos meios impressos e audiovisuais e das tecnologias de informação. Podem incluir tanto as iniciativas da "Educação a distância" como as da "Tecnologia educativa”. Esta nova corrente defende a organização de estratégias de alfabetização múltipla em diversos meios e tecnologias empregados na produção, circulação e apropriação de saberes, visando a transcender a mera instrumentalidade e a entender que os meios não só transmitem, mas também podem determinar conteúdos e dar forma a eles.

Propõe-se um esforço integral para educar para e também com os meios de modo que se aprenda sobre os códigos audiovisuais e digitais, possibilitando que os educandos interajam com outros meios e se expressem através deles. O aluno, situado em seu contexto, é considerado um sujeito comunicativo, cultural, ativo, histórico, capaz de significar de 
várias maneiras sua apropriação dos conteúdos, capaz de negociá-los e produzir novas aprendizagens.

Para Orozco, a “alfabetização múltipla” é o eixo central de qualquer tipo de educação “pós-moderna”, idéia compartilhada por Martín-Barbero, para quem o desafio da escola é passar do "palimpsesto” para o "hipertexto". Neste modelo de educação, a intenção é permitir que o aluno possa “aprender a aprender” e desenvolva sua capacidade de associação, interpretação, síntese e seleção de informações.

Orozco aponta a necessidade de mudanças institucionais e pedagógicas para que os novos instrumentos realmente potencializem os benefícios esperados em vez de petrificar, com a “tecnificação” os tradicionais métodos "bancários”. É preciso convencer educadores de que se pode converter em educativo aquilo que não foi produzido com esta finalidade, utilizando partes da programação cotidiana comercial das emissoras de rádio e TV, bem como filmes, jornais, revistas e sites. E um dos primeiros passos para estas mudanças é reconhecer que a maior parte da aprendizagem se realiza (e tende a se realizar cada vez mais) fora das instituições educativas tradicionais.

O cruzamento teórico entre Comunicação e Educação tem se mostrado cada vez mais intenso tanto que em 2002, no livro “La Educación desde la Comunicación”, MartínBarbero aponta Paulo Freire (um educador) como autor da primeira teoria latino-americana de comunicação por ter vinculado o sentido da comunicação à geração de uma linguagem capaz de fazer o sujeito nomear o próprio mundo. Para o saudoso educador brasileiro, ensinar não significa transferir conhecimento, mas criar possibilidade para sua própria construção. Segundo Martín-Barbero,

a porta à Comunicação que nos abre Paulo Freire é basicamente sua estrutura dialógica, pois há comunicação quando a linguagem dá forma à conflitiva 
experiência de conviver quando se constitui em horizonte de reciprocidade de cada homem com os outros no mundo ${ }^{46}$.

Segundo Freire, a educação é comunicação, é diálogo, na medida em que não é transferência de saber, mas um encontro de sujeitos interlocutores que buscam a significação dos significados ${ }^{47}$. A comunicação é entendida como elemento que permite transformar o ser humano em sujeito de sua própria história, vivenciando uma relação baseada no diálogo que conduza ao desenvolvimento de consciência crítica.

O pesquisador Carlos Valderrama, organizador do livro “Comunicación-Educación, coordinadas, practicas y travesías” (resultante do Seminário Internacional sobre Comunicação e Educação, realizado em outubro de 1999, em Bogotá, na Colômbia), divide em três áreas os trabalhos realizados na interface entre Comunicação e Educação nos últimos anos:

1) Educação para a recepção: enquanto em países desenvolvidos como Canadá, Austrália e algumas nações européias a educação para os meios de massa faz parte do currículo de ensino, em países latino-americanos ela ainda não foi incorporada à educação formal. Os primeiros trabalhos de educação para a recepção se basearam no modelo linear “emissor - mensagem - receptor”.

1. a) Leitura crítica dos meios: consiste em desvendar a ideologia das mensagens transmitidas pelos meios, baseando-se nos níveis de análise da semiótica: o denotativo, conotativo e o ideológico. Vigorou nas décadas de 70 e 80 nos momentos de forte denúncia ao imperialismo ideológico dos Estados Unidos.

\footnotetext{
46 - Jesus MARTÍN-BARBERO. La Educación desde la Comunicación. Grupo Editorial Norma, Buenos Aires, 2002, p.30

47 - Paulo FREIRE. Extensão ou Comunicação. Editora Paz e Terra, Rio de Janeiro, 1979, p.69
} 
1. b) Recepção ativa: teve como um de seus principais representantes, o CENECA (Centro de Indagación y Expresión Cultural y Artística de Chile) e dava ênfase tanto à mensagem como à recepção visando a promover uma atitude reflexiva diante das mensagens. Segundo esta vertente, a informação não oferece um significado único e a significação não se restringe apenas ao processo de emissão ou à análise semiótica, mas é construída por um sujeito imerso em seu contexto sócio-cultural. Reconhece que não se deve recorrer apenas à análise dos discursos dos meios audiovisuais e à lógica racional, mas complementá-las com a lógica das emoções tendo em vista que os meios produzem e usam sentimentos.

1. c) “Media Literacy” ou alfabetização audiovisual: sustenta que os meios são criadores e mediadores das informações que circulam nas sociedades e que os cidadãos devem compreender as maneiras como a mídia representa a realidade. Propõe que a análise crítica de produtos audiovisuais seja acompanhada do desenvolvimento de competências e destrezas técnicas relacionadas à produção. Segundo Valderrama, busca conseguir uma fusão de criticismo prático e prática crítica ${ }^{48}$.

1. d) Educação das audiências: propõe mediante um esforço pedagógico modificar o resultado da interação com os meios de modo que esta experiência beneficie a própria audiência permitindo que seja mais crítica e seletiva. Utiliza o conceito de "mediações múltiplas”, assumindo que o processo de recepção é mediado por influências provenientes do contexto sócio-cultural do sujeito de modo que as mediações podem ser:

- cognitivas (racionais, emocionais);

- $\quad$ situacionais (momento de interação com a mensagem e com o meio);

48 - Carlos VALDERRAMA, Comunicación-Educación, Coordinadas, practicas y travesías, Bogotá, Colômbia, Universidad Central/DIUC, 2000, p.XII 
- institucionais (valores e normas transmitidos pela instituição em que se encontra o indivíduo como escola, família, igreja, partido político, etc.);

- estruturais (classe, gênero);

- culturais.

2) Comunicação na educação: estudou inicialmente as dinâmicas comunicativas das relações pedagógicas e dos processos de ensino-aprendizagem dentro e fora da escola. Traçou um paralelo da área da Comunicação com a da Educação adotando um modelo linear comparando o professor com o emissor, o saber com a mensagem, o aluno com o receptor. Tratava-se de uma visão transmissionista que dá ênfase aos conteúdos e propõe uma relação verticalizada e autoritária entre docente e aluno.

A corrente da Pedagogia da Comunicação trouxe críticas a este modelo, alegando que o receptor-estudante deveria ser visto como um sistema de transformação auto-estruturante e auto-construtivo ${ }^{49}$. Defende que a "pedagogia da comunicação" não deve ser apenas mais uma matéria curricular, mas serviria como uma disciplina crítica que atuaria como fundamento comunicativo da educação para satisfazer necessidades humanas, sociais e culturais.

As correntes teóricas da semiótica e dos estudos culturais também reagiram trazendo a proposta de que tanto emissor como receptor situam-se em culturas particulares, com simbologias e valores e que as relações comunicativas na escola estão diretamente relacionadas ao universo cultural da região e das comunidades.

49 - ibidem, p. XIII 
3) Educação e novas tecnologias: trouxe reflexões sobre o papel das novas tecnologias de informação e comunicação na sociedade, na cultura e na educação bem como sobre seus impactos nos processos cognitivos. A primeira “corrida do ouro” ocorreu em torno do conceito da informática educativa que inicialmente introduziu sistemas, programas e softwares na relação ensino-aprendizagem sem alterar, no entanto, os modelos pedagógicos e comunicativos tradicionais resultando mais em processos de "transmissão" e “reprodução” do que de “criação” ou “re-criação” e buscando controlar mais quantitativamente do que qualitativamente o rendimento dos estudantes. Esta corrente apresenta basicamente duas tendências:

3.a) estandardização da aprendizagem segundo os parâmetros racionalistas da lógica de produção do mercado e concentração dos objetivos na aprendizagem do uso de equipamentos e softwares.

3.b) ao contrário da anterior, busca aproveitar as potencialidades do desenvolvimento tecnológico para:

- permitir que o educando desenvolva a criatividade;

- propiciar o acesso e a expressão por meio de novas linguagens;

- utilizar as possibilidades interativas e a lógica dos hipertextos;

- vivenciar um processo pedagógico capaz de permitir que o aluno tenha uma postura mais ativa.

Duas importantes rupturas epistemológicas contribuíram para o avanço dos estudos da inter-relação Comunicação/Educação. A primeira delas diz respeito ao lugar do sujeito que antes era considerado passivo e indefeso frente aos meios de massa, preso a uma relação 
vertical e unidirecional e, depois, passou a ser entendido como um sujeito crítico, ativo, capaz de ressignificar mensagens e criar novos sentidos.

Com o avanço dos “estudos culturais”, os meios de comunicação passaram a ser vistos como veículos capazes de promover a discussão e a "negociação de sentidos”. Receptor e emissor são entendidos quase igualmente como atores das práticas sociais em que estão inseridos. Os espaços de atuação do sujeito são heterogêneos, fragmentados, diversificados, dando-lhe a condição de receptor ativo, receptor-produtor de significados em variadas situações individualmente ou coletivamente.

A segunda ruptura refere-se ao rompimento com a visão linear, programada e conteudística do sistema formal de Educação. De acordo com as propostas de uma sociedade educadora, qualquer local (e não apenas a escola) pode se tornar espaço de aprendizado. Além dos conteúdos previstos no currículo escolar, também se passou a compreender como papel da Educação propiciar que o educando aprenda a conhecer, a fazer, a viver e, finalmente, “aprenda a aprender e apreender”.

\section{4 - Comunicação/Educação: intersecção ou campo autônomo?}

O pesquisador argentino Jorge Huergo ${ }^{50}$ entende a relação Comunicação/Educação como uma área de intersecção, como uma confluência de perspectivas teóricas e de práticas sociais e profissionais com interesses distintos que pode ser atravessada por três tipos de

\footnotetext{
50 - Jorge HUERGO, “Comunicación/Educación: itinerarios transversales”. In Carlos VALDERRAMA. Comunicación-Educación, Coordinadas, abordajes y travesías. Universidad Central/DIUC, Bogotá, 2000
} 
relações: “instituições educativas e horizontes culturais”; “educação e meios de comunicação” e “educação e novas tecnologias”. Para Huergo, existe uma possibilidade transdisciplinar na inter-relação Comunicação/Educação com negociações tensas que não se configura em uma nova disciplina ou em um campo autônomo.

Huergo acredita que é necessário compreender os sentidos da cultura da mídia de massa e dos processos de comunicação na cultura. Destaca que nem toda comunicação é educação e nem toda educação é comunicação e alerta para o risco de se reduzir a Educação apenas às questões da escola (didático-pedagógicas). O pesquisador argentino ressalta que a racionalidade comunicativa e pedagógica deve primar sobre a racionalidade tecnológica valorizando o papel ativo das audiências como sujeitos de comunicação. O desafio, segundo ele, é o de construir espaços democráticos de comunicação para resistir e negociar com o poder hegemônico.

Para Martín-Barbero ${ }^{51}$, não é mais possível pensar a Educação sem basear o modelo escolar nas demandas da sociedade-rede e levando em conta que todos os espaços possam se tornar educativos. Ressalta que as práticas de aprendizagem precisam dar conta das mudanças da sociedade, abrindo-se a outras linguagens que se articulam ao cotidiano, tendo em vista que as tecnologias modificam os estatutos dos saberes, levando ao descentramento do livro e da leitura linear, enquanto a população se identifica e exerce sua vida pública cada vez mais através dos discursos, sons e imagens dos meios de comunicação e da mídia.

Martín-Barbero destaca que a crítica dos conteúdos continua sendo feita de forma instrumental para difusão do saber sem levar em conta as linguagens audiovisuais. Os

51 - Jesús MARTÍN-BARBERO. Heredando el futuro. Pensar la educación desde la comunicación. Nómadas. Bogotá: Fundación Universidad Central, 1996 
meios de massa são espaços decisivos de reconhecimento social e a escola precisa pensar menos nos efeitos ideológicos dos meios e mais no seu próprio ecossistema comunicativo.

Já o brasileiro Ismar de Oliveira Soares ${ }^{52}$, também utiliza o conceito de “ecossistema comunicativo” defendido por Martín-Barbero, porém, ao contrário de Huergo considera a inter-relação Comunicação/Educação como um novo campo de conhecimento, que está formado, tem autonomia e se encontra em processo de consolidação. Chamado de Educomunicação, o novo campo está estruturado como processo midiático, transdisciplinar e interdiscursivo. Baseia-se na comunicação dialógica e visa à formação de "ecossistemas comunicativos” nos espaços educativos.

Apesar de identificar alguns descompassos entre Comunicação e Educação (a primeira se mostra mais ágil em suas formas e procedimentos, fragmentada, não-linear, aberta à rápida absorção das inovações tecnológicas; enquanto a segunda mantém-se presa à ordem e ao Estado civilizador, enfraquecido e resistente às inovações tecnológicas), Soares acredita que estes descompassos são formais e não epistemológicos e propõe a interdiscursividade. Para ele, embora a Comunicação e a Educação possuam seus próprios discursos e objetos de estudo, com outras ciências, ganham outra especificidade no diálogo interdiscursivo.

Segundo Soares, a Educomunicação propõe o uso do potencial dialógico das novas tecnologias para ampliar a expressão de alunos, professores e membros da comunidade escolar. O pesquisador defende que a reforma do sistema educacional deve ser voltada para a conversão da escola em espaço de comunicação livre (e não guiada pela razão instrumental moderna), adotando a escuta do outro, o diálogo e a gestão participativa e democrática.

\footnotetext{
52 - Ismar de Oliveira SOARES. “Comunicação/Educação: a emergência de um novo campo e o perfil de seus profissionais”. In Revista Contato, ano 1, num. 2, Brasília, jan/mar 1999
} 
Para pensar e consolidar o campo da Educomunicação é necessário prever e planejar a transformação dos sujeitos e suas realidades sociais, intervir nos processos culturais, estabelecer um diálogo entre os saberes hegemônicos e contra-hegemônicos, reconhecer e rediscutir a importância da escola e das tecnologias na sociedade pós-moderna e, finalmente, propor que um dos principais papéis da escola seja a formação de sujeitos que aprendam, acima de tudo, a se comunicar, tornando-se cidadãos mais críticos, ativos, autônomos, responsáveis e criativos. Por meio da implantação de “ecossistemas comunicativos”, podemos possibilitar que crianças e jovens analisem e compreendam o papel da mídia e possam expressar-se por meio de diferentes linguagens colocando a relação Comunicação/Cidadania como eixo do processo didático-pedagógico.

No âmbito desta pesquisa, entendemos a Educomunicação como um campo que transcende a estrutura acadêmica tradicional, legitimando-se como uma demanda da sociedade contemporânea. Procuramos buscar uma sinergia na interdiscursividade Comunicação/Educação com o objetivo de superar e propor novas alternativas à obsolescência dos métodos da Educação e aos valores mercadológicos da Comunicação. 


\title{
Capítulo 2
}

\section{A Educomunicação e os fundamentos teóricos \\ do projeto "educom.rádio"}

\begin{abstract}
A expansão e a livre expressão dos indivíduos constituem nosso propósito ético e político para o planeta. Isso supõe ao mesmo tempo o desenvolvimento da relação indivíduo/sociedade, no sentido democrático e o aprimoramento da relação indivíduo/espécie, no sentido da realização da Humanidade $e^{53}$.
\end{abstract}

(Edgar Morin)

\section{1 - Educomunicação: a consolidação de uma teoria}

Após a análise das principais teorias que relacionam Comunicação, suas tecnologias e Educação e antes de detalharmos a concepção e o funcionamento do projeto “educom.rádio”, é importante aprofundarmos os fundamentos teóricos da Educomunicação incluindo seu caráter interdiscursivo e multirreferencial, suas áreas e a interdependência com decisões políticas e institucionais.

A Educomunicação é entendida como uma nova área de intervenção social definida pelo professor da ECA-USP, Ismar de Oliveira Soares, como

o conjunto de ações inerentes ao planejamento, implementação e avaliação de processos, programas e produtos destinados a criar e a

53 - Edgard MORIN. Os sete saberes necessários à Educação do Futuro. Ed. Cortez, 9.ed, São Paulo, 2000, p.114-115 
fortalecer ecossistemas comunicativos em espaços educativos presenciais ou virtuais (tais como escolas, centros culturais, emissoras de TV e rádio educativas, centros produtores de materiais educativos analógicos $e$ digitais, centros coordenadores de educação a distância ou "e-learning" $e$ outros...), assim como a melhorar o coeficiente comunicativo das ações educativas, incluindo as relacionadas ao uso dos recursos de informação no processo de aprendizagem ${ }^{54}$.

Soares $^{55}$ acrescenta ainda que esse conjunto de ações se caracteriza por algumas constâncias, tais como:

- Os atores: “a realidade das mediações culturais protagonizadas historicamente pelos sujeitos sociais";

- A razão de ser: “a intencionalidade educativa no uso da mídia”;

- A metodologia: “a ação colaborativa”;

- A meta: “o pleno exercício da liberdade de expressão dos atores sociais”.

Portanto, a Educomunicação se fundamenta a partir da teoria das mediações culturais, confrontando-se e opondo-se à perspectiva funcionalista e unidirecional das práticas sociais, culturais e comunicativas.

Para Soares, a Educomunicação não é uma sub-área nem da Comunicação nem da Educação, tendo em vista que se encontra na interface destes dois campos teóricos. Estamos, assim, diante de um grande esforço epistemológico e teórico, apoiado e legitimado por práticas culturais.

\footnotetext{
${ }^{54}$ - Ismar de Oliveira SOARES. "Educomunicação: as perspectivas do reconhecimento de um novo campo de intervenção social: o caso dos Estados Unidos”. In Eccos Revista Científica Uninove (v.2 n.2), dez 2000b, p.63

55 - Ismar de Oliveira SOARES. "Metodologias da educação para comunicação e gestão comunicativa no Brasil e na América Latina” In Maria Aparecida BACCEGA, Gestão de processos comunicacionais, São Paulo-SP, Atlas, 2002, p.115
} 
No início de 1999, no artigo em que foi apresentada, pela primeira vez, a idéia de um novo campo, Soares $^{56}$ ressalta que a Educomunicação não é por nós tomada na singularidade de uma nova disciplina, fechada em seus limites e que ela está inaugurando um novo paradigma discursivo transverso, constituído por conceitos transdisciplinares e que, por sua natureza relacional, estrutura-se de um modo processual, mediático, transdisciplinar e interdiscursivo.

Trata-se de uma posição, segundo Soares ${ }^{57}$, que se aproxima das idéias de pensadores latino-americanos como Martín-Barbero e Paulo Freire que vinculam "contexto sociocultural”, “comunicação” e “educação” como uma relação e não como uma área que deva ter seu objeto disputado.

Conforme foi apontado no capítulo anterior, Comunicação e Educação têm características e discursos específicos e muitas vezes divergentes. Neste sentido, Soares entende que o eixo estruturante da Educomunicação como novo campo se dá pela interdiscursividade, pela polifonia discursiva, pelo discurso transversal. Ao retomarmos os conceitos de Paulo Freire, um dos precursores da inter-relação Comunicação/Educação, chegaremos ao clássico "Extensão ou Comunicação" 58 em que o educador afirmava que os processos comunicativos se inseriam no ideal do agir pedagógico libertador entendendo o ser humano como um “ser de relações” e não só de contatos, que não estava apenas "no mundo”, mas “com o mundo”. Neste contexto, entendia a comunicação como componente do processo educativo transformador.

\footnotetext{
${ }^{56}$ - Ismar de Oliveira SOARES. “Comunicação/Educação: a emergência de um novo campo e o perfil de seus profissionais” In Contato - Revista Brasileira de Comunicação, Arte e Educação num 2, Brasília: Senado Federal, jan/mar 1999, p.27

57 - Idem, p.55

58 - FREIRE, Paulo. Extensão ou Comunicação. Editora Paz e Terra, Rio de Janeiro, 1979
} 


\begin{abstract}
Segundo Soares, a Educomunicação
absorve seus fundamentos dos tradicionais campos da educação, da comunicação e de outros campos das ciências sociais, superando, desta forma, as barreiras epistemológicas impostas pela visão iluminista e funcionalista de relações sociais que mantêm os tradicionais campos do saber isolados e incomunicáveis. Trata-se, na verdade, de uma perspectiva de análise e de articulação em permanente construção, e que leva em conta o contínuo processo de mudanças sociais e de avanços tecnológicos pelos quais passa o mundo contemporâneo ${ }^{59}$.
\end{abstract}

Neste mesmo sentido, podemos nos referenciar nos estudos do sociólogo francês Edgar Morin relativos aos conceitos de complexidade e transdisciplinaridade, quando discorre sobre os princípios do que denomina de "conhecimento pertinente” alertando que existe inadequação cada vez mais ampla, profunda e grave, entre, de um lado, os saberes desunidos, divididos, compartimentados e, de outro, as realidades ou problemas cada vez mais multidisciplinares, transversais, multidimensionais, globais e planetários ${ }^{60}$.

Em suas apresentações de contextualização e defesa da existência do novo campo, Soares faz questão de ressaltar que o NCE-USP não o inventou, mas apenas constatou que ele já se fazia presente em determinadas práticas da sociedade civil. O pesquisador destaca, ainda, que a Educomunicação deve ser compreendida como uma "meta” a ser alcançada

\footnotetext{
59 - Ismar de Oliveira SOARES. “Caminhos da Educomunicação na América Latina e nos Estados Unidos”. In Caminhos da Educomunicação, 2.ed, Editora Salesiana, São Paulo, 2003, p.44

60 - Edgard MORIN. Os sete saberes necessários à Educação do Futuro. Ed. Cortez, 9.ed, São Paulo, 2000, p.36
} 
mantendo-se em constante evolução e dificilmente atingindo $100 \%$ dos objetivos que seus promotores se propõem a alcançar, levando em conta que nem sempre estão presentes todas as condições necessárias para que uma ação possa ser caracterizada como educomunicativa como, por exemplo, uma sintonia perfeita, em termos teóricos e programáticos, entre os realizadores da ação. Nesse sentido, muitas vezes uma ação educomunicativa é iniciada por um grupo de agentes culturais na expectativa de que outras pessoas se envolvam no processo, de forma coerente, respeitando-se sempre o ritmo e as condições que se estabelecem.

Ao falar de Educomunicação, o agente cultural se refere ao planejamento, implementação e avaliação de processos, projetos e produtos que busquem, ao máximo, aproximar-se das metas propostas pelo campo, como, por exemplo, o livre fluxo de informações entre diversas instâncias em dado ambiente; a criação de oportunidades para a expressão de diferentes atores; o uso do diálogo e da gestão participativa e democrática nos processos de tomada de decisão, etc.

Soares esclarece que foram diagnosticadas, nos últimos trinta anos, novas práticas comunicativas que estavam sendo desenvolvidas por pensadores, como Paulo Freire, e agentes sociais, como Hebert de Souza, o Betinho, que davam à comunicação

intencionalidade educativa a partir de um compromisso social definido: garantir a cada cidadão o acesso e uso democrático dos recursos da comunicação, tendo como meta a ampliação da capacidade expressiva das pessoas independentemente da condição social, grau de instrução ou inserção no mercado ${ }^{61}$.

\footnotetext{
${ }^{61}$ - Ismar de Oliveira SOARES. From Media Education to Educommunication. Symposium on Media Education, Roma, 2003, p.24
} 
Soares costuma explicar em suas palestras que historicamente as primeiras práticas que poderiam ser denominadas “educomunicativas” ocorreram nos movimentos sociais, em meados do século XX, a partir do momento em que agentes culturais se propuseram a usar instrumentos de comunicação para difundir e discutir temas ausentes, ou mesmo proibidos, nas pautas dos grandes meios e freqüentemente ocultados nos programas educativos. Entre tais temas, poderíamos destacar, por exemplo, as questões relacionadas à democracia, ao meio-ambiente, ao combate à pobreza e à diminuição da desigualdade social. Somente nos anos 80, segundo Soares, tais conteúdos, identificados como “temas transversais” nos parâmetros curriculares nacionais, passaram a ser introduzidos na sala de aula e a serem abordados com mais freqüência por alguns meios massivos.

Na rota da Educomunicação também podem ser lembradas as ações voltadas para a promoção de uma “leitura crítica dos meios”, iniciadas no Brasil a partir dos anos 70 do século passado, principalmente em projetos e movimentos relacionados à igreja cristã, como o TAT - Treinamento e Análise de Televisão (no Instituto Metodista de Ensino Superior de São Bernardo do Campo/SP) e o LCC - Projeto de Leitura Crítica de Comunicação, da UCBC - União Cristã Brasileira de Comunicação. Estas ações eram influenciadas, inicialmente, pelas correntes funcionalistas (teoria dos efeitos dos meios) e frankfurtianas (teoria de dominação ideológica dos meios sobres as massas) e refletiam na América Latina os projetos internacionalmente conhecidos como “Media Education” (Europa) ou Media Literacy (Estados Unidos) ${ }^{62}$.

Soares atualizou e ressemantizou o termo “educomunicação” (utilizado pela primeira vez pelo uruguaio Mario Kaplún para se referir expressamente à leitura crítica dos meios),

\footnotetext{
62 - Testemunham o florescimento desta prática os livros de Soares, Para uma leitura Crítica dos Jornais (São Paulo, Paulinas, 1982) e Para uma Leitura Crítica da Publicidade (Idem, 1984) e outro de João Luiz von Tilbuig, Para uma Leitura Crítica da Televisão, 1985.
} 
identificando o fato de que o conceito abrange ações de diferentes naturezas, indo além do trabalho com a recepção crítica das mensagens dos meios de comunicação. Neste sentido, a denominada “educação para os meios” passou a ser uma das áreas do novo campo e não a única. É importante ressaltar também que alguns conceitos passaram a ser referenciais como o de ecossistema comunicativo (também usado por Martín-Barbero) e o de coeficiente comunicativo das ações educativas. Antes de compreender melhor estes conceitos é importante conhecer as cinco grandes áreas da Educomunicação propostas por Soares:

- $\quad$ Educação para a comunicação,

- $\quad$ Mediação tecnológica na educação

- $\quad$ Expressão comunicativa por meio das artes

- $\quad$ Gestão da comunicação em espaços educativos

- $\quad$ Reflexão epistemológica

Estas áreas são complementares entre si e não excludentes. Trata-se de uma síntese teórica que visa a aglutinar várias ações e muitos projetos possíveis de serem implementados. As áreas da Educomunicação podem ser sintetizadas da seguinte forma ${ }^{63}$ :

\footnotetext{
63 - Ismar de Oliveira SOARES. “Caminhos da Educomunicação na América Latina e nos Estados Unidos”. In Caminhos da Educomunicação, 2.ed, Editora Salesiana, São Paulo, 2003

"Comunicação/Educação: a emergência de um novo campo e o perfil de seus profissionais”. In Contato - Revista Brasileira de Comunicação, Arte e Educação num 2, Brasília: Senado Federal, jan/mar 1999, p.19-74

"Educomunicação: as perspectivas do reconhecimento de um novo campo de intervenção social: o caso dos Estados Unidos”. In Eccos Revista Científica Uninove (v.2 n.2), dez 2000b "Metodologias da educação para comunicação e gestão comunicativa no Brasil e na América Latina”. In Maria Aparecida BACCEGA, Gestão de processos comunicacionais, São Paulo-SP, Atlas, 2002
} 
a) Educação para a comunicação: estudo das relações entre emissores e receptores das mensagens, bem como do impacto social dos meios de comunicação de massa, buscando a compreensão do papel que ocupam na sociedade. Também chamada, no exterior, de “Media Literacy” ou “Media Education”, é a mais antiga das áreas que aproximaram Comunicação/Educação, inicialmente com preocupações moralistas ou ideológicas e, atualmente, com uma visão mais dialética e construtivista.

A área compreende os meios de massa como importantes mediadores das relações sociais, para o que faz uso da contribuição dos estudos de Martín-Barbero (teoria das mediações) e dos “estudos de recepção” de autores como Guillermo Orozco, Maria Immacolata Vassallo de Lopes e Mauro Wilton de Sousa, preocupando-se com a formação de receptores autônomos e críticos frente aos meios e analisando as mudanças nos modos de percepção, negociação de sentidos e de ressignificação.

b) Mediação Tecnológica na Educação - Educação pela Comunicação: compreende os procedimentos e reflexões em torno dos múltiplos usos das tecnologias da informação nos processos educativos de maneira presencial ou virtual. Visa a capacitar professores e alunos para utilizar adequadamente os novos recursos tecnológicos de comunicação nos processos de ensino-aprendizagem e nas atividades que ampliem as possibilidades de expressão.

c) Expressão comunicativa por meio das artes: é constituída pelas ações relacionadas à expressão artística nos espaços educativos por meio de diferentes linguagens como processos de comunicação e mediação cultural. Os projetos nesta área visam 
a desenvolver atividades e projetos para estimular a expressão comunicativa da comunidade com o uso dos vários sentidos.

d) Gestão da Comunicação em espaços educativos: área voltada para diagnosticar, planejar, implementar e avaliar ações e projetos de comunicação educativa a fim de criar e manter ecossistemas comunicativos abertos e democráticos, mediados pelos processos de comunicação e por suas tecnologias. Engloba tanto questões de comunicação interna dentro das próprias instituições educativas como também as relações destas com os setores sociais, políticos e culturais nos quais estão inseridas.

e) Reflexão epistemológica: inclui as pesquisas e reflexões sobre a inter-relação Comunicação/Educação e a constituição do novo campo da Educomunicação. Busca garantir subsídios e unicidade às práticas educomunicativas e contribuir para a evolução, reconhecimento e legitimação do campo.

Quanto aos conceitos difundidos pela teoria educomunicativa podemos entender ecossistema comunicativo como o conjunto de ações que viabilizem a promoção e ampliação das relações de comunicação entre as diversas pessoas e instâncias que compõem a comunidade educativa. Inclui desde a organização do ambiente até a disponibilização dos recursos. Estimula a descentralização do poder, o diálogo, a interação e a abertura de espaço para diferentes experiências e vivências culturais. Avalia a qualidade das relações interpessoais buscando harmonia e equilíbrio em ambientes em que diversos atores possam conviver com diferentes tecnologias e meios de expressão. Soares esclarece 
que não existe apenas um modelo de ecossistema comunicativo, mas diversos, segundo os graus de interatividade presentes nos processos de trocas simbólicas ${ }^{64}$. O pesquisador ressalta a importância de uma visão dialética da presença das novas tecnologias, pois estamos passando de modelos de comunicação linear para modelos em redes, de comunicação distribuída, o que vem a desestabilizar as formas tradicionais de se fazer e se pensar educação.

Já o conceito de "coeficiente comunicativo" diz respeito à intensidade quantitativa e qualitativa das diferentes formas de expressão e comunicação tanto entre indivíduos como entre um centro emissor e uma grande audiência. Trata-se de responder à seguinte pergunta: De que forma e quanto os indivíduos e os grupos estão se comunicando? Leva em conta não apenas a quantidade de emissão de mensagens, mas também a complexidade tanto da própria mensagem como do processo criado na relação emissor-receptor. Trata-se de transformar relações burocráticas, pragmáticas e frias em “trocas” ricas, profundas, educativas e envolventes.

Além de estimular a formação de ecossistemas comunicativos abertos e democráticos, a teoria da Educomunicação evidencia várias metas a serem atingidas por meio de suas práticas de modo a trazer muitos benefícios para todos os agentes envolvidos na instituição escolar. Reunindo definições teóricas do campo da Educomunicação com a observação "in loco” de processos de capacitação de alunos, professores e funcionários, podemos levantar as seguintes vantagens que a compreensão e adoção das práticas educomunicativas podem propiciar:

a) para a escola:

- A melhoria das relações entre docentes e alunos;

\footnotetext{
64 - Ismar de Oliveira SOARES. “Caminhos da Educomunicação na América Latina e nos Estados Unidos”. In Caminhos da Educomunicação, 2.ed, Editora Salesiana, São Paulo, 2003, p.39
} 
- A atualização com novas tecnologias e formas de expressão, aproximando-se do universo cultural dos estudantes;

- A ampliação das possibilidades de registro e documentação de seus projetos sociais, esportivos e culturais, possibilitando a constituição, a manutenção e o acesso a seus acervos em novas linguagens e suportes;

- A possibilidade de professores e alunos desenvolverem suas habilidades no manejo dos recursos da produção sonora, visual e audiovisual fazendo uso democrático e participativo das novas tecnologias;

- O surgimento ou fortalecimento de grêmios estudantis e também de projetos criados e implementados conjuntamente por estudantes e professores.

b) para o educando:

- Maior envolvimento com processos e projetos inter, multi e transdisciplinares que dizem respeito ao fortalecimento do conceito e da prática da cidadania;

- A Realização de pesquisas mais elaboradas visando a enriquecer o produto comunicativo que está produzindo;

- A descoberta e o treinamento de novos talentos para trabalhar com a mídia;

- O aumento da auto-estima, a perda paulatina da timidez, resultando em maior desinibição;

- O aprimoramento da auto-confiança e da capacidade de argumentação;

- A ampliação do vocabulário e do repertório cultural;

- O aperfeiçoamento da comunicação oral, da capacidade de escuta, da atenção e da disciplina;

- A melhoria da capacidade de expressão tanto individualmente como coletivamente; 
- O desenvolvimento das atividades de forma mais lúdica, com predomínio do riso e da alegria ao reconhecer, por exemplo, sua voz em um programa de rádio ou, então, ao constatar que muitos amigos e professores assistem a um vídeo que ajudou a produzir;

- O desenvolvimento de competências de trabalho em equipe, de gestão participativa e de resolução de conflitos.

c) para o educador:

- A possibilidade de pensar o plano pedagógico da escola introduzindo de forma consciente e consistente as tecnologias de comunicação nas suas mais diferentes modalidades (foto, desenho, rádio, vídeo, TV, internet etc) resguardando suas especificidades e utilizando novas linguagens como um meio efetivo de (re)leitura do mundo e de expressão;

- A garantia mais atenção, interesse e envolvimento dos estudantes com as atividades;

- Maior facilidade para conseguir que o educando relacione os conteúdos temáticos com seu cotidiano e construa parte de seu aprendizado.

Projetos educomunicativos realizados em instituições educativas buscam garantir o envolvimento de toda a comunidade escolar porque a Educomunicação considera que a família, o entorno da escola, a educação formal e a não-formal, assim com os meios de comunicação são, atualmente, os principais mediadores sociais na formação dos cidadãos, na construção de valores, na adoção de estilos de vida, na constituição das subjetividades. Neste contexto, a pesquisadora brasileira Angela Schaun, que participou de estudos a 
respeito da constituição do novo campo, explica como a teoria educomunicativa entende as relações interpessoais:

A alteridade é o substrato constitutivo da Educomunicação, que visa relações sociais mais humanizadas, acredita na transformação do indivíduo e da sociedade, na descoberta de novos caminhos para a resolução colaborativa de problemas e, sobretudo, na criação inovadora de olhares diferentes sobre o cotidiano ${ }^{65}$.

Portanto, as práticas educomunicativas visam a incentivar o diálogo por meio do desenvolvimento das capacidades e habilidades que a comunidade escolar já possui (e pode aprimorar ainda mais) e pela apropriação das novas linguagens. Ou seja, trata-se de possibilitar que todos os cidadãos das diferentes instâncias de instituições educativas e culturais possam usar a mídia e os recursos das tecnologias de comunicação e informação a partir de seus próprios pontos de vista, necessidades, vontades e desejos. Segundo a professora da ECA-USP, Marília Franco,

É definitivamente o prazer de ver/ouvir a grande mágica sedutora das linguagens audiovisuais. Por isso mesmo tão persuasiva e pedagógica... A escola precisa encontrar na parceria com o audiovisual, a forma de resgatar a alegria do contato humano entre professores e alunos ${ }^{66}$.

A adoção de práticas educomunicativas pela comunidade escolar implica na recuperação da sensibilidade como alternativa de comunicação e aprendizagem, aproximando a escola do sistema dos meios de comunicação de forma crítica, criativa e

${ }^{65}$ - Angela SCHAUN. Educomunicação. Reflexões e princípios. Mauad Editora, Rio de Janeiro, 2002, p.8283

${ }^{66}$ - Marília FRANCO. “Linguagens audiovisuais e cidadania”. In Revista Comunicação \& Educação (9), São Paulo, maio/ago 1997, p.34 
propositiva. A Educomunicação cria oportunidades para crianças e jovens exercitarem a autonomia, a responsabilidade, a criticidade, a criatividade, a flexibilidade do pensamento, a capacidade de organizar informação e de expressar-se por meio de diferentes linguagens e suportes; estimulando o espírito de cooperação e de trabalho em grupo.

\section{2 - Pensamentos fundantes da Educomunicação}

Numa abordagem teórica multirreferencial e transdisciplinar rumo ao entendimento do conceito da Educomunicação e sua aceitação como um novo campo, podemos identificar pensadores cujas idéias têm muita relação com a proposta teórica educomunicativa e outros que podem até mesmo serem considerados precursores da Educomunicação.

Sem dúvida, o brasileiro Paulo Freire não poderia faltar nesta relação. Contra a influência iluminista na pedagogia, que acentua a “aquisição” de conteúdos curriculares, Freire realçou a dimensão cultural nos processos de formação social e ainda reforçou a necessidade de uso das novas tecnologias de forma crítica.

O construtivismo freiriano vai além da tematização e da pesquisa propondo a experiência de problematização para levar a ações transformadoras. Para Freire, o conhecimento é construído de forma interativa e integradora e não algo a ser apenas apropriado ou socializado como define a corrente da "pedagogia dos conteúdos” que de maneira instrucionista insiste na memorização. Para Freire, conhecimento implica em descoberta e construção e não apenas em cópia e retenção de informações. 
O pesquisado brasileiro Moacir Gadotti ${ }^{67}$ aponta quatro vertentes principais da teoria e da práxis de Paulo Freire:

1) Ênfase nas condições gnosiológicas ${ }^{68}$ da prática educativa. Toda obra de Freire está permeada pela idéia de que educar é conhecer, é ler o mundo, para poder transformá-lo.

2) Defesa da educação como ato dialógico e, ao mesmo tempo, rigoroso, intuitivo, imaginativo e afetivo. Paulo destaca a necessidade de uma razão dialógica comunicativa... reconhece que o ato de conhecer e de pensar estão diretamente ligados à relação com o outro. O conhecimento precisa de expressão e comunicação. Não é um ato solitário. Além de ser um ato histórico, gnosiológico e lógico, contém um quarto elemento que é sua dimensão dialógica.

3) Noção de ciência aberta às necessidades populares... seu método, por isso, não parte de categorias abstratas, mas das necessidades das pessoas, capturadas nas suas próprias expressões (valor da oralidade) e analisadas por ambos, educador e educando.

4) Planejamento comunitário participativo, a gestão democrática, a pesquisa participante.

Portanto, a teoria educomunicativa pode se valer e se orientar a partir das principais idéias de Freire, principalmente as relacionadas ao diálogo, à expressão, à problematização, ao planejamento colaborativo, às necessidades cotidianas, à afetividade e à relação horizontal educador/educando.

Outro importante pensador que devemos levar em consideração é Jürgen Habermas, pela autoria da teoria do agir comunicativo. O filósofo alemão, embora tenha se

67 - Moacir GADOTTI. “O plantador do futuro”. In: Revista Viver Mente \& Cérebro num. 4 - Coleção Memória da Pedagogia, Ed. Segmento Duetto Editorial, São Paulo, 2005, p.10-11

68 - Gnosilogia é aqui entendida como o estudo sobre o conhecimento, dos limites e condições de sua existência enquanto relação entre um sujeito e um objeto. 
aproximado da Escola de Frankfurt, afastou-se da visão negativista de Adorno. Defendia que a comunicação livre entre os pares poderia ser um meio de estabelecer consensos provisórios em que a razão comunicativa visa a superar a razão instrumental que leva ao controle e ao domínio. Como nos explica o pesquisador brasileiro José Renato Polli ${ }^{69}$, Habermas pensa não mais no sujeito solitário, mas inserido numa comunidade em que o conhecimento é lingüisticamente mediatizado e relacionado com o agir, considerando o nexo das práticas e da própria comunicação cotidianas. Nessa comunidade estão presentes as operações cognitivas com caráter intersubjetivo e cooperativo. As dimensões do agir e do fala, segundo essa compreensão, não estariam mais pré-ordenadas pela cognição, pois a prática e a comunicação assumem um papel diferente, qual seja, o da elaboração conceitual estratégica.

Os impactos causados por Habermas nas ciências humanas em geral e por Freire na educação (dois pensadores considerados “neomodernos” por muitos estudiosos) podem ser mensurados pela repercussão de suas obras e idéias. Ambos convergem para o ideal de construção do conhecimento baseado na comunicação promovendo a ligação entre aspectos morais, culturais, pedagógicos e políticos propondo novos horizontes de racionalidade a partir da dialogicidade.

Um dos pioneiros nas práticas voltadas para a comunicação alternativa em leitura crítica de comunicação e o primeiro a adotar a expressão “Comunicação Educativa”, o educador uruguaio Mario Kaplún foi, sem dúvida, um dos mais destacados teóricos latino-

\footnotetext{
69 - José Renato POLLI. Freire e Habermas. In: Revista Viver Mente \& Cérebro num. 4 - Coleção Memória da Pedagogia, Ed. Segmento Duetto Editorial, São Paulo, 2005, p.62
} 
americanos a enriquecer as discussões em torno da inter-relação Comunicação/Educação ${ }^{70}$. Em seus estudos, ressaltou a importância de se pensar a comunicação não como instrumento, mas como componente do processo pedagógico e preocupava-se com o desenvolvimento da competência comunicativa do educando.

A teoria educomunicativa também dialoga com muitas das vertentes propostas pelo sociólogo francês Edgar Morin por suas contribuições referentes ao conceito de pensamento complexo e complexidade, pela defesa de abordagens transdisciplinares nas Ciências Sociais e pela proposição de novos saberes que ele define como "necessários para a educação do século XXI”, incluindo propostas como educar para as incertezas, ensinar de forma multidimensional, compreender a complexidade da natureza humana (razão + afetividade ${ }^{71}$, desenvolver as autonomias individuais e as participações comunitárias.

Entre os teóricos da Comunicação, novos pensadores têm propiciado uma ruptura com os antigos pensamentos funcionalistas e frankfurtianos usando a perspectiva da dimensão cultural para identificar o lugar e o papel social dos meios de comunicação de massa, entre os quais destaca-se Martín-Barbero com a teoria das mediações e o entendimento da comunicação como espaço de negociação de sentidos passando a analisar os processos comunicativos não a partir do emissor mas também do receptor, ou seja, não só a partir da questão ideológica, mas também das práticas culturais dos cidadãos. Argumenta que a comunicação deve ser analisada mais pelas mediações que a envolvem do que pelos meios utilizados.

\footnotetext{
70 - Ver José MARQUES DE MELO et alli. Educomídia, alavanca da cidadania: o legado de Mario Kaplún. São Bernardo do Campo, Umesp, 2006

71 - No livro “Os sete saberes necessários à Educação do Futuro”, Edgar Morin afirma, na página 15, que o ser humano é ao mesmo tempo físico, biológico, psíquico, histórico, social e cultural e que a complexidade da natureza humana é desintegrada e separada na educação por disciplinas. Mais adiante, na página 58, o sociólogo propõe que “o século XXI deverá abandonar a visão unilateral que define o ser humano pela racionalidade (Homo sapiens), pela técnica (Homo faber), pelas atividades utilitárias (Homo economicus), pelas necessidades obrigatórias (Homo prosaicus)... O homem da racionalidade é também o da afetividade, do mito e do delírio".
} 
Martín-Barbero fala de mediação do ponto de vista da cultura, enquanto outros teóricos como Guillermo Orozco institucionalizam as mediações ao estudar a TV, a família, a escola, etc. Martín-Barbero não chega a definir com precisão o conceito de mediação, mas trouxe importantes contribuições a respeito da aproximação dos jovens com as tecnologias. Embora o conceito de mediação ainda não tenha uma definição rigorosa entre os teóricos da corrente dos "estudos culturais" vem sendo traduzido segundo Mauro Wilton de Sousa como

o esforço de identificar e captar as múltiplas ações, situações, tecnologias e circunstâncias que se colocam como categorias estruturantes do modo de ser e de viver das pessoas num tempo e espaço dados, ou seja, os sentidos sociais estruturantes da vida num contexto dado ${ }^{72}$.

Simplificadamente, podemos entender mediação como tudo aquilo que interfere na forma como percebemos e entendemos o mundo. Sousa reforça que o deslocamento da comunicação de seus meios para as mediações a coloca como parceira de processos sociais que se constroem pela interatividade alteridade.

A teoria das mediações conseguiu ampliar o campo de estudos $e$ reflexões da comunicação da problemática dos meios, dos seus conteúdos, da estrutura de suas mensagens e de seus efeitos para uma problemática muito mais abrangente na qual a cultura e a política constituem mediações constitutivas fundamentais. É uma epistemologia que articula o mundo dos meios com uma história cultural... O mérito de Jesús Martín-Barbero foi ter deslocado a perspectiva de pensamento em comunicação, mudando perguntas e problemas. Ter levantado uma crítica permanente e sistemática

72 - Mauro Wilton de SOUSA. “O lugar social da comunicação mediática”. In Caminhos da Educomunicação, 2.ed, Editora Salesiana, São Paulo, 2003, p.32 
às formas funcionalistas, semioticistas e denuncistas permitindo uma revolução importante de nosso campo de estudos a partir da década de 80 porque soube juntar erudição teórica com processos históricos socioculturais essenciais ${ }^{73}$

As mudanças de perguntas propostas por Martín-Barbero dizem respeito a deixar de responder apenas “o que os meios fazem com as pessoas?” e passar a questionar "o que as pessoas fazem com os meios?”.

Mauro Wilton de Sousa afirma que as limitações das primeiras teorias do campo da Comunicação levaram a novos caminhos como buscar compreender os movimentos internos vivenciados pela sociedade no final do século XX e tentar identificar as relações criadas com os media, identificar a comunicação mais como processo social do que apenas instrumentalidade tecnológica ${ }^{74}$.

Para tentar compreender o conceito de mediação a partir de um estudioso do campo da educação podemos voltar no tempo e referenciar o bielo-russo Lev Vygotsky por suas concepções sobre o desenvolvimento humano como processo sócio-histórico. Entendia que o homem, enquanto sujeito do conhecimento, não tem acesso direto aos objetos, mas acesso mediado, por recortes do real, operados pelos sistemas simbólicos de que dispõe. Enfatizava a construção do conhecimento como uma interação mediada por várias relações. Desta forma, o conhecimento, assim como no construtivismo, era estabelecido pela mediação feita com outros sujeitos.

\footnotetext{
73 - Alberto Efendy Maldonado Gómez de la TORRE. Pesquisa teórica em comunicação na América Latina (estudo de três casos relevantes: Verón, Mattelart e Martín). Tese de doutorado, ECA/USP, 1999, cap.III, p.6-7

74 - idem, p.27
} 
Comparando-se as teorias de Vygotsky e Jean Piaget podemos afirmar que o primeiro se diferencia do segundo principalmente por ter dado mais importância à situação social e ao meio do sujeito educando. Por isso, Vygotsky, ao destacar o papel do contexto histórico e cultural nos processos de desenvolvimento e aprendizagem, é chamado de “sociointeracionista”, e não apenas de "interacionista” como Piaget.

O construtivismo, como proposta pedagógica, e a teoria das mediações, como objeto da ciência da comunicação, são formulações teóricas que centram seu interesse no receptor. Enquanto qualquer mensagem midiática que chega aos alunos é filtrada, negociada, mediada pela bagagem cultural dos estudantes, o mesmo ocorre em processos educativos tendo em vista que o aprendizado se dá a partir do referencial cognitivo do aprendiz. Percebemos aí a riqueza da inter-relação Comunicação (mediações) e Educação (construtivismo) para defender a necessidade de um sistema de ensino voltado para o ambiente sociocultural da comunidade escolar, com conteúdos relacionados às suas necessidades, vontades e à resolução de problemas e conflitos do seu cotidiano.

\section{3 - A área da "mediação tecnológica na educação”}

No âmbito desta pesquisa aprofundaremos as questões e discussões relacionadas à área da "mediação tecnológica na educação" (sempre que possível relacionando-a às demais áreas da Educomunicação) por se tratar da problemática que nos propusemos a investigar e pela sua relação direta com nosso objeto de pesquisa, as produções radiofônicas do projeto 
“educom.rádio”. Esta área adverte que o desenvolvimento tecnológico dos setores relacionados à informação e à comunicação e suas aplicações na sociedade não permitem mais que a escola continue a ignorá-los. A “mediação tecnológica na educação” favorece:

- a introdução dos recursos midiáticos e das novas linguagens para facilitar a criação de ambientes comunicativos e estimular a discussão de temas transversais relacionados ao cotidiano da sociedade como sexualidade, diversidade, meioambiente, cidadania, direitos, política, violência, etc.

- a criação de estratégias e decisões sobre o uso das tecnologias de comunicação baseadas na realidade de quem vai utilizá-las, questionando a relação "adultoprodutor”, “criança/jovem-receptor” e defendendo que todos os atores sociais têm direito à expressão.

As atividades educomunicativas relacionadas a esta área provocam reações diferentes em docentes e alunos: enquanto os primeiros se mostram muitas vezes receosos e resistentes, os estudantes demonstram vontade e interesse em ter acesso às tecnologias de comunicação e passar a utilizá-las na relação ensino-aprendizagem. Estamos lidando com processos que podem provocar mudanças na relação professor-aluno, na medida em que os docentes passam a assumir muitas vezes o papel de aprendizes nas atividades mediadas pelas tecnologias.

Os meios tecnológicos clássicos como o rádio e televisão enfrentam dificuldades para serem utilizados em instituições educativas porque muitos educadores identificam neles apenas seu caráter lúdico e mercantil. Recentes ou antigas, as tecnologias precisam, antes de mais nada, serem desmistificadas pelo sistema educativo superando tanto as atitudes de "ufanismo tecnológico" (por parte daqueles que só vêem qualidades e benefícios no uso da 
tecnologia) quanto as atitudes de “tecnofobia” (que demoniza as tecnologias de informação como algo pernicioso que deve continuar longe da escola).

É fundamental discutir até que ponto a tecnologia pode propor novos olhares e caminhos ou, se ao contrário, pode limitar-se a dar nova roupagem ao velho, ao tradicional, ao conservador. Nesta perspectiva vale ressaltar a diferença entre técnica e tecnologia. O conceito de técnica que nos é apresentador pelo dicionário Aurélio a define como a parte material ou o conjunto de processos de uma arte, maneira, jeito ou habilidade especial para executar ou fazer algo. A técnica pode ser entendida como a aplicação prática do saber. Já a tecnologia é a sinergia entre técnica e ciência, a utilização e criação de teorias e métodos científicos para o desenvolvimento de técnicas reconhecendo-se aí uma função cognitiva.

Quando a técnica é pensada, explicada, esquematizada e atinge o universo teórico, racional, científico transforma-se em tecnologia. Segundo a pesquisadora brasileira Mirza Seabra Toschi, tecnologia é algo que se estuda e se aprende uma vez que é parte da cultura. Tecnologia não são apenas aparelhos, equipamentos, não são puro saber-fazer; são cultura que tem implicações éticas, políticas, econômicas e educacionais. ${ }^{75}$

Entender e discutir a lógica das tecnologias de informação e comunicação passa, nesse contexto, a ser pré-requisito de uma educação de qualidade, porém tomando o cuidado de não correr o risco de cair numa mera simplificação. Não são as tecnologias que irão mudar, melhorar ou revolucionar o ensino, mas as maneiras como serão utilizadas. A construção de ricos processos de interação e comunicação nos espaços educativos depende muito mais dos agentes sociais envolvidos e das técnicas empregadas e discutidas do que das

\footnotetext{
75 - Mirza TOSCHI. "Linguagens midiáticas e formação de professores”. IN: Dalva ROSA \& Vanilton SOUZA (org). Didática e práticas de ensino: interfaces como diferentes saberes e lugares formativos. Rio de Janeiro, DP\&A Editora, 2002
} 
tecnologias utilizadas (sejam estas desde o giz e a lousa, passando pelo livro, até chegar ao computador).

Não se trata de reduzir as tecnologias a suportes (incluindo aí os midiáticos), mas de saber aproveitar todo o seu potencial e criar lógicas, linguagens e maneiras particulares de se comunicar com as capacidades emocionais, perceptivas, intuitivas, cognitivas e expressivas da comunidade escolar estabelecendo processos democráticos e interativos. Neste sentido, podemos aproveitar um conceito-chave de Pierre Levy ${ }^{76}$ que em seu livro “Tecnologias da Inteligência” adverte que a construção da inteligência coletiva não é a soma das inteligências individuais, mas a interação entre elas.

Landislau Dowbor ${ }^{77}$ explica que existe uma ordem hierárquica conceitual entre “dados”, “informação”, “conhecimento” e "sabedoria”. Segundo o professor francês dados são elementos fragmentados que organizados constituem uma informação. Quando esta é elaborada pelo sujeito que a utiliza transforma-se em conhecimento. Sabedoria seria a harmoniosa relação entre conhecimento, valores e ação.

Em raciocínio semelhante, a pesquisadora brasileira Maria Aparecida Baccega ${ }^{78}$ diferencia informação de conhecimento explicando que enquanto as informações chegam fragmentadas e, muitas vezes, desconectadas ou descontextualizadas, o conhecimento é a capacidade de reelaborar o que vem como um dado, possibilitando que o receptor não seja um mero reprodutor e torne-se também capaz de estabelecer relações entre diferentes áreas e perceber a dinâmica entre elas.

\footnotetext{
76 - Pierre LÉVY. As tecnologias da inteligência - O futuro do pensamento na era da informática. Editora 34, Rio de Janeiro, 1993

77 - Landislau DOWBOR. Tecnologias do conhecimento: os desafios da comunicação. Petrópolis, Ed. Vozes, 2001, p.33

78 - Maria Aparecida BACCEGA. “Conhecimento, informação, tecnologia”. In Revista Comunicação \& Educação (11). São Paulo, Ed. Moderna, 1999
} 
Alguns pesquisadores podem ficar receosos frente à denominação de "mediação tecnológica” dada a esta área da Educomunicação. É importante ressaltar que os educomunicadores entendem nesta nomenclatura que o conceito de “mediação” é muito mais importante do que o de "tecnológica". O processo como se estabelece a comunicação aparece à frente dos meios e aparatos da tecnologia. Como o próprio nome da área a define, o que se propõe é o âmbito das mediações acima da mera instrumentalidade tecnológica.

Projetos implementados de acordo com os parâmetros da Educomunicação não dizem respeito ao que se costuma chamar de uso instrumental da tecnologia ou apenas à leitura crítica dos meios ou, ainda, à utilização de produtos audiovisuais (que já chegam prontos) na sala de aula para ilustração de conteúdos. Entender a "mediação tecnológica no espaço educativo” (ou “educação pela comunicação”) como uma área extremamente importante da Educomunicação corresponde a oferecer aos alunos, aos professores, aos funcionários e à comunidade ao redor da escola oportunidades de se tornarem criadores, realizadores, produtores de informação, conteúdo e conhecimento (por meio de boletins impressos, pequenos jornais, revistas, programas de rádio, fotografias, vídeos, programas de TV, sites, etc) utilizando as tecnologias de comunicação e as novas mídias.

Atividades como estas, além de permitir o desenvolvimento de outras competências expressivas do educando (verbal-oral, verbal-escrita, sonora, visual, audiovisual, interativa), ainda podem contribuir para a criticidade em relação à leitura dos meios. Após aprender, na prática, por exemplo, como funciona a edição de um vídeo (cortar depoimentos, mudar ordem das imagens, colocar uma trilha sonora, etc) o educando irá adquirir maior bagagem midiática para avaliar e questionar os produtos audiovisuais que já chegam prontos e editados. Trata-se do que Guillermo Orozco chama de "alfabetização múltipla” nos diversos meios e tecnologias de produção, circulação e apropriação de 
saberes e conhecimentos, uma alfabetização que como no caso da linguagem escrita, possibilite aos educandos interagir com outros meios e expressar-se através deles ${ }^{79}$. Para o pesquisador mexicano, precisamos assumir a escola como a instituição articuladora da diversidade de linguagens, códigos e gêneros narrativos e midiáticos ${ }^{80}$. Ao analisar o mesmo tema, o estudioso inglês David Buckingham, especialista em questões relacionadas à infância, destaca que está surgindo recentemente uma visão mais positiva da relação entre crianças e meios eletrônicos, segundo a qual

as crianças longe de serem consideradas vítimas passivas dos meios, são vistas como possuidoras de uma sólida forma de “alfabetismo midiático”, uma sabedoria natural espontânea que os adultos não possuem; em particular, se pensa que as novas tecnologias de comunicação brindam as crianças com novas oportunidades para a criatividade, a coletividade e a realização pessoal $^{81}$.

A alfabetização midiática do educando precisa ser entendida como um dos elementos da alfabetização múltipla que nos propõe Orozco. À medida que vivenciam as etapas de produção, os estudantes passam a entender melhor como se produz informação e, conseqüentemente, podem comparar a metodologia de trabalho de projetos de Educomunicação, por exemplo, com o procedimento adotado por grandes empresas de comunicação, que muitas vezes pautam suas produções pelos princípios de mercado interessadas em formar novos consumidores, aumentando audiência e faturamento.

79 - Guillermo OROZCO. “Elementos para uma política de educación mediática”. In Carlos VALDERRAMA. Comunicación-Educación, Coordinadas, abordajes y travesías. Bogotá, Universidad Central/DIUC, 2000, p.125

80 - idem

81 - David BUCKINGHAM. Crecer en la era de los medios electrónicos. Madrid. Morata, 2002, p. 54 
Trata-se, acima de tudo, de resgatar o ideal de aprendizagem como produção de sentidos (e não como reprodução), de trabalhar a sensibilidade e a subjetividade dos alunos aproveitando a empatia destes com a cultura tecnológica, de propiciar o rompimento com o modelo linear de comunicação que existe na escola permitindo a integração em redes dialéticas e interativas. Ou seja, descartar modelos e processos que entendem o educando apenas como receptor para permitir sua postura ativa, colocando o aprendiz no centro da aprendizagem.

As mídias e as tecnologias de informação e comunicação não devem ser introduzidas na escola para formar excelentes “apertadores de botões” ou navegadores ávidos das informações que parecem infinitas disponíveis no “infomar” da Internet. O desafio é aproveitar o caráter lúdico, moderno e instigante dos meios de comunicação para o desenvolvimento de novos modelos de ensino-aprendizagem, despertando a criticidade, a responsabilidade, a auto-estima e a motivação dos educandos. Soares, destacando as idéias de Marisol Moreno, afirma que a aprendizagem se dá quando o indivíduo sente-se tocado, envolvido, conectado. Nesse sentido o ambiente mediado por tecnologias pode ajudar a produzir sentidos, convertendo-se em mediação. É o sentido que provoca a aprendizagem, não a tecnologia ${ }^{82}$.

O suíço Jean Piaget ${ }^{83}$ já afirmava que não há construção de conhecimento sem motivação afetiva ${ }^{84}$, advertindo que apesar de diferentes em sua natureza, a afetividade e a cognição são inseparáveis. Postulou que toda ação e pensamento comportam um aspecto

\footnotetext{
82 - Ismar de Oliveira SOARES. "Metodologias da educação para comunicação e gestão comunicativa no Brasil e na América Latina”. In Maria Aparecida BACCEGA, Gestão de processos comunicacionais. São Paulo, Atlas, 2002, p.123

83 - Jean PIAGET. Inteligencia y afectividad. Buenos Aires: Aique, 2001.

${ }^{84}$ - A primeira vez que Jean Piaget relacionou cognição e afetividade foi em um trabalho publicado a partir de um curso ministrado na Universidade de Sorbonne (Paris) entre 1953 e 1954 chamado "Les relations entre l'intelligence et l'affectivité dans le développement de l'enfant".
} 
cognitivo, representado pelas estruturas mentais, e um aspecto afetivo, representado por uma energética, a afetividade.

Neste sentido, o sociólogo francês Edgar Morin também contribui para o entendimento da importância da afetividade nos processos de mediação tecnológica na educação ao afirmar que:

A afetividade pode asfixiar o conhecimento, mas pode também fortalecê-lo. Há estreita relação entre inteligência e afetividade: a faculdade de raciocinar pode ser diminuída, ou até mesmo destruída, pelo déficit de emoção; o enfraquecimento da capacidade de reagir emocionalmente pode estar até mesmo na raiz de comportamentos irracionais. Portanto não há um estágio superior da razão dominante da emoção, mas um eixo intelecto-afeto e, de certa maneira, a capacidade de emoções é indispensável ao estabelecimento de comportamentos racionais. ${ }^{85}$

Enquanto para o construtivismo, o conhecimento se dá a partir da ação do sujeito sobre a realidade, para Vygotsky ${ }^{86}$ esse sujeito não é apenas ativo, mas também interativo porque se constitui a partir de relações intra e interpessoais. Vygotsky acrescenta a visão social, a relação da criança e do jovem com outras instituições além da escola e com outros indivíduos com bagagem histórica e cultural. Se para Piaget a aprendizagem depende do estágio de desenvolvimento atingido pelo sujeito, para Vygotsky a aprendizagem favorece o desenvolvimento das funções mentais. Identificamos algumas propostas teóricas de Vygotsky muito úteis para a teoria educomunicativa na medida em que esta defende e incentiva o diálogo, a gestão participativa e democrática, a voz ativa e a postura interativa

\footnotetext{
85 - Edgard MORIN. Os sete saberes necessários à Educação do Futuro. Ed. Cortez, 9.ed, São Paulo, 2000, p.20-21

86 - João Batista MARTINS. Vygotsky \& a educação. Autêntica, Belo Horizonte, 2005
} 
do educando. Para Vygotsky, o processo de constituição de conhecimentos é tão importante quanto o produto (o conhecimento adquirido e avaliado por meio das provas). Para a Educomunicação, o processo de realização é até mais valorizado do que o produto final midiático. Vygotsky define, ainda, o papel do professor com um agente “mediador” e não como um "mestre" que ensina os educandos passivos. Neste sentido, a Educomunicação ao propor que o professor aja como um "educomunicador" o identifica a um facilitador das ações que viabilizem o papel do educando como um produtor de sentidos, de conhecimentos, de informações evitando processos verticais que Paulo Freire denominou de “educação bancária”, na qual a educação é entendida como “transmissão” de conhecimento.

O jornalista Fernando Rossetti ${ }^{87}$, realizador de um estudo sobre projetos brasileiros de intervenção que atuam na tríade Educação/Comunicação/Participação, alerta para um grave problema que pode desvirtuar a intencionalidade educativa (principalmente do ponto de vista do processo) em atividades e projetos de mediação tecnológica na educação:

É possível escolarizar (no mal sentido) a criação de um produto de comunicação, formatando e planejando de antemão todas as atividades, de forma que, quando os alunos se envolvem na produção acabam lidando com poucos dos desafios que teriam que superar na vida real.

Quanto ao processo de ensino-aprendizagem, os estudos de Howard Gardner a respeito de sua teoria das inteligências múltiplas ressaltam a importância de permitir que o educando tenha efetivamente a possibilidade de se envolver com as diferentes etapas de realização de produtos midiáticos em projetos que tenham como eixo os princípios da

87 - Fernando ROSSETTI. Mídia e escola - Perspectivas para políticas públicas. Edições Jogo de Amarelinha, São Paulo, 2005, p.85 
mediação tecnológica na educação. O psicólogo norte-americano organiza uma relação de várias competências divididas em três categorias de inteligência ${ }^{88}$ : as racionais (“lingüística” e “lógico-matemática”), as corporais (“espacial”, “corporal-cinestésica” e “musical/sonora”) e as pessoais (“intrapessoal” e “interpessoal”).

A teoria de Gardner nos ajuda a conscientizar os educadores a respeito da importância da realização de produtos de comunicação audiovisual por crianças e jovens e seu grande potencial de estimular as variadas competências e categorias de inteligência. A adoção de práticas educomunicativas com realização participativa de produtos sonoros, visuais, audiovisuais, multimídia, etc permite que os estudantes não sejam mais avaliados apenas por meio de textos, provas escritas, ditados, redações, contas, cálculos (inteligências racionais), mas que se expressem também por meio de outras linguagens e tenham novas possibilidades de produção de sentidos e construção de conhecimento de forma dialógica e interativa.

É possível trabalhar as sete inteligências múltiplas em uma atividade educomunicativa de mediação tecnológica: a "lingüística” e a "lógico-matemática” (na definição da pauta, nos roteiros, no conteúdo); a "espacial”, a "corporal-cinestésica” e ou a "musical/sonora” (no uso das linguagens, na definição de formatos midiáticos, nos ensaios, nas gravações de vídeos ou de programas de rádio, etc) e transversalmente em todas as etapas do processo a “intrapessoal” e a “interpessoal” (desde a escolha da pauta por meio de gestão participativa e democrática até a avaliação final em grupo do produto e do processo).

Portanto, o desenvolvimento das inteligências múltiplas pode ser potencializado por ações e projetos que envolvam as tecnologias da inteligência. Como esclarece Pierre Lévy,

\footnotetext{
88 - Howard GARDNER. Estruturas da mente. A teoria das inteligências múltiplas. Porto Alegre, Artes Médicas Sul, 1994
} 
não se trata de usar as tecnologias a qualquer custo, mas sim de acompanhar consciente e deliberadamente uma mudança de civilização que questiona profundamente as formas institucionais, as mentalidades e a cultura dos sistemas educacionais tradicionais e sobretudo os papéis de professor e de aluno... É a transição de uma educação e uma formação estritamente institucionalizada (a escola, a universidade) para uma situação de troca generalizada de saberes, o ensino da sociedade por ela mesma, de reconhecimento auto-gerenciado, móvel e contextual das competências ${ }^{89}$.

Quando falamos das competências na área da mediação tecnológica na educação não nos referimos à capacitação e formação de ótimos “apertadores de botões”. O desenvolvimento das competências dos estudantes não está relacionado somente à operação dos equipamentos. Um aluno, por exemplo, pode ter adquirido competência para pensar um processo completo de comunicação para realização de determinado projeto e não precisar apertar nenhum botão dos equipamentos que geram os produtos deste processo. É importante ressaltar que o processo de realização dos produtos de comunicação em âmbito escolar (por meio da gestão participativa e democrática, do respeito à pluralidade e à diversidade, do senso de responsabilidade, do desenvolvimento da criticidade, e da elevação da auto-estima) é mais importante do que o resultado final e a qualidade técnica do produto. O objetivo primordial é estimular e desenvolver a competência comunicativa dos cidadãos envolvidos no processo.

Outro ponto fundamental é compreender que a busca por este objetivo não deve esbarrar em uma eventual escassez de recursos técnicos e/ou financeiros. O estímulo a um bom planejamento aliado ao interesse da comunidade escolar em implementar projetos e realizar

89 - Pierre LÉVY. Cibercultura. São Paulo: Ed. 34, 1998, p.172 
seus produtos midiáticos podem potencializar o desenvolvimento de soluções criativas para todo o processo educativo. Muitas vezes, os estudantes por meio de expressões corporais e sonoras aliadas à utilização de objetos do cotidiano conseguem obter os efeitos e resultados desejados. A realização de produtos criativos não deve estar relacionada à sofisticação de determinado equipamento, mas às soluções inovadoras propostas pelo grupo. Ao acompanhar de perto atividades práticas verificamos bons exemplos de adaptações criativas. Por exemplo, durante o período de formação das escolas no projeto “educom.rádio” foi possível presenciar muitos casos de atraso do recebimento do kit completo de equipamento do rádio (com mesa de som, microfones, toca CDs, duplo deck, etc.). Neste período, estudantes, professores e membros da comunidade conseguiram realizar inúmeras produções radiofônicas utilizando apenas um gravador de mão e buscando soluções alternativas e criativas para suprir a falta de materiais e equipamentos mais sofisticados.

Além do desenvolvimento simultâneo de muitas competências (ou inteligências múltiplas como define Gardner) as ações práticas de mediação tecnológica também propiciam a transdisciplinaridade. Geralmente, quando se faz um produto midiático na escola, como um programa de rádio, não se trabalha, por exemplo, primeiro a Língua Portuguesa, depois Biologia, logo após Educação Artística, etc... Quase sempre os conteúdos são trabalhados simultaneamente e por um período de tempo mais longo do que a duração tradicional das aulas de 45 ou 50 minutos.

Portanto, o segredo do sucesso de projetos de mediação tecnológica na educação reside em aliar criatividade com desenvolvimento da capacidade expressiva, buscando primeiramente ótimos processos em vez de bons produtos. 


\section{4 - Educomunicador: o perfil de um novo profissional}

A teoria da Educomunicação entende que muitos profissionais vindos principalmente das áreas da Comunicação e da Educação (mas também de outros campos do saber) vêm desempenhando, na prática, muitas funções sociais e educativas que poderiam ser atribuídas às áreas de atuação de um “educomunicador”. Trata-se da tentativa de traçar o perfil de um profissional que agrega conhecimentos e práticas da Comunicação e da Educação sendo capaz de superar a visão iluminista e funcionalista das relações sociais. Um educomunicador, segundo a literatura produzida pelo NCE-USP, é capaz de atuar implementando ações de:

- Gestão da comunicação e da informação em centros culturais, instituições, emissoras educativas e principalmente em escolas;

- Mediação tecnológica nos processos educativos, estimulando, assessorando e articulando ações e projetos de expressão comunicativa;

- Promoção da expressão artística mediada pela produção midiática e do fortalecimento do protagonismo infanto-juvenil;

- Estudos sobre recepção midiática e desenvolvimento de ações para a análise e discussão do papel da mídia bem como dos produtos e linguagens dos meios de massa;

- Pesquisas, reflexões epistemológicas sobre a inter-relação Comunicação/Educação.

Nesse sentido, o educomunicador atua nessas áreas visando a: 
- Facilitar a produção, a difusão e a circulação de informações;

- Promover a interatividade e o diálogo nos processos de ensino-aprendizagem;

- Conhecer e fornecer referenciais teóricos e metodológicos para análise da produção midiática buscando uma adequada formação para a compreensão do sistema dos meios de comunicação de massa;

- Buscar convergências de ações para ampliar o potencial comunicativo das ações desenvolvidas.

Para isso, o educomunicador se orienta por teorias, conceitos e ideais relacionados à:

- Comunicação dialógica;

- Ética e à responsabilidade social;

- Alfabetização múltipla;

- Teoria das mediações;

- Educação construtivista;

- Relação horizontal professo-aluno;

- Entendimento do erro como parte do processo de aprendizagem;

- Recepção ativa e crítica pelas audiências; poder de “negociação” do receptor em relação aos produtos dos meios de massa;

- Diversidade cultural do grupo e subjetividade de cada agente envolvido.

Portanto, o educomunicador é entendido como um profissional capaz de assessorar educadores ou instituições educativas para o uso adequado dos recursos de comunicação como meios de expressão da cidadania podendo atuar em instâncias que vão desde a 
elaboração e coordenação de projetos e políticas públicas até a atuação direta em sala de aula ou com pequenos grupos em espaços formais ou não-formais de ensino. Trata-se de um facilitador das ações de outras pessoas para que elas mesmas possam criar, implantar e avaliar projetos e materiais a partir de suas necessidades e de seus interesses tornando-se produtoras de informação e conhecimento visando à transformação do ambiente em que vivem ou com o qual se relacionam.

\section{5 - Educomunicação: do diálogo nacional com a LDB à lei municipal em}

\section{São Paulo}

Analisando o recente cenário político desde a esfera municipal de uma cidade como São Paulo que ofereceu capacitação em Educomunicação (por meio do projeto “educom.rádio”) para alunos e professores de todas as suas 455 escolas de Ensino Fundamental, chegamos à conclusão de que o conceito em estudo ultrapassou o restrito espaço acadêmico para consolidar-se como objeto de política pública. É justamente na esfera pública, em níveis municipal, estadual e nacional que a Educomunicação vem se consolidando enquanto prática educativa e social ${ }^{90}$.

Na esfera nacional podemos identificar conceitos da Educomunicação dialogando com as últimas mudanças estabelecidas na LBD (Lei de Diretrizes e Bases) que orientam a

\footnotetext{
90 - O tema da Educomunicação como política púbica é o objeto da pesquisa de doutorado de Patrícia Horta, co-fundadora do NCE-USP e principal articuladora dos projetos do Núcleo nestes dez anos (1996-2006) de trabalho dedicados à pesquisa e à assessoria na implementação de projetos educomunicativos.
} 
introdução, nos currículos, de parâmetros relacionados à Educação para a Comunicação e à presença das tecnologias e dos meios de comunicação de massa. De acordo com as Diretrizes Curriculares Nacionais do Ensino Médio (DCNEM), estabelecidas em resolução de 26 de junho de 1998, para cumprir as finalidades do Ensino Médio, as escolas deverão reorganizar seus currículos de modo a ter presente que as linguagens são indispensáveis para a constituição de conhecimentos e competências e adotar metodologias de ensino diversificadas, que estimulem a reconstrução do conhecimento e mobilizem o raciocínio, a experimentação, a solução de problemas e outras competências cognitivas superiores (artigo $5^{\circ}$ ).

O artigo 10, que determina a organização do currículo sistematizada em três grandes áreas, nomeia a primeira delas de “Linguagens, Códigos e suas Tecnologias”, a qual determina, entre outros objetivos, que o educando possa:

- “Compreender e usar os sistemas simbólicos das diferentes linguagens como meios de organização cognitiva da realidade pela constituição de significados, expressão, comunicação e informação";

- “Analisar, interpretar e aplicar os recursos expressivos das linguagens, relacionando textos com seus contextos, mediante a natureza, função, organização, estrutura das manifestações, de acordo com as condições de produção e recepção”;

- "Entender os princípios das tecnologias da comunicação e da informação, associálas aos conhecimentos científicos, às linguagens que lhes dão suporte e aos problemas que se propõem solucionar”;

- “Entender a natureza das tecnologias da informação como integração de diferentes meios de comunicação, linguagens e códigos”; 
- “Entender o impacto das tecnologias da comunicação e da informação na sua vida, nos processos de produção, no desenvolvimento do conhecimento e na vida social”;

- “Aplicar as tecnologias da comunicação e da informação na escola, no trabalho e em outros contextos relevantes para sua vida”.

A adoção, na prática, dos múltiplos usos das novas tecnologias nos ambientes educativos não depende, no entanto, somente do desenvolvimento tecnológico, mas principalmente de decisões políticas e institucionais. O sistema escolar tem uma longa trajetória histórica e mantém uma série de práticas consolidadas que são difíceis de serem modificadas a curto prazo principalmente quando este percebe que as novas propostas podem interferir tanto na manutenção das hierarquias e formas de poder como nos processos de ensino-aprendizagem.

Neste sentido, o projeto “educom.rádio", baseado nos fundamentos teóricos da Educomunicação, propiciou a compreensão de várias linguagens de informação e comunicação no ambiente escolar, conforme recomendam os Parâmetros Curriculares Nacionais, bem como orientou a elaboração de um planejamento do plano políticopedagógico visando à construção de um ecossistema comunicativo fundamentado na gestão participativa e democrática dos atores envolvidos e a continuidade de práticas educomunicativas utilizando os meios de comunicação, principalmente o rádio.

No caso da cidade de São Paulo, a legislação veio depois da prática. A capacitação oferecida pelo NCE-USP nas escolas começou em 2001 e apenas no final de 2004, alguns dias após o encerramento do período de formação do projeto “educom.rádio”, a proposta educomunicativa virou lei em 28/12/2004 com o número 13.941, instituindo o "Programa 
Educom - Educomunicação pelas ondas do rádio ${ }^{91 \%}$. O inciso $1^{\circ}$, do artigo $1^{\circ}$, define Educomunicação como o conjunto dos procedimentos voltados ao planejamento $e$ implementação de processos e recursos da comunicação e da informação, nos espaços destinados à educação e à cultura ${ }^{92}$. Já o inciso $2^{\circ}$ do mesmo artigo define como objetivo principal da lei ampliar as habilidades e competências no uso das tecnologias, de forma a favorecer a expressão de todos os membros da comunidade escolar, incluindo dirigentes, coordenadores, professores, alunos, ex-alunos e demais membros da comunidade do entorno $^{93}$. A lei determinou ainda que seria instituído um comitê gestor com representantes do governo e da sociedade civil execução e viabilização das determinações.

Em 12 de junho do ano seguinte, foi eleita a primeira diretoria do Comitê Gestor da Lei Educom. O professor Carlos Alberto Mendes de Lima, representante dos professores de ensino fundamental e médio, assumiu a presidência e o professor Ismar de Oliveira Soares, representante da USP, foi eleito vice-presidente.

Embora tardias, tais iniciativas representam, sem dúvida, um avanço institucional e político para a compreensão do papel da comunicação na sociedade atual e abre novas possibilidades para ações e projetos que estimulem a capacidade expressiva dos agentes envolvidos nas diferentes instâncias escolares, especialmente dos estudantes. Enquanto os órgãos reguladores da educação tentam buscar caminhos para atualizar o sistema de ensino com a presença das tecnologias na sociedade, a Educomunicação segue consolidando sua teoria com capacidade para subsidiar cada vez mais desde propostas teóricas e metodológicas de projetos realizados em parceria com o poder público até decisões regulatórias.

\footnotetext{
91 - Publicado no DOM (Diário Oficial do Município de São Paulo) num. 243, em 29/12/2004, p. 1

92 - idem

93 - idem
} 


\section{Capítulo 3}

\section{O projeto “educom.rádio”: da concepção à avaliação}

O educom.rádio não é apenas um curso de técnicas radiofônicas: o objetivo

é repensar a relação escola/comunicação. ${ }^{94}$

(Ismar de Oliveira Soares)

\section{1 - Formulação e desenvolvimento do projeto}

Neste capítulo abordamos o funcionamento operacional e logístico do projeto “educom.rádio” analisando as principais características e mudanças pelas quais o projeto passou de sua concepção à sua implementação.

É importante ressaltar, de início, que a porta de entrada que levou à parceria do NCEUSP com a Prefeitura de São Paulo não foi, especificamente, a comunicação em si ou a Educomunicação, mas a perspectiva do poder público em contar com uma ação educativa que tivesse como objetivo a prevenção da violência nas escolas.

Em maio de 2001, o NCE-USP apresentou para apreciação do "Projeto Vida", organismo da Secretaria Municipal de Educação voltado ao combate à violência nas escolas da capital paulista, a proposta "Novas Ondas - Gestão de Comunicação, via Rádio, em Escola numa Situação de Conflito”. Tratava-se de um projeto-piloto, desenhado para uma escola pública de Ensino Fundamental (a EMEF Benedito de Jesus Batista Laurindo -

\footnotetext{
94 - Ismar de Oliveira SOARES. “Agora, é planejar a Educomunicação!” In Agenda do educom.rádio num. 2, São Paulo, 2004, p.1

${ }^{95}$ - O “Projeto Vida” foi instituído a partir da aplicação da lei 13.096, de 08/12/2000.
} 
Padre Batista) com duração de 12 meses $^{96}$. Esta proposta inicial foi recusada sob a alegação de que o “Projeto Vida” não incluiria em sua agenda de trabalho projetos experimentais ou ações que se restringissem a uma única escola.

Interessava, contudo, à professora Dirce Gomes, uma proposta voltada de forma equânime a todas as escolas da rede municipal. Nesse sentido, o NCE-USP foi convidado a formular uma linha de ação mais abrangente para o combate às diversas formas de violência nas escolas que abarcasse toda a rede de Ensino Fundamental da cidade, composta por 455 escolas.

O projeto foi reformulado em junho de 2001 por Ismar de Oliveira Soares (que redigiu as diretrizes do projeto em Educomunicação e eixos temáticos) e Patrícia Horta Alves (responsável pela articulação da operacionalização incluindo a divisão das atividades por regiões e as estimativas orçamentárias) ${ }^{97}$. Coube, assim, ao NCE-USP desenvolver um programa que conciliasse a teoria educomunicativa com as metas do "Projeto Vida”. Nesse sentido, foi pensada a prática radiofônica sob o argumento de que o estímulo à gestão participativa e à expressão dos jovens ajudaria a reduzir os índices de conflito, ao melhorar a auto-estima dos adolescentes e as relações de comunicação na escola.

O novo projeto foi batizado de “Educomunicação pelas ondas do rádio - Construindo a Paz pela Comunicação” ou, simplesmente, “educom.rádio”. Desta forma, estabeleceu-se

\footnotetext{
96 - A elaboração da proposta tomou como base a experiência prévia do NCE-USP e de algumas mestrandas do programa de Pós-graduação da ECA-USP, como Patrícia Horta Alves, Grácia Lopes Lima e Márcia Coutinho Jimenez. No processo participou a aluna do curso de Gestão de Processos Comunicacionais da ECA-USP, Fátima Yunes, professora da EMEF Benedito de Jesus Batista Laurindo - Padre Batista, que tomou a iniciativa de apresentar o NCE-USP ao Projeto Vida, coordenado pela professora Dirce Gomes. É importante notar que a professora Fátima Yunes inscreveu-se como aluna do projeto, em 2001, mantendo-se vinculada ao programa durante algumas fases subseqüentes, oferecendo assistência aos colegas professores do antigo NAE 8.

97 - Para formulação do projeto “educom.rádio”, finalmente aceito pela Prefeitura, o NCE-USP continuou contando com a colaboração de Grácia Lopes Lima (pela ênfase na mídia rádio, presente na primeira proposta e que foi mantida na segunda), de Fátima Yunes (que estabeleceu o contato com Dirce Gomes, então coordenadora do "Projeto Vida”) e Márcia Coutinho Jimenez (pelas sugestões relacionadas ao aspecto cultural da produção midiática e ao papel do estudante enquanto ator do processo de mediação tecnológica).
} 
uma parceria entre o NCE-USP e o "Projeto Vida," setor da Secretaria Municipal de Educação que já compreendia o projeto "Escola Aberta" (responsável por incentivar e viabilizar ações educativas, esportivas e culturais nas unidades escolares abrindo-as para a comunidade durante os finais de semana). Com o avanço das negociações, em 2001, o “educom.rádio” tornou-se o segundo programa dentro do "Projeto Vida”.

Apesar de o “Projeto Vida” já possuir, naquela época, o status de “política pública” na administração municipal, o “educom.rádio”, no entanto, não era compreendido desta forma pelas autoridades. Tratava-se de um projeto "especial" encaixado no "Projeto Vida", entrando nas escolas pela via da política da prevenção da violência. Entre agosto de 2001 e julho de 2004, período em que as equipes do NCE-USP foram às escolas para desenvolver atividades práticas e teóricas, o “educom.rádio” manteve esta condição. Ao longo do $2^{\circ}$ semestre de 2004, o projeto foi transferido para a DOT (Diretoria de Orientação Técnica), passando, pela primeira vez, a ser entendido como uma prática de interesse da área da “educação formal”. Tratava-se assim do primeiro sinal de que a proposta passava a ser considerada de interesse para as políticas públicas municipais.

Do lado da universidade, o projeto ganhou espaço acadêmico na condição de curso de “extensão universitária”, pois os professores e funcionários cursistas eram certificados pela USP com três títulos referentes aos três módulos de 32 horas que compunham o programa.

Ao longo da execução do projeto houve alguns momentos de atritos institucionais quando o "Projeto Vida” detectava que os cursistas do “educom.rádio” associavam o projeto mais à Universidade de São Paulo do que ao “Projeto Vida” e, conseqüentemente, à Secretaria de Educação da Prefeitura de São Paulo. Apesar de todas as dificuldades de realização de grandes projetos em parceria com o poder público, podemos afirmar, alguns anos depois, que por sua abrangência (três anos e meio de capacitação e atendimento 
presencial a quase nove mil pessoas vinculadas às 455 escolas de Ensino Fundamental) o “educom.rádio” pode, sim, ser considerado um projeto de política pública.

A duração oficial do projeto compreendeu o período entre agosto de 2001 e dezembro de 2004. A parceria entre o NCE-USP e a Prefeitura de São Paulo foi intermediada pela Fundação de Apoio à Universidade de São Paulo (FUSP), na qual o projeto “educom.rádio” foi registrado com o número 710 sob o nome de “Educomunicação pelas Ondas do Rádio - Construindo a Paz pela Comunicação”. O documento oficial destaca como objetivos do “educom.rádio”:

A formação de educadores e estudantes do Ensino Fundamental da Rede Pública do Município de São Paulo, para planejar e desenvolver diferentes modos de comunicação na sala de aula e no conjunto das atividades educativas, privilegiando-se nesse contexto, o emprego da linguagem radiofônica, objetivando o desenvolvimento de práticas pedagógicas solidárias e colaborativas que permitam à comunidade escolar dar respostas adequadas $e$ construtivas aos problemas da convivência diária, além de uma melhor compreensão de várias linguagens em uso na sociedade da informação ${ }^{98}$.

Para atender às 455 escolas, foi elaborado um plano de sete fases semestrais. Cada unidade escolar foi inscrita em um semestre de curso. Previu-se que a cada fase se aumentaria o número de escolas participantes. A proposta inicial, elaborada quando a administração de ensino municipal de São Paulo estava subdividida em 13 NAEs (Núcleos de Ação Educativa) previa que a $1^{\text {a }}$ fase do “educom.rádio” contemplaria duas escolas de cada NAE, a $2^{\mathrm{a}}$ fase atenderia a três escolas por NAE, a $3^{\mathrm{a}}$ fase capacitaria quatro escolas

98 - Disponível no site www.fusp.org.br. Acessado em 19/09/2003. 
por NAE e assim sucessivamente. Desta forma, as 455 escolas seriam atendidas de acordo com o seguinte cronograma ${ }^{99}$ :

\begin{tabular}{|c|c|c|}
\hline Fase & Período & Escolas \\
\hline $1^{\mathrm{a}}$ fase & $2^{\circ}$ semestre de 2001 & 26 \\
\hline $2^{\mathrm{a}}$ fase & $1^{\circ}$ semestre de 2002 & 39 \\
\hline $3^{\mathrm{a}}$ fase & $2^{\circ}$ semestre de 2002 & 52 \\
\hline $4^{\mathrm{a}}$ fase & $1^{\circ}$ semestre de 2003 & 65 \\
\hline $5^{\mathrm{a}}$ fase & $2^{\mathrm{o}}$ semestre de 2003 & 78 \\
\hline $6^{\mathrm{a}}$ fase & $1^{\circ}$ semestre de 2004 & 91 \\
\hline $7^{\mathrm{a}}$ fase & $2^{\circ}$ semestre de 2004 & 104 \\
\hline
\end{tabular}

No entanto, dois fatores levaram o NCE-USP a alterar o cronograma previsto:

- as mudanças administrativas da Secretaria de Educação que resultaram, entre a $5^{\mathrm{a}} \mathrm{e}$ a $6^{\text {a }}$ fases do projeto, na extinção dos 13 NAEs para a constituição de 31 Coordenadorias de Ensino;

- $\quad$ as turbulências do período eleitoral do $2^{\circ}$ semestre de 2004.

Em virtude destes fatores, foi necessário remanejar o número de escolas atendidas em algumas fases, principalmente no último ano do projeto, com aumento na quantidade de escolas atendidas na $6^{\text {a }}$ fase e diminuição de EMEFs capacitadas na última fase. Desta forma, no primeiro semestre de 2004, o NCE-USP chegou a atender 17 pólos simultaneamente em um mesmo sábado de capacitação, capacitando 123 escolas.

No campo da Educomunicação, o “educom.rádio” mantém o recorde de projeto de maior abrangência nacional, tendo promovido 840 palestras, 420 workshops e 840 oficinas de produção midiática ${ }^{100}$, durante os 1008 encontros presenciais de 8 horas cada.

99 - NCE-USP, Boletim O Educomunicador, num.24, São Paulo, 2004, p.1. Disponível em www.usp.br/educomradio/download/boletim03.pdf. Acessado em 14/10/2006

100 - NCE-USP, Boletim O Educomunicador, Num.24, São Paulo, 2004, p.3. Disponível em http://www.usp.br/educomradio/download/boletim24.pdf. Acessado em 14/10/2006. 


\begin{tabular}{|c|c|c|c|c|}
\hline Fase & Período & Escolas & Pólos & Encontros \\
\hline $1^{\mathrm{a}}$ fase & $2^{\circ}$ semestre de 2001 & 26 & 5 & 60 \\
\hline $2^{\mathrm{a}}$ fase & $1^{\circ}$ semestre de 2002 & 40 & 13 & 156 \\
\hline $3^{\mathrm{a}}$ fase & $2^{\circ}$ semestre de 2002 & 55 & 13 & 156 \\
\hline $4^{\text {a }}$ fase & $1^{\circ}$ semestre de 2003 & 65 & 13 & 156 \\
\hline $5^{\mathrm{a}}$ fase & $2^{\circ}$ semestre de 2003 & 78 & 13 & 156 \\
\hline $6^{\mathrm{a}}$ fase & $1^{\circ}$ semestre de 2004 & 123 & 17 & 204 \\
\hline $7^{\mathrm{a}}$ fase & $2^{\circ}$ semestre de 2004 & 68 & 10 & 120 \\
\hline \multicolumn{2}{|r|}{ TOTAIS } & 455 & 84 & 1008 \\
\hline
\end{tabular}

Entre estudantes, professores, funcionários e membros da comunidade escolar, o projeto atendeu presencialmente a 8.636 cursistas $^{101}$ :

\begin{tabular}{|c|c|c|}
\hline Professores e funcionários & 5.200 & $60,2 \%$ \\
\hline Estudantes & 2.861 & $33,1 \%$ \\
\hline Membros da comunidade & 575 & $6,6 \%$ \\
\hline TOTAL & $\mathbf{8 . 6 3 6}$ & $100 \%$ \\
\hline
\end{tabular}

O programa pedagógico era composto por doze encontros presenciais, oferecidos aos sábados, com oito horas de atividades, das 8 às 17 horas (com pausa para almoço), totalizando 96 horas. O curso estava dividido em três módulos de quatro encontros cada. Os professores e funcionários que participavam do curso registrando freqüência superior a 75\% foram certificados pela USP, o que garantia direito à reclassificação na carreira com aumento em seus respectivos salários. Os estudantes, por sua vez, se inscreviam no projeto mediante convite e permaneciam no "educom.rádio" devido ao interesse que o curso despertava, pois não ganhavam qualquer tipo de bonificação, participando por adesão. Havia um limite de inscrições, por escola, de até dez estudantes, doze professores e/ou funcionários, além de três membros da comunidade. Durante as atividades, cada um dos

101 - ibidem 
participantes era conscientizado de seu papel como multiplicador, em suas escolas, das idéias e das práticas vivenciadas no projeto.

As escolas participantes de cada fase se reuniam em um pólo sediado em uma das unidades escolares que recebia os cursistas das escolas próximas. Ao longo dos doze sábados de capacitação, uma equipe treinada pelo NCE-USP desenvolvia atividades práticas e teóricas com os cursistas, alternando momentos em que todos estavam juntos e outros em que havia separação entre alunos e professores, ou, mesmo, divisão por escola, ou, ainda, atividades em grupos mistos.

Nos pólos, a equipe enviada pelo NCE-USP promovia um programa que compreendia atividades de leitura crítica da mídia; dinâmicas de estímulo ao trabalho cooperativo; oficinas e workshops de produção radiofônica; realização de programas de rádio com uso de gravadores de mão e aparelhos de som; desenvolvimento de jornal-mural; realização de "story-boards" (desenhos em que se planeja como seria gravado determinado roteiro de cinema ou TV). Para o NCE-USP, a mais importante das atividades era o conjunto de oficinas destinadas à elaboração de um planejamento conjunto entre alunos, professores e membros da comunidade para introdução do rádio na escola. Para subsidiar os cursistas na realização de seus planejamentos e na elaboração de pautas para os programas radiofônicos eram oferecidos palestras e bate-papos com especialistas de temas relacionados à compreensão da Educomunicação, à área de Comunicação e também a temas considerados transversais nos parâmetros curriculares como "Pluralidade Cultural e Educomunicação", “Meio Ambiente e Educomunicação”, “Protagonismo Juvenil e Educomunicação”, “Saúde e Educomunicação” e “Linguagens da Comunicação”.

As equipes enviadas pelo NCE-USP às escolas eram compostas por: 
- um articulador: figura que respondia pelo NCE-USP no pólo; tratava de questões de infra-estrutura e logística com os representantes das coordenadorias regionais da Secretaria de Educação e com a direção da escola-pólo; acompanhava as palestras oferecidas aos grupos dos professores; mediava as oficinas de elaboração do planejamento do uso do rádio na escola feito por docentes e funcionários; conduzia as principais atividades nos momentos em que todos os cursistas das diferentes escolas do pólo estavam reunidos em um mesmo espaço.

- um assistente de articulação: profissional que auxiliava o articulador na execução de suas funções, estabelecendo a ponte e a troca de informações entre as atividades que o articulador estava desenvolvendo com o grupo dos professores e as que os mediadores estavam realizando com os estudantes. Zelava pelo controle do tempo para viabilizar que todas as atividades planejadas para o dia pudessem ser realizadas.

- Um grupo de mediadores, sendo um por escola participante: essa figura, anteriormente designada como “capacitador”, era a de um educomunicador que desenvolvia atividades teóricas e práticas com os grupos de estudantes, mediava as oficinas de elaboração do planejamento do uso do rádio na escola feito pelos alunos e, posteriormente, as oficinas em que estes reuniam-se com os professores que também traziam sua proposta e buscavam elaborar um planejamento único, junto com os estudantes, para o uso do rádio na escola.

De acordo com o contrato do projeto “educom.rádio” firmado com a Prefeitura de São Paulo, cada escola participante deveria receber um equipamento integrado com as mesmas funções de uma pequena emissora de rádio, capaz de produzir programas (usando duplo- 
deck, aparelho de CD, mesa de som, microfones) e transmitir as produções (ao vivo ou gravadas) para as caixas acústicas sintonizadas apenas na freqüência da antena do equipamento. Neste processo, a transmissão ocorre sem fio: basta ligar a caixa acústica na tomada para receber o som que é emitido a partir do equipamento. Não se trata de uma “rádio pirata”, mas de uma "rádio restrita”, pois as transmissões ocorrem na freqüência FM 240,3 MHz e, portanto, não interferem nas programações de rádios comerciais que ocupam a faixa FM entre 87,9 MHz e 107,9 MHz. Além disso, a transmissão dessa rádio restrita que muitas escolas receberam atinge um raio de cerca de apenas 100 metros ao redor do ponto de instalação da antena transmissora.

O kit de rádio do projeto incluía cinco gravadores de mão, três microfones (um com fio e dois sem fio), um aparelho transmissor uma antena, 10 caixas acústicas receptoras do sinal da antena do aparelho, um rack contendo mesa de som de oito canais, um aparelho duplo deck de fitas cassete, um aparelho leitor e gravador de CD.

Pelo contrato firmado com a Prefeitura de São Paulo, cada escola deveria receber seu kit completo dos equipamentos durante a fase semestral em que estavam sendo capacitadas pelo NCE-USP nos doze encontros presenciais aos sábados. Estava previsto que parte da capacitação oferecida pelas equipes do NCE-USP contemplaria atividades de prática radiofônica com o uso do equipamento que as escolas teriam à sua disposição. No entanto, ocorreram muitos problemas de atraso na entrega dos equipamentos para as escolas: devido a problemas nas licitações, a maioria das unidades só recebeu seu kit de rádio meses após as 96 horas presenciais de curso. E o que é pior: cerca de duzentas das 455 escolas nem sequer chegaram a receber os equipamentos até a entrega da presente dissertação.

Para tentar solucionar parte dos problemas acarretados pelo atraso dos equipamentos, o NCE-USP teve que elaborar novas oficinas e atividades práticas de produção radiofônica 
de modo a trabalhar, muitas vezes, com recursos técnicos mais limitados, porém desenvolvendo na teoria e na prática os principais conceitos relacionados à linguagem radiofônica. Além disso, o NCE-USP criou uma equipe extra de “capacitação técnica” para atender às escolas assim que estas recebessem os equipamentos de rádio oferecendo um treinamento presencial de seis horas na própria unidade escolar. Eram realizadas duas capacitações de três horas atendendo turmas de até 15 pessoas, em dia e horário determinado por cada escola. Cada agente capacitado era conscientizado sobre o seu papel de multiplicador na escola: se o conhecimento da operação do equipamento não for democratizado, o mesmo pode cair em desuso ou tornar-se "propriedade particular" de alguns, alertava a “Agenda do educom.rádio número 2”, material impresso informativo produzido pelo NCE-USP e distribuído aos cursistas.

Os capacitadores treinados e enviados pelo NCE-USP às escolas tinham a difícil missão de não deixar transparecer a impressão de que a técnica (aprender a usar os equipamentos) estava dissociada da teoria (a fase semestral do “educom.rádio”). As avaliações dos cursistas em relação ao projeto revelaram que para professores e alunos estava claro que os

problemas de logística e infra-estrutura diziam respeito à Secretaria de Educação da Prefeitura de São Paulo e não à proposta pedagógica do NCE-USP.

\section{2 - Perfil dos participantes}

É fundamental compreender e analisar as principais características dos três anos e meio de capacitação presencial do projeto “educom.rádio”, pois as atividades de formação 
tiveram influência direta tanto na conscientização teórica da comunidade escolar como na continuidade das práticas educomunicativas e das produções radiofônicas após o final do contrato do projeto com a Prefeitura de São Paulo, no final de 2004.

Antes de mais nada, é importante conhecermos melhor quem eram esses quase nove mil cursistas que passaram pelo “educom.rádio”. Ao tentar identificar o perfil dos professores e estudantes participantes deparamo-nos com a constatação de que os pólos eram muito heterogêneos tanto em comparação com outros grupos da mesma fase quanto em relação a fases distintas. Um mesmo pólo chegava a agrupar escolas com diferentes graus de envolvimento. As principais diferenças de perfis dos estudantes e professores cursistas diziam respeito aos seguintes aspectos:

- Escolha dos estudantes participantes: cada escola criou seus próprios critérios de seleção e indicação de até dez estudantes para participarem da capacitação presencial aos sábados. Havia três tipos de seleção predominantes:

a) Abertura de vagas para que todos os alunos que tivessem interesse pudessem se inscrever livremente. Quando havia mais de dez interessados optava-se por processos como eleição entre os estudantes ou sorteios;

b) Convites aos alunos que eram considerados os "melhores” na avaliação de professores e coordenadores levando em consideração as notas dos estudantes, e também disciplina e comportamento;

c) Convites aos alunos que eram considerados os "piores" na avaliação de professores e coordenadores levando em consideração não só as notas dos estudantes, mas principalmente os problemas de indisciplina e de mau comportamento. Alguns professores e coordenadores entendiam o 
“educom.rádio” como a última “esperança de salvação” para os alunos indisciplinados e violentos.

- Interesse e envolvimento:

a) Escolas com professores e coordenadores cursistas que eram simpáticos ao projeto e receptivos a novas práticas e idéias. Muitas unidades escolares contaram com a participação de diretores e coordenadores na elaboração do planejamento para uso da rádio na escola;

b) Escolas com professores e coordenadores cursistas extremamente questionadores e contrários ao projeto. Muitas escolas não tinham sequer um representante da direção ou coordenação pedagógica entre o grupo de cursistas, o que dificultava a realização e viabilização do planejamento de uso da rádio na escola sem o consentimento e a participação das instâncias superiores que se mantinham hierarquicamente no poder adotando uma postura verticalizada e distante.

Apesar destas diferenças que caracterizaram a heterogeneidade do projeto, é possível constatar e agrupar algumas semelhanças de perfis dos estudantes e professores cursistas. Não se trata de uma generalização, mas de características atribuídas à maioria (e não à totalidade) das escolas participantes:

- Os estudantes eram ouvintes assíduos de emissoras FM, enquanto o grupo de professores e funcionários era constituído não só de ouvintes de emissoras FM, mas também de AM; 
- Estudantes e professores cursistas chegavam ao projeto com pouco conhecimento sobre os processos de realização de produtos audiovisuais e as etapas de criação e produção utilizadas pelos meios de comunicação de massa;

- As escolas participantes não trabalhavam de forma regular e contínua com algum recurso midiático nem realizavam produtos comunicativos (jornal, jornal-mural, fanzine, site, vídeo, programa de rádio, etc). Havia algumas atividades isoladas vinculadas a determinada disciplina, a projetos de um professor, etc;

- Baixo índice de participação de membros da comunidade tanto nos grupos de crianças e jovens como nos de adultos. Das 1.365 vagas disponíveis (três por escola) apenas 575 foram ocupadas. Muitas escolas não tinham sequer um membro da comunidade participando do projeto e todos os seus cursistas possuíam vínculo direto com a instituição de ensino (professor, funcionário ou aluno);

- Os estudantes se inscreviam no projeto entendendo-o mais como um "curso de rádio” do que como um projeto educativo. Crianças e jovens levavam mais objetos, instrumentos musicais e CDs do que os adultos. Já os professores tinham uma visão mais abrangente do “educom.rádio” e o entendiam, já de início, mais como um projeto educativo do que como um curso de rádio;

- Os alunos chegavam ao curso sem ter conhecimentos sobre o que era o PPP (Projeto Político-Pedagógico) da escola. Muitos confessaram que só souberam que professores e coordenadores faziam anualmente o PPP graças ao "educom.rádio”, por meio das oficinas de realização de planejamento de uso da rádio na escola em conjunto com os adultos. 


\section{3 - Objetivos, estratégias e parcerias}

Para difundir as idéias e práticas educomunicativas, o projeto “educom.rádio” desenvolveu, avaliou e reformulou suas estratégias de modo a atingir seus objetivos e enfrentar muitos obstáculos como: a precariedade do ensino público; o “atraso" e o “despreparo” da Educação para lidar com as novas tecnologias e os meios de informação; as burocracias pertinentes a uma parceria entre duas esferas públicas (uma universidade estadual e uma secretaria municipal) intermediada por uma fundação (a FUSP - Fundação de Apoio à Universidade de São Paulo) e a grande quantidade de escolas e cursistas atendidos.

Nesse sentido, pretendemos analisar as principais características de viabilização e realização do projeto bem como sua relação com a adoção dos conceitos e das práticas educomunicativas por parte dos cursistas participantes.

O primeiro aspecto a ser destacado diz respeito ao fato de que o projeto não utilizou a mídia de massa para difundir conceitos relacionados à Educomunicação. Optou-se pela comunicação pessoal, indispensável neste caso, devido à novidade deste campo de intervenção social, à complexidade e amplitude dos temas trabalhados e à necessidade de atividades práticas sob orientação de profissionais previamente capacitados.

No caso do “educom.rádio”, a própria teoria de Educomunicação exige que projetos dessa área, por coerência, envolvam a comunicação pessoal, ao menos em parte do processo, para desenvolver na prática a adequação ao contexto sócio-cultural de cada região e o fortalecimento das relações de trabalho em grupo. O contato pessoal com os cursistas de cada escola também permitiu orientações e acompanhamentos 
“personalizados”, pois em uma mesma região era possível encontrar escolas com realidades díspares.

Durante a realização do projeto foi criado um site (www.usp.br/educomradio) para atender concomitantemente ao público interno (cursistas e equipe do NCE-USP) e externo (pesquisadores, jornalistas, etc... que desejassem conhecer melhor o projeto).

Foi um canal de comunicação que pôde disponibilizar produções radiofônicas dos cursistas, fotos dos encontros presenciais, acesso a textos acadêmicos e a notícias relacionadas ao campo da Educomunicação, algumas delas escritas e enviadas por cursistas.

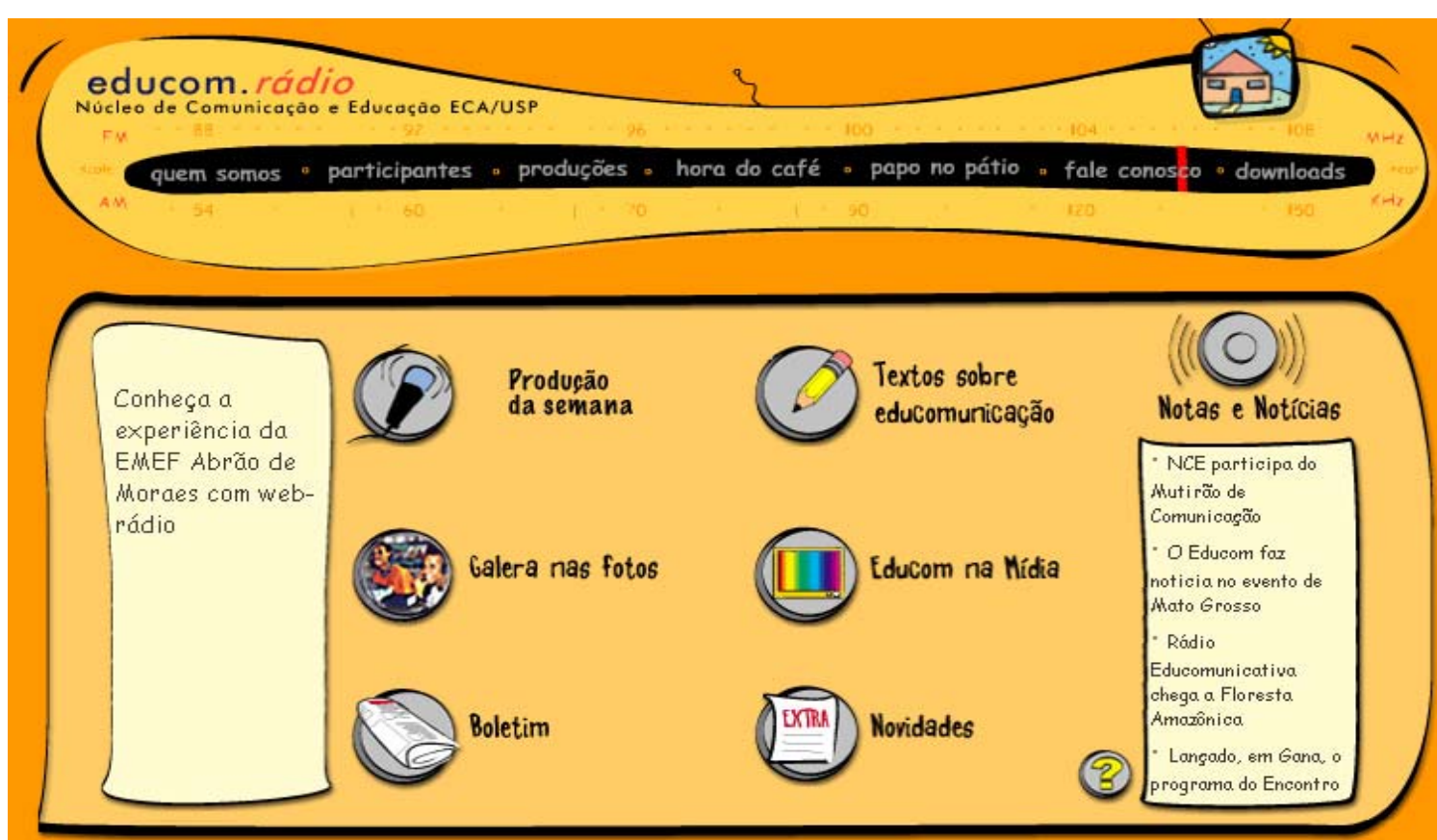

Tela inicial (home page) do site do projeto “educom.rádio” (acima).

Seção de audição dos programas radiofônicos das escolas (ao lado).

$\begin{array}{lll}\text { Eata } & \text { Internet Rápida }\end{array}$


Podemos apontar como principais características do projeto “educom.rádio”:

- Objetivos: introduzir a Educomunicação nas escolas públicas visando à melhoria das relações de comunicação em âmbito escolar, ao aprimoramento da expressa comunicativa de crianças e jovens, à prevenção e diminuição da violência, promovendo, assim, uma cultura de paz;

- Agentes de mudança: NCE-USP em parceria com a Secretaria Municipal de Educação da Prefeitura de São Paulo (por meio do “Projeto Vida”);

- Público-alvo: professores, funcionários, alunos e membros da comunidade das escolas municipais de Ensino Fundamental da cidade de São Paulo;

- Canais de contato: comunicação pessoal dos cursistas com a equipe capacitada e enviada pelo NCE-USP; site do projeto e materiais de apoio como boletins impressos;

- Estratégias de mudança: contextualizar e convencer os cursistas sobre a importância da Educomunicação; capacitá-los, durante os encontros presenciais, para que passassem a agir como educomunicadores, aprendendo a analisar e produzir conhecimento utilizando os meios de comunicação para que, após o curso, pudessem se tornar multiplicadores em suas escolas, formando novos educomunicadores e colocando a rádio para funcionar de acordo com os princípios democráticos, dialógicos e participativos da Educomunicação. Desta forma, promoveriam a troca da violência pelo diálogo e pela expressão comunicativa dos jovens, melhorando, assim, as relações de comunicação na escola. 
Trata-se de um projeto com objetivos que propõem resultados dificilmente mensuráveis, como a diminuição da violência pela promoção da comunicação. Não é fácil identificar claramente, nas escolas que já participaram e implantaram o uso do rádio, como o projeto contribuiu para a diminuição da violência por vários motivos:

- nem sempre é possível envolver, na prática, toda a comunidade escolar em torno do projeto, da rádio, da criação de ecossistemas comunicativos; ou seja, não são todas as pessoas que estão envolvidas diretamente com as práticas educomunicativas;

- outros projetos e iniciativas, dentro da escola e/ou na comunidade ao redor do estabelecimento de ensino podem/poderiam contribuir para a diminuição da violência paralelamente ao “educom.rádio”;

- há rotatividade de alunos, professores e funcionários nas escolas;

- não é possível ter dados de como estariam os índices de violência na escola se a mesma não tivesse participado do projeto “educom.rádio” (situação hipotética).

Quanto aos cursistas participantes, percebemos que se trata de um leque amplo, que pode incluir desde crianças até idosos. Verificamos também diferenças sócio-culturais de acordo com as áreas de localização em uma cidade tão grande e desigual como São Paulo. Ciente destas variações, o NCE-USP deu liberdade para que cada uma das equipes reformulasse as atividades previstas para cada sábado levando em consideração a adequação ao contexto sócio-cultural de cada grupo e às faixas etárias envolvidas (principalmente com os alunos). A valorização do contexto local para uma aprendizagem mais eficaz, que teve sua base em Paulo Freire, é uma das características da Educomunicação e não poderia, portanto, ser descartada da prática do projeto que buscou atingir seus objetivos neste estreito limiar existente entre a manutenção de um padrão para 
todos os grupos (padronização, unidade do projeto) e a abertura de espaço para os ajustes e mudanças de acordo com o contexto local (personalização).

O NCE-USP teve a preocupação de tentar envolver no projeto todas as instâncias de uma escola (do aluno ao diretor) por perceber a necessidade de desenvolver na prática a aproximação entre educador e educando em atividades colaborativas, democráticas, dialógicas, onde há horizontalidade de relações. Durante a produção de um programa de rádio, por exemplo, alunos, professores e diretor tinham a mesma importância hierárquica e poder de decisão ou podiam, então, definir democraticamente quem executaria quais funções. Muitas vezes, o docente aprendia com o estudante e ambos percebiam que um não conhecia bem o outro e ainda não haviam se dado a possibilidade de trabalharem e criarem juntos.

Ficou evidente, na grande maioria dos pólos, o aumento de interesse dos cursistas ao longo dos encontros aos sábados e da clareza que adquiriram em relação às diferenças do defasado modelo de educação em comparação com as propostas da Educomunicação, que apareceram como novidade por extrapolarem o antigo conceito de realizar apenas leitura crítica dos meios na escola. Durante as avaliações com os estudantes era possível notar que percebiam paulatinamente que as idéias e práticas educomunicativas poderiam tornar o diaa-dia escolar muito mais agradável e produtivo, transformando a ida à escola em algo interessante e criativo em vez de obrigatório, mecânico e chato. Esse reconhecimento da utilidade e satisfação que o projeto lhes proporcionava garantiu a continuidade da presença da maioria dos estudantes ao longo dos sábados, pois estes eram os únicos estímulos que recebiam, afinal, a presença e participação não os bonificava com notas mais altas ou aumento salarial como ocorria com professores e funcionários. 
Estes últimos, por sua vez, muitas vezes se inscreviam no projeto (e alguns até assumiam abertamente) interessados na pontuação de suas carreiras. Tratava-se do que se chama na área de Marketing de “adoção por aquiescência”. Cabia à equipe enviada pelo NCE-USP aproveitar os sábados presenciais para conquistar estes cursistas, fazendo passálos da “adoção por aquiescência” para a “identificação”, para o “conhecimento” e, por fim, para a "internalização”, a qual garantiria que eles lutariam pela continuidade das idéias e práticas educomunicativas em sua escola. Afinal, vale ressaltar que apenas as presenças nos encontros do sábado garantiam pontuação e aumento salarial; a continuidade do projeto nas escolas não implicaria em bonificação extra na carreira. Portanto, o que faria o professor ou o funcionário esforçar-se para o planejamento, implementação e avaliação do “educom.rádio" em sua escola era o seu convencimento sobre a importância e a necessidade da adoção de idéias e práticas educomunicativas e da relevância destas para auxiliar no combate à violência e à promoção da paz, do diálogo e da integração entre as diversas instâncias da escola.

Destaca-se no "educom.rádio" o equilíbrio que o projeto tentou buscar ao longos dos três anos e meio para conciliar teoria e prática. A grande carga de informações a que os adotantes tiveram acesso pela comunicação pessoal (com palestras, bate-papos, debates, dinâmicas e atividades presenciais aos sábados) permitiu que os temas das áreas de interrelação Comunicação/Educação pudessem ser aprofundados e divididos ao longo dos encontros, evitando a superficialidade. Se a teoria trouxe como novidade a Educomunicação, a prática apresentou, por sua vez, a produção de rádio e a realização em grupos mistos de alunos, professores, funcionários gerando cumplicidade, conhecimento e aceitação do outro, pela potencialização da capacidade de expressão. Por meio da produção 
e veiculação dos programas de rádio abriu-se espaço para o extravasamento e até para a catarse, como em vários programas que ficcionalizaram a violência, por exemplo.

Analisando a influência dos parceiros do NCE-USP no projeto "educom.rádio", identificamos alguns setores que poderiam auxiliar ou afetar o êxito do projeto, como:

- Grupos de permissão e autorização (órgãos regulamentadores): parcerias com instâncias da Secretaria Municipal de Educação. O “educom.rádio” juntamente com o programa “Escola Aberta” ficou sob a administração do "Projeto Vida”. Todos os 13 NAEs (antigos Núcleos de Ação Educativa) foram contemplados logo na primeira fase com a participação de duas escolas por grupo. A cada semestre se aumentaria o número de escolas de cada NAE (três na segunda fase, quatro na terceira fase, cinco na quarta fase e assim por diante). No decorrer do projeto, no entanto, os NAEs foram extintos para a criação de 31 Coordenadorias de Educação. A equipe do NCE-USP teve, então, que reestruturar a divisão de grupos, afinal seria complicado organizar 31 pólos simultâneos aos sábados. Desde então, as escolas passaram a ser agrupadas por regiões próximas (mesclando as pertencentes a diferentes Coordenadorias de Educação). A parceria com a equipe do "Projeto Vida” e dos NAEs e, depois, das Coordenadorias, foi de fundamental importância para autorizações de usos de escolas aos sábados, oficialização do projeto, obtenção de transporte e alimentação para os cursistas, etc. No entanto, devido a diferentes vínculos políticos dos responsáveis por NAEs ou Coordenadorias, houve variados níveis de aceitações e resistências ao projeto. Além disso, as instâncias públicas municipais tornaram-se responsáveis pela compra dos equipamentos de rádio para as escolas. Conforme foi dito anteriormente, com o avanço das fases, o atraso da 
compra e da entrega dos equipamentos foi se tornando cada vez maior, em virtude, muitas vezes, de problemas de licitação;

- Grupos de apoio: para a viabilização e execução do projeto, o NCE-USP buscou em universidades, ONGs, e grupos voltados à área de comunicação popular parcerias de especialistas em linguagem radiofônica, em Comunicação e em projetos educativos. Uma estratégia muito adotada em projetos nas áreas de Educação e Cidadania é associar as ações a uma personalidade, a um nome muito conhecido. No entanto, o “educom.rádio” não teve um “padrinho” famoso que fosse reconhecido fora dos círculos acadêmicos e tivesse apelo popular. Reconhecemos que era extremamente complicado ter um nome famoso reconhecido como um “educomunicador”, e encontrar no rádio nacional uma personalidade que, além de famosa, se destacasse pela preocupação educativa, cultural e cidadã, nestes anos em que a programação radiofônica é fortemente comercial, não apresentando muitas variações de formatos além dos jornalísticos, esportivos e musicais, além de ser marcada pela carência de programas infantis e educativos;

- Grupos opositores: a princípio, o projeto não teria opositores típicos de projetos educativos (como grupos religiosos que se opõe a programas de controle de natalidade e uso de preservativo, por exemplo). A maior resistência viria de parte do público adotante, como diretores autoritários e centralizadores, professores preconceituosos em relação à mídia, além de pessoas (de algumas instâncias governamentais ou do grupo de cursistas) que encaravam o projeto como partidário acreditando que poderia transmitir nas escolas programas radiofônicos promovendo as benfeitorias da Prefeitura, fazendo propaganda partidária nas escolas. Com o andamento do projeto, o público pôde perceber que não se tratava disso, mas, pelo 
contrário, que cada escola tinha liberdade de produzir e veicular seus programas, não recebendo nenhuma produção radiofônica pronta e podendo inclusive debater e questionar ações da própria Prefeitura, a financiadora do projeto;

- Grupos de avaliação: logo de início, o projeto despertou simpatia de vereadores e políticos que apóiam iniciativas semelhantes às rádios comunitárias. Com o tempo ganhou visibilidade e repercussão, fazendo com que membros do governo municipal percebessem que o “educom.rádio” era mais do que um simples “curso”, que se tratava de um projeto de política pública que poderia inclusive provocar mudanças em grades curriculares, pois as idéias do projeto eram coerentes com a nova Lei de Diretrizes e Bases da Educação. Vereadores entraram com pedido da criação de uma lei referente ao projeto “educom.rádio” e algumas Coordenadorias de Educação solicitaram estudos para que fosse dada assessoria às escolas que já tinham participado dos encontros presenciais.

Além de avaliar o papel dos grupos de influência, é importante ressaltar que o projeto tinha um objeto tangível (o equipamento de rádio) que, por sua vez, exigia demonstração pessoal. Embora a compra do equipamento fosse de responsabilidade governamental, o NCE-USP além de passar as informações que julgasse adequadas para a compra de um modelo de equipamento coerente com os objetivos propostos, assumiu a responsabilidade de administrar os principais elementos de projetos que requerem uma apresentação ou demonstração pessoal:

- O pessoal da prestação de serviço: alguns educomunicadores que tinham familiaridade com equipamentos eletrônicos, que faziam parte do projeto (ou seja, tinham experiência de ir às escolas aos sábados e vivenciar conceitos de 
Educomunicação) foram treinados por uma equipe coordenada por um professor universitário da área de "Rádio e TV" (palestrante do projeto) para aprenderem detalhes sobre o funcionamento do equipamento e a melhor forma de transmitir as informações para o público leigo (professores e alunos);

- A apresentação da prestação de serviço: as escolas que já haviam passado pelos doze encontros aos sábados, assim que recebiam o equipamento completo junto com a instalação, podiam solicitar uma diária de “capacitação técnica” de seis horas. Uma pessoa treinada pelo NCE, ciente dos objetivos e do contexto em que seria usado aquele equipamento, explicava aos cursistas o que se podia fazer com os recursos tecnológicos disponíveis e como deveriam cuidar da manutenção dos aparelhos;

- O processo da prestação de serviço: o representante do NCE-USP ia até a escola em horário previamente agendado para contemplar dois grupos de até 15 pessoas que fossem formados, de preferência, por alunos, funcionários e professores. Além de responder às dúvidas dos cursistas, o capacitador permitia que eles testassem na prática os equipamentos.

Destaca-se o fato de a apresentação técnica não ficar dissociada do projeto: seria um erro pensar que um técnico qualquer sem familiaridade com o projeto poderia realizar a capacitação técnica ou, então, delegar esta função à empresa responsável pela entrega e instalação do equipamento. Um educomunicador que conhecesse o projeto "educom.rádio” poderia oferecer não só esclarecimentos técnicos sobre o funcionamento dos aparelhos, mas também dicas de como professores e alunos poderiam trabalhar juntos, revezar funções, que formatos de programas poderiam ser feitos, como distribuir as caixas 
acústicas de acordo com os objetivos e público-alvo de cada programa, etc. No entanto, além dos atrasos do recebimento do equipamento, muitas vezes havia demora entre a solicitação da capacitação técnica e a sua realização. Por mais que fossem preparados durante os encontros dos doze sábados a planejar a continuidade do “educom.rádio” em sua escola mesmo sem a chegada dos aparelhos (usando gravadores de mão, aparelho de som e outros equipamentos que a escola já possuía antes do projeto, ou ainda, escrevendo roteiros de futuros programas, etc) muitos cursistas esperaram o recebimento do equipamento completo para efetivamente difundir idéias e práticas educomunicativas na sua escola e capacitar outros alunos, professores e funcionários.

Analisando o “educom.rádio”, sob o ponto-de-vista dos cursistas, identificamos que os principais aspectos detectados e comentados foram:

- Contato com um novo conceito: era a primeira vez que a maioria dos cursistas ouviu falar em Educomunicação, que a princípio parecia vestir uma roupagem teórica e acadêmica, mas que trazia consigo um produto tangível, como o equipamento capaz de viabilizar uma emissora de rádio na escola, agregando uma sensação de novidade e ludismo. Tratava-se de um conceito que agregava a imagem de uma das universidades mais respeitada do país, a USP, o que além da sensação de "novidade” trazia também a "credibilidade” de que teria sido pensada, proposta e recomendada por especialistas renomados. Empiricamente, percebemos que cada segmento de público-alvo tinha expectativas iniciais diferentes em relação ao novo conceito e ao projeto. Professores o enxergavam como um curso da USP na área de Educação e os estudantes como um curso prático de rádio que ensinaria técnicas semelhantes àquelas das rádios comerciais e que poderia capacitá-los para se tornarem locutores e “DJs”, como se diz na gíria jovem. 
- Gratuidade: o curso oferecido pela Prefeitura de São Paulo era gratuito para os cursistas. No entanto, muitos projetos educativos trazem consigo os chamados “custos não-monetários” para o público-alvo. No “educom.rádio”, o “preço mais alto” apontado pelos cursistas era o de acordar extremamente cedo aos sábados (quando já acumulavam todo o cansaço de segunda à sexta) e disponibilizar seus “sábados inteiros” (saíam de casa por volta das 7h00 e retornavam por volta das 18h00) para o projeto. Muitos cursistas declararam que seus companheiros de escola não se inscreveram no projeto porque não estariam dispostos a "perderem seus sábados” em algo que ainda não conheciam bem e não tinham certeza de que valeria a pena. Para reduzir o "custo" de transporte, a Prefeitura disponibiliza veículos como “vans” ou pequenos ônibus que levavam e traziam os estudantes da escola onde estudavam para unidade escolar sede dos encontros.

- (Re)conhecimento do espaço: uma escola participante era escolhida como pólo e os cursistas das demais unidades escolares da região se dirigiam a ela aos sábados. O agrupamento de escolas próximas facilitava a participação dos cursistas. Os grupos de encontros eram pulverizados pela cidade a fim de evitar que integrantes das escolas que não eram pólo tivessem que se deslocar por grandes distâncias. A posterior capacitação técnica para utilização do equipamento era feita em cada escola na melhor data proposta pelos cursistas. As equipes do NCE-USP conseguiam aproveitar uma característica de logística (impossibilidade de realizar encontros por escola e ter que reunir mais de uma em cada pólo) para gerar momentos de troca de experiências e criação de novos vínculos e contatos entre cursistas que viviam realidades sócio-demográfico-culturais parecidas, mas não se conheciam. 
- Divulgação e conscientização: a Educomunicação abre espaço para as novas tecnologias, no entanto, não exclui a importância da comunicação pessoal. A promoção do projeto (de suas idéias e práticas) era feita pessoalmente. A equipe do NCE-USP em cada pólo distribuía materiais de divulgação como boletins impressos para os cursistas e veiculava vídeos produzidos pela equipe do setor de "Memória Audiovisual” do NCE-USP como institucionais e documentário contando a história de jovens que já haviam participado do “educom.rádio”. Nos encontros aos sábados, as equipes do NCE-USP ainda socializavam e divulgavam para os cursistas materiais sobre o projeto que circularam pela imprensa: exibição de matérias na TV, notícias de jornais e revistas, etc. Havia ainda divulgação do site do projeto, por meio do qual era possível interagir e contribuir enviando textos e fotos. A partir da $5^{\mathrm{a}}$ fase $\left(2^{\circ}\right.$ semestre de 2003), o NCE-USP tornou semestral uma importante estratégia de promoção: a realização dos Simpósios Brasileiros de Educomunicação numa data pré-marcada simultaneamente em todos os grupos que participavam de determinada fase. Era um dia especial em que se convidava especialistas, personalidades, autoridades e ex-cursistas que já haviam participado do projeto e aceitavam contar suas experiências com a rádio na escola, além de abrir espaço para não-cursistas que tinham a curiosidade de conhecer a Educomunicação. Estes eventos cumpriam um duplo papel: divulgar a Educomunicação para quem ainda não a conhecia e também aprofundar a divulgação internamente entre os cursistas da própria fase, explicitando tanto o “gigantismo” do projeto como suas conseqüências positivas nos locais onde foi implementado. Os simpósios ajudaram a fortalecer as marcas “educom” e “educomunicação”, divulgando não só esses dois neologismos, mas associando a 
eles idéias e práticas. Ao longo das atividades aos sábados, os cursistas eram estimulados a realizar programas de rádio e cartazes sobre o próprio projeto. Esses materiais (principalmente os cartazes) eram distribuídos nas respectivas escolas, ajudando a divulgar o "educom.rádio" para quem não conhecia o projeto e promovendo o essencial "boca-a-boca” entre cursistas e não-cursistas.

É importante destacar que o NCE-USP inovou, perante os cursistas, ao introduzir a figura e a postura do mediador que, diferentemente do que ocorre em muitos outros cursos e projetos, não desenvolviam meras "oficinas performáticas", mas sim um processo de mediação entre os conteúdos e atividades propostas buscando envolver as diversas instâncias da escola. Os cursistas não precisaram se deslocar para realidades fora do seu contexto sócio-cultural (como universidades, por exemplo), pois os profissionais capacitados pelo NCE-USP iam até a região da escola-pólo e das unidades escolares próximas. Os mediadores foram capacitados pelo NCE-USP para conviverem com os conflitos do local onde iriam atuar e propor soluções baseadas no diálogo. O projeto “educom.rádio" entrou nas escolas com o objetivo de criar uma nova cultura de práticas educomunicativas desenhando uma experiência cultural que, a partir das últimas fases, culminava em um simpósio para atingir e envolver também a comunidade.

\section{4 - A continuidade das idéias e das práticas}

Como foi explicado anteriormente, algumas semanas após o término da formação presencial do "educom.rádio" nas escolas, em dezembro de 2004, foi sancionada pela então 
prefeita Marta Suplicy a Lei 13.941 instituindo o "Programa Educom - Educomunicação pelas ondas do rádio”. Em junho do ano seguinte foi eleita a primeira diretoria do "Comitê Gestor da Lei Educom”. O professor Carlos Alberto Mendes de Lima, que havia sido cursista do projeto em 2002, tornou-se presidente do Comitêt ${ }^{102}$, e visitou nos anos de 2005 e 2006 cerca de duzentas escolas que participaram do “educom.rádio”, realizando inúmeras capacitações técnicas para as escolas que haviam recebido o equipamento. Buscou formas de viabilizar a aquisição de equipamentos semelhantes para as escolas que dispunham de poucos recursos tecnológicos para a realização de programas de rádio, tendo proposto e implementado algumas ações para conciliar as práticas educomunicativas radiofônicas com atividades do setor de "Informática Educativa”, de modo a contemplar o uso do computador tanto na produção radiofônica (principalmente nas etapas de edição, sonorização e pós-produção) como também na veiculação (por meio da criação de webrádios das escolas).

Apesar do esforço de professores como Regina Célia Lico Suzuki, Jarbas Mazzariello e Carlos Alberto Mendes de Lima que, a partir da Diretoria do Ensino Fundamental da Secretaria da Educação, continuaram apoiando o projeto em 2005 e em 2006, com resultados efetivos, constatamos, pelo que nos foi dado verificar ao longo da pesquisa, que, para a política pública da Secretaria da Educação, o “educom.rádio” foi um "bom" projeto, incapaz, contudo, de motivar o estabelecimento de nova parceria entre a prefeitura e o NCE-USP para um acompanhamento contínuo das escolas (principalmente daquelas que haviam participado das primeiras fases do projeto) e, especialmente, para viabilizar a

\footnotetext{
102 - A vice-presidência foi assumida pelo Prof. Ismar de Oliveira Soares, representante do setor universitário, no Comitê, e a Secretaria, pela jornalista Terlânia Bruno, representante, no Comitê, do Sindicato de Jornalistas do Estado de São Paulo e funcionária da Oboré, empresa que atua em projetos de comunicação popular.
} 
chegada, às 200 escolas das fases 6 e 7, do kit do equipamento de rádio a elas devido e prometido.

Tendo ciência das dificuldades de sobrevivência de projetos realizados em parceria com o poder público, o NCE-USP desenvolveu algumas estratégias visando a garantir a motivação dos cursistas para a continuidade das idéias e práticas propostas no “educom.rádio”, após o encerramento do contrato com a Prefeitura de São Paulo, em dezembro de 2004. Em todas as fases do projeto, mas principalmente durante o ano de 2004, as equipes enviadas pelo NCE-USP aos pólos foram orientadas a atribuir aos cursistas a "co-autoria” do projeto, designando-os como os principais responsáveis pela sua continuidade independentemente do resultado do processo eleitoral vivido pela cidade no segundo semestre de 2004, adotando o seguinte discurso: “o projeto não é da USP, não é da Prefeitura, é de vocês, é de quem abraçar as idéias e torná-las realidade na sua escola e na sua comunidade”.

Essa conscientização dos cursistas relacionava-se principalmente ao papel de multiplicadores que estes passariam a desenvolver em suas respectivas escolas a fim de implementar e fortalecer as práticas educomunicativas capacitando outros alunos, professores e funcionários para o conhecimento dos conceitos da Educomunicação e dos elementos da técnica e da linguagem da produção radiofônica.

Além das iniciativas do Comitê Gestor também foi possível constatar ações visando à continuidade do projeto que partiram de várias comunidades escolares e da sociedade civil. Em algumas regiões, houve sugestões levantadas e aprovadas em assembléias do “Orçamento Participativo" e "Orçamento Participativo Criança” para financiamento e apoio da continuidade das práticas difundidas durante o projeto "educom.rádio", numa 
demonstração de aprovação ao projeto e de compreensão do seu caráter educativo e cidadão.

Para finalizar esta análise vale ressaltar que o maior desafio a ser superado é o do reconhecimento e da transformação efetiva dos conceitos e das práticas do "educom.rádio" em política pública na cidade de São Paulo (com apoio governamental independentemente da gestão partidária) para evitar que bons projetos e ações que inter-relacionem Comunicação e Educação sejam viabilizados apenas em atividades extracurriculares ou dependam exclusivamente de ações isoladas de ativistas e de ONGs.

A explicitação e análise da concepção e implementação do “educom.rádio”, objeto do presente capítulo, teve como objetivo evidenciar e entender o contexto e as diretrizes que nortearam as produções radiofônicas, estas, sim, nosso objeto específico de pesquisa.

As análises dos programas de rádio merecem capítulos à parte: discorreremos no capítulo V sobre as produções radiofônicas realizadas durante o “educom.rádio” e, depois, no capítulo VI, sobre os programas produzidos nas escolas após a capacitação presencial do projeto, finalizada em 2004. Antes disso, é importante, no próximo capítulo, discutir e conhecer melhor o veículo rádio, suas características e linguagens, bem como sua relação histórica com a Educação ao longo dos tempos. 


\section{Capítulo 4}

\section{O rádio no “educom”}

O rádio é a escola dos que não têm escola. É o jornal de quem não sabe ler; é o mestre de quem não pode ir à escola; é o divertimento gratuito do pobre; é o animador de novas esperanças, o consolador dos enfermos e o guia dos sãos - desde que o realizem com espírito altruísta e elevado.

(Edgard Roquette-Pinto, durante discurso na Rádio Nacional, em 1923)

\section{1 - Rádio e Educação}

Uma das primeiras evidências da inter-relação rádio/educação data de 1932, ano em que um grupo de educadores, entre os quais estava Roquette-Pinto, lançou o "Manifesto dos

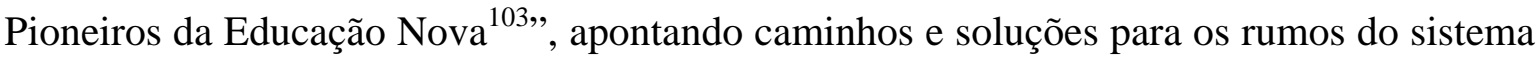
de ensino. De acordo com o documento:

a escola deve utilizar, em seu proveito, com a maior amplitude possível, todos os recursos formidáveis, como a imprensa, o disco, o cinema e o rádio, com que a ciência, multiplicando-lhe a eficácia, acudiu à obra de educação e cultura e que assumem, em face das condições geográficas e da extensão territorial do país, uma importância capital. À escola antiga, presumida da

\footnotetext{
103 - Assinaram o documento os seguintes educadores: Fernando de Azevedo, Afrânio Peixoto, A. de Sampaio Doria, Anísio Spinola Teixeira, M. Bergstrom Lourenço Filho, Edgard Roquette-Pinto, J. G. Frota Pessoa, Julio de Mesquita Filho, Raul Briquet, Mario Casassanta, C. Delgado de Carvalho, A. Ferreira de Almeida Junior, J. P. Fontenelle, Roldão Lopes de Barros, Noemy M. da Silveira, Hermes Lima, Attilio Vivacqua, Francisco Venâncio Filho, Paulo Maranhão, Cecília Meirelles, Edgar Sussekind de Mendonça, Armanda Alvaro Alberto, Garcia de Rezende, Nóbrega da Cunha, Paschoal Lemme e Raul Gomes.
} 
importância do seu papel e fechada no seu exclusivismo acanhado e estéril, sem o indispensável complemento e concurso de todas as outras instituições sociais, se sucederá a escola moderna aparelhada de todos os recursos para estender e fecundar a sua ação na solidariedade com o meio social, em que então, e só então, se tornará capaz de influir, transformando-se num centro poderoso de criação, atração e irradiação de todas as forças e atividades educativas $^{104}$

Há mais de sete décadas, educadores de renome já constatavam que a escola se encontrava fechada às novidades das tecnologias de comunicação. O próprio rádio, que estava completando apenas uma década de existência no país, foi apontado como um meio que poderia ser incorporado pela "escola moderna” (como chamaram) contribuindo para o desenvolvimento de atividades e programas de cunho educativo.

Sete décadas depois, o manifesto de 1932 ainda parece atual. Constatamos que a proposta de uso dos “recursos formidáveis” em proveito da escola não se concretizou de forma abrangente. Até mesmo o rádio, com mais de oitenta anos de existência no país e intrinsicamente ligado à história do Brasil no século XX, ainda não foi incorporado pela maioria das instituições de ensino.

Ao realizar uma abordagem histórica do potencial educativo do rádio podemos constatar que a primeira aproximação deste meio com a escola partiu da Comunicação e não da Educação. A relação rádio/educação é tão antiga quanto a história deste veículo de comunicação. Na década de 20, era possível ouvir transmissões de palestras, aulas de Língua Portuguesa, História do Brasil, Geografia, Física, Química e cursos práticos sobre

\footnotetext{
104 - Fernando de AZEVEDO. A reconstrução educacional do Brasil. Ao Povo e ao Governo. Manifesto dos Pioneiros da Educação Nova. Rio de Janeiro: 1932, p.70-71
} 
rádio, telegrafia, telefonia e silvicultura. Com um estilo mais formal, estes eram alguns dos principais programas transmitidos pela primeira emissora do país, a Rádio Sociedade do Rio de Janeiro, fundada em 1923.

Idealista, o professor e antropólogo Edgard Roquette-Pinto acreditava no poder de levar educação e cultura ao povo brasileiro usando a surpreendente novidade tecnológica da época: o rádio. Na década de 20 já se percebia o potencial educativo radiofônico como forma de propagar o saber graças ao seu alcance, visando a melhorar o nível de educação de uma população com elevado índice de analfabetismo.

Em 1934 foi inaugurada a estação da Rádio Escola Municipal do Distrito Federal que transmitia conhecimentos sistematizados para escolas e para o público em geral. Os alunos (radiouvintes) matriculados recebiam antecipadamente as apostilas das aulas radiofônicas pelo correio ou na própria rádio. Acompanhavam as aulas pela Rádio-Escola, resolviam as questões que estavam na apostila e as remetiam pelo correio ou as entregavam na sede da emissora. Quando tinham dúvidas sobre os exercícios se comunicavam com a Rádio-Escola por telefone, carta ou visita aos estúdios da emissora.

Em 1936, não conseguindo mais manter a Rádio Sociedade do Rio de Janeiro sem publicidade, Roquette-Pinto cedeu-a ao então Ministério de Educação e Saúde com o compromisso de que a emissora continuasse a difundir programas educativos e culturais. Ela passou, então, a denominar-se Rádio do Ministério de Educação e Cultura (Rádio MEC), iniciando-se, assim, o sistema de rádios educativas no Brasil.

Os anos 40 e 50 marcaram a chamada “época de ouro” do rádio, quando o veículo além de atingir boa parte da população era uma fonte de informação com credibilidade mesmo fora do circuito das emissoras educativas, como ocorria com o "Grande Jornal Falado Tupi” e com o “Repórter Esso”. 
Outra aproximação entre rádio e Educação ocorreu com o surgimento das emissoras universitárias, a partir de 1957, marcando o início de uma nova fase da rádio educativa no país com a implantação de emissoras dentro das universidades, local destinado à produção e a transmissão de conhecimentos científicos, tecnológicos e culturais.

Nos anos 50 e 60 foi retomado o projeto do uso educativo do rádio, sonho de RoquettePinto, nos anos 20. É desse período o projeto do MEB - Movimento de Educação de Base, que usou o rádio para alfabetizar agricultores, nas regiões Norte e Nordeste, em um projeto da CNBB - Conferência Nacional dos Bispos do Brasil, a partir da metodologia problematizadora de Paulo Freire. O Presidente Jânio Quadros prestigiou o projeto concedendo à CNBB mais de 50 concessões de emissoras de rádio AM, em todo o país. O golpe de 1964 eliminou a experiência.

Nos anos 70, o governo estimulou a faixa FM, de melhor qualidade sonora do que a AM, distribuindo novas freqüências. As primeiras emissoras FMs tocavam apenas música ambiente sem a presença de locutor. O FM se mostrou lucrativo e passou a imitar o modelo norte-americano com muitas músicas estrangeiras e poucos diálogos, conversas e comentários. Com isso, as emissoras FM passaram a dividir com as AM um bolo publicitário que já estava diminuindo. As emissoras AM ficaram com o público mais maduro e as FM com o mais jovem.

O governo militar de Castelo Branco obrigou as emissoras a dedicarem cinco horas semanais para "programas educativos”. Um dos projetos desenvolvidos na época voltou-se para o campo do ensino supletivo de primeiro e segundo graus, denominado "Projeto Minerva”. Para transmitir o programa as emissoras entravam em cadeia. Os resultados, no entanto, não justificaram a continuidade do programa nas décadas posteriores. 
A história do rádio no Brasil está diretamente relacionada a aspectos culturais, econômicos e políticos do país nos últimos 80 anos ajudando a construir a identidade nacional e prestando serviço. Trata-se de um veículo que ao longo dos últimos anos foi capaz de informar, entreter e educar sem sucumbir perante o avanço da tecnologia e o surgimento de novos meios como a TV e a Internet.

Em sua oitava década de existência, o rádio continua presente no dia-a-dia de milhões de brasileiros, nas disputas políticas em torno das concessões, nos interesses comerciais dos anunciantes e na vocação educativa e cidadã de movimentos sociais e governamentais. É ouvido pelas mais diversas faixas etárias e classes sociais. Em algumas horas da manhã, nos grandes centros urbanos, a audiência somada das emissoras de rádio chega a superar a audiência das emissoras de TV.

O rádio mudou, se transformou, evoluiu, segmentou-se, chegou ao “walkman”, ao carro, ao computador e até à escola. Neste início de século, o potencial educativo e pedagógico do rádio pôde ser resgatado por projetos que estimularam o uso da linguagem radiofônica e ganharam força entre escolas e secretarias de Educação propiciando que crianças e jovens melhorem sua capacidade expressiva, desenvolvendo a criatividade e a oralidade. Foi o caso do projeto “educom.rádio”, que, como já dissemos, capacitou todas as 455 escolas do Ensino Fundamental da cidade de São Paulo para fazer uso da linguagem radiofônica.

A teoria educomunicativa, por meio de projetos como o "educom.rádio", apresentou a perspectiva de usar o rádio como um recurso de comunicação capaz de reunir a comunidade escolar em torno do objetivo de potencializar a capacidade expressiva dos 
professores e alunos, consolidando um ecossistema comunicativo aberto e democrático na escola $^{105}$.

\section{2 - Especificidades do rádio e sua linguagem}

Considerado um dos meios de comunicação mais populares do país, o rádio resiste e se adapta às inovações tecnológicas permanecendo, ao lado da televisão, como o veículo de maior alcance e penetração nos lares brasileiros. O rádio ganhou espaço no dia-a-dia dos brasileiros devido a várias de suas principais características e especificidades:

- Utiliza a linguagem oral: mesmo analfabetos podem entender a mensagem;

- Não tem fronteiras: pode estar presente nas capitais, numa cidade longínqua do interior ou transmitir a mesma programação para um país inteiro;

- É barato: o baixo custo favorece sua aquisição pela população;

- O ouvinte de rádio não fica impedido de realizar outras tarefas: enquanto ouve rádio pode ler, dirigir, trabalhar, praticar esportes, etc;

- É um meio móvel e portátil. O ouvinte não precisa ficar em casa ao lado do aparelho, pode levá-lo para diferentes locais;

- Geralmente é o primeiro meio de massa a informar direto do local de um acontecimento. É menos complexo tecnologicamente o que facilita a substituição ou o acréscimo de novas informações durante uma transmissão;

\footnotetext{
105 - Ismar de Oliveira SOARES. “Caminhos da Educomunicação na América Latina e nos Estados Unidos”. In Caminhos da Educomunicação, 2.ed, Editora Salesiana, São Paulo, 2003
} 
- É um meio imediato e instantâneo: consegue divulgar o fato na hora do seu acontecimento. A emissão e a recepção ocorrem no mesmo momento, diferentemente dos meios impressos (como jornais e revistas);

- Transmite sons e permite que cada ouvinte crie suas imagens. O rádio trabalha o lado emocional, criando um "diálogo" com o locutor e despertando a imaginação das pessoas pelas palavras e pela sonoplastia (música e efeitos sonoros). Rudolf Arnheim, em sua obra “Estética Radiofônica”, referiu-se ao rádio como "meio cego" reconhecendo-o como um veículo capaz de criar "segundo suas próprias leis um mundo acústico da realidade”106.

Enquanto o universo pictórico é fechado, o do áudio é aberto. A existência do som, por si só, pode completar um espaço como explicam Marshall McLuhan e Edmund Carpenter:

Dizemos “a noite está cheia de música”, igual a que o ar está cheio de fragrâncias; a localização carece de significado. O público dos concertos fecha os olhos. O espaço auditivo não tem nenhum foco preferencial. É uma esfera sem fronteiras fixas, um espaço construído pela coisa em si mesma, não um espaço que contém a coisa. Não é o espaço pictórico, fechado, mas dinâmico, sempre fluente, que cria suas próprias dimensões momentos após momentos. $^{107}$

A linguagem radiofônica possibilita a realização de diferentes gêneros e formatos que vão dos ficcionais aos não-ficcionais. Como educomunicadores, e até mesmo como ouvintes, podemos encontrar em cada um deles seu potencial educativo. Marlene Blois,

\footnotetext{
106 - Rudolf ARNHEIM. A Estética Radiofônica. Barcelona, ed. Gustavo Gilli, 1980, p.88

107 - Marshall MCLUHAN \& Edmund CARPENTER apud BARBOSA FILHO, André. Gêneros radiofônicos. Tipificação dos roteiros em rádio. São Bernardo do Campo, UMESP, 1996, dissertação de mestrado, p. 70
} 
especialista na relação rádio/educação, explicita o potencial radiofônico para uma “Educação Permanente”:

Se entendermos que o Homem tem necessidade de aprender ao longo da vida - o que os educadores denominam de Educação Permanente - e que a informação está na base do conhecimento, que gera reflexão e crítica, podemos identificar traços educativos em muitos dos programas radiofônicos. O jornalismo, tanto o factual como o comentado e investigativo, abordando fatos do dia-a-dia e matérias de caráter científico, econômico, ecológico, cultural e comunitário talvez seja o que de mais marcante a programação apresente sob a ótica da Comunicação para uma Educação Permamente... A programação de música popular ou erudita, além de entreter o ouvinte leva-o a conhecer a criação artística do setor, extrapolando fronteiras nacionais ou culturais... E os programas que prestam serviço ou são considerados de utilidade pública? Além de realçar valores e atitudes 'desejáveis', criam laços de solidariedade, humanizam a cidade, destacam a consciência de que nem tudo está perdido em meio ao individualismo e a violência dos grandes centros $^{108}$.

\section{3 - A opção pelo rádio em projetos educativos e educomunicativos}

As especificidades radiofônicas vêm, nos últimos anos, dialogando cada vez mais com o horizonte cultural de crianças e jovens (imaginação, emoção, fragmentação, brevidade,

\footnotetext{
108 - Marlene BLOIS. "O rádio nosso de cada dia". In Revista Comunicação \& Educação (6), São Paulo, maio/ago 1996, p.16-17
} 
instantaneidade...). Enquanto isso, a escola, no entanto, continua sendo vista como burocratizada e com dificuldades de realizar em plenitude os processos de comunicação interna e externamente.

Desenvolver na escola ações e atividades aproveitando a riqueza dessas linguagens pode envolver e estimular crianças e jovens a aprenderem de forma lúdica, criativa e participativa, além de contribuir para a melhoria dos processos de comunicação na escola bem como para o desenvolvimento pessoal do educando. O uso planejado do rádio na escola, por meio da realização de programas radiofônicos e da implantação de uma emissora restrita (como propôs o projeto “educom.rádio”) pode trazer diversos benefícios para as diferentes instâncias envolvidas. A rádio da escola pode:

- Atuar como uma multiplicadora de informações da escola e da comunidade;

- Potencializar a divulgação dos projetos e eventos da escola;

- Discutir e pautar temas locais buscando soluções coletivas para os problemas da comunidade;

- Cobrar das autoridades as ações e os recursos que se façam necessários;

- Ampliar debates sobre mudanças de estrutura ou organização da escola;

- Facilitar a obtenção de apoios e parceiras para a realização de eventos, atividades ou melhorias na escola. Empresas da região podem fornecer materiais, alimentação ou serviços em troca da divulgação da parceria na rádio da escola;

- Estimular atividades culturais em âmbito escolar: eventos (como concursos de poesias) e obras (como peças de teatro) podem ganhar sua versão radiofônica com as devidas adaptações de linguagem;

- Fomentar as atividades inter e transdisciplinares por meio da realização dos programas radiofônicos; 
- Aprimorar a fala e os principais elementos de comunicação verbal (dicção, respiração, entonação, coerência, argumentação, etc) de alunos, professores, funcionários e membros da comunidade;

- Veicular músicas e estilos musicais que não têm espaço na grande mídia, abrir espaço aos talentos artísticos e culturais da comunidade;

- Realizar transmissões e programas esportivos sobre os jogos e competições dos quais a escola participa;

- Animar e organizar eventos e festas por meio da veiculação de músicas e de informações;

- Potencializar os resultados de campanhas ambientais e sociais promovidas pela escola;

- Propiciar que alunos e professores possam conhecer o trabalho e as idéias de docentes e estudantes que vão à escola em outros períodos.

No projeto “educom.rádio”, além de visar a contribuir para a diminuição dos índices de violência e de agressividade nas escolas públicas de São Paulo, a opção do NCE-USP pelo uso do rádio objetivou estimular os alunos a entenderem este meio de comunicação como um atrativo ponto de referência para o desenvolvimento prático de atividades comunicativas, culturais, cognitivas e cidadãs que poderiam partir tanto de iniciativas do corpo docente como dos próprios estudantes ou da comunidade. Perante os professores e funcionários, os principais desafios pedagógicos consistiam em demonstrar o potencial do rádio como facilitador da trandisciplinaridade e também como um veículo capaz de auxiliar na melhoria das relações interpessoais. 
O sucesso da capacitação do NCE-USP para a disseminação das práticas educomunicativas por meio da utilização do rádio dependia, de um lado, do compromisso do corpo docente e de sua abertura à aceitação do "novo”; e, de outro lado, da ludicidade, do prazer e do entusiasmo dos estudantes na realização dos programas radiofônicos.

O exercício da cidadania pela comunidade escolar relaciona-se com o uso democrático dos meios de comunicação social, incluindo aí o rádio, tendo em vista que no sistema de radiodifusão sonora o Brasil ainda não conseguiu viabilizar soluções eficazes para a autorização e disseminação em grande escala das emissoras comunitárias. Além disso, o país convive com um caótico e questionável processo regulatório de concessões que concentra mais emissoras nas mãos de políticos e grupos religiosos do que até mesmo de empresários do setor de comunicação. Diante desse cenário, envolto em complicados interesses financeiros, partidários e ideológicos, a viabilização de emissoras de rádio nas escolas surge com uma importante alternativa para viabilizar, de fato, o acesso de diferentes comunidades ao exercício da expressão e da comunicação, valorizando ações e temas locais. De acordo com a jornalista Adriana Azevedo,

é certamente a partir da compreensão do conceito de cidadania que se insere o debate sobre o papel da rádio nas escolas, pois, dependendo do grupo social em que está inserido e da forma como este meio de comunicação for conduzido, certamente este poderá vir a ser um elemento importante para a construção de mecanismos de libertação... Certamente, o futuro da democracia dependerá da possibilidade que tenham os cidadãos de participar ativamente e com conhecimento dos diversos processos políticos, sociais e econômicos, e o rádio, enquanto meio de difusão dessas 
falas, nas comunidades, torna-se um elemento fundamental convertendo-se em instrumento dinâmico e agente da transformação social. ${ }^{109}$

O rádio (não só o veículo de comunicação, mas a própria linguagem radiofônica) se mostra como um elemento propiciador de experiências educacionais diferenciadas, transformadoras e relevantes que podem alterar o ambiente escolar, ressignificando as relações humanas e colaborando para a construção de um eficiente ecossistema comunicativo.

A relação entre o rádio e a Educação tem ganhado novo vigor em âmbito escolar com a implementação de projetos que além de promover a escuta e análise de programas radiofônicos, estimulam a criação de emissoras de rádio dentro das escolas com transmissões em circuito fechado ou semi-aberto. A programação de cunho pedagógico e cultural é geralmente produzida conjuntamente por alunos, educadores e membros da comunidade escolar.

Na cultura da imprensa escrita, dos livros e dos textos, a disposição das informações é linear, hipotética e dedutiva. Já na linguagem radiofônica podemos trabalhar a mixagem, a intuição, a afetividade e a imaginação. A fala e as formas de agir e pensar dos jovens que já nasceram nessa cultura audiovisual estão cada vez mais afetadas pelas características dessa linguagem das mídias televisiva e radiofônica e, muitas vezes, se choca com a postura livresca e linear da escola.

É importante procurar usar adequadamente os novos recursos tecnológicos de comunicação nos processos de ensino-aprendizagem e nas atividades que ampliem as possibilidades de expressão de crianças e jovens, utilizando a mídia em uma perspectiva

\footnotetext{
109 - Adriana AZEVEDO. Escola e Comunicação: o rádio como instrumento de cidadania. Disponível em http://www.educomradio.com.br/cafe/cafe.asp?editoria=TSUPH\&cod=440. Acessado em 16/06/2004
} 
pedagógica e aproveitando o fascínio e a sedução propiciados por outras linguagens como a radiofônica, proporcionando experiências educativas diferenciadas. A prática da linguagem radiofônica tem se mostrado ainda uma excelente aliada para a discussão e promoção de temas considerados transversais nos currículos dos Ensinos Fundamental e Médio.

Cabe neste momento uma reflexão em torno das diferenças de realização de programas radiofônicos nas escolas em comparação como o uso do rádio pela mídia tradicional. Os meios de massa sofrem do processo de "obsolescência acelerada”, com uma incalculável sucessão de conteúdos em seqüência. Quase tudo o que acabou de ser veiculado já ficou velho, dafasado, desatualizado e não será mais exibido. A lógica industrial predomina: novos conteúdos, programas, quadros, matérias e reportagens são veiculados seguidamente um depois do outro.

Os profissionais dos meios de comunicação de massa dedicam pouco, e às vezes nenhum tempo, para a avaliação dos programas no que diz respeito ao conteúdo, à linguagem, ao formato e, principalmente, aos aspectos éticos e aos usos sociais de cada produção. Quando um programa termina, sua equipe já está pensando na realização do próximo. A avaliação e análise dos programas, bem como as sugestões de mudanças, ficam condicionadas quase exclusivamente às oscilações dos índices de audiência, aos interesses dos grupos que controlam as emissoras e às pressões do mercado publicitário.

Já a Educomunicação propõe não só a compreensão das etapas de realização de programas e produtos comunicativos como também agrega algumas fases e orientações em relação às etapas comumente conhecidas de realização de programas radiofônicos. Nesta relação podemos incluir a avaliação não só do produto, mas principalmente do processo; a gestão participativa e democrática; as decisões coletivas e a busca de horizontalidade nas funções desempenhadas. 
As formas de conceber e produzir produtos midiáticos no espaço escolar ou em instituições educativas não podem ser as mesmas adotadas pelos meios de comunicação de massa, pois além dos recursos tecnológicos disponíveis os objetivos também são diferenciados. Trata-se do uso da mídia numa perspectiva pedagógica visando ao desenvolvimento da capacidade expressiva infanto-juvenil e acima de tudo de exercícios de promoção da cidadania e das culturas locais.

Neste sentido, podemos resumir da seguinte forma as principais diferenças em relação às produções radiofônicas educomunicativas e aquelas realizadas pelos meios de massa:

\begin{tabular}{|c|c|}
\hline Programas educomunicativos $^{110}$ & Programas dos meios de massa \\
\hline Gestão participativa e democrática. & $\begin{array}{l}\text { Decisões tomadas por diretor, editor-chefe, } \\
\text { coordenador de produção, etc... }\end{array}$ \\
\hline Relação horizontal. & Relação vertical, níveis hierárquicos. \\
\hline $\begin{array}{l}\text { Predomínio da mediação, da } \\
\text { negociação, da gestão democrática. }\end{array}$ & $\begin{array}{l}\text { Predomínio da determinação, do cumprimento de } \\
\text { ordens. }\end{array}$ \\
\hline Voz ativa para crianças e jovens. & $\begin{array}{l}\text { Ausência de voz ativa para crianças e jovens (estes } \\
\text { apenas reproduzem as ordens vindas dos } \\
\text { “profissionais” adultos até mesmo em emissoras } \\
\text { públicas e educativas). }\end{array}$ \\
\hline $\begin{array}{l}\text { Avaliação dos produtos relacionada } \\
\text { às necessidades e demandas sociais } \\
\text { e culturais da comunidade local. }\end{array}$ & $\begin{array}{l}\text { Avaliação dos produtos relacionada a aspectos } \\
\text { mercadológicos, institucionais e comerciais. }\end{array}$ \\
\hline $\begin{array}{l}\text { Ênfase na avaliação dos processos } \\
\text { de realização. }\end{array}$ & $\begin{array}{l}\text { Quase inexistência da avaliação dos processos. } \\
\text { Avaliação de conteúdo e linguagem relacionada aos } \\
\text { índices de audiência ou ao faturamento publicitário. }\end{array}$ \\
\hline
\end{tabular}

110 - Ismar de Oliveira SOARES. “Caminhos da Educomunicação na América Latina e nos Estados Unidos”. In Caminhos da Educomunicação, 2.ed, Editora Salesiana, São Paulo, 2003

"Comunicação/Educação: a emergência de um novo campo e o perfil de seus profissionais”. In Contato - Revista Brasileira de Comunicação, Arte e Educação num. 2, Brasília: Senado Federal, jan/mar 1999, p.19-74

"Metodologias da educação para comunicação e gestão comunicativa no Brasil e na América Latina”. In Maria Aparecida BACCEGA, Gestão de processos comunicacionais, São Paulo-SP, Atlas, 2002 
Partindo do conhecimento das fases essenciais de realização radiofônica, o NCE-USP propôs, desde a primeira fase do projeto “educom.rádio”, um esquema seqüencial de atividades $^{111}$ destinado a orientar estudantes e professores a desenvolver, socializar e avaliar os programas de rádio durante os sábados de capacitação presencial.

1 - Levantamento e definição de pauta: momento em que todos podem opinar sobre os temas e assuntos do programa bem como a forma de abordagem dos mesmos. Os itens propostos são anotados na lousa ou em cartazes de modo que todos vejam os rumos tomados pelo grupo. Uma vez expostas as idéias procede-se à votação para escolha democrática exercitando de forma prática a gestão participativa;

2 - Preparação/Produção do programa: fase em que são distribuídas as funções, de acordo com as necessidades e o formato do programa. Inclui ainda os ensaios e a própria gravação do programa. Se a intenção for realizá-lo ao vivo, este é o momento em que todos se prepararam para a próxima fase de apresentação;

3 - Apresentação: fase em que os participantes tornam público o que juntos realizaram e/ou idealizaram. O grupo pode apresentar-se “ao vivo” (gravando o programa ao mesmo tempo em que se apresenta numa sala ou num pátio) ou, se já gravou o programa em uma fita ou em um CD, pode colocá-lo no aparelho de som e exibir sua produção. O critério para a ordem de apresentação (no caso de mais de uma equipe) é sempre discutido com os participantes;

\footnotetext{
111 - Entre a $1^{\text {a }}$ e a $4^{\text {a }}$ fases, falava-se em "quatro etapas" da produção de rádio. A partir da 5a. fase, adotou-se o esquema de cinco atividades seqüenciais, com o acréscimo da avaliação. É importante assinalar que as denominadas "cinco etapas" dizem respeito apenas aos procedimentos de como conduzir pedagogicamente o trabalho com os cursistas, não se constituindo, de nenhuma forma, na "metodologia" do "educom.rádio". Para o professor Ismar Soares, a Educomunicação não dispõe de uma metodologia, mas de princípios e pressupostos.
} 
4 - Aplicação: discussão sobre a utilização do programa de rádio em diferentes situações do ambiente escolar, desde momentos festivos ou de recreação como também em situações mais formais de ensino (na sala de aula, na biblioteca, no laboratório de informática, etc). É o momento em que o grupo pensa no "para quê" daquilo que se produziu. Trata-se de uma reflexão que se inicia logo na primeira etapa (definição de pauta) e que pode nortear a produção, viabilizando aplicações mais dirigidas para um processo educomunicativo;

5 - Avaliação: momento em que os participantes avaliam o processo e o produto final de seu trabalho. A avaliação pode estar incluída em todas as fases, durante a própria realização. É o “fazer pensando”. Porém, ao final da realização (e até mesmo da veiculação do programa) pode questionar o quanto se atingiu dos objetivos iniciais, do público-alvo pretendido, etc. Além de avaliar internamente processos e produtos, o grupo realizador pode ganhar dimensão externa relativa ao impacto do que foi feito incluindo aí métodos qualitativos (comentários que os programas geraram, por exemplo) e/ou quantitativos (questionários com a comunidade escolar).

Estas etapas puderam ser apresentadas, discutidas e vivenciadas nas atividades práticas realizadas durante os sábados de capacitação presencial e serviram para nortear alunos e professores visando à continuidade das práticas radiofônicas em suas escolas bem como à multiplicação para diferente agentes da comunidade escolar. Foram importantes para apresentar aos cursistas novos modelos alternativos à mídia tradicional e permitir que incorporassem conceitos relacionados à aplicação dos produtos que desenvolveram, à avaliação dos processos, à gestão participativa e à competência comunicativa. 
Obviamente também foram estudados conceitos e técnicas relacionados à linguagem, aos gêneros e formatos, à operacionalização, ao manuseio e à manutenção dos equipamentos. No entanto, como esclarece a professora da ECA-USP, Marília Franco, as atividades não privilegiavam questões técnicas e operacionais, mas sim os conteúdos e os processos comunicativos:

dentro da nossa perspectiva de inserção do Rádio em ecossistema educativo, o trabalho que desenvolvemos não é o que comumente se chama de "oficina de rádio”. Não se trata de uma abordagem instrumental de domínio de tecnologia e técnicas, mas da aquisição e do desenvolvimento de uma capacidade de comunicação que valorize cada indivíduo que a exercite e que, a partir desse exercício, se torne um meio de elevação, eficiência $e$ transformação da qualidade de vida da comunidade que se comunica ${ }^{112}$.

Diferentemente de muitos projetos que levam as "mídias” ou as “artes" para as instituições de ensino, o “educom.rádio” procurou não se limitar apenas à leitura crítica, à aplicação de cursos técnicos ou ao desenvolvimento de oficinas performáticas (em que uma equipe passa um breve período na escola levando os instrumentos e materiais necessários, desenvolve uma atividade com os estudantes ou com a comunidade; e depois vai embora levando consigo os materiais e as idéias sem deixar uma perspectiva de continuidade dessas ações na escola). Ao contrário, o projeto buscou conciliar atividades radiofônicas teóricas e práticas pautadas pela preocupação com os processos comunicativos da escola, pela abertura às ações de protagonismo infanto-juvenil e pelo planejamento de criação de uma emissora de rádio na escola visando à continuidade das práticas educomunicativas

\footnotetext{
112 - Marília FRANCO. Ouvir e falar. Disponível em www.educomradio.com.br/centro-oeste. Acessado em $14 / 06 / 2005$.
} 
radiofônicas mesmo após o período de capacitação presencial do NCE-USP. A intenção era preparar alunos, professores e funcionários para conjuntamente planejar, implementar e gerenciar, de fato, a rádio de sua escola independentemente dos equipamentos e recursos técnicos mais ou menos avançados que viriam a receber mais cedo ou mais tarde da Prefeitura de São Paulo.

Nesse sentido, Adriana Azevedo, ex-articuladora do educom.rádio, destaca a importância do rádio na escola para a participação dos estudantes nos processos de decisão: A educação formal deve possibilitar ao educando o pensar, o refletir, a tomada de decisão, a convivência com a diferença, com o novo e o rádio, nesse sentido, vem se mostrando como um instrumento capaz de desenvolver em nossas crianças e jovens tais competências habilidades... O rádio na escola, como já estamos podendo visualizar, é um instrumento muito poderoso, capaz de agregar sentido à existência de nossas vidas dentro do universo escolar. Transcender, discernir, dialogar (comunicar $e$ participar $)^{113}$.

Enfim, este breve capítulo nos mostra novos caminhos a respeito do uso lúdico e pedagógico da linguagem radiofônica resgatando alguns dos princípios que nortearam o rádio brasileiro logo na sua origem quando o então novo veículo buscava promover a educação. Oito décadas mais tarde, e depois de inúmeros avanços tecnológicos, o rádio continua sendo um dos veículos de comunicação social mais importantes do país à disposição e ao alcance de todas as camadas sociais atingindo cidadãos escolarizados ou não, de diferentes idades devido às suas especificidades e características. Neste contexto, a

\footnotetext{
113 - Adriana AZEVEDO. Alunos do educom.rádio levam mensagem de paz à UMESP. In Boletim O Educomunicador num. 02, São Paulo, 2001, p.5. Disponível em www.usp.br/educomradio/download/boletim03.pdf. Acessado em 14/10/2006.
} 
Educomunicação propõe, em pleno século XXI, a aplicabilidade do rádio como suporte pedagógico tanto na sala de aula como fora dela visando a uma educação inclusiva, participativa e cidadã deslocando o uso do rádio de uma vivência individual para uma experiência coletiva. 


\section{Capítulo 5}

\section{O “educom” no rádio: análise das produções radiofônicas dos cursistas}

\section{1 - Universo, amostragem e categorias de classificação}

O projeto "educom.rádio" capacitou alunos, professores, funcionários e membros das comunidades das escolas de Ensino Fundamental da cidade de São Paulo para práticas educomunicativas concebidas a partir do uso da linguagem radiofônica. A realização de programas de rádio foi uma constante durante os sete semestres de implementação do projeto nas escolas-pólos. Nossa pesquisa tem com um de seus objetivos, justamente, realizar um levantamento aprofundado do vasto material produzido.

Desta forma, por meio de uma análise quantitativa, pretendemos investigar quais os gêneros, formatos e temas mais presentes nas produções que resultaram dos processos de capacitação. Interessa-nos saber quais as características dos produtos, assim como formatos e gêneros que diferenciam e/ou aproximam as produções realizadas em ambiente escolar daquelas veiculadas em emissoras comerciais; identificar as diferenças entre os programas realizados apenas por alunos e os produzidos conjuntamente por estudantes, docentes e funcionários; verificar como as mudanças de coordenação e orientações do "educom.rádio" refletiram em alterações na quantidade e nas características das produções radiofônicas entre o início e o final do projeto. 
O banco de dados do acervo do setor de "Memória Audiovisual"114 do NCE-USP registra a preservação de 2.225 produções radiofônicas ${ }^{115}$ realizadas durante o processo de capacitação, ao longo dos três anos e meio do projeto. Sabemos, de antemão, que este número não corresponde à totalidade de produções, uma vez que as produções disponíveis correspondem apenas às fases $1,2,4,5$, e $7^{116}$. É preciso registrar, por outro lado, que eram inseridas no site do NCE-USP tão somente os programas que, trazidos à sede do NCE-USP pelos articuladores ou assistentes de direção de cada pólo de formação, apresentavam condições técnicas de serem digitalizados e catalogados.

Destaque-se, também, que o projeto atendia simultaneamente, em um mesmo sábado, a diferentes pólos nos quais cada equipe do NCE-USP podia propor atividades diferentes aos cursistas, levando em conta que - preservadas as orientações essenciais - tinha uma certa autonomia para adaptar o planejamento proposto pelo NCE-USP às condições de infraestrutura dos locais e às demandas e características específicas dos cursistas envolvidos.

O projeto “educom.rádio” nos oferece um rico e ao mesmo tempo complexo universo de pesquisa, tendo em vista que passou por reformulações ao longo de três anos e meio. Cada uma das sete fases semestrais registrou, pois, diferentes números de escolas atendidas e de produções radiofônicas realizadas.

Com exceção da $7^{\mathrm{a}}$ fase $\left(2^{0}\right.$ semestre de 2004), a digitalização das produções radiofônicas e a criação de um banco de dados por parte do NCE-USP não foram realizadas

114 - A criação do setor de “Memória Audiovisual” do NCE-USP foi uma iniciativa da coordenadora geral do projeto Patrícia Horta, contando com o apoio do supervisor, Ismar Soares. O grupo coordenado por Márcia Coutinho, além de digitalizar os programas radiofônicos foi, também, o responsável pela captação e edição de uma série de produções videográficas que documentaram o projeto. O setor foi composto, entre 2002 e 2004 , pelos seguintes integrantes: Diego Fernandez, Eliza Capai, Érika Milena Scarpinella, Francine Sayuri Segawa, Francisco José da Silva, Luiz Altieri Soares, Marta Bernardo César e Renato Tavares Junior.

115 - Conforme informamos anteriormente, é importante ressaltar que parte das produções radiofônicas digitalizadas pelo NCE-USP foi inserida no site do projeto (www.usp.br/educomradio) e está classificada pelos nomes das escolas a que os cursistas pertenciam. No ambiente virtual foi disponibilizado pelo menos um programa de cada unidade escolar participante do “educom.rádio”.

116 - Até o momento da conclusão da presente dissertação as produções das fases 3 e 6 ainda não haviam sido inseridas no banco de dados do setor de "Memória Audiovisual” do NCE-USP. 
nas mesmas semanas em que os programas eram gravados nas escolas. O fato levou, certamente, à perda de algum material. Nesse sentido, como já foi ressaltado, temos ciência de que não temos 100\% dos programas radiofônicos realizados nas 455 EMEFs. Sabemos, contudo, que estamos diante de um universo muito rico e heterogêneo, extremamente útil para pesquisas acadêmicas sobre a inter-relação Comunicação/Educação. Também temos ciência de que diante da quantidade de produtos midiáticos realizados e disponibilizados faz-se necessário definir uma amostragem eficaz e, para isso, precisamos primeiramente conhecer o universo de que podemos dispor.

\begin{tabular}{|c|c|c|c|}
\hline Fase & Período & $\begin{array}{c}\text { Escolas } \\
\text { atendidas }\end{array}$ & $\begin{array}{c}\text { Programas radiofônicos no } \\
\text { banco de dados do NCE/USP }\end{array}$ \\
\hline 1 & $2^{\circ}$ semestre/2001 & 27 & 80 \\
\hline 2 & $1^{\circ}$ semestre/2002 & 39 & 93 \\
\hline 3 & $2^{\circ}$ semestre/2002 & 55 & - \\
\hline 4 & $1^{\circ}$ semestre/2003 & 65 & 631 \\
\hline 5 & $2^{\circ}$ semestre/2003 & 78 & 791 \\
\hline 6 & $1^{\circ}$ semestre/2004 & 123 & - \\
\hline 7 & $2^{\circ}$ semestre/2004 & 68 & 630 \\
\hline \multicolumn{2}{|c|}{ TOTAL disponível } & $\mathbf{4 5 5}$ & $\mathbf{2 . 2 2 5}$ \\
\hline
\end{tabular}

\subsection{1 - Definindo a amostragem}

Diante de tantas produções radiofônicas foi necessário definir uma amostragem para uma análise que contemplasse um número significativo de programas e, ao mesmo tempo, permitisse uma comparação entre diferentes momentos do projeto. Definimos, então, que nossa amostragem nesta pesquisa contemplaria 134 escolas: 
- as 66 primeiras que participaram do projeto “educom.rádio” na fase $1\left(2^{\circ}\right.$ semestre/2001) e na fase 2 ( $1^{\circ}$ semestre/2002);

- $\quad$ as 68 últimas que foram atendidas na fase 7 ( $2^{\circ}$ semestre/2004).

Alguns fatores foram decisivos na definição da amostragem como:

- a constatação de que estas três fases dispunham de dados completos em relação:

a) aos realizadores dos programas (alunos, professores e membros da comunidade);

b) aos formatos dos programas;

c) aos assuntos dos programas.

- minha participação como pesquisador e membro da equipe de "Memória Audiovisual” do NCE-USP de boa parte da digitalização e montagem do banco de dados dessas três fases;

- a intenção de analisar e comparar as primeiras e as últimas produções radiofônicas do projeto, englobando um número semelhante de escolas: cerca de 70 que foram contempladas com o curso do “educom.rádio” no início do projeto e cerca de 70 que participaram do “educom.rádio” no final do projeto.

Sendo assim, a pesquisa se propõe a realizar uma análise quantitativa de $\mathbf{6 6 8}$ programas de rádio de aproximadamente 134 escolas atendidas no início e no final do projeto, distribuídos da seguinte forma:

- Fase 1: 80 programas (27 escolas);

- $\quad$ Fase 2: 93 programas (39 escolas);

- Fase 7: 495 programas (68 escolas). 
É importante destacar que dos 630 programas radiofônicos da Fase 7, contabilizamos 495 que dispõem, no banco de dados do NCE-USP, de todas as informações que consideramos relevantes para a pesquisa como "realizadores dos programas", “formato/gênero” e “assunto/temas”. Portanto, nossa pesquisa analisará a produção radiofônica:

de 29,5\% das escolas atendidas (134 de 455) pelo projeto “educom.rádio”;

de $\mathbf{3 0 \%}$ dos programas radiofônicos digitalizados e catalogados pelo NCE-USP (668 de 2.225).

Definida a amostragem, passamos, então, à criação de categorias que permitam a realização de levantamentos quantitativos levando em conta as variáveis que pretendemos analisar:

- Os realizadores dos programas;

- Os gêneros e formatos dos programas;

- Os temas e assuntos dos programas.

Quanto à divisão relativa aos autores/realizadores das produções radiofônicas deparamonos com três situações vivenciadas ao longo do projeto:

- Programas realizados só por alunos;

Programas realizados só por professores/funcionários;

Programas realizados conjuntamente por alunos e professores. 
Durante as atividades teóricas e prática do projeto “educom.rádio” entre 2001 e 2004, havia a presença de membros da comunidades (parentes de alunos, moradores da região, etc) que participavam dos encontros. No entanto, dependendo da idade, da formação escolar e, até mesmo, do interesse destas pessoas, elas mesmas podiam optar entre acompanhar as atividades com o grupo de professores e funcionários ou com o grupo de estudantes. Portanto, nas três classificações propostas para os realizadores das produções radiofônicas podemos ter a presença de membros da comunidade. Sendo assim, não foi possível criar uma nova categoria em relação à participação destas pessoas, pois não temos como comprovar em que grupos estavam e nem mesmo de quais programas participaram, pois algumas escolas não chegaram a inscrever membros da comunidade entre os cursistas do projeto.

Se foi possível criar as categorias relativas aos realizadores levando em consideração apenas o nosso conhecimento sobre a logística do projeto, o mesmo não ocorreu para a definição de categorias referentes aos gêneros/formatos e aos temas/assuntos. Foi necessária uma familiarização maior com o banco de dados para definir:

- um número mínimo e, ao mesmo tempo, eficaz de categorias que pudesse contemplar a maioria das produções radiofônicas;

- categorias que tivessem relevância (como o formato ou como o tema), ainda que não representassem uma quantidade extremamente significativa no total de programas. 


\subsection{2 - Categorias e gêneros}

A categorização dos gêneros e formatos apresenta ainda outra dificuldade: a falta de consenso em torno de uma divisão clara e universalmente aceita a respeito da classificação e denominação dos gêneros e formatos radiofônicos. Termos como "gênero radiofônico", “formato radiofônico”, “programa de rádio”, “programação radiofônica” e "produto radiofônico” são confundidos e utilizados muitas vezes como sinônimos, sem que haja concordância quanto aos seus significados. Parte dos autores entende que o gênero determina as características gerais de um programa e se subdivide em categorias: os formatos.

Na verdade, o audiovisual comporta uma série de gêneros. Não existe uma classificação rígida nem consensual para definir a que gênero pertence um produto de áudio, um vídeo, um programa de rádio ou um programa de TV. Há autores que não desvinculam os gêneros radiofônicos nem mesmo dos gêneros televisivos, como explicam María del Pilar Martínez (Universidade de Navarra, na Espanha) e Susana Herrera (Universidade de Piura, no Peru):

Existen además discrepancias en cuanto a la consideración que los autores hacen de los géneros radiofónicos. En este sentido, existen dos clases de tipologías:

1) aquellas que presentan el estudio de los géneros radiofónicos de manera autónoma e independiente (éste es el caso de las tipologías que presentan Faus, Martí o Merayo) y 
2) aquellas tipologías que abordan el estudio de los géneros audiovisuales en su conjunto y en las que los géneros radiofónicos y televisivos comparten un mismo tratamiento (Cebrián Herreros, García Jiménez, etc. $)^{117}$.

Até mesmo o ato de decidir como se define um gênero não é consenso entre realizadores e pesquisadores da área de comunicação audiovisual. Alguns alegam que o gênero é definido pela intenção do realizador como, por exemplo: com a intenção de educar, faz-se uma ficção para transmitir conteúdos educativos; isso levaria o programa a ser classificado no gênero "educativo" e não como "fiç̧ão" ou "dramaturgia”. Outros realizadores e pesquisadores defendem que são as características que definem o gênero. Então, no caso anterior, o gênero seria ficção ou dramaturgia (e não educativo), pois há uma história que foi roteirizada, personagens, ações, etc...

Um mesmo autor, como Vigil, propõe diferentes classificações dos gêneros sob três perspectivas dependendo se usará como base o receptor, a mensagem ou o emissor. Segundo o autor cubano, de acordo com o modo de produção da mensagem, há três gêneros (dramático, jornalístico e musical); segundo a intenção do emissor, existem oito gêneros (informativo, educativo, entretenimento, participativo, cultural, religioso, mobilização social e publicitário); e de acordo com a segmentação dos destinatários podemos identificar sete gêneros (infantil, juvenil, feminino, de terceira idade, sertanejo, urbano e sindical) $^{118}$.

Para o levantamento quantitativo desta pesquisa partimos do princípio de que todas as produções radiofônicas realizadas ao longo do projeto “educom.rádio” foram produzidas

117 - Susana HERRERA \& Maria del Pilar MARTÍNEZ. Qué son los géneros radiofónicos y por qué deberían importarnos. Disponível em http://gmje.mty.itesm.mx/articulos3/articulo_7.html. Acessado em 11/11/2006

118 - José Ignácio López VIGIL. Manual urgente para radialistas apaixonados. Ed. Paulinas, São Paulo, 1994 
com "intencionalidade educativa” e por isso excluímos o gênero "educativo" de nosso levantamento. Decidimos investigar quais gêneros e formatos foram os mais utilizados pela comunidade escolar (alunos, professores, funcionários) para desenvolver produtos de áudio por meio da linguagem radiofônica com a intencionalidade educativa presente tanto no processo como no produto final.

Uma definição que tem sido muito usada para diferenciar "gênero" de "formato" esclarece que o primeiro corresponde a uma classificação por “objetivo”, ou seja, o que o ouvinte espera do programa; enquanto o segundo diz respeito à forma, ao jeito, ao “como” se faz o programa.

Diante desses parâmetros e do contato com os momentos de realização de programas radiofônicos nas escolas, chegamos à seguinte proposta de categorização para nosso levantamento quantitativo, incluindo:

a) seis gêneros ${ }^{119}$ :

- Ficção/Dramaturgia (programas com ficcionalização ou dramatização de histórias reais, adaptadas ou inventadas, podendo conter personagens, conflitos, diálogos, narradores, clímax, etc);

- Jornalístico/Informativo (boletins, notas, matérias, reportagens, entrevistas, debates, comentários e opiniões);

- Variedades (predomínio da mescla de diferentes gêneros e formatos em um mesmo programa podendo conter informação, humor, música, etc);

- Humor (predomínio de situações cômicas com elementos como piadas, paródias, imitações, etc);

\footnotetext{
119 - Para exemplificar a classificação proposta, disponibilizamos no CD que acompanha a dissertação nove produções realizadas pelos cursistas do "educom.rádio": ficção (adaptação de um conto, na faixa 56 e radionovela original, na faixa 57); jornalístico (debate, na faixa 58 e notas informativas, na faixa 59); variedades (faixa 60); humor (faixa 61); musical (faixa 62); propagandístico (faixa 63) e vinheta (faixa 64).
} 
- Musical (predomínio de veiculação de músicas no programa).

- Publicitário/propagandístico (predomínio de venda de produtos e serviços ou de idéias e ideologias).

b) um formato:

- Vinheta (casos em que houve apenas realização da "assinatura sonora” de um programa ou da “emissora” da escola).

É importante ressaltar que raramente um gênero ou formato aparece em seu estado puro. Geralmente os programas mais criativos aproveitam características e recursos atribuídos a mais de um formato e até mesmo a mais de um gênero. Portanto, salientamos que nossa análise classifica os programas pelo gênero ou formato predominante tendo ciência de que ele não é necessariamente o único presente na produção radiofônica.

Para a definição das categorias temáticas, levamos em consideração os eixos transversais abordados durante as atividades do projeto (diversidade cultural, saúde, meioambiente, etc) bem como os relacionados aos objetivos do “educom.rádio” (comunicação na escola, violência, etc) e também temas de relativa importância no cotidianos dos jovens (sexualidade, esportes, cultura, etc). Desta forma, pelo critério da freqüência com que aparecem, optamos por dividir e agrupar os temas e assuntos em treze categorias da seguinte forma:

• Comunicação na escola (Educação, Educomunicação, “educom.rádio”);

- Meios de comunicação (programas e propagandas difundidos pelos meios de massa);

- Dia-a-dia do ambiente escolar (notícias, eventos, projetos e curiosidades);

- Ecologia e meio-ambiente; 
- Diversidade cultural (preconceito e racismo);

- Esportes;

- Arte e cultura;

- Violência (criminalidade e segurança);

- Política;

- Saúde;

- Amor e Sexualidade;

- Comportamento;

- Outros.

É importante destacar que cada produção radiofônica pode abordar mais de um dos temas citados acima. Nosso levantamento quantitativo considera todos os temas tratados em cada programa e não apenas o predominante. Nossa intenção é poder afirmar com segurança quantos, dos programas analisados, abordaram determinado tema.

\section{2 - Levantamento quantitativo}

Conforme foi justificado anteriormente, nossa amostragem para levantamento quantitativo baseia-se em 668 programas radiofônicos (ou 30\% do universo disponível). Os dados tabulados serão apresentados na seguinte seqüência:

- fases 1 e 2 (começo do projeto);

- $\quad \underline{\text { fase } 7}$ (final do projeto);

- e, por fim, a soma das fases 1, 2 e 7 (nossa amostra total). 


\subsection{1 - Fases 1 e 2}

\begin{tabular}{|l|c|c|}
\hline \multicolumn{1}{|c|}{ Realizadores } & \multicolumn{2}{c|}{ Total de programas } \\
\hline Alunos e Professores & 100 & $58,8 \%$ \\
\hline Alunos & 70 & $40,5 \%$ \\
\hline Professores & 3 & $1,7 \%$ \\
\hline Total & 173 & $100 \%$ \\
\hline
\end{tabular}

Fases 1 e 2, por gênero:

\begin{tabular}{|l|c|c|c|c|}
\hline \multicolumn{1}{|c|}{ Gênero } & Total & Alunos & Professores & $\begin{array}{c}\text { Alunos e } \\
\text { Professores }\end{array}$ \\
\hline $\begin{array}{l}\text { Jornalístico (notas, boletins, } \\
\text { reportagens, debates, entrevistas, } \\
\text { comentários) }\end{array}$ & 83 & 40 & 0 & 43 \\
\hline Variedades & 68 & 24 & 3 & 41 \\
\hline Ficção/Dramaturgia & 13 & 7 & 0 & 6 \\
\hline Musical & 9 & 5 & 0 & 4 \\
\hline Publicitário e propagandístico & 8 & 3 & 0 & 5 \\
\hline Humor & 8 & 1 & 1 & 6 \\
\hline Vinheta & 2 & 1 & 0 & 1 \\
\hline
\end{tabular}

\begin{tabular}{|l|c|}
\hline \multicolumn{1}{|c|}{ Gênero } & Total \\
\hline $\begin{array}{l}\text { Jornalístico (notas, boletins, reportagens, } \\
\text { debates, entrevistas, comentários) }\end{array}$ & $48 \%$ \\
\hline Variedades & $39,3 \%$ \\
\hline Ficção/Dramaturgia & $7,5 \%$ \\
\hline Musical & $5,2 \%$ \\
\hline Publicitário e propagandístico & $4,6 \%$ \\
\hline Humor & $4,6 \%$ \\
\hline Vinheta & $1,1 \%$ \\
\hline
\end{tabular}


Fases 1 e 2, por gênero - produzidos apenas por alunos:

\begin{tabular}{|l|c|}
\hline \multicolumn{1}{|c|}{ Gênero } & Total \\
\hline $\begin{array}{l}\text { Jornalístico (notas, boletins, } \\
\text { reportagens, debates, entrevistas, } \\
\text { comentários) }\end{array}$ & $57 \%$ \\
\hline Variedades & $34 \%$ \\
\hline Ficção/Dramaturgia & $10 \%$ \\
\hline Musical & $7 \%$ \\
\hline Publicitário e propagandístico & $4,3 \%$ \\
\hline Humor & $1,4 \%$ \\
\hline Vinheta & $1,4 \%$ \\
\hline
\end{tabular}

Fases 1 e 2, por gênero - produzidos por alunos e professores juntos:

\begin{tabular}{|l|c|}
\hline \multicolumn{1}{|c|}{ Gênero } & Total \\
\hline $\begin{array}{l}\text { Jornalístico (notas, boletins, } \\
\text { reportagens, debates, entrevistas, } \\
\text { comentários) }\end{array}$ & $43 \%$ \\
\hline Variedades & $41 \%$ \\
\hline Ficção/Dramaturgia & $6 \%$ \\
\hline Humor & $6 \%$ \\
\hline Publicitário e propagandístico & $5 \%$ \\
\hline Musical & $4 \%$ \\
\hline Vinheta & $1 \%$ \\
\hline
\end{tabular}

Fases 1 e 2, por temas:

\begin{tabular}{|l|c|c|c|c|}
\hline \multicolumn{1}{|c|}{ Conteúdo } & Total & Alunos & Professores & $\begin{array}{c}\text { Alunos e } \\
\text { Professores }\end{array}$ \\
\hline $\begin{array}{l}\text { Comunicação na escola, Educação, } \\
\text { Educomunicação, Educom.rádio }\end{array}$ & 50 & 18 & 2 & 30 \\
\hline $\begin{array}{l}\text { Ambiente escolar e comunidade: } \\
\text { informações, eventos, projetos e } \\
\text { curiosidades }\end{array}$ & 28 & 9 & 0 & 19 \\
\hline Violência, criminalidade, segurança & 25 & 9 & 0 & 16 \\
\hline $\begin{array}{l}\text { Diversidade cultural, preconceito, } \\
\text { racismo }\end{array}$ & 19 & 13 & 0 & 6 \\
\hline Política & 19 & 6 & 0 & 13 \\
\hline Ecologia e meio-ambiente & 17 & 10 & 1 & 6 \\
\hline Saúde & 14 & 7 & 0 & 7 \\
\hline Arte e cultura & 11 & 3 & 1 & 7 \\
\hline Comportamento & 7 & 4 & 0 & 3 \\
\hline Esportes & 7 & 1 & 0 & 6 \\
\hline $\begin{array}{l}\text { Meios de comunicação, programas e } \\
\text { propagandas difundidos por meios } \\
\text { de massa }\end{array}$ & 4 & 3 & 0 & 1 \\
\hline Amor, sexualidade & & & & 3 \\
\hline Outros & 3 & 0 & 0 & 3 \\
\hline
\end{tabular}




\begin{tabular}{|l|c|}
\hline \multicolumn{1}{|c|}{ Conteúdo } & Total \\
\hline $\begin{array}{l}\text { Comunicação na escola, Educação, } \\
\text { Educomunicação, Educom.rádio }\end{array}$ & $28,9 \%$ \\
\hline $\begin{array}{l}\text { Ambiente escolar e comunidade: informações, } \\
\text { eventos, projetos e curiosidades }\end{array}$ & $16,2 \%$ \\
\hline Violência, criminalidade, segurança & $14,4 \%$ \\
\hline Diversidade cultural, preconceito, racismo & $11 \%$ \\
\hline Política & $11 \%$ \\
\hline Ecologia e meio-ambiente & $9,8 \%$ \\
\hline Saúde & $8,1 \%$ \\
\hline Arte e cultura & $6,3 \%$ \\
\hline Comportamento & $4 \%$ \\
\hline Esportes & $4 \%$ \\
\hline $\begin{array}{l}\text { Meios de comunicação, programas e } \\
\text { propagandas difundidos por meios de massa }\end{array}$ & $2,3 \%$ \\
\hline Amor, sexualidade & $1,7 \%$ \\
\hline Outros & $1,7 \%$ \\
\hline
\end{tabular}

Fases 1 e 2 por temas - produzidos apenas por alunos:

\begin{tabular}{|l|c|}
\hline \multicolumn{1}{|c|}{ Conteúdo } & Total \\
\hline $\begin{array}{l}\text { Comunicação na escola, } \\
\text { Educação, Educomunicação, } \\
\text { Educom.rádio }\end{array}$ & $25,7 \%$ \\
\hline $\begin{array}{l}\text { Diversidade cultural, } \\
\text { preconceito, racismo }\end{array}$ & $18,5 \%$ \\
\hline Ecologia e meio-ambiente & $14,2 \%$ \\
\hline $\begin{array}{l}\text { Ambiente escolar e } \\
\text { comunidade: informações, } \\
\text { eventos, projetos e } \\
\text { curiosidades }\end{array}$ & $12,8 \%$ \\
\hline $\begin{array}{l}\text { Violência, criminalidade, } \\
\text { segurança }\end{array}$ & $12,8 \%$ \\
\hline Saúde & $10 \%$ \\
\hline Política & $8,5 \%$ \\
\hline Comportamento & $5,7 \%$ \\
\hline Arte e cultura & $4,2 \%$ \\
\hline $\begin{array}{l}\text { Meios de comunicação, } \\
\text { programas e propagandas } \\
\text { difundidos por meios de massa }\end{array}$ & $4,2 \%$ \\
\hline Esportes & $1,4 \%$ \\
\hline Amor, sexualidade & $0 \%$ \\
\hline Outros & $0 \%$ \\
\hline
\end{tabular}

Fases 1 e 2, por temas - produzidos por alunos e professores juntos:

\begin{tabular}{|l|c|}
\hline \multicolumn{1}{|c|}{ Conteúdo } & Total \\
\hline $\begin{array}{l}\text { Comunicação na escola, } \\
\text { Educação, Educomunicação, } \\
\text { Educom.rádio }\end{array}$ & $30 \%$ \\
\hline $\begin{array}{l}\text { Ambiente escolar e } \\
\text { comunidade: informações, } \\
\text { eventos, projetos e } \\
\text { curiosidades. }\end{array}$ & $19 \%$ \\
\hline $\begin{array}{l}\text { Violência, criminalidade, } \\
\text { segurança }\end{array}$ & $16 \%$ \\
\hline Política & $13 \%$ \\
\hline Arte e cultura & $7 \%$ \\
\hline Saúde & $7 \%$ \\
\hline $\begin{array}{l}\text { Diversidade cultural, } \\
\text { preconceito, racismo }\end{array}$ & $6 \%$ \\
\hline Ecologia e meio-ambiente & $6 \%$ \\
\hline Esportes & $3 \%$ \\
\hline Amor, sexualidade & $1 \%$ \\
\hline Comportamento & $3 \%$ \\
\hline $\begin{array}{l}\text { Meios de comunicação, } \\
\text { programas e propagandas } \\
\text { difundidos por meios de massa }\end{array}$ \\
\hline Outros
\end{tabular}




\subsection{2 - Fase 7}

\begin{tabular}{|l|c|c|}
\hline \multicolumn{1}{|c|}{ Realizadores } & \multicolumn{2}{c|}{ Total de programas } \\
\hline Alunos e Professores & 253 & $51,1 \%$ \\
\hline Alunos & 233 & $47,1 \%$ \\
\hline Professores & 9 & $1,8 \%$ \\
\hline Total & 495 & $100 \%$ \\
\hline
\end{tabular}

\section{Fase 7, por gênero:}

\begin{tabular}{|l|c|c|c|c|}
\hline \multicolumn{1}{|c|}{ Gênero } & Total & Alunos & Professores & $\begin{array}{c}\text { Alunos e } \\
\text { Professores }\end{array}$ \\
\hline $\begin{array}{l}\text { Jornalístico (notas, boletins, } \\
\text { reportagens, debates, entrevistas, } \\
\text { comentários) }\end{array}$ & 197 & 89 & 1 & 107 \\
\hline Variedades & 119 & 47 & 7 & 65 \\
\hline Ficção/Dramaturgia & 112 & 61 & 1 & 50 \\
\hline Vinheta & 25 & 19 & 0 & 6 \\
\hline Publicitário e propagandístico & 23 & 10 & 0 & 13 \\
\hline Humor & 14 & 4 & 0 & 10 \\
\hline Musical & 5 & 3 & 0 & 2 \\
\hline
\end{tabular}

\begin{tabular}{|l|c|}
\hline \multicolumn{1}{|c|}{ Gênero } & Total \\
\hline $\begin{array}{l}\text { Jornalístico (notas, boletins, reportagens, } \\
\text { debates, entrevistas, comentários) }\end{array}$ & $39,8 \%$ \\
\hline Variedades & $24 \%$ \\
\hline Ficção/Dramaturgia & $22,6 \%$ \\
\hline Vinheta & $5 \%$ \\
\hline Publicitário e propagandístico & $4,6 \%$ \\
\hline Humor & $2,8 \%$ \\
\hline Musical & $1 \%$ \\
\hline
\end{tabular}


Fase 7, por gênero - produzidos apenas por alunos:

\begin{tabular}{|l|c|}
\hline \multicolumn{1}{|c|}{ Gênero } & Total \\
\hline $\begin{array}{l}\text { Jornalístico (notas, boletins, } \\
\text { reportagens, debates, } \\
\text { entrevistas, comentários) }\end{array}$ & $38,2 \%$ \\
\hline Ficção/Dramaturgia & $26,1 \%$ \\
\hline Variedades & $20,2 \%$ \\
\hline Vinheta & $8,2 \%$ \\
\hline Publicitário e propagandístico & $4,3 \%$ \\
\hline Humor & $1,7 \%$ \\
\hline Musical & $1,3 \%$ \\
\hline
\end{tabular}

Fase 7, por gênero - produzidos por alunos e professores juntos:

\begin{tabular}{|l|c|}
\hline \multicolumn{1}{|c|}{ Gênero } & Total \\
\hline $\begin{array}{l}\text { Jornalístico (notas, boletins, } \\
\text { reportagens, debates, } \\
\text { entrevistas, comentários) }\end{array}$ & $42,3 \%$ \\
\hline Variedades & $25,7 \%$ \\
\hline Ficção/Dramaturgia & $19,8 \%$ \\
\hline Publicitário e propagandístico & $5,1 \%$ \\
\hline Humor & $4 \%$ \\
\hline Vinheta & $2,4 \%$ \\
\hline Musical & $0,8 \%$ \\
\hline
\end{tabular}

\section{Fases 7, por temas:}

\begin{tabular}{|l|c|c|c|c|}
\hline \multicolumn{1}{|c|}{ Conteúdo } & Total & Alunos & Professores & $\begin{array}{c}\text { Alunos e } \\
\text { Professores }\end{array}$ \\
\hline $\begin{array}{l}\text { Comunicação na escola, Educação, } \\
\text { Educomunicação, Educom.rádio }\end{array}$ & 121 & 54 & 6 & 61 \\
\hline $\begin{array}{l}\text { Ambiente escolar e comunidade: } \\
\text { informações, eventos, projetos e } \\
\text { curiosidades }\end{array}$ & 107 & 45 & 1 & 61 \\
\hline Violência, criminalidade, segurança & 38 & 14 & 0 & 24 \\
\hline $\begin{array}{l}\text { Meios de comunicação, programas e } \\
\text { propagandas difundidos por meios de } \\
\text { massa }\end{array}$ & 31 & 7 & 0 & 24 \\
\hline Arte e cultura & 29 & 17 & 1 & 11 \\
\hline Política & 28 & 11 & 1 & 16 \\
\hline Ecologia e meio-ambiente & 26 & 8 & 1 & 17 \\
\hline Comportamento & 24 & 13 & 0 & 11 \\
\hline Esportes & 21 & 12 & 0 & 9 \\
\hline $\begin{array}{l}\text { Diversidade cultural, preconceito, } \\
\text { racismo }\end{array}$ & 18 & 7 & 0 & 11 \\
\hline Saúde & 11 & 7 & 0 & 4 \\
\hline Amor, sexualidade & 8 & 4 & 0 & 4 \\
\hline Outros & 100 & 72 & 0 & 28 \\
\hline
\end{tabular}




\begin{tabular}{|l|c|}
\hline \multicolumn{1}{|c|}{ Conteúdo } & Total \\
\hline $\begin{array}{l}\text { Comunicação na escola, Educação, } \\
\text { Educomunicação, Educom.rádio }\end{array}$ & $24,4 \%$ \\
\hline $\begin{array}{l}\text { Ambiente escolar e comunidade: informações, } \\
\text { eventos, projetos e curiosidades. }\end{array}$ & $21,6 \%$ \\
\hline Violência, criminalidade, segurança & $7,7 \%$ \\
\hline $\begin{array}{l}\text { Meios de comunicação, programas e } \\
\text { propagandas difundidos por meios de massa }\end{array}$ & $6,3 \%$ \\
\hline Arte e cultura & $5,9 \%$ \\
\hline Política & $5,7 \%$ \\
\hline Ecologia e meio-ambiente & $5,3 \%$ \\
\hline Comportamento & $4,8 \%$ \\
\hline Esportes & $4,2 \%$ \\
\hline Diversidade cultural, preconceito, racismo & $3,6 \%$ \\
\hline Saúde & $2,2 \%$ \\
\hline Amor, sexualidade & $1,6 \%$ \\
\hline Outros & $20,2 \%$ \\
\hline
\end{tabular}

Fases 7, por temas - produzidos apenas por alunos:

\begin{tabular}{|l|c|}
\hline \multicolumn{1}{|c|}{ Conteúdo } & Total \\
\hline $\begin{array}{l}\text { Comunicação na escola, } \\
\text { Educação, Educomunicação, } \\
\text { Educom.rádio }\end{array}$ & $23,2 \%$ \\
\hline $\begin{array}{l}\text { Ambiente escolar e } \\
\text { comunidade: informações, } \\
\text { eventos, projetos e } \\
\text { curiosidades }\end{array}$ & $19,3 \%$ \\
\hline Arte e cultura & $7,3 \%$ \\
\hline $\begin{array}{l}\text { Violência, criminalidade, } \\
\text { segurança }\end{array}$ & $6 \%$ \\
\hline Comportamento & $5,6 \%$ \\
\hline Esportes & $5,2 \%$ \\
\hline Política & $4,7 \%$ \\
\hline Ecologia e meio-ambiente & $3,4 \%$ \\
\hline $\begin{array}{l}\text { Diversidade cultural, } \\
\text { preconceito, racismo }\end{array}$ & $3 \%$ \\
\hline $\begin{array}{l}\text { Meios de comunicação, } \\
\text { programas e propagandas } \\
\text { difundidos por meios de massa }\end{array}$ & $3 \%$ \\
\hline Saúde & $3 \%$ \\
\hline Amor, sexualidade & $1,7 \%$ \\
\hline Outros & $30,9 \%$ \\
\hline
\end{tabular}

Fases 7. por temas - produzidos por alunos e professores juntos:

\begin{tabular}{|l|c|}
\hline \multicolumn{1}{|c|}{ Conteúdo } & Total \\
\hline $\begin{array}{l}\text { Ambiente escolar e } \\
\text { comunidade: informações, } \\
\text { eventos, projetos e } \\
\text { curiosidades. }\end{array}$ & $24,1 \%$ \\
\hline $\begin{array}{l}\text { Comunicação na escola, } \\
\text { Educação, Educomunicação, } \\
\text { Educom.rádio }\end{array}$ & $24,1 \%$ \\
\hline $\begin{array}{l}\text { Meios de comunicação, } \\
\text { programas e propagandas } \\
\text { difundidos por meios de massa }\end{array}$ & $9,5 \%$ \\
\hline $\begin{array}{l}\text { Violência, criminalidade, } \\
\text { segurança }\end{array}$ & $9,5 \%$ \\
\hline Ecologia e meio-ambiente & $6,7 \%$ \\
\hline Política & $6,3 \%$ \\
\hline Arte e cultura & $4,3 \%$ \\
\hline Comportamento & $4,3 \%$ \\
\hline $\begin{array}{l}\text { Diversidade cultural, } \\
\text { preconceito, racismo }\end{array}$ & $4,3 \%$ \\
\hline Esportes & $3,6 \%$ \\
\hline Amor, sexualidade & $1,6 \%$ \\
\hline Saúde & $1,6 \%$ \\
\hline Outros & $11 \%$ \\
\hline
\end{tabular}




\subsection{3 - Amostragem total: Fases 1, 2 e 7}

\begin{tabular}{|l|c|c|}
\hline \multicolumn{1}{|c|}{ Realizadores } & \multicolumn{2}{c|}{ Total de programas } \\
\hline Alunos e Professores & 353 & $52,8 \%$ \\
\hline Alunos & 303 & $45,3 \%$ \\
\hline Professores & 12 & $1,8 \%$ \\
\hline Total & 668 & $100 \%$ \\
\hline
\end{tabular}

Fases 1, 2 e 7, por gênero:

\begin{tabular}{|l|c|c|c|c|}
\hline \multicolumn{1}{|c|}{ Gênero } & Total & Alunos & Professores & $\begin{array}{c}\text { Alunos e } \\
\text { Professores }\end{array}$ \\
\hline $\begin{array}{l}\text { Jornalístico (notas, boletins, } \\
\text { reportagens, debates, entrevistas, } \\
\text { comentários) }\end{array}$ & 280 & 129 & 1 & 150 \\
\hline Variedades & 187 & 71 & 10 & 106 \\
\hline Ficção/Dramaturgia & 125 & 68 & 1 & 56 \\
\hline Publicitário e propagandístico & 31 & 13 & 0 & 18 \\
\hline Vinheta & 27 & 20 & 0 & 7 \\
\hline Humor & 22 & 5 & 1 & 16 \\
\hline Musical & 14 & 8 & 0 & 6 \\
\hline
\end{tabular}

\begin{tabular}{|l|c|}
\hline \multicolumn{1}{|c|}{ Gênero } & Total \\
\hline $\begin{array}{l}\text { Jornalístico (notas, boletins, reportagens, } \\
\text { debates, entrevistas, comentários) }\end{array}$ & $41,9 \%$ \\
\hline Variedades & $28 \%$ \\
\hline Ficção/Dramaturgia & $18,7 \%$ \\
\hline Publicitário e propagandístico & $4,6 \%$ \\
\hline Vinheta & $4 \%$ \\
\hline Humor & $3,3 \%$ \\
\hline Musical & $2,1 \%$ \\
\hline
\end{tabular}


Fases 1, 2 e 7, por gênero produzidos apenas por alunos:

\begin{tabular}{|l|c|}
\hline \multicolumn{1}{|c|}{ Gênero } & Total \\
\hline $\begin{array}{l}\text { Jornalístico (notas, boletins, } \\
\text { reportagens, debates, } \\
\text { entrevistas, comentários) }\end{array}$ & $42,6 \%$ \\
\hline Variedades & $23,4 \%$ \\
\hline Ficção/Dramaturgia & $22,4 \%$ \\
\hline Vinheta & $6,6 \%$ \\
\hline Publicitário e propagandístico & $4,3 \%$ \\
\hline Musical & $2,6 \%$ \\
\hline Humor & $1,7 \%$ \\
\hline
\end{tabular}

Fases 1, 2 e 7, por gênero produzidos por alunos e professores:

\begin{tabular}{|l|c|}
\hline \multicolumn{1}{|c|}{ Gênero } & Total \\
\hline $\begin{array}{l}\text { Jornalístico (notas, boletins, } \\
\text { reportagens, debates, } \\
\text { entrevistas, comentários) }\end{array}$ & $42,5 \%$ \\
\hline Variedades & $30 \%$ \\
\hline Fição/Dramaturgia & $15,7 \%$ \\
\hline Publicitário e propagandístico & $5,1 \%$ \\
\hline Humor & $4,5 \%$ \\
\hline Vinheta & $2 \%$ \\
\hline Musical & $1,7 \%$ \\
\hline
\end{tabular}

Fases 1, 2 e 7, por temas:

\begin{tabular}{|l|c|c|c|c|}
\hline \multicolumn{1}{|c|}{ Conteúdo } & Total & Alunos & Professores & $\begin{array}{c}\text { Alunos e } \\
\text { Professores }\end{array}$ \\
\hline $\begin{array}{l}\text { Comunicação na escola, } \\
\text { Educação, Educomunicação, } \\
\text { Educom.rádio }\end{array}$ & 171 & 72 & 8 & 91 \\
\hline $\begin{array}{l}\text { Ambiente escolar e comunidade: } \\
\text { informações, eventos, projetos e } \\
\text { curiosidades }\end{array}$ & 135 & 54 & 1 & 80 \\
\hline $\begin{array}{l}\text { Violência, criminalidade, } \\
\text { segurança }\end{array}$ & 63 & 23 & 0 & 40 \\
\hline Política & 47 & 17 & 1 & 29 \\
\hline Ecologia e meio-ambiente & 43 & 18 & 2 & 23 \\
\hline Arte e cultura & 40 & 20 & 2 & 18 \\
\hline $\begin{array}{l}\text { Diversidade cultural, preconceito, } \\
\text { racismo }\end{array}$ & 37 & 20 & 0 & 17 \\
\hline $\begin{array}{l}\text { Meios de comunicação, } \\
\text { programas e propagandas } \\
\text { difundidos por meios de massa }\end{array}$ & 35 & 10 & 0 & 25 \\
\hline Comportamento & 31 & 17 & 0 & 14 \\
\hline Esportes & 28 & 13 & 0 & 15 \\
\hline Saúde & 25 & 14 & 0 & 11 \\
\hline Amor, sexualidade & 11 & 4 & 0 & 7 \\
\hline Outros & 103 & 72 & 0 & 31 \\
\hline
\end{tabular}




\begin{tabular}{|l|c|}
\hline \multicolumn{1}{|c|}{ Conteúdo } & Total \\
\hline $\begin{array}{l}\text { Comunicação na escola, Educação, } \\
\text { Educomunicação, Educom.rádio }\end{array}$ & $25,6 \%$ \\
\hline $\begin{array}{l}\text { Ambiente escolar e comunidade: } \\
\text { informações, eventos, projetos e curiosidades }\end{array}$ & $20,2 \%$ \\
\hline Violência, criminalidade, segurança & $9,4 \%$ \\
\hline Política & $7 \%$ \\
\hline Ecologia e meio-ambiente & $6,4 \%$ \\
\hline Arte e cultura & $6 \%$ \\
\hline Diversidade cultural, preconceito, racismo & $5,5 \%$ \\
\hline $\begin{array}{l}\text { Meios de comunicação, programas e } \\
\text { propagandas difundidos por meios de massa }\end{array}$ & $5,2 \%$ \\
\hline Comportamento & $4,6 \%$ \\
\hline Esportes & $4,2 \%$ \\
\hline Saúde & $3,7 \%$ \\
\hline Amor, sexualidade & $1,6 \%$ \\
\hline Outros & $15,4 \%$ \\
\hline
\end{tabular}

Fases 1, 2 e 7, por temas produzidos apenas por alunos:

\begin{tabular}{|l|c|}
\hline \multicolumn{1}{|c|}{ Conteúdo } & Total \\
\hline $\begin{array}{l}\text { Comunicação na escola, } \\
\text { Educação, Educomunicação, } \\
\text { Educom.rádio }\end{array}$ & $23,8 \%$ \\
\hline $\begin{array}{l}\text { Ambiente escolar e } \\
\text { comunidade: informações, } \\
\text { eventos, projetos e } \\
\text { curiosidades }\end{array}$ & $17,8 \%$ \\
\hline $\begin{array}{l}\text { Violência, criminalidade, } \\
\text { segurança }\end{array}$ & $7,6 \%$ \\
\hline Arte e cultura & $6,6 \%$ \\
\hline $\begin{array}{l}\text { Diversidade cultural, } \\
\text { preconceito, racismo }\end{array}$ & $6,6 \%$ \\
\hline Ecologia e meio-ambiente & $5,9 \%$ \\
\hline Comportamento & $5,6 \%$ \\
\hline Política & $5,6 \%$ \\
\hline Saúde & $4,6 \%$ \\
\hline Esportes & $4,3 \%$ \\
\hline $\begin{array}{l}\text { Meios de comunicação, } \\
\text { programas e propagandas } \\
\text { difundidos por meios de massa }\end{array}$ & $3,3 \%$ \\
\hline Amor, sexualidade & $1,3 \%$ \\
\hline Outros & $23,8 \%$ \\
\hline
\end{tabular}

Fases 1, 2 e 7, por temas produzidos por alunos e professores:

\begin{tabular}{|l|l|}
\hline \multicolumn{1}{|c|}{ Conteúdo } & Total \\
\hline $\begin{array}{l}\text { Comunicação na escola, } \\
\text { Educação, Educomunicação, } \\
\text { Educom.rádio }\end{array}$ & $25,8 \%$ \\
\hline $\begin{array}{l}\text { Ambiente escolar e } \\
\text { comunidade: informações, } \\
\text { eventos, projetos e } \\
\text { curiosidades }\end{array}$ & $22,7 \%$ \\
\hline $\begin{array}{l}\text { Violência, criminalidade, } \\
\text { segurança }\end{array}$ & $11,3 \%$ \\
\hline Política & $8,2 \%$ \\
\hline $\begin{array}{l}\text { Meios de comunicação, } \\
\text { programas e propagandas } \\
\text { difundidos por meios de massa }\end{array}$ & $7,1 \%$ \\
\hline Ecologia e meio-ambiente & $6,5 \%$ \\
\hline Arte e cultura & $5,1 \%$ \\
\hline $\begin{array}{l}\text { Diversidade cultural, } \\
\text { preconceito, racismo }\end{array}$ & $4,8 \%$ \\
\hline Esportes & $4,2 \%$ \\
\hline Comportamento & $4 \%$ \\
\hline Saúde & $3,1 \%$ \\
\hline Amor, sexualidade & $2 \%$ \\
\hline Outros & $8,8 \%$ \\
\hline
\end{tabular}




\section{3 - Análise quantitativa das produções radiofônicas}

\subsection{1 - Evolução do projeto}

Realizando uma análise comparativa entre o início (fases 1 e 2) e o final (fase 7) do projeto “educom.rádio”, a primeira grande diferença que podemos notar refere-se à quantidade de produções radiofônicas catalogadas e digitalizadas. $\mathrm{O}$ aumento no número de programas aparece como conseqüência das mudanças de orientações na coordenação pedagógica do projeto no NCE-USP, ocorrida entre a 4a e a 5a fases, que definiu dar maior importância à realização de atividades práticas ${ }^{120}$. A decisão de mudar foi tomada após a constatação, mediante avaliações dos cursistas (até mesmo dos adultos), de que havia uma desproporção, na distribuição das atividades, entre as cargas teórica e prática. Diagnosticou-se, então, a necessidade de se estimular ainda mais a realização de programas de rádio. Na $1^{\text {a }}$ fase do projeto “educom.rádio”, os cursistas realizavam programas radiofônicos, em média, em apenas três dos 12 sábados de formação. Já nas fases finais do projeto, havia a realização de produções radiofônicas em praticamente todos os encontros. Alguns cursistas chegavam a produzir dois programas no mesmo sábado. Com a realização de um número maior de produções ao longo da formação, foi possível identificar mais facilmente o aprimoramento da qualidade criativa das produções, a otimização do tempo de realização e a melhor compreensão das etapas e processos de realização.

\footnotetext{
120 - Uma das mudanças introduzidas na parte pedagógica do projeto na passagem da 4a para a 5a fase foi a criação de uma equipe de formação técnica, sob a coordenação do professor Eduardo Vicente. Além de ocupar-se com a formação técnica dos mediadores, a equipe dava atendimento às escolas que recebiam os equipamentos, oferecendo uma oficina de seis horas na unidade escolar, garantido, desta forma, que os cursistas passassem a operar adequadamente o kit de produção radiofônica.
} 
Por ironia, os cursistas das fases finais (6 e 7), mais preparados para desenvolver programas radiofônicos, foram justamente os que não puderam exercitar sua criatividade de forma plena, posteriormente, porque as escolas destas duas fases não receberam os equipamentos necessários para a implementação da rádio (por problemas nas licitações, segundo a administração municipal que governou entre 2001 e 2004, ou por decisão política, como afirmou a administração que se iniciou em janeiro de 2005, na capital paulista). Vale relembrar que cerca de 200 das 455 escolas não receberam o Kit de rádio até a entrega desta dissertação. Constatou-se, contudo, que parte das escolas prejudicadas acabaram encontrando meios de adquirir seus próprios equipamentos, sendo que a atual gestão municipal tem incentivado o uso da produção digital, valorizando a integração de mídias nas unidades escolares.

De qualquer forma, o aumento das produções radiofônicas ao longo do projeto refletiu-se tanto nas atividades apenas com os alunos, como nas práticas envolvendo conjuntamente estudantes e professores. No entanto, constatamos que a quantidade de programas de rádio realizados apenas por professores e funcionários foi muito pequena (apenas 12 das 668 produções analisadas). Como esta quantidade é praticamente insignificante (menos de 2\%), não podemos fazer uma análise comparativa envolvendo os programas realizados apenas por professores e funcionários. O número reduzido dessas produções reflete uma preocupação da coordenação pedagógica do NCE-USP de propor que os alunos realizassem mais atividades práticas relacionadas ao universo radiofônico de modo a estarem, assim, mais confiantes e preparados nos momentos de realização de programas em conjunto com os professores e funcionários. Tratava-se, na verdade, de uma estratégia para estimular uma relação mais horizontal na comunicação entre os alunos e seus professores, coordenadores 
e diretores de modo que todos pudessem igualmente vivenciar a possibilidade de ensinar, contextualizar, explicar e argumentar.

Diante do escasso número de programas realizados apenas pelos docentes optamos por comparar os programas realizados exclusivamente pelos estudantes com aqueles realizados conjuntamente por professores e alunos (ou seja, analisaremos "o que” e "como" os estudantes fizeram sozinhos e "o que” e “como" os alunos fizeram com a presença e participação dos professores).

Antes de qualquer análise comparativa, um aspecto extremamente positivo a ser destacado refere-se ao fato de que mais da metade dos programas $(52,3 \%)$ foi realizada conjuntamente por professores e estudantes, o que já representa uma quebra de paradigmas com a tradição verticalista da escola. Somando este índice aos 45,3\% das produções realizadas apenas pelos alunos, podemos comprovar que estes realmente conseguiram se envolver com quase todos os programas radiofônicos (98,1\% do total), o que, sem dúvida, os gabarita a conduzir processos de multiplicação das técnicas e linguagens aprendidas para outros estudantes e professores de sua unidade escolar que não participaram do projeto. ${ }^{121}$

Prosseguindo na análise comparativa entre o início (fases 1 e 2) e o final (fase 7) do projeto educom.rádio, podemos constatar - por meio do levantamento quantitativo das produções radiofônicas - que em ambas as fases houve predomínio do gênero jornalístico. Porém, ao longo do andamento do projeto diagnosticamos maior variedade na distribuição dos gêneros dos programas tanto que o predomínio jornalístico caiu de 48\% para 39,8\%. Entre os gêneros que passaram a ser mais contemplados com as mudanças de fases,

\footnotetext{
121 - É importante destacar que os alunos cursistas do "educom.rádio" deixavam a escola ao concluir a 8a série do Ensino Fundamental. O fato acabou levando alguns diretores e coordenadores, indispostos com o projeto, a trancar os equipamentos em depósitos até a saída total dos estudantes formados no projeto. Dessa forma, inviabilizaram o volume de recursos e de esforços dedicados ao projeto pudessem viabilizar, de fato, uma alternativa pedagógica para as escolas municipais de São Paulo.
} 
destaca-se o ficcional, que registrou crescimento significativo saltando de 7,5\% para 22,6\%. Portanto, podemos afirmar que a intensificação da prática radiofônica triplicou a escolha pelo gênero ficcional tanto nos programas realizados apenas por alunos (passando de $10 \%$ para $26,1 \%$ ) como naqueles produzidos conjuntamente por estudantes e professores (subindo de 6\% para 19,8\%).

Assim como foi possível constatar maior variedade de gêneros e formatos ao longo do projeto, também percebemos uma melhor distribuição dos temas, tendo em vista que o predominante “Comunicação na escola (Educação, Educomunicação, “educom.rádio)” caiu de $28,9 \%$ para $24,4 \%$ enquanto os assuntos relacionados a "Ambiente escolar $e$ comunidade” estiverem presentes em maior número de programas subindo de 16,2\% para 21,6\%. O aumento da prática radiofônica abriu espaço para outros temas que não dissessem respeito apenas ao próprio curso e possibilitou a opção por mais pautas locais relacionadas à comunidade escolar. Ambos os temas predominantes dizem respeito à escola e, desta forma, podemos constatar que nortearam a produção dos cursistas, indicando que alunos e professores mantiveram atenção especial na discussão sobre o ecossistema comunicativo escolar: 45,1\% dos programas das fases 1 e $2(28,9 \%+16,2 \%)$ e $46 \%$ das produções da fase $7(24,4 \%+21,6 \%)$.

O crescimento das atividades práticas durante os encontros e a realização de mais programas radiofônicos levou inclusive a uma dificuldade de categorização de modo que 20,2\% das produções abordaram temas que não puderam ser classificados em nenhuma das categorias temáticas estabelecidas. Isto se explica pelas experimentações de linguagem propostas aos cursistas pelas equipes do NCE-USP como:

- programas com temas abstratos; 
- exercícios como a realização de programas apenas com ruídos e efeitos sonoros, sem uso de palavras.

Ficou comprovado que a perspectiva de realizar mais produções radiofônicas levou os cursistas a terem mais liberdade na escolha dos temas saindo das pautas que pareciam mais óbvias por estarem diretamente atreladas aos objetivos do projeto (Educomunicação, escola, violência).

Foi possível constatar ainda que a variação dos gêneros entre as primeiras e a última fases correspondeu também a uma maior variedade temática. Apesar da melhor distribuição de temas, identificamos que três assuntos predominaram, na mesma ordem, tanto no início como no final do projeto:

• $1^{\circ}$ ) Educomunicação (Comunicação na escola, Educação, “educom.rádio”);

- $2^{\circ}$ ) Escola (ambiente escolar e comunidade: informações, eventos, projetos, curiosidades);

- $\quad 3^{\circ}$ ) Violência (criminalidade, segurança).

Analisando a distribuição dos gêneros e formatos radiofônicos, na totalidade de nossa amostragem, é interessante notar que o predomínio do jornalístico ocorreu de forma simultânea e semelhante tanto nas produções realizadas apenas pelos estudantes $(42,6 \%)$ como naquelas com participação dos professores (42,5\%), diferentemente do que poderíamos esperar se partíssemos da idéia de que os adultos preferem e estão muito mais familiarizados com o jornalismo do que as crianças e os adolescentes (que tendem a preferir, na condição de ouvintes, os programas musicais e de entretenimento). 
A participação de crianças e adolescentes no projeto revelou uma mudança de postura dos jovens em relação ao gênero jornalístico: apesar de não gostarem de ouvir ou analisar programas do gênero, eles demonstraram interesse e empenho em realizar programas deste tipo a partir do momento em que assumem função ativa, tendo vez e voz para selecionar e transmitir informações, além de emitir opiniões quando se vêem atuando como redatores e principalmente repórteres, entrevistadores e comentaristas.

O predomínio do gênero jornalístico pode ser explicado, em parte, por fatores como:

- facilidade e rapidez: o gênero jornalístico geralmente exige, na sua produção, menos recursos técnicos e de linguagem do que programas ficcionais, por exemplo. A maioria dos programas ficava pronta durante a própria gravação (em muitos casos não havia o exercício de edição; os depoimentos, comentários e respostas dos entrevistados entravam na íntegra no resultado final do programa, que era gravado na mesma ordem em que seria exibido). Além disso, a roteirização e o ensaio são realizados de maneira mais rápida no gênero jornalístico do que no ficcional, no de humor ou no de variedades;

- espírito crítico: adota-se a idéia de que por meio dos formatos que integram o gênero jornalístico, os educandos poderiam exercitar a opinião, o comentário, a argumentação, a relação entre fatos, a contextualização de temas e a escolha de pontos de vista. Tanto entre parte da equipe interna do projeto como também entre alguns professores cursistas, havia a sensação de que o gênero jornalístico propiciava mais chances de desenvolvimento da expressão oral e do espírito crítico, pois cada um que fala está “representando a si mesmo” e não a um personagem como na ficção, a qual era entendida, muitas vezes, mais como um exercício de linguagem sonora do que necessariamente de melhoria da 
capacidade expressiva dos jovens. Por outro lado, a convivência com os alunos e professores durante a realização dos programas mostrava que geralmente os programas que continham ficção e humor eram feitos de forma mais lúdica não só nos momentos de concepção e gravação como também na avaliação;

- gênero atual: o jornalismo é um gênero com presença marcante na história do rádio desde a primeira metade do século $\mathrm{XX}$ até os dias atuais (o que não ocorreu com outros gêneros e formatos como a ficção, por meio de radionovelas, os programas infantis e os educativos que praticamente desapareceram da grade de programação da maioria das emissoras). Quase todos os cursistas tinham referências sobre programas jornalísticos veiculados nas emissoras de rádio.

Se o gênero jornalístico demonstra ter presença marcante tanto na programação das emissoras comerciais como nas produções radiofônicas realizadas no projeto “educom.rádio”, o mesmo não podemos afirmar sobre o outro gênero que, no mercado radiofônico, rivaliza com o jornalismo pela posição de destaque junto ao ouvinte: o musical. Diagnosticamos nas diferentes fases do “educom.rádio” um baixo índice de programas predominantemente musicais (apenas 2,6\% do total) inclusive nas produções realizadas apenas por estudantes (que geralmente são ouvintes assíduos de programas e programações musicais).

Também chama a atenção a queda acentuada da proporção de programas musicais de 5,2\% nas fases 1 e 2 para apenas $1 \%$ na última fase. $\mathrm{O}$ resultado apresenta-se como conseqüência da preocupação das equipes do NCE-USP em alertar e conscientizar os cursistas de que o rádio na escola não precisa reproduzir a programação das emissoras 
comerciais nem se tornar apenas um aparelho de som para veiculação de músicas. A equipe do NCE-USP procurou, ao longo do “educom.rádio”, promover atividades práticas para estimular crianças, jovens e adultos a pensarem e produzirem programas mais complexos e elaborados do que a simples veiculação de músicas intercaladas pela fala de um ou dois locutores com algumas informações superficiais sobre as músicas tocadas (geralmente de grandes gravadoras da indústria fonográfica, como ocorre nas emissoras comerciais). ${ }^{122}$

\subsection{2 - A participação dos professores}

Quando comparamos os gêneros das produções realizadas sem a participação dos professores com aquelas em que os docentes foram co-autores e co-produtores chegamos à seguinte constatação: sem a presença dos professores, os alunos equilibraram a produção de programas de ficção e de variedades; já com a participação dos professores acentua-se a realização de programas de variedades em detrimento da ficção.

\begin{tabular}{|l|c|c|}
\hline & Variedades & Ficção \\
\hline Só alunos & $23,4 \%$ & $22,4 \%$ \\
\hline Alunos e professores & $30 \%$ & $15,7 \%$ \\
\hline
\end{tabular}

A preferência pelo gênero de variedades entre os professores reflete-se até no pequeno número de produções analisadas que foram realizadas apenas pelos docentes: dos 12 programas analisados, dez podem ser classificados como variedades.

\footnotetext{
122 - As equipes do NCE-USP tiveram a oportunidade de discutir com os cursistas a possibilidade de usar a rádio para abrir espaço às bandas e aos grupos musicais de alunos da própria escola, bem como para músicos da comunidade, que não conseguiam mostrar seu talento em emissoras comerciais.
} 
Outro gênero que ampliou sua predominância nos programas que contavam com a participação dos professores junto com os alunos foi o humorístico. Surpreende o baixo índice de programas de humor realizados apenas por alunos (apenas 1,7\% do total) tendo em vista que a maioria dos jovens demonstra mais interesse por emissoras FM com programas musicais e quadros humorísticos. O índice de predomínio de humor nas produções radiofônicas do “educom.rádio” quase triplicava com a participação de professores e funcionários saltando de 1,7\% para 4,5\%.

Por outro lado, a produção de áudios contendo apenas vinhetas (de programa ou da emissora da escola) concentrou-se nas atividades realizadas apenas pelos alunos. Das produções realizadas apenas por estudantes, 6,6\% corresponderam a vinhetas, ao passo que, nos programas conjuntos, o índice cai para 2\%. Esses dados reforçam a percepção que tínhamos ao acompanhar as atividades, de que tanto os professores quanto os próprios alunos acreditavam que a criação e a elaboração de vinhetas seriam responsabilidades dos jovens estudantes. No entanto, muitas vezes os mediadores das equipes do NCE-USP precisavam intervir a fim de evitar situações em que os adultos tentassem controlar o conteúdo e o roteiro, deixando para os alunos apenas a função de gravar as vinhetas.

Em relação às áreas temáticas dos programas podemos identificar três pautas que registraram crescimento de pelo menos $45 \%$ nas produções em que os professores se juntaram aos alunos em comparação aos programas realizados apenas por estudantes: “meios de comunicação”; “violência” e "política”.

\begin{tabular}{|l|c|c|c|}
\hline & $\begin{array}{c}\text { Meios de } \\
\text { comunicação }\end{array}$ & Violência & Política \\
\hline Só alunos & $3,3 \%$ & $7,6 \%$ & $5,6 \%$ \\
\hline Alunos e professores & $7,1 \%$ & $11,3 \%$ & $8,2 \%$ \\
\hline
\end{tabular}


Os dados mostram que, diferentemente do que muitos poderiam esperar, os programas realizados apenas por alunos não abusaram do tema da violência. As pautas relacionadas aos meios de comunicação cresceram com a participação dos professores provavelmente porque estes buscavam muitas vezes discutir leitura crítica dos meios de massa com os alunos. Dos temas que antecipadamente poderíamos supor que tivessem sido mais pautados devido à influência dos professores, o único que se confirmou foi o de "política". Em relação às opções temáticas dos programas realizados apenas por estudantes destacam-se os assuntos relacionados à arte e à cultura que estiveram presentes em 6,6\% das produções dos estudantes, superando o índice de 5,1\% registrado pelos programas que contaram com a participação de professores e funcionários.

Nesta análise temática, é importante registrar, ainda, o pequeno espaço dedicado ao tratamento de temas considerados "tabus", como "amor e sexualidade". Tal fato ocorreu tanto nas produções dos jovens $(1,3 \%)$ como naquelas realizadas em conjunto com os professores e funcionários (2\%). Uma das hipóteses, difícil de se mensurar na prática, que podemos tentar apontar para o baixo índice seria a timidez de muitos participantes, pois os programas quase sempre eram ouvidos na presença de outros cursistas, não só da mesma unidade escolar como de escolas próximas. Cientes de que a audição e avaliação dos programas provavelmente seriam realizadas coletivamente, muitos cursistas optavam por evitar temas polêmicos. Os programas realizados nos dias do eixo transversal sobre “diversidade e pluralidade” abordavam mais temas sobre preconceitos relacionados à questão racial do que sexual; produções radiofônicas relativas ao eixo transversal sobre saúde raramente tratavam de orientação sexual. 
Finalizamos nossa análise apontando para o acerto de muitas inovações ocorridas no projeto, o que ficou evidente pelos resultados mostrados pelo levantamento quantitativo, como, por exemplo:

a) o aumento das atividades práticas e da realização de programas de rádio ao longo do processo de capacitação;

b) a melhor distribuição de gêneros e de temas entre o começo e o final de cada fase do curso (sendo importante destacar que em nenhuma das fases analisadas o gênero ou tema predominante ultrapassou 50\%);

c) a grande quantidade de produções realizadas conjuntamente por alunos, professores e funcionários;

d) a criação de um setor no NCE-USP chamado "Memória Audiovisual” (responsável por digitalizar e catalogar as centenas de produções radiofônicas realizadas nos pólos onde o projeto era realizado).

No próximo capítulo, apresentaremos uma análise qualitativa sobre a continuidade das produções radiofônicas nas escolas após o término do projeto “educom.rádio”. Trata-se de uma oportunidade de não ficarmos restritos apenas aos "produtos", ênfase da análise quantitativa deste capítulo, mas de investigarmos principalmente os processos de comunicação nas escolas e os possíveis benefícios para o desenvolvimento do educando que se envolve com as produções radiofônicas no espaço escolar. 


\section{$\underline{\text { Capítulo } 6}$}

\section{Do uso do rádio ao uso da rádio: as produções radiofônicas nas escolas públicas de São Paulo após o projeto “educom”}

Este capítulo é dedicado à pesquisa de campo e à análise da realização de produções radiofônicas em algumas escolas da rede municipal de ensino de São Paulo que, após participarem do período de capacitação do projeto “educom.rádio”, deram, cada uma à sua maneira, continuidade às práticas educomunicativas, a partir de janeiro de 2005, já sem a assessoria do NCE/USP, cujo contrato com a Prefeitura findara em 31 de dezembro de 2004.

Preocupados com a mudança de orientação por parte da nova administração da Prefeitura de São Paulo, que optou por não mais contar com o apoio da Universidade de São Paulo no seguimento ao trabalho do “educom.rádio” nas escolas, buscamos elucidar se o projeto estaria tendo algum tipo de continuidade e, a partir da análise de uma amostragem, identificar quais seriam os atores das comunidades educativas envolvidos com as produções, como eles estariam interagindo e, também, diagnosticar se e como a escola expandiu as atividades de comunicação para outras linguagens além da radiofônica, como previa o projeto do NCE-USP. Pretendemos, ainda, com esta observação sobre o que remanesceu do "educom.rádio” na rede municipal, investigar as diferentes possibilidades de uso do rádio na escola com perspectivas pedagógicas e cidadãs, identificando os gêneros, formatos e temas predominantes na programação das emissoras escolares. 


\section{1 - Definição do universo e da amostragem}

O projeto efetivamente não desapareceu das escolas públicas após o término das capacitações. Enquanto, pela via jurídica, a FUSP buscava junto à Secretaria de Finanças da Prefeitura, formas de receber o que o NCE-USP tinha direito pelo trabalho executado na 7a fase, a Secretaria de Educação, por meio do trabalho do professor Jarbas Mazzariello, funcionário remanescente da administração anterior, realizava um levantamento preliminar sobre as práticas sugeridas pelo “educom.rádio” nas escolas. A enquete realizada em 2005 levou em conta apenas as 250 escolas que haviam recebido os equipamentos. Na verdade, a Prefeitura encontrava-se frente ao problema deixado pela administração anterior que não havia feito a licitação para a aquisição dos equipamentos de rádio destinado às demais 200 escolas (justamente as que participaram da 6a e 7a fases do projeto). O resultado foi considerado positivo ${ }^{123}$ : Das 250 escolas, 124 produziam programas radiofônicos, ou de forma regular ou, mesmo, de maneira esporádica. Foi o que informou a pedagoga Regina Célia Lico Suzuki, coordenadora de Ensino Fundamental da DOT (Diretoria de Orientação Técnica), conforme o professor Claudemir Viana, da equipe gestora do “educom.rádio”,

\footnotetext{
123 - Apesar de considerar o resultado como positivo, decidindo dar continuidade ao processo por meio de um novo projeto renomeado para "Educom nas ondas do rádio", a nova administração optou por não mais retornar ao tema da aquisição de equipamentos, deixando as 200 escolas das fases 6 e 7 à mercê da decisão das que haviam recebido o Kit e não o estavam usando, convidando-as a repassar os equipamentos para outra escola, interessada. O repasse ocorreu em apenas um caso. Com a atitude das novas autoridades um velho hábito da política foi registrado: a descontinuidade administrativa. Diante desse impasse, prejudicou-se uma rede de 199 escolas e cerca de quatro mil cursistas, entre professores, estudantes e membros das comunidades, que haviam sido capacitados durante o "educom.rádio".
} 
deixou registrado no site do projeto, após participar de reunião da Secretaria que havia discutido os resultados da referida enquete:

A professora Regina fez uma breve síntese do diagnóstico que a Secretaria fez em janeiro e fevereiro passados sobre o desenvolvimento do projeto Educom.rádio... Informou que 59 escolas desenvolvem projetos articulados ao PPP (Projeto Político Pedagógico), e que 65 escolas desenvolvem atividades esporádicas ${ }^{124}$.

Diante de um universo de 124 escolas, definimos como critérios para estabelecer uma amostragem significativa os seguintes elementos:

1) A não discriminação da fase em que a escola fez a capacitação presencial do “educom.rádio” (podem ser incluídas escolas de qualquer uma das sete fases do projeto);

2) A representação da diversidade geográfica que caracteriza a localização das escolas;

3) A existência entre as escolas a serem escolhidas de representação das unidades que não receberam o equipamento de rádio previsto no projeto;

4) O reconhecimento do poder público municipal quanto à eficácia do trabalho educomunicativo. A amostragem leva em conta uma relação atualizada das unidades escolares que, segundo a atual coordenação do projeto “Educom nas ondas do rádio” da Secretaria Municipal de Educação, vêm se destacando pelo compromisso de suas comunidades educativas em desenvolver ações e projetos voltados à produção radiofônica.

5) A ocorrência de procedimentos que indiquem a diversidade do projeto conforme as necessidades e as características de cada unidade escolar, tais como:

124 - Claudemir VIANA. Educom.rádio em debate. Acessado em 08/06/2005. Disponível em www.usp.br/educomradio/noticias/noticia2.asp?cod_not=1519. 
a) Escolas com produção radiofônica predominantemente relacionada às disciplinas curriculares e unidades escolares com programas de rádio voltados principalmente a temas extra-curriculares;

b) Escolas que receberam o kit completo com os equipamentos e escolas que não o receberam (pretendemos investigar se entre as 200 escolas que participaram do “educom.rádio”, mas não foram contempladas com a entrega dos equipamentos, existe alguma forma de prática educomunicativa por meio da realização de produções radiofônicas);

c) escolas que realizam programas de rádio freqüentemente e unidades escolares que fazem produções radiofônicas de forma esporádica.

Levando em conta, inicialmente, o terceiro critério (reconhecimento do poder público), partimos de uma relação de escolas apontadas pelo coordenador do programa "Educom nas ondas do rádio”, em 2006, o professor Carlos Alberto Mendes de Lima. Para ele, a presente pesquisa estaria construindo uma relação representativa se elegesse uma amostragem a partir das seguintes unidades:

- EMEF CEU Pêra Marmelo (Jardim Santa Lucrécia);

- $\quad$ EMEF Cidade de Osaka (Parque São Rafael);

- $\quad$ EMEF Dezoito do Forte (Vila Nagibe);

- EMEF Euclides de Oliveira Figueiredo (Cidade São Francisco);

- EMEF Fernando Gracioso (Jardim Russo);

- EMEF Imperatriz Leopoldina (Pirituba);

- EMEF José Bonifácio (Jardim Triana);

- EMEF Noé de Azevedo (Jardim Denise); 
- $\quad$ EMEF Padre José de Anchieta (Vila Progresso);

- EMEF Paulo Colombo Pereira de Queiroz (Parque Arariba);

- EMEF Pedro Teixeira (Jardim Santana);

- EMEF Professor Carlos Pasquale (Itaim Paulista);

- $\quad$ EMEF Raul de Eleoni (Vila Pedra Branca);

- EMEF Rui Bloem (Jardim Santo Elias);

- EMEF Vicente Amato Sobrinho (Jardim Meluinas).

De posse da relação destas 15 escolas e levando em consideração o conjunto dos critérios indicados, partimos para uma sondagem escola-por-escola, por meio de contatos telefônicos e via Internet, para conhecer os projetos de produção radiofônica desenvolvidos e, também, para apresentar os objetivos de nossa pesquisa, indagando dos responsáveis pelas produções radiofônicas sobre o interesse da escola em integrar nossa amostragem.

Das 15 escolas, identificamos quatro que, além de se integrarem no perfil definido pelos critérios estabelecidos, se dispuseram a contribuir com a pesquisa. É importante notar o fato de que as escolas finalmente selecionadas efetivamente representam realidades típicas de ordem geográfica: uma localizada no bairro Jardim Triana, no coração da Zona Leste; uma segunda, no Itaim Paulista, no extremo leste da cidade de São Paulo; uma terceira, na Zona Sul, entre Campo Limpo e Capão Redondo; e, finalmente, uma quarta, na zona Oeste, na região do Jaguaré. Infelizmente não foi viável, pelos critérios pré-estabelecidos, incluir representação da Zona Norte.

A amostragem passou, assim, a ser constituída pelas seguintes escolas: 


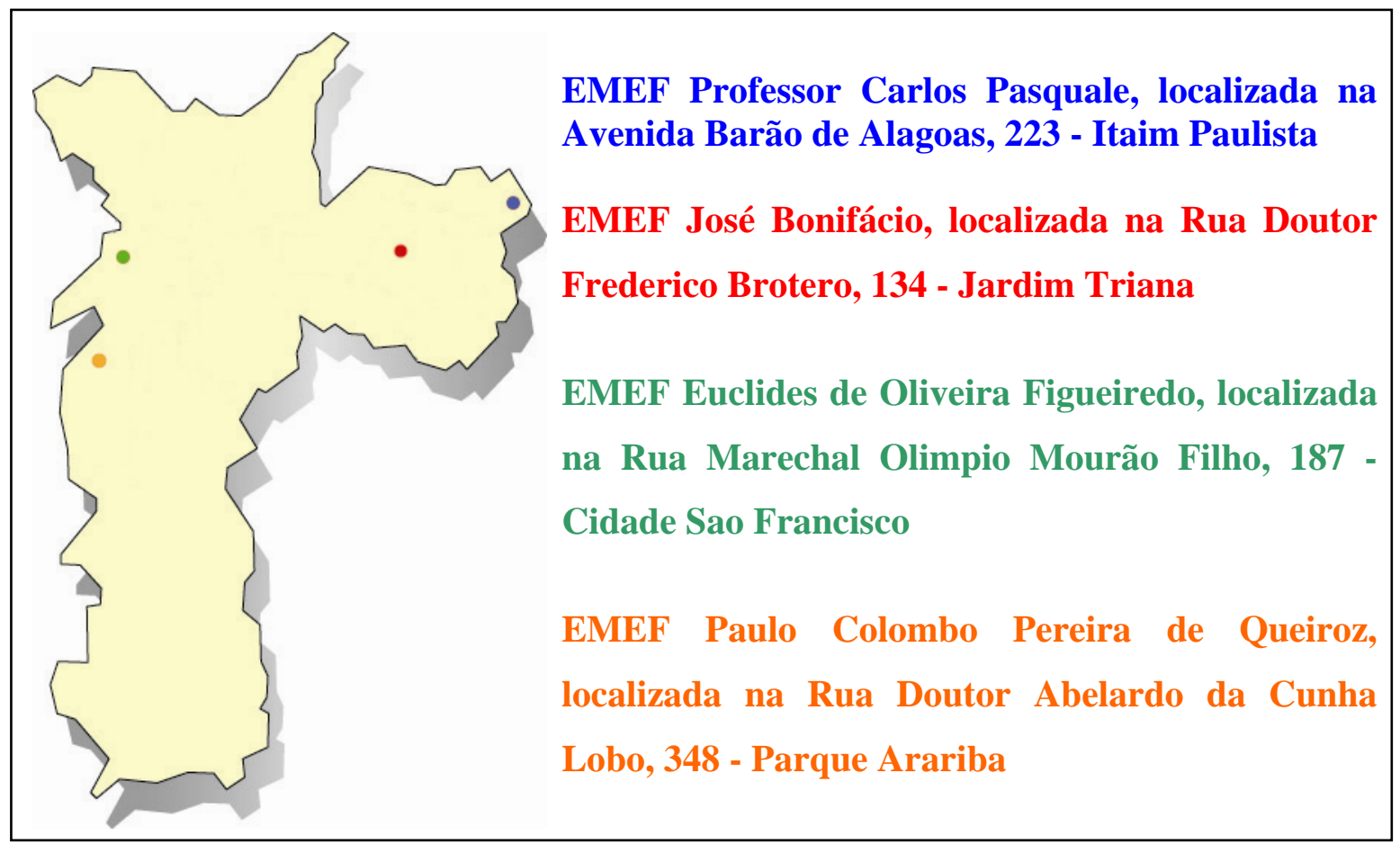

\section{2 - Procedimentos de pesquisa de campo}

Para realização da pesquisa de campo definimos quatro procedimentos básicos para coleta de dados e informações:

1) Visita às quatro escolas que compõem a amostragem;

2) Entrevistas com alunos, professores e coordenadores que participam das atividades de produção radiofônica nas escolas que integram a amostragem;

3) Aplicação de questionários sobre a participação e o desenvolvimento dos alunos que se envolvem com a realização de programas de rádio;

4) Entrevista com o coordenador do projeto "Educom nas ondas do rádio” na Secretaria Municipal de Educação. 


\subsection{1 - Visita às escolas}

Após entramos em contato por telefone e via Internet com as quatro escolas que compõem nossa amostragem, agendamos as visitas de acordo com a disponibilidade dos membros da comunidade educativa participantes das produções radiofônicas. Eis a ordem das visitas:

- EMEF Professor Carlos Pasquale (visita realizada em 29/11/2006). Localizada a 47 quilômetros da USP e a aproximadamente dois quilômetros da estação de trem “Itaim Paulista”, a escola está cercada por uma comunidade carente que não tem acesso a muitos bens e serviços de cultura e lazer. A EMEF atende a cerca de 2.000 estudantes, apresentando ótima infra-estrutura e bom estado de conservação. A solicitação de autorização para a visita foi feita por meio da oficineira responsável pelas atividades da rádio na escola ${ }^{125}$;

- EMEF Paulo Colombo Pereira de Queiroz (visitas realizadas em 01/12/2006 e 20/12/2006). Localizada a 18 quilômetros da USP, em uma região de difícil acesso, no Parque Arariba, a escola atende a cerca de 2.000 alunos, sendo que muitos são de famílias carentes. À noite, a escola disponibiliza muitas vagas de "EJA"

\footnotetext{
125 - "Oficineiro" é termo que designa uma pessoa externa às escolas e que, representando uma ONG contratada pela prefeitura por meio do projeto "São Paulo é uma Escola", desenvolve trabalhos de capacitação. Em algumas escolas, o oficineiro acabou sendo responsabilizado pela rádio, fato que, em alguns casos, eliminou o professor do processo de produção midiática. Quando isso ocorreu, a relação dos alunos se estabelecia com esta nova figura que, na maioria das vezes, mantinha-se alheia ao Projeto Político Pedagógico da escola. De acordo com a proposta educomunicativa, a solução representou um atraso conceitual, ainda que tenha possibilitado a permanência de algum tipo de produção radiofônica, especialmente onde a remoção de professores e a saída dos alunos que concluíam a 8a série acabavam por eliminar os protagonistas das ações previstas pelo projeto "educom.rádio". No caso, contudo, da EMEF Carlos Pasquale, os oficineiros (uma estudante de pedagogia já vinculada a programas pedagógicos da escola e um ex-aluno formado no "educom.rádio") acabaram sendo responsáveis pela continuidade de um projeto bem sucedido desde seu início,em 2002 (ver item "A Rádio Pasquale" deste capítulo).
} 
(Educação de Jovens e Adultos) também chamada de "Ensino Supletivo”. A região não oferece muitas opções de lazer e cultura para sua comunidade e é considerada violenta. O contato para o agendamento da visita foi estabelecido com a coordenadora pedagógica que participa das produções de rádio na escola;

- EMEF Euclides de Oliveira Figueiredo (visita realizada em 02/12/2006). Localizada a 8 quilômetros da USP, na região do Jaguaré, está perto da Avenida Corifeu de Azevedo Marques. A escola promove eventos abertos a comunidade para divulgar as iniciativas da equipe da rádio da qual participam vários ex-alunos. A visita foi agendada com o professor que coordena as atividades de comunicação na escola;

- EMEF José Bonifácio (visita realizada em 06/12/2006). Localizada a 32 quilômetros da USP e a cerca de 15 minutos da estação de metrô "Patriarca", a escola funciona em dois períodos, atendendo a aproximadamente 900 alunos. A solicitação de autorização da visita foi estabelecida com a auxiliar de direção que fez o contato com a professora que coordena as atividades de rádio e de jornalmural na escola.

Nas visitas pudemos conhecer os estúdios e os equipamentos das escolas, bem como ter acesso a outras mídias que interagem com a produção da rádio (como, por exemplo, o jornal-mural no pátio da EMEF José Bonifácio e as produções de fanzine, graffiti e material multimídia da EMEF Euclides de Oliveira Figueiredo).

Durante as visitas às EMEFs Professor Carlos Pasquale e Euclides de Oliveira Figueiredo foi possível acompanhar grupos de estudantes executando diferentes etapas do processo de realização radiofônica. 
As visitas foram fundamentais para conhecermos "in loco" as diferentes experiências de produção radiofônica e possibilitaram contato com membros de diversas instâncias das comunidades educativas. Durante as visitas realizamos entrevistas e aplicamos questionários, conforme discorreremos a seguir.

\subsection{2 - Entrevistas com membros da comunidade escolar}

Elaboramos um roteiro de perguntas abertas ${ }^{126}$ para os estudos de caso, com a intenção de contemplar tanto os aspectos relacionados às produções radiofônicas (temas, gêneros, durações, etc) como também às informações que dizem respeito à gestão da comunicação no espaço educativo, a fim de conhecer e analisar não só os produtos (os programas, a programação), mas também os processos de realização e participação.

O roteiro de perguntas foi elaborado para servir como um guia com indicação dos principais dados que gostaríamos de coletar, e não como uma "camisa de força”, tendo em vista que muitas das questões poderiam ser pautadas em outra ordem. O roteiro de perguntas também possibilitou que se aproveitassem os ganchos que surgissem nas respostas dos entrevistados.

Todos os depoimentos foram registrados em um gravador de áudio portátil tanto para servir como comprovação das falas quanto para viabilizar transcrições e futuras análises desta e de outras pesquisas que venham a ser desenvolvidas. As entrevistas foram, posteriormente, digitalizadas. Atualmente, estão disponíveis, em CDs, no acervo do NCE-

\footnotetext{
${ }^{126}$ - O roteiro com as perguntas abertas está disponível no anexo I, no final da dissertação.
} 
USP. Na presente dissertação, transcrevemos “ipsis litteris” os depoimentos de alguns alunos, professores e coordenadores nos tópicos referentes à descrição e análise do uso da rádio em cada escola e, também, no capítulo dedicado à análise dos questionários sobre o desenvolvimento dos estudantes.

O número de entrevistados variou em cada escola devido às circunstâncias de cada dia de visita como, por exemplo: ausência de alguns estudantes e coordenadores; horário de aulas; realização de provas; desenvolvimento de outras atividades na escola; chuvas fortes; etc. No entanto, conseguimos coletar depoimentos tanto de adolescentes quanto de adultos em todas as escolas pesquisadas.

Coletamos aproximadamente sete horas de entrevistas registradas em áudio, contendo depoimentos de 18 alunos e oito professores/coordenadores/funcionários, distribuídos da seguinte forma entre as escolas:

- EMEF Professor Carlos Pasquale: 9 alunos e 2 professores-oficineiros;

- EMEF José Bonifácio: 5 alunas e 2 professoras;

- EMEF Euclides de Oliveira Figueiredo: 3 alunos e 2 professores;

- EMEF Paulo Colombo Pereira de Queiroz: 1 aluno (coordenador da rádio da escola), 1 coordenadora pedagógica e 1 funcionário.

Das quatro, a EMEF Euclides de Oliveira Figueiredo foi a única que não foi contemplada com a entrega do Kit dos equipamentos por parte do poder público.

A descrição e análise das entrevistas sobre o uso da rádio de cada escola pesquisada serão apresentadas no ítem 6.3. 


\subsection{3 - Aplicação de questionários}

As visitas às escolas e as entrevistas possibilitaram que tivéssemos uma noção sistêmica do uso da rádio em cada unidade escolar. Optamos por utilizar questionários para pesquisar, com maior profundidade, o desenvolvimento dos estudantes que participam das produções radiofônicas.

Em três das quatro escolas visitadas, foi possível aplicar questionários com perguntas fechadas ${ }^{127}$, seguindo a escala Likert (com graus de concordância e discordância), que foram respondidos apenas por membros da comunidade escolar que se envolvem com as produções radiofônicas. Conseguimos coletar 55 questionários, dos quais:

- 40 foram respondidos por alunos;

- 15 foram respondidos por professores, coordenadores e funcionários.

A diferença numérica se explica pelo fato de que em todas as unidades escolares pesquisadas há muito mais alunos envolvidos com as produções radiofônicas do que professores, coordenadores e funcionários. Os questionários foram respondidos por membros da comunidade educativa das seguintes escolas:

- EMEF Professor Carlos Pasquale: 25 estudantes e 5 professores/coordenadores;

- EMEF José Bonifácio: 5 estudantes e 5 professores/coordenadores;

- EMEF Paulo Colombo Pereira de Queiroz: 10 estudantes e 5 professores/coordenadores.

\footnotetext{
127 - Os modelos dos questionários podem ser consultados nos anexos II e III da dissertação.
} 
Apenas na EMEF Euclides de Oliveira Figueiredo não conseguimos obter a devolutiva com os questionários respondidos. A visita foi realizada em um sábado em que foi montado um grande evento de apresentação dos projetos de comunicação da escola para a comunidade. Neste dia, os integrantes da equipe da rádio estavam trabalhando na realização do evento (que contou com apresentações multimídia e programas de rádio ao vivo). No próprio dia conseguimos entrevistar alguns alunos e conversar com os professores nos bastidores antes e após o evento. No entanto, não foi possível reunir alguns membros da equipe para preenchimento dos questionários e os mesmos foram entregues aos coordenadores dos projetos da rádio da escola. Contudo, eles não conseguiram, no período de férias, reunir os estudantes e outros professores para preenchimento dos questionários.

Os resultados e análises dos 55 questionários respondidos serão apresentados no próximo capítulo da dissertação.

\subsection{4 - Entrevista com o coordenador do projeto "Educom nas ondas do rádio”}

Além das visitas às escolas, julgamos necessário acrescentar em nossa pesquisa uma entrevista com o presidente do Comitê Gestor da Lei Educom, o professor Carlos Alberto Mendes de Lima, que também é um dos atuais coordenadores do projeto "Educom nas Ondas do rádio” na Secretaria Municipal de Educação da Prefeitura de São Paulo, ao lado do Prof. Jarbas Mazzariello. Em 2006, Mendes visitou 208 escolas que participaram do 
projeto “educom.rádio” para avaliar a continuidade ou não das práticas radiofônicas e oferecer orientações e assessorias a respeito das técnicas e linguagens de rádio.

É importante destacar a história de vida e a formação deste professor que desde 1997 trabalha com as tecnologias de comunicação na escola. Sua primeira experiência na área de mediação tecnológica ocorreu quando passou a oferecer a seus alunos a oportunidade de realizar produções radiofônicas durante as aulas de Inglês, matéria que lecionava em escolas públicas do governo do estado de São Paulo.

Mendes, que se define como "militante do uso das linguagens midiáticas na educação", passou, alguns anos depois, a trabalhar em escolas da Prefeitura de São Paulo e participou do projeto “educom.rádio” como cursista. Destacou-se por seu engajamento nas atividades realizadas durante o período de capacitação e também pelos projetos desenvolvidos posteriormente em escolas da região de São Miguel Paulista, principalmente na EMEF Professor Carlos Pasquale.

Nossa entrevista foi realizada no estúdio de rádio do Departamento de Jornalismo e Editoração da Escola de Comunicações e Artes da Universidade de São Paulo (CJE-ECAUSP), no final do segundo semestre de 2006. Os depoimentos de Mendes foram digitalizados e estão disponíveis, em CD, no acervo do NCE-USP. Na presente dissertação, transcreveremos “ipsis litteris” alguns depoimentos do professor no capítulo VIII, no qual apresentaremos um balanço das principais informações coletadas durante a entrevista. 


\section{3 - Sistematização dos dados colhidos por meio das visitas às escolas e das entrevistas com a comunidade educativa}

\subsection{1 - A “Rádio Pasquale”}

A EMEF Professor Carlos Pasquale participou do projeto “educom.rádio” em 2002, mesmo ano em que recebeu o kit completo com os equipamentos. Neste ano e no seguinte, houve uma intensa produção de programas de rádio alavancada por capacitações que um dos professores oferecia semanalmente sobre técnicas e linguagens radiofônicas. Era o início da "Rádio Pasquale”.

Com o passar do tempo, a equipe foi reduzida devido à saída de muitos alunos (que concluíram o Ensino Fundamental) e professores (que foram lecionar em outras escolas). Dos cursistas inscritos no “educom.rádio” em 2002 restaram, quatro anos depois, apenas a diretora e uma professora. A rádio passou por um período em que manteve somente alguns programas esporádicos. A partir de então, houve uma tentativa de trabalhar com alguns professores em sala de aula e novas equipes começaram a ser formadas.

A estudante de Pedagogia Érika Brasil, que entrou na escola como estagiária para fazer a ponte entre professores do Ciclo I ( $1^{\mathrm{a}}$ a $4^{\mathrm{a}}$ séries) e Ciclo II ( $5^{\mathrm{a}}$ a $8^{\mathrm{a}}$ séries $)$, foi contratada como "oficineira". A partir deste momento, a escola pôde colocar uma profissional responsável exclusivamente pelas atividades de rádio, orientando alunos de diferentes períodos. 
Junto a ela, somou-se um garoto de 17 anos, ex-aluno da própria escola, que havia sido capacitado por um professor cursista do “educom.rádio”. Luiz Fernando Alves, após ter desenvolvido atividades voluntárias na escola para fomentar a programação radiofônica, tornou-se “oficineiro” da EMEF Carlos Pasquale por meio do projeto "São Paulo é uma Escola” (programa da Prefeitura que visa a evitar que os alunos fiquem nas ruas fora do horário de aula).

É importante ressaltar que, neste projeto, cabe à direção da escola escolher que atividades serão desenvolvidas pelos “oficineiros” e em que áreas eles irão atuar. A direção da EMEF Carlos Pasquale percebeu a necessidade de contar com pessoas que pudessem dedicar-se aos projetos da rádio. Érika Brasil explica que os professores, além de ministrarem suas disciplinas, envolveram-se com outros projetos de "pré e pós-aula":

Acaba ficando para a rádio um tempo irrisório que mal dá para a gente trocar as informações. O grosso mesmo (avaliação, pesquisa, trazer coisas para os alunos, as aula em si dentro da rádio) ficou a critério dos oficineiros, porque a maioria dos professores tem a boa vontade de participar, mas o problema é tempo. Não se tem esse tempo dividido com a necessidade que a gente tem dentro da rádio. ${ }^{128}$

A Rádio Pasquale conta com o apoio da direção da escola. No entanto, a participação dos professores é pequena. No segundo semestre de 2006 havia cerca de 60 alunos envolvidos diretamente com a produção e transmissão radiofônica. A escola atende seus alunos em três períodos e apresenta duas novidades em seus intervalos: o primeiro aspecto a se destacar refere-se ao fato de que, em vez de um, existem quatro intervalos em cada

\footnotetext{
128 - Depoimento disponibilizado na faixa 1 do CD que acompanha esta dissertação.
} 
período, sendo um para cada série; o segundo aspecto a ser destacado é que muitos desses intervalos correspondem justamente aos momentos de transmissão ao vivo da "Rádio Pasquale”.

Os alunos que se envolvem com a rádio são divididos em pequenos grupos de quatro ou cinco componentes. As equipes se reúnem fora do horário de aula para montarem a pauta do programa seguinte. Há divisão de funções como “produtor”, “locutor” e "sonoplasta”. A definição dos temas dos programas e a forma de abordagem são discutidas por todos os integrantes da equipe. A oficineira Érika Brasil atua como mediadora, a fim de evitar que haja acúmulo de funções nas mãos de apenas um aluno e propõe sub-divisões do tema escolhido entre os integrantes de cada grupo.

Os nomes dos programas mudam conforme a equipe, pois são veiculados com o mesmo nome do grupo que os produz. No entanto, o nome da emissora escolar é mantido em todas as atrações: "Rádio Pasquale”. Os estudantes levam cerca de duas horas para montar, em grupo, a pauta de cada programa de 15 minutos que será transmitido ao vivo durante o intervalo. Os programas são monotemáticos com predomínio de veiculação de informações e músicas, as quais são escolhidas de acordo com o tema do programa do dia. A maioria dos grupos afirma que primeiro define o tema e, depois, os melhores gêneros e formatos para abordá-lo. Os alunos demonstram, ainda, uma preocupação constante em utilizar uma “linguagem jovem” para atingir o público adolescente.

A gente acha o assunto e aí vê se é melhor falar de uma forma informativa ou se depende da série. Geralmente, é mais informativo ${ }^{129}$ (Tamires Silva, 14 anos, $8^{\text {a }}$ série)

129 - Depoimento disponibilizado na faixa 2 do CD que acompanha esta dissertação. 
A gente já põe numa coisa espontânea e dinâmica para que todos aprendam e entendam ${ }^{130}$. (Glauco Roberto Gomes, 14 anos, $8^{\mathrm{a}}$ série)

Estes programas regulares são transmitidos ao vivo para as caixas acústicas espalhadas no pátio e em uma praça que há dentro da escola. Cada grupo transmite o programa no horário do seu intervalo, atingindo, assim, alunos da mesma série. A exceção fica por conta de alguns estudantes da $5^{\mathrm{a}}$ série que, além de realizarem programas para seus companheiros, também produzem para $1^{\mathrm{a}}$ e $2^{\mathrm{a}}$ séries, devido às dificuldades que os alunos mais novos têm para preparar e montar uma pauta de um dia para outro.

Alguns alunos da $5^{\mathrm{a}}$ série, que começaram a se envolver com programas de rádio quando estavam na $2^{\mathrm{a}}$ série, responsabilizam-se pela capacitação dos atuais alunos da $2^{\mathrm{a}}$ série, chamados na escola de “educomunicadores mirins”.

Há veiculação de programas de $2^{\mathrm{a}}$ à $5^{\mathrm{a}}$ feira nos três períodos em que a escola funciona (manhã, intermediário e tarde), em pelo menos um dos quatro horários de intervalo de cada período. Predominam as produções de alunos do Ciclo II ( $5^{\mathrm{a}}$ a $8^{\mathrm{a}}$ séries). Há um computador disponível no estúdio que é usado mais para edição de texto permitindo que os grupos salvem suas respectivas pautas. Desta forma, outras equipes podem consultar os arquivos e evitar a repetição de temas e assuntos. Os oficineiros e estudantes que se envolvem com a Rádio Pasquale têm a perspectiva de digitalizar as produções, mas ainda não usam softwares de edição para realização dos programas.

A Rádio Pasquale é gerida quase exclusivamente pelos alunos, visto que são raros os programas radiofônicos realizados como atividades vinculadas a uma determinada disciplina ou a um projeto desenvolvido por um professor. São geralmente os alunos que

\footnotetext{
130 - Depoimento disponibilizado na faixa 3 do CD que acompanha esta dissertação.
} 
procuram parceria com os professores de determinadas disciplinas (e não o contrário) dependendo do tema que abordarão no programa.

Eles têm uma função bem protagonista, são bem independentes para fazer o programa deles $^{131}$. (Érika Brasil, oficineira)

Devido ao fraco envolvimento dos professores nas atividades radiofônicas, a linha temática da "Rádio Pasquale" direciona-se mais para atualidades, assuntos do cotidiano e temas extra-curriculares. Os alunos apontam como temas mais abordados aqueles relacionados a sexualidade, violência, educação e política. Relatam experiências de programas sobre gravidez na adolescência, pautas do Congresso Municipal de Educação, ataques do PCC (Primeiro Comando da Capital) em São Paulo, pichação, crise da aviação, acidente com avião da Gol que vitimou 155 passageiros; além de programas especiais que abordaram a Idade Média e os anos 70, 80 e 90.

A participação de membros da comunidade ao redor da escola não é intensa. A produção e audição dos programas é restrita quase exclusivamente aos alunos, professores e funcionários. As exceções ficam por conta de alguns programas realizados pelos estudantes que já foram exibidos em outras escolas da região de São Miguel Paulista e em eventos educativos como congressos e seminários.

Os alunos que realizam produções radiofônicas passaram questionários nas salas de aula para sondar a preferência dos demais estudantes em relação aos estilos musicais que gostariam de ouvir. É importante destacar que os estudantes estabeleceram uma espécie de “código de ética” em relação à escolha e à veiculação de músicas, que inclui pesquisas que vão desde a ideologia das bandas até a tradução de músicas estrangeiras.

\footnotetext{
131 - Depoimento disponibilizado na faixa 4 do CD que acompanha esta dissertação.
} 
Todas as músicas que a gente fosse apresentar, a gente tinha que mostrar para a Érika, nossa professora da rádio. Aí ela falava para a gente pesquisar na internet a tradução. Se tivesse algo demoníaco ou palavrão, a música já era cortada... porque querendo, ou não, isso aqui é uma escola: a gente não vai colocar uma música falando "não sei quem se esfregando em não sei quem ${ }^{132}$ ”

(Gabriela da Silva Lopes, 14 anos, $7^{\mathrm{a}}$ série)

O “código de ética”, por orientação da direção da escola, veta o uso de "CD pirata”. Quando querem inserir uma música nos programas e não conseguem baixá-la da Internet (download), os estudantes afirmam que fazem uma "vaquinha” (cada um contribui com uma parte do valor) para comprarem o CD original do cantor ou do grupo musical.

Os estudantes demonstram preocupação em não tocar apenas músicas veiculadas pelas emissoras comerciais e procuram, quando possível, trazer CDs de bandas da região e da comunidade. No fomento à criação musical, a "Rádio Pasquale” tem dado uma importante contribuição a alguns alunos:

Além de a gente tocar a música que eles pedem, estamos formando bandas. A rádio está dando a oportunidade para a gente conseguir montar nossa banda, gravar um CD e tocar ao vivo também ${ }^{133}$.

(Gabriela da Silva Lopes, 14 anos, $7^{\mathrm{a}}$ série)

A avaliação dos programas é constante: na semana de veiculação os estudantes se reúnem com um dos oficineiros. No entanto, alguns alunos apontam que dentro do grupo avaliam mais o produto (o programa e sua transmissão) do que processo de realização.

\footnotetext{
132 - Depoimento disponibilizado na faixa 5 do CD que acompanha esta dissertação.

133 - Depoimento disponibilizado na faixa 6 do CD que acompanha esta dissertação.
} 
Paralelamente aos programas periódicos veiculados ao vivo, a "Rádio Pasquale” está desenvolvendo uma experiência de realização de um longo programa especial gravado juntando trechos produzidos por equipes de séries diferentes.

Além do rádio, outra mídia usada pela escola para melhorar o fluxo comunicativo das informações é um jornal impresso em formato tablóide. No entanto, este material não se enquadra nas propostas de práticas educomunicativas, pois o jornal, em 2006, foi produzido exclusivamente pelos professores, sem a participação de estudantes. No entanto, os alunos divulgam e comentam algumas informações do jornal nos seus programas de rádio. Quando foi criado, o jornal impresso "Pasquale Informa” era realizado conjuntamente por alunos de $7^{\mathrm{a}}$ e $8^{\mathrm{a}}$ séries que participavam de oficinas de Jornalismo e Língua Portuguesa oferecidas pelo mesmo professor ex-cursista do “educom.rádio" que elaborou capacitações de técnicas e linguagens radiofônicas. O jornal chegou a ganhar uma versão na internet (o "Pasquale Informa Online”) realizada em parceria com a equipe da sala de informática e aproveitando os serviços de um provedor gratuito, que depois se tornou pago dando fim à experiência. Portanto, dos meios de comunicação usados na escola, o rádio continua sendo o único que segue as propostas educomunicativas fomentando o protagonismo infanto-juvenil e colaborando para a melhoria da capacidade expressiva dos estudantes. 


\section{1b) A “Rádio Sensação”}

A EMEF Paulo Colombo Pereira de Queiroz participou do projeto “educom.rádio” em 2002, disponibilizando seu espaço físico como escola-pólo. No mesmo ano, realizou a festa de inauguração de sua rádio. Dos cursistas que participaram da capacitação em 2002, apenas quatro professores continuaram na escola até 2006. Todos os estudantes capacitados durante o projeto “educom.rádio” concluíram o Ensino Fundamental. No entanto, cinco deles retornam à escola para participar de algumas produções radiofônicas. Os atuais estudantes que realizam programas de rádio foram capacitados pelo secretário da escola, que participa ativamente das ações da rádio, e também por outros alunos.

A escola adaptou uma sala no pátio para montar o estúdio de sua emissora, que, após processo de votação que envolveu todas as turmas de estudantes, recebeu o nome de “Rádio Sensação”.

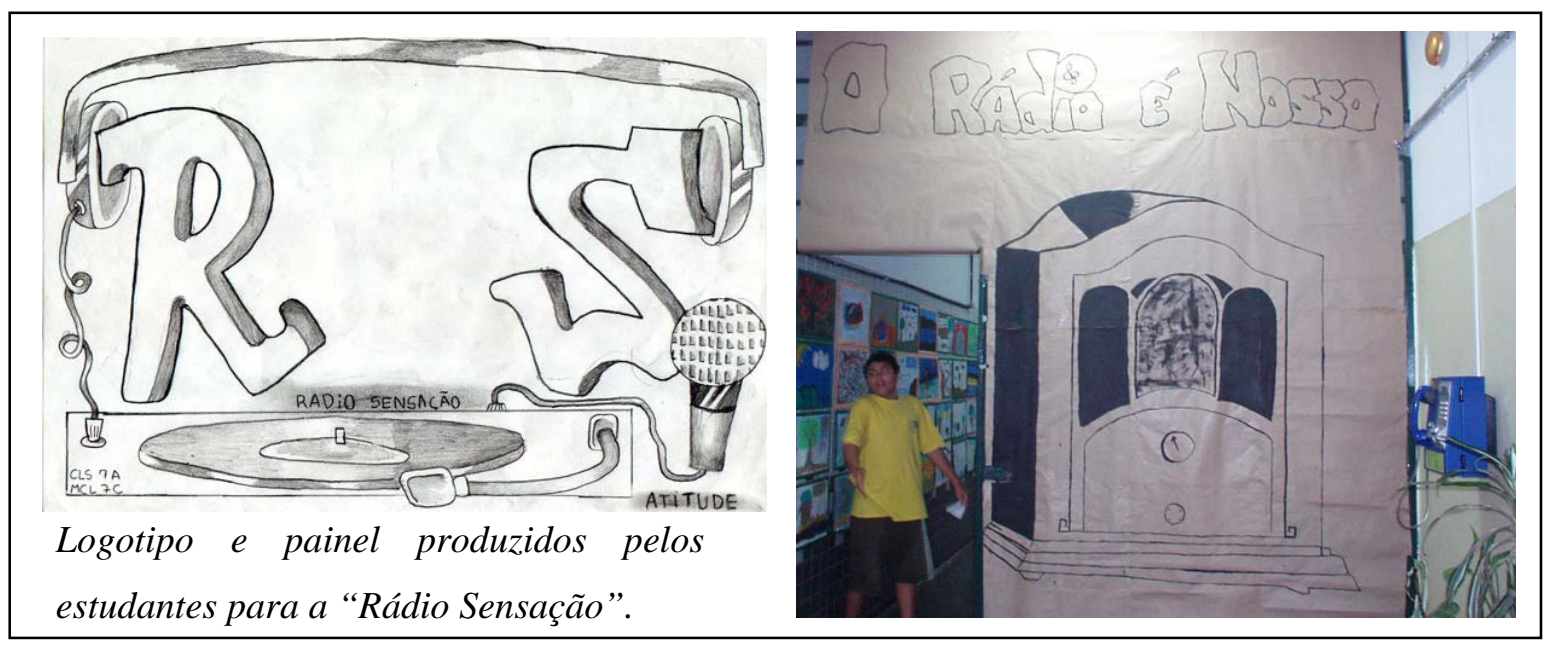

Além de contar com os equipamentos do kit do “educom.rádio”, a escola ampliou seu parque tecnológico adquirindo mais gravadores de mão, além de cabos e microfones, inclusive de lapela. Equipou seu estúdio com um computador possibilitando a edição não- 
linear de programas (por meio do software "Windows Movie Maker”) e gravação das produções em CD. No estúdio não é possível acessar a Internet. Contudo, os alunos que integram a chamada “equipe da rádio” têm autorização para pesquisar na web em um computador na sala da coordenação pedagógica.

A “Rádio Sensação” conta com uma equipe de 16 alunos com autorização para entrar no estúdio e operar os equipamentos. Esses alunos fazem escalas para atender a todos os períodos de funcionamento da escola (manhã, tarde e noite). À “equipe da rádio” são atribuídas muitas responsabilidades como:

- Produzir e transmitir programas com duração de 15 a 20 minutos durante os intervalos;

- Orientar e acompanhar as gravações de outros alunos e de professores. As etapas de definição da pauta, pesquisa e roteiro são realizadas, inicialmente, em sala de aula com o professor da disciplina. Com a pauta desenvolvida, alguns alunos vão ao estúdio acompanhar a gravação do programa feita pela equipe da rádio;

- Anunciar as atrações radiofônicas que serão transmitidas indicando seus realizadores;

- Ouvir e analisar os programas vinculados à determinada disciplina a fim de selecionar aqueles que julgam interessantes para serem transmitidos durante o intervalo de um ou mais períodos. Freqüentemente, por meio desse intercâmbio de material sonoro entre os períodos, alguns parentes conseguem ouvir as produções radiofônicas de seus familiares, como, por exemplo, pais do "Ensino Supletivo" que, à noite, escutam o programa realizado por seus filhos no período da manhã ou da tarde; 
- Preparar todo o esquema de transmissão sonora no pátio da escola, tanto para veiculação dos programas quanto para outras atividades que utilizem equipamentos sonoros;

- Assessorar professores que dão aula ou desenvolvem atividades no pátio usando equipamentos da rádio como, por exemplo, microfone de lapela no caso de uma professora que ensina técnicas orientais de relaxamento;

- Zelar pela qualidade sonora de filmes que são projetados em um grande pano branco estendido na frente do pátio. Trata-se do "Cine Graça Colombo”. O som da projeção dos filmes (cujas sessões são abertas à comunidade) é transmitido por meio das caixas acústicas da "Rádio Sensação",134;

- Gravar CDs com cópias dos programas para outros alunos e professores;

- Constituir e manter o acervo da rádio: salvar os programas em pastas no computador e em CDs, identificando os temas e formatos. Depois de transmitir programas ao vivo, a equipe realiza novamente o programa para gravação, aproveitando para corrigir eventuais falhas ocorridas na primeira transmissão;

- Elaborar e analisar pesquisas junto à comunidade escolar para sondar a preferência por gostos e estilos musicais. Por meio das pesquisas, a equipe procura adaptar a grade de programação musical ao perfil dos alunos dos diferentes períodos;

- Propor e viabilizar encontros com outras escolas para troca de informações a respeito dos projetos da equipe da rádio.

\footnotetext{
134 - É importante destacar o resgate cultural propiciado pelo envolvimento da equipe da rádio para desenvolver o projeto "Cine Graça Colombo". Coordenadores relatam que alguns alunos do "Ensino Supletivo", com mais de 50 anos, nunca tinham ido ao cinema antes desta experiência.
} 
Para lidar com os constantes atrasos dos professores, que não estavam com as pautas devidamente desenvolvidas no horário combinado para transmissão ao vivo, a “equipe da rádio” passou a privilegiar a gravação de programas em vez da realização ao vivo, garantindo, desta forma, que os programas transmitidos tivessem mais qualidade e coerência.

Os alunos decidem os formatos mais atrativos para abordar os temas escolhidos. Os programas realizados em parceria com as disciplinas curriculares são gravados para serem exibidos em sala de aula no horário de preferência do professor.

A “equipe da rádio” é formada, segundo a coordenação pedagógica da escola, por um grupo bem heterogêneo de alunos:

Nós temos desde meninos, excelentes alunos, comportadinhos, até o cara que veio da Febem. E aí vira uma mescla bem interessante, mesmo porque eles formam um grupo que, no ano passado, eles chamaram de "família Rádio Sensação", que você olhava era a coisa mais eclética do mundo. ${ }^{135}$ Célia Sevilha (coordenadora pedagógica)

A coordenadora pedagógica Célia Sevilha, uma das pessoas mais atuantes para viabilização da “Rádio Sensação”, explica que a escola entendeu que não seria possível que quase todos os alunos mexessem nos equipamentos devido ao tamanho reduzido do estúdio e às dificuldades operacionais que tal decisão implicaria. Ela esclarece que procura, geralmente, trazer para a “equipe da rádio” alunos que apresentam dificuldades de relacionamento e comportamento tanto dentro da sala de aula quanto fora da escola.

Uma parcela dos professores entende que o projeto é "superlegal” e que ele deveria ser um prêmio para o bom aluno. Nós temos uma concepção

\footnotetext{
135 - Depoimento disponibilizado na faixa 7 do CD que acompanha esta dissertação.
} 
diferente, que é exatamente o aluno que tem uma dificuldade na sala de aula. Esse menino, que tem dificuldade na sala de aula, é um menino que tem que fazer uma outra atividade a mais complementar. ${ }^{136}$

Célia Sevilha (coordenadora pedagógica)

Todos os alunos da "equipe da rádio” têm autorização dos pais para ficarem na escola fora do horário de aula. Alguns estudantes, segundo a coordenadora pedagógica, passam o dia inteiro na escola por causa da rádio, evitando, desta forma, que fiquem nas ruas expostos aos perigos da criminalidade da região.

A “equipe da rádio” ensina outros alunos a utilizarem os equipamentos, mas se responsabiliza pela operação dos mesmos. Essa equipe constantemente se reúne para avaliar seu trabalho e distribuir funções.

É importante destacar a paulatina distribuição de responsabilidades para os estudantes: no primeiro ano de funcionamento, o coordenador da rádio era um professor. No segundo ano, a "Rádio Sensação" era coordenada conjuntamente por um aluno e um professor. No terceiro ano, um aluno, escolhido democraticamente pelos colegas, passou a coordenar a rádio. Ele mantém contato com a coordenação pedagógica da escola a respeito da escala dos integrantes da equipe de acordo com a programação prevista para cada período e também informa sobre o uso e estado de conservação dos equipamentos.

Se a gente está em um lugar que a gente tem que criar responsabilidade, a gente tem que criar aquilo não para a gente, mas para os outros. Então tudo tem que ser com qualidade, responsabilidade e tem que ser sempre prazeroso. $^{137}$ (Felipe Alves, 14 anos, coordenador da "Rádio Sensação”)

\footnotetext{
136 - Depoimento disponibilizado na faixa 8 do CD que acompanha esta dissertação.

137 - Depoimento disponibilizado na faixa 9 do CD que acompanha esta dissertação.
} 
A divisão de funções na “equipe da rádio” causou, no início, uma diferenciação por sexo: as garotas faziam reportagens e entrevistas enquanto os garotos cuidavam mais da parte técnica. O grupo entendeu que, desta forma, não seria possível cobrir todas as etapas de realização em todos os períodos. A partir dessa constatação, os meninos ensinaram aspectos técnicos para as meninas, que, por sua vez, esclareceram para os garotos conceitos e práticas da linguagem jornalística.

A “Rádio Sensação” faz parte do Projeto Político-Pedagógico da escola. A cada reunião de começo de ano a coordenação mostra aos professores os projetos de rádio que foram desenvolvidos no ano anterior. Por sua vez, os professores também precisam informar e avaliar se, quanto e como desenvolveram ações utilizando os recursos da rádio.

Rádio é parte do projeto da escola. A escola Paulo Colombo tem um projeto chamado “educom”. Se eu venho trabalhar na Paulo Colombo, eu já sei que faço parte desse projeto, assim como eu tenho a sala de informática, a sala de leitura. $^{138}$

Célia Sevilha (coordenadora pedagógica)

Os professores são orientados a programar, dentro da sua área, atividades para aproveitar os recursos da "Rádio Sensação", podendo incluir no seu planejamento ações como adaptação de textos literários, realização de ficções radiofônicas, de programas de debates, etc. A intenção é que o professor insira as atividades relacionadas ao “educom” em seu planejamento no início do ano e combine no contato diário com a equipe da rádio as melhores formas e datas para viabilizar as ações.

\footnotetext{
138 - Depoimento disponibilizado na faixa 10 do CD que acompanha esta dissertação.
} 
Para a coordenadora pedagógica da escola, o esforço para propiciar ações educativas diferenciadas, por meio da rádio, é válido por potencializar o aprendizado dos alunos:

Tudo que é produtivo dá trabalho: mole é ficar lá enchendo lousa. Só que eu garanto que eles aprendem muito mais quando eles vão para o estúdio produzir seu trabalho, olham para ele, ouvem seu trabalho, quando o pai dele chega em casa e fala "escutei você na rádio". Eles aprendem muito mais. ${ }^{139}$ Célia Sevilha (coordenadora pedagógica)

A coordenadora explica que os alunos que não pertencem à “equipe da rádio” só vão ao estúdio para produzir e gravar determinado programa que já foi, anteriormente, pensado e planejado na sala de aula. Caberia, aí, o papel do professor de mediar o processo de concepção e realização dos programas radiofônicos. No entanto, Célia Sevilha destaca que não é fácil convencer a maioria dos docentes:

Os professores têm uma resistência ao projeto, que é a coisa do "fora da sala de aula": eles são seguros dentro da sua sala de aula; fazer alguma coisa fora da sua sala de aula já requer uma dinâmica diferente de trabalho. Aí eles ficam meio inseguros. ${ }^{140}$

Célia Sevilha (coordenadora pedagógica)

Os estudantes escrevem os roteiros dos programas e realizam os ensaios na sala de aula. Depois que as produções foram gravadas, alunos e professores pedem para a "equipe da rádio” inserir os programas na grade de programação. A “Rádio Sensação”, por meio das produções radiofônicas iniciadas nas salas de aula, já transmitiu programas com diferentes linhas temáticas, entre as quais destacam-se:

\footnotetext{
139 - Depoimento disponibilizado na faixa 11 do CD que acompanha esta dissertação.

140 - Depoimento disponibilizado na faixa 12 do CD que acompanha esta dissertação.
} 
- Eleição para assistente de direção: cobertura da rádio com informações sobre os candidatos, entrevistas e debate transmitido ao vivo. O debate foi gravado para ser veiculado aos alunos, professores e funcionários de outros períodos;

- Prevenção de doenças: programas realizados em parceria com as aulas de Ciências abordaram temas como Hepatite, Dengue e viroses. As produções foram exibidas em diferentes horários visando a conscientizar toda a comunidade escolar;

- Literatura de cordel: programas de rádio realizados com os alunos mais novos;

- Parlendas: gravações de pequenos textos literários rimados, brincando com palavras, usando um ritmo fácil e acelerado.

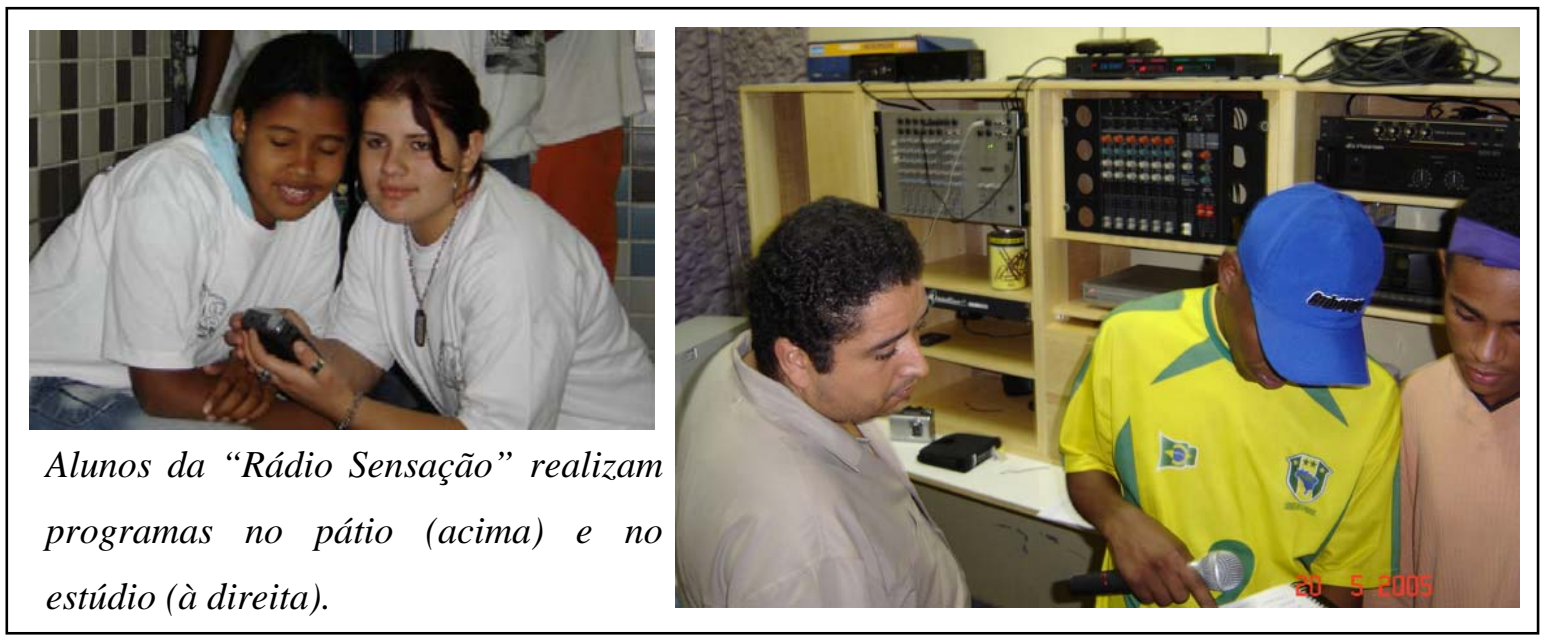

O projeto que deu mais visibilidade à "Rádio Sensação", mobilizando 400 alunos e 12 professores do turno da noite, foi um concurso de programas de rádio sobre desarmamento, realizado em 2005. Os grupos das diversas salas de aula tinham liberdade para escolher os gêneros e formatos dos programas. Depois de escrever o roteiro e de ensaiar, os alunos agendavam horário de gravação no estúdio com a "equipe da rádio". A coordenadora pedagógica, Célia Sevilha, explica que é preciso entender que projetos de realização radiofônica coletiva alteram a dinâmica da escola: 
Aí você vê um turno inteiro, 400 alunos, 12 professores, secretaria... todo mundo se virando para fazer. A dinâmica da escola muda completamente: você começa a ver menino no banheiro ensaiando, outro embaixo da escada, um aqui, o outro lá... e está todo mundo trabalhando. A princípio você olha e diz “meu Deus do céu: que bagunça é essa?”, mas está todo mundo trabalhando. ${ }^{141}$

Célia Sevilha (coordenadora pedagógica)

Sevilha ressalta o comprometimento dos estudantes em realizar programas de qualidade: Eles querem fazer muito bem. Eles não querem fazer bem, eles querem fazer o melhor. Teve grupo que fez música e passou oito vezes no estúdio. ${ }^{142}$ Célia Sevilha (coordenadora pedagógica)

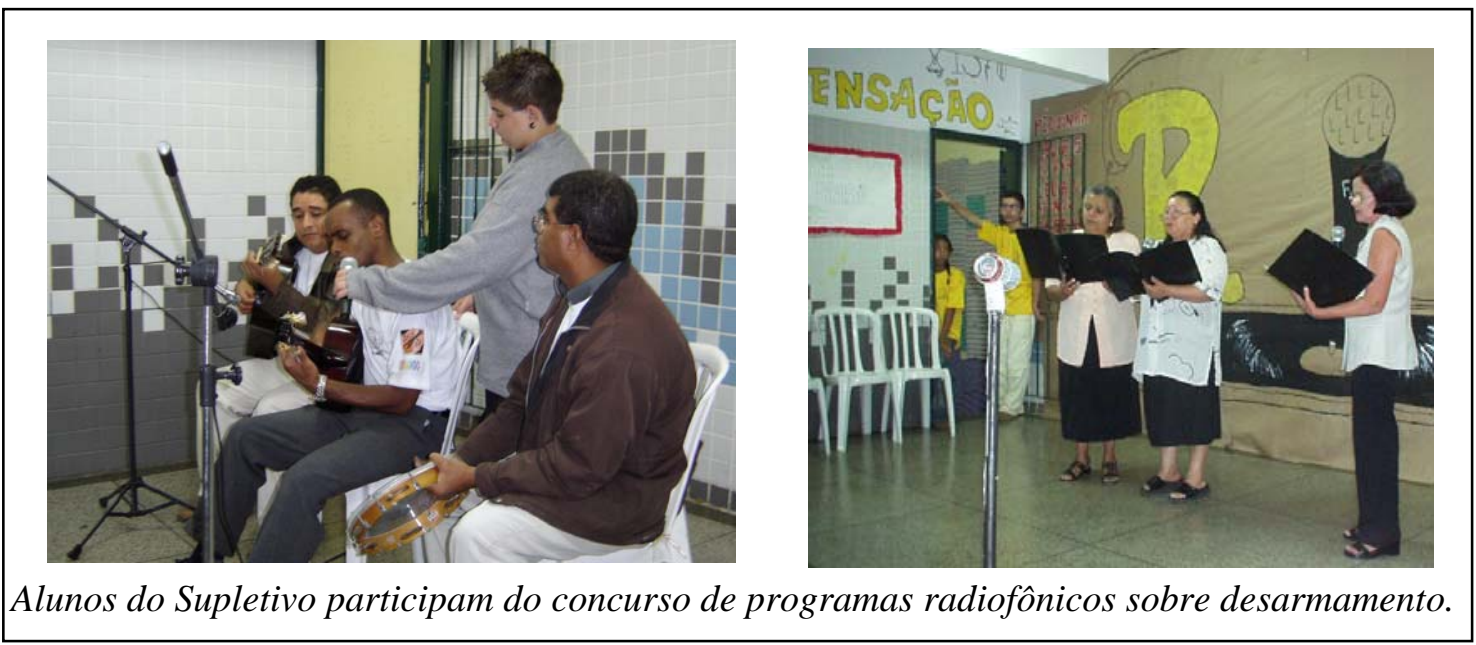

Na data da final do concurso, a "equipe da rádio" reuniu cerca de 400 pessoas da comunidade escolar no pátio da escola para audição coletiva dos programas que foram avaliados por jurados especialmente convidados. Sevilha destaca a contribuição de ações como essas para incentivar o processo de alfabetização de alunos do período noturno:

\footnotetext{
141 - Depoimento disponibilizado na faixa 13 do CD que acompanha esta dissertação.

142 - Depoimento disponibilizado na faixa 14 do CD que acompanha esta dissertação.
} 
Quem ganhou o concurso? A primeira série do EJA. Fizeram a música e a letra em uma semana e levaram mais um mês para escrever a letra efetivamente. Eles estão alfabetizando, mas queriam ter a letra no papel. ${ }^{143}$ Célia Sevilha (coordenadora pedagógica)

Quanto à manutenção dos equipamentos da rádio, Sevilha sugere que o poder público poderia viabilizar alguma forma de assessoria externa técnica, além de promover a visita às escolas de profissionais da área de rádio que poderiam levar mais informações aos alunos.

A coordenadora pedagógica critica a postura de escolas que receberam o kit de equipamentos do “educom.rádio”, mas não o utilizam, mantendo-o muitas vezes trancado, fora do alcance dos jovens.

Quais são os riscos? Os meninos quebram, os meninos são afoitos, não têm cuidado? São os riscos que você tem que trabalhar com o tempo. Se ele não pegar nunca, ele não vai quebrar nunca, mas também não vai fazer nunca. ${ }^{144}$ Célia Sevilha (coordenadora pedagógica)

Sevilha esclarece que todos os gastos com conserto dos equipamentos e aquisição de materiais para a rádio são justificados nas "Reuniões de Conselho" da escola. A coordenadora informa, ainda, que abre espaço para que os "funcionários operacionais" participem dessas reuniões. Desta forma, eles tomam ciência das ações da equipe da rádio, podem dar sugestões e planejar o desenvolvimento de suas funções levando em consideração a influência das atividades de prática radiofônica.

Numa escola você tem que envolver todo mundo porque você muda horário de merenda, de limpeza de banheiro, porque um está aqui e outro está lá,

\footnotetext{
143 - Depoimento disponibilizado na faixa 15 do CD que acompanha esta dissertação.

144 - Depoimento disponibilizado na faixa 16 do CD que acompanha esta dissertação.
} 
você muda a rotina da escola. Isso é uma dificuldade porque escola adora $\operatorname{rotina}^{145}$.

Célia Sevilha (coordenadora pedagógica)

O envolvimento dos funcionários e coordenadores ocorre não só no apoio operacional ou na viabilização de infra-estrutura, mas, também, por meio de participação nos programas:

Numa escola de 2.000 alunos, com um espaço enorme, a gente descobriu que a rádio é uma coisa muito interessante: hoje, desde a nossa diretora até o nosso companheiro da limpeza transmitem seus recados via rádio. ${ }^{146}$ Célia Sevilha (coordenadora pedagógica)

O principal objetivo da equipe da "Rádio Sensação” e da coordenação pedagógica é transformá-la, brevemente, em uma emissora comunitária de modo a atingir a população que vive ao redor da escola.

\section{1c) A “Rádio Boni”}

A EMEF José Bonifácio participou do “educom.rádio” em 2003. No entanto, as atuais coordenadoras das ações da rádio da escola (uma professora de Educação Artística e uma

\footnotetext{
145 - Depoimento disponibilizado na faixa 17 do CD que acompanha esta dissertação.

146 - Depoimento disponibilizado na faixa 18 do CD que acompanha esta dissertação.
} 
professora readaptada que se dedica exclusivamente ao projeto) fizeram o curso, em 2004, por outras unidades escolares.

Lígia Rodrigues, professora de Educação Artística, havia trabalhado ainda na Coordenadoria de Educação na área de projetos especiais e, desta forma, tinha contato com práticas vinculadas ao “educom.rádio”. Anna Maria Morais, professora de Inglês que foi readaptada para a escola, apresentou à direção da EMEF José Bonifácio a idéia de aproveitar melhor o equipamento de rádio. A proposta foi aceita e Anna Maria pôde passar a se dedicar exclusivamente aos projetos de produção radiofônica, sendo auxiliada por Lígia Rodrigues na coordenação das atividades de rádio.

Desta forma, o estúdio da escola, montado em uma sala onde antigamente funcionava um consultório dentário, passou a ser usado de maneira sistemática e organizada.

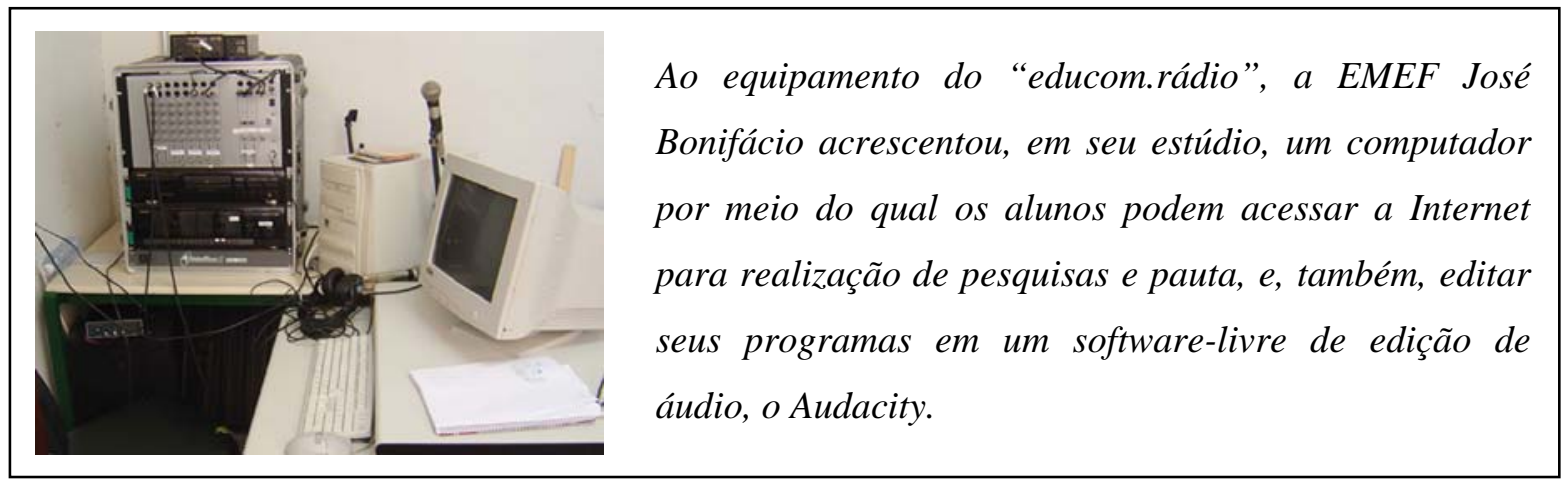

As duas coordenadoras fizeram convites a todas as séries a fim de conquistar alunos que gostariam de integrar a equipe da rádio. Foram montados, inicialmente, três grupos: um misto, um com estudantes da $8^{\mathrm{a}}$ série e outro com alunos da $5^{\mathrm{a}}$ série. Depois de alguns meses, esta última equipe foi a que teve participação mais efetiva na rádio. É importante destacar que, apesar de os alunos da $8^{\text {a }}$ série terem se desligado parcialmente do projeto, auxiliaram os estudantes da $5^{\mathrm{a}}$ série capacitando-os a respeito das técnicas radiofônicas, 
desenvolvendo, assim, o trabalho de multiplicação proposto pela equipe do NCE-USP durante o “educom.rádio”.

Os alunos que haviam participado da capacitação do projeto, em 2003, já haviam escolhido, por meio de eleição, o nome da rádio. Anna Maria e Lígia mantiveram a idéia de chamar a emissora da escola de "Rádio Boni”. A Coordenadoria de Educação auxiliou a retomada do projeto na escola contratando um locutor de rádio para ministrar oficinas.

A escola atende aos alunos em apenas dois períodos: manhã e tarde. As atividade da “Rádio Boni”, em 2006, concentraram-se no $2^{\circ}$ período, no qual estudam alunos de $5^{\mathrm{a}}$ à $8^{\mathrm{a}}$ séries, porque esse período corresponde justamente ao horário de trabalho de Lígia e de Anna Maria. A maioria dos programas foi realizada por alunos da $5^{\mathrm{a}}$ série.

Em 2006, a "Rádio Boni” desenvolveu ações relacionadas tanto a pautas vinculadas às disciplinas curriculares quanto a atividades extra-classe, como:

- Veiculação diária de músicas durante a entrada e o horário de intervalo do $2^{\circ}$ período;

- Realização de programas especiais com temática relacionada a datas comemorativas, como Dia das Mães e Natal;

- Produção de um programa-piloto sobre brincadeiras infantis para o público de $1^{\mathrm{a}}$ à $4^{\mathrm{a}}$ série;

- Realização de um programa especial sobre a história do rádio para exibição na “Mostra Cultural” da escola;

- Orientação e produção de programas vinculados a algumas disciplinas como:

- Ciências: produções sobre campanha de vacinação de idosos (os programas foram transmitidos para todas as turmas); 
- História: realização de programa sobre a importância de Tiradentes e da data comemorativa de 21 de abril;

- Língua Portuguesa: produções sobre o processo eleitoral. Os estudantes criaram seus partidos políticos e gravaram propagandas eleitorais e jingles.

- Cobertura radiofônica do Congresso Municipal de Educação atendendo a convite da coordenação do projeto “Educom nas ondas do rádio”.

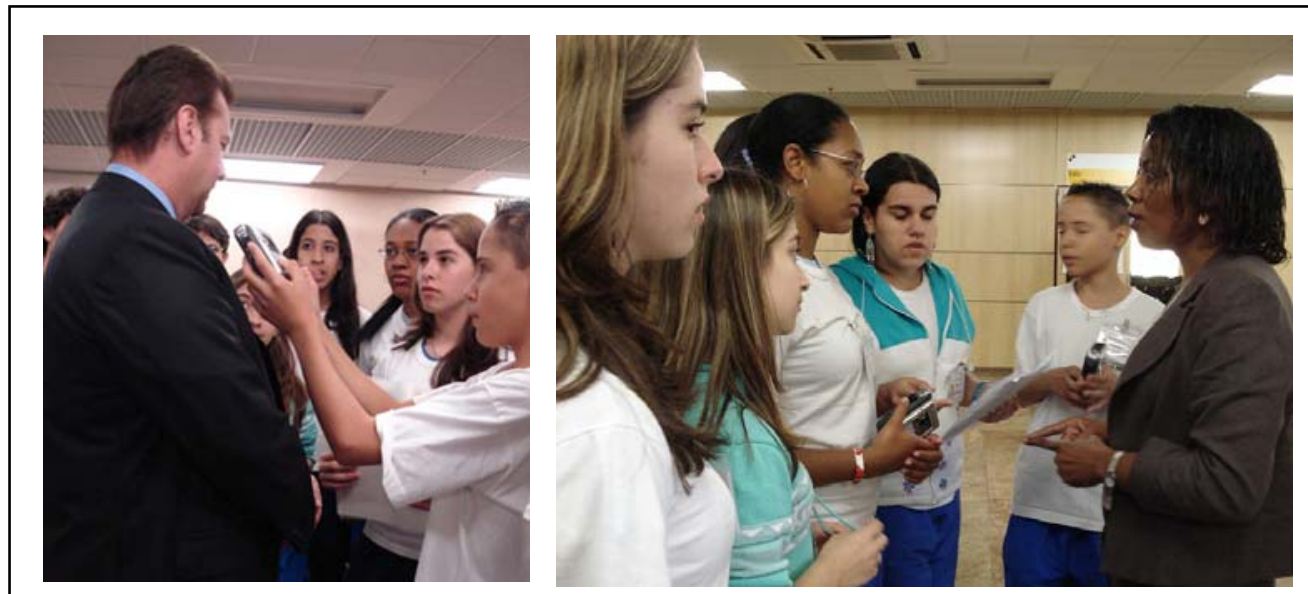

Alunos da "Rádio Boni" durante a cobertura do "Congresso Municipal de Educação”. À esquerda, entrevistam o prefeito de São Paulo, Gilberto Kassab.

Quando iniciaram as atividades de transmissão de programas durante a entrada e o intervalo do $2^{\circ}$ período, os alunos inseriam recados antes da veiculação de músicas. No entanto, devido a problemas de acústica no pátio, resolveram tocar apenas músicas.

Essa parte musical da entrada e do intervalo criou um vínculo interessante porque não só os alunos que fazem os programas e são responsáveis pela rádio, mas todas as classes interagem. Então, vem gente aqui de outras séries. $^{147}$

(Lígia Rodrigues, professora, coordenadora do projeto da "Rádio Boni”)

\footnotetext{
147 - Depoimento disponibilizado na faixa 19 do CD que acompanha esta dissertação.
} 
Uns pequenos grupos prestam mais atenção porque eles querem saber. Depois que passam os programas eles vêm perguntar como que a gente faz, como que a gente se organizou, como que foi... ${ }^{148}$

(Geisa Gonçalves, 11 anos, $5^{\mathrm{a}}$ série)

Junto com as coordenadoras dos projetos da rádio, os estudantes chegaram à conclusão de que programas falados requerem mais atenção e, portanto, deveriam ser exibidos nas salas de aula. No estúdio da "Rádio Boni”, a equipe guarda quatro caixas acústicas que são levadas para as salas de aula quando há transmissão de programas especiais.

Segundo a equipe da rádio, na sala de aula os alunos prestam mais atenção e ficam mais quietos durante a transmissão dos programas. É importante destacar que o trabalho com a linguagem radiofônica nas salas não se resume à audição de programas. Após a transmissão, ocorrem questionamentos e conversas sobre os temas entre os alunos e o professor que está na sala. Depois das primeiras experiências, a equipe da rádio optou por diminuir a quantidade de músicas nos programas veiculados nas salas atendendo à reivindicação de alguns professores, que alegavam que seus alunos ficavam muito agitados, dificultando a continuidade da aula. Paralelamente, a professora Lígia trabalhou, dentro de sua disciplina, com todas as classes de $5^{\mathrm{a}}$ à $8^{\mathrm{a}}$ séries, exibindo programas durante as aulas de Educação Artística.

A equipe da rádio é formada predominantemente por garotas. Os meninos que participam do projeto se interessam, quase exclusivamente, pela veiculação de músicas. As aulas dos alunos da rádio começam às 15hs. No entanto, eles chegam à escola, diariamente, às 13:45, para preparar as atividades da semana, produzir programas especiais e tocar as

\footnotetext{
148 - Depoimento disponibilizado na faixa 20 do CD que acompanha esta dissertação.
} 
músicas no horário de entrada. Os estudantes da equipe da rádio podem pegar a chave com uma das coordenadoras do projeto ou com o inspetor da escola e têm autorização para entrarem sozinhos no estúdio.

Muita gente ficou com medo: "Vou deixar os equipamentos com eles?”, “Ai! Vai ficar com eles a rádio?” Eu falei: “A rádio é deles! Eu já dei as coordenadas, agora eles têm que trabalhar. E eles têm que assumir essa coisa de responsabilidade com tudo que tem aqui com a palavra deles aqui dentro da rádio”. E eles têm respondido positivamente. ${ }^{149}$ (Anna Maria Morais, professora, coordenadora do projeto da "Rádio Boni”)

O cuidado dos estudantes com o estúdio incluiu até a melhoria da mobília. Os alunos da “Rádio Boni”, sob orientação da professora de Educação Artística, reciclaram parte dos móveis que conseguiram para o estúdio (uma mesa, uma cadeira e dois armários), por meio de uma técnica que utiliza coadores de café.

A avaliação e o planejamento do funcionamento da rádio são constantes. Semanalmente, a equipe da rádio se reúne com as professoras coordenadoras do projeto. Os alunos se preocupam também em realizar pesquisas com outros estudantes a fim de avaliar a opinião dos colegas sobre os programas especiais. A comunidade educativa também pode manifestar sua opinião enviando emails para a rádio, canal pelo qual é possível enviar sugestões de pautas e de músicas.

Predomina na programação da rádio da escola o gênero musical, veiculado diariamente. No entanto, as pautas relacionadas às datas comemorativas geralmente têm formato de programa de variedades, mesclando informação, música e humor.

\footnotetext{
149 - Depoimento disponibilizado na faixa 21 do CD que acompanha esta dissertação.
} 
Preocupados em conquistar os alunos da manhã, os estudantes da $5^{\mathrm{a}}$ série prepararam um programa especial sobre brincadeiras infantis para transmitir aos alunos de $1^{\mathrm{a}}$ à $4^{\mathrm{a}}$ série, que estudam no $1^{\circ}$ período. Além da veiculação do programa, convidaram os estudantes mais novos para conhecerem o estúdio da rádio e saberem como ela funciona. A intenção da equipe da rádio é agregar alunos do $1^{\circ}$ período tanto como ouvintes quanto na função de produtores e realizadores, aumentando o grupo que realiza produções radiofônicas, buscando garantir, desta forma, que os alunos mais novos possam dar continuidade às ações da rádio quando os mais velhos se formarem.

A equipe da “Rádio Boni” demonstra interesse em envolver também a comunidade externa, principalmente os pais de alunos. A primeira experiência nesse sentido foi a de realização de programas sobre a história do rádio, que puderam ser ouvidos em cabines equipadas com fones de ouvido, durante a "Mostra Cultural” da escola.

Segundo as coordenadoras Lígia e Anna Maria, o “educom” passou a fazer parte do Projeto Político-Pedagógico da escola e elas pretendem convencer mais professores a incluírem em suas atividades as ações relacionadas à linguagem radiofônica.

No projeto deste ano, vamos apresentar a linguagem jornalística e a linguagem radiofônica com um dos objetivos de leitura em sala de aula; de trabalhos de leitura e escrita. ${ }^{150}$

(Lígia Rodrigues, professora, coordenadora do projeto da "Rádio Boni”)

A “Rádio Boni” conta com o apoio da direção que, entre outras medidas, viabilizou a colocação de cortinas e de um ventilador no estúdio da rádio. Contudo, as coordenadoras ressaltam que é preciso contar com outros apoios além da direção:

150 - Depoimento disponibilizado na faixa 22 do CD que acompanha esta dissertação. 
Não adianta só a direção. Nós precisamos que toda a escola, toda a unidade escolar realmente entenda o projeto e nos apóie. A gente precisa de todo mundo para a manutenção do projeto. Dos colegas, nós temos um problema de sistemática da escola, a estrutura escolar, porque há, todo ano, mudança de professores. ${ }^{151}$

(Lígia Rodrigues, professora, coordenadora do projeto da "Rádio Boni”)

O projeto “educom” é forte. Ele ultrapassa a mudança de professor, de gestão e tudo mais porque o "educom" agora é lei. Então a gente se apega nisso para dar continuidade ao projeto. ${ }^{152}$

(Anna Maria Morais, professora, coordenadora do projeto da "Rádio Boni”)

As coordenadoras do "educom” na escola pretendem conquistar não só os professores “efetivos”, que permanecem na escola, mas também os “adjuntos” para que possam levar as idéias e práticas educomunicativas da rádio a outras escolas.

Em 2006, além das duas coordenadoras do projeto, mais dois professores se envolveram diretamente com as atividades de rádio e outros cinco docentes apoiaram e participaram de forma menos intensa.

Anna Maria acredita que o receio de mexer nos equipamentos é um dos principais empecilhos para a adesão de outros professores ao projeto:

Eu comecei mexendo aos poucos porque o equipamento, para mim, era um bicho de sete cabeças... A gente acha que é um monstro a princípio. Acho

\footnotetext{
151 - Depoimento disponibilizado na faixa 23 do CD que acompanha esta dissertação.
}

152 - Depoimento disponibilizado na faixa 24 do CD que acompanha esta dissertação. 
que o que distancia os professores do projeto é esse medo de mexer com o equipamento. ${ }^{153}$

(Anna Maria Morais, professora, coordenadora do projeto da "Rádio Boni”)

A veiculação de músicas pela "Rádio Boni” gerou, em alguns momentos, atritos com funcionários e alunos. A equipe da rádio afirma ter vivenciado, na prática, a dificuldade de agradar aos diferentes gostos musicais. Alguns coordenadores e professores chegaram a sugerir a troca das músicas selecionadas pelos alunos por outras mais lentas e calmas.

Às vezes a gente encontra certas dificuldades porque confundem o trabalho com bagunça. Às vezes não aceitam a música. Aí tenta colocar outro tipo de música, mas é música que o professor gosta ou o funcionário gosta. Isso também não vai resultar em nada.Então tem que fazer um trabalho de conscientização com os funcionários todos. ${ }^{154}$

(Anna Maria Morais, professora, coordenadora do projeto da "Rádio Boni”)

Uma das questões que a gente vai trabalhar o ano que vem é a conscientização da comunidade escolar sobre a importância do trabalho e também do respeito não só com o aluno, mas também da preferência, porque a rádio tem que ter uma certa autonomia nisso. Se ela está trabalhando com a comunidade escolar, ela tem que respeitar o gosto. Esse é um trabalho interno nosso de trabalhar também a conscientização dos funcionários e da equipe de apoio da rádio, que também tem que trabalhar junto com os alunos. $^{155}$

(Lígia Rodrigues, professora, coordenadora do projeto da "Rádio Boni”)

\footnotetext{
153 - Depoimento disponibilizado na faixa 25 do CD que acompanha esta dissertação.

154 - Depoimento disponibilizado na faixa 26 do CD que acompanha esta dissertação.

155 - Depoimento disponibilizado na faixa 27 do CD que acompanha esta dissertação.
} 
A equipe da rádio conseguiu ampliar suas ações comunicativas por meio da realização, manutenção e atualização de um jornal-mural no pátio da escola. Enquanto alguns estudantes produzem programas, outros preparam o jornal-mural que, segundo as coordenadoras do projeto, ajudou, inclusive, a trazer novos alunos para a equipe da rádio.

A gente tem o painel da rádio fixo lá fora. Então, fora esse trabalho com a rádio, eles fazem cartazes, notícias. Todo o material que vai ser preparado para programa também é editado aqui fora num jornal-mural. É responsabilidade deles ter sempre o painel modificado, atualizado, sempre com coisas de interesse da comunidade. ${ }^{156}$

(Lígia Rodrigues, professora, coordenadora do projeto da “Rádio Boni”)

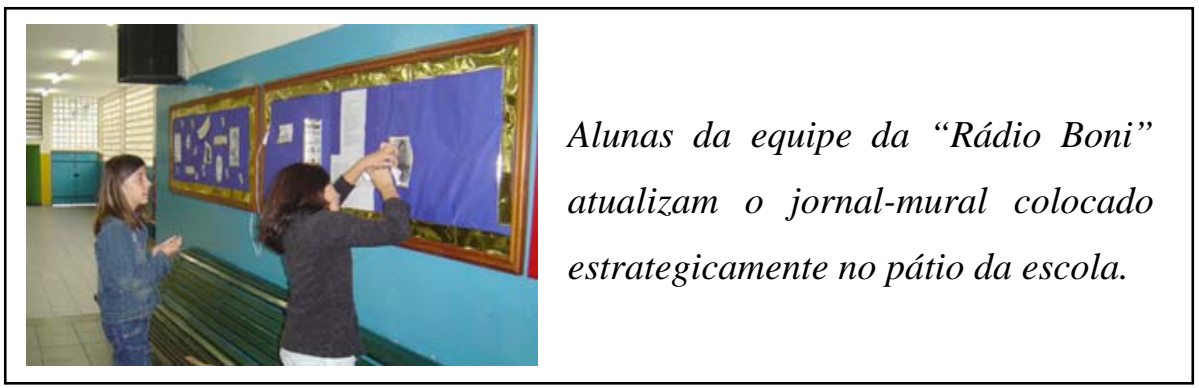

Lígia Rodrigues reforça ainda a importância dessas ações para desenvolver o senso de responsabilidade dos estudantes que assumiram o conceito “educom” em suas práticas:

E sempre com a assinatura do educom. Tudo o que eles produzem é da equipe do educom. Então, o importante é essa assinatura porque eles assumem a responsabilidade dos acertos e dos erros e também fica claro que é um trabalho deles. Não é um trabalho simplesmente de aluno. É um trabalho dessa equipe. ${ }^{157}$

\footnotetext{
156 - Depoimento disponibilizado na faixa 28 do CD que acompanha esta dissertação.

157 - Depoimento disponibilizado na faixa 29 do CD que acompanha esta dissertação.
} 
(Lígia Rodrigues, professora, coordenadora do projeto da "Rádio Boni”)

Em conjunto com as coordenadoras, os estudantes da "Rádio Boni” combinaram um código de conduta, válido para toda a escola, que inclui, principalmente, três restrições:

- comer no estúdio;

- acessar a Internet, no estúdio, para entrar em sites de relacionamentos ou de batepapo virtual;

- entrar no estúdio sem estar acompanhado de um integrante da equipe da rádio. Nesse sentido, combinaram que se houver algum dano ou furto a responsabilidade recairá sobre o aluno da equipe da rádio que estiver (ou que deveria estar) no estúdio naquele momento.

A “Rádio Boni” objetiva, a médio prazo, envolver o $1^{\circ}$ período (alunos e professores da manhã), transformar o programa-piloto sobre brincadeiras infantis em um programa periódico, descobrir novos talentos entre os estudantes e sistematizar uma programação diária que vá além da veiculação de músicas, sem deixar de lado a realização de programas especiais. A equipe avalia positivamente o ano de 2006 em que se empenhou na estruturação e divulgação da "Rádio Boni”:

Todos os alunos aqui do José Bonifácio têm conhecimento e já trabalharam de alguma forma. Com menor ou maior participação, já entraram em contato com o projeto. ${ }^{158}$

(Anna Maria, professora, coordenadora do projeto da “Rádio Boni”)

\footnotetext{
158 - Depoimento disponibilizado na faixa 30 do CD que acompanha esta dissertação.
} 


\section{1d) A “Rádio Interferência” e a "Rede Interferência”}

A EMEF Euclides de Oliveira Figueiredo foi inscrita na capacitação presencial do “educom.rádio” em 2003. Dos cursistas daquela época mantiveram-se na escola dois alunos, um professor e uma professora. Estes dois últimos são os atuais coordenadores dos projetos de comunicação e exercem funções diferentes na escola: o professor César atua como “apoio pedagógico” e leciona Geografia; a professora Regiane é auxiliar de período e instrutora da sala de leitura. Aos dois, juntou-se uma professora engajada no projeto, que leciona para a $4^{\mathrm{a}}$ série.

Entre as escolas visitadas para realização de nossa pesquisa, esta é a única que não foi contemplada com a entrega do Kit dos equipamentos por parte do poder público. No entanto, tal fato não impossibilitou que a escola passasse a realizar programas radiofônicos.

Interessada em dar continuidade às práticas educomunicativas, a comunidade escolar buscou viabilizar a idéia de ter sua emissora de rádio utilizando alguns equipamentos e aparatos técnicos de que dispunha, como amplificador, mesa de som, cabos, aparelho de som, microfones e três caixas acústicas. Os estudantes escolheram um pequeno espaço na lateral do pátio para servir de estúdio. Receberam permissão para guardar os equipamentos em uma pequena sala ao lado do local onde realizam os programas. Em virtude de não terem recebido o transmissor e a antena, viabilizaram a transmissão de programas por meio de cabos que conectam a mesa de som às três caixas acústicas estrategicamente colocadas no pátio. 
Logo no início das atividades, a equipe da rádio teve a preocupação de não usar sua emissora apenas para veiculação de músicas. A primeira experiência de transmissão foi a de um programa que, além da parte musical, apresentou vinhetas e trechos com narração.

Aí teve um dia que não teve a rádio. Aí o pessoal começou a vaiar, a fazer uma muvuca e a gente começou a conversar com eles: “a gente quer muito que vocês coloquem". Vieram até representantes do pátio conversar com a gente. Aí, colocamos de novo e foi muito legal. ${ }^{159}$

(Antônio Gustavo, 14 anos, 8a série)

Inicialmente, os estudantes realizaram programas com nomes diferentes, até tentarem fazer uma eleição para definir o nome da rádio, pedindo sugestões a outros alunos. Como a participação do restante da comunidade escolar não foi muito efetiva, decidiram reunir o grupo da rádio e decidir o nome da emissora. Aceitou-se a sugestão de um integrante da equipe que propôs “Rádio Interferência”.

Com o fortalecimento da rádio, os estudantes e os professores coordenadores passaram a vislumbrar a possibilidade de desenvolver novas experiências comunicativas e artísticas. Em pouco tempo, o grupo da "Rádio Interferência” se transformou em uma equipe multimídia, ganhando o nome de "Rede Interferência", que além dos programas radiofônicos passou a realizar:

- Jornal impresso em formato de fanzine com notícias, histórias em quadrinhos, desenhos;

- Pinturas e mensagens nas paredes da escola por meio do graffiti. A direção autorizou a intervenção artística na parede e os alunos se responsabilizaram pela compra das tintas e dos utensílios necessários;

\footnotetext{
159 - Depoimento disponibilizado na faixa 31 do CD que acompanha esta dissertação.
} 
- Fotos, notícias, comentários e desenhos para os murais da escola;

- Fotos, notícias, comentários e desenhos para serem colocados em uma vidraça da escola, localizada em uma área de passagem, que os alunos chamam de "vitrine”;

- Atividades que buscam promover palestras sobre temas transversais como diversidade racial, preservação do meio ambiente e orientação sexual;

- Apresentações multimídia (por meio do software Microsoft Office Power Point) com fotos, desenhos e músicas sobre temas transversais (como os citados no tópico anterior) e também sobre a história e os bastidores da própria “Rede Interferência”;

- Concurso de bandas musicais para alunos da escola e membros da comunidade.

Três anos depois da capacitação presencial do “educom.rádio”, a escola contou, em 2006, com uma equipe de 40 estudantes, três professores e dez ex-alunos que integraram a equipe da "Rede Interferência”, evidenciando o trabalho de multiplicação entre os estudantes e o vínculo criado com os alunos que concluíram o Ensino Fundamental. Alguns passaram a se envolver com a Rede Interferência após terem terminado a $8^{a}$ série:

Eu estudei aqui o ano passado, estou no Ensino Médio. Voltei para cá, esse ano, porque eu adorava o projeto. Eu nunca participei dele quando eu estava aqui na escola. Comecei a participar dele esse ano, agora que estou fora, porque acho muito interessante e é uma boa formação para o meu futuro. E para me divertir também. ${ }^{160}$

(Monise Sanches, 15 anos, ex-aluna)

\footnotetext{
160 - Depoimento disponibilizado na faixa 32 do CD que acompanha esta dissertação.
} 
Os alunos da "Rede Interferência" realizam o trabalho de capacitação de outros estudantes que passam a se integrar ao grupo. Explicam que fazem convites a alguns colegas que tenham “perfil de educomunicador”, cujas características, segundo eles, são:

Responsabilidade, saber o que faz, o que quer, não ficar de corpo mole, ter atitude, personalidade, ser diferente, criar muito, ser muito criativo. ${ }^{161}$ (Jade Daniela Rodrigues, 14 anos, $8^{\mathrm{a}}$ série)

A equipe da "Rede Interferência”, afirma ainda que não precisou escrever um código de ética com regras rigorosas, pois se pauta pelo bom senso e confia no grau de responsabilidade de cada integrante.

A "Rede Interferência” usa os meios de comunicação e as artes para promover a discussão e a conscientização a respeito de temas considerados transversais nos parâmetros curriculares. A EMEF Euclides de Oliveira Figueiredo pôde, a partir dessas experiências, vivenciar práticas relacionadas a duas importantes áreas propostas pela Educomunicação: a “mediação tecnológica na educação” e a “expressão comunicativa por meio das artes”.

A gente se baseia em formar "coletivos jovens". "Coletivos jovens" é o aluno poder discutir sua idéia com o professor, ele pôr sua idéia e não ficar na mesma aula de sempre: giz e lousa. ${ }^{162}$

(Antônio Gustavo, 14 anos, $8^{\mathrm{a}}$ série)

Durante os dias letivos, os alunos se organizam após horário de aula. As divisões na equipe não levam em conta as séries de cada estudante, mas a preferência dos alunos em relação aos temas que serão abordados.

\footnotetext{
161 - Depoimento disponibilizado na faixa 33 do CD que acompanha esta dissertação.

162 - Depoimento disponibilizado na faixa 34 do CD que acompanha esta dissertação.
} 
Além dos encontros durante os dias letivos, os estudantes se reúnem também aos sábados para desenvolver várias atividades da "Rede Interferência" como reuniões de formação, discussão de projetos, produção de conteúdo para as diferentes mídias, realização de planejamento, avaliação das ações implementadas, etc.

A “Rede Interferência” preocupa-se, também, em promover eventos para informar os pais e a comunidade externa à escola sobre as ações desenvolvidas.

No começo minha mãe reclamava que eu vinha direto e ficava até mais tarde. Mas, depois do primeiro encontro que ela veio e viu todos os projetos, a opinião dela mudou. ${ }^{163}$

(Monise Sanches, ex-aluna, 15 anos)

A "Rádio Interferência” funciona de $2^{\mathrm{a}}$ à $6^{\mathrm{a}}$ feira, com transmissão do mesmo conteúdo duas vezes por dia (nos intervalos do período da manhã e do turno da tarde). As duas transmissões, com duração de 15 minutos, são realizadas ao vivo. Desta forma, os programas, embora sigam o mesmo roteiro, não são exatamente iguais. Durante cada programa são veiculadas duas músicas. Para cada dia da semana elege-se, antecipadamente, um estilo musical. Os programas são voltados para o público jovem e alguns alunos dançam ao som das músicas tocadas no pátio.

Por meio de um acordo com um dos professores de História, os estudantes veiculam duas vezes por semana o quadro “MPB Compositor” com músicas e informações sobre artistas brasileiros como Almir Sater, Beto Guedes e Noel Rosa.

É importante destacar que, assim como ocorreu nas demais escolas pesquisadas, os estudantes da equipe da rádio consultaram os demais alunos para sondar sua preferência

\footnotetext{
163 - Depoimento disponibilizado na faixa 35 do CD que acompanha esta dissertação.
} 
musical. A "Rádio Interferência” elaborou um questionário contendo diferentes estilos de modo que os alunos pudessem indicar quais eram de seu agrado.

O pessoal da "Rede Interferência" não pode ter preferência. A gente aprendeu a curtir todos os estilos na "Rede Interferência". ${ }^{164}$

(Antônio Gustavo, 14 anos, $8^{\mathrm{a}}$ série)

Há poucas iniciativas de professores que propõe o desenvolvimento de um tema ou assunto de sua disciplina em forma de programas radiofônicos. Por meio de uma proposta de uma professora de Ciências surgiu a idéia de realizar programas e atividades sobre “consciência ecológica”. Já, uma professora de História sugeriu que se abordassem questões relacionadas à temática da “consciência negra”.

No entanto, geralmente, a abordagem dos temas parte dos alunos da "Rede Interferência" que, ao constatarem em sala de aula que determinado assunto poderia ser abordado em programas, levam a idéia para a reunião da equipe da rádio e, depois, para os docentes:

A gente, da Rede Interferência, procura os professores para fazer uma parceria, saber se eles querem, se estão interessados. ${ }^{165}$

(Antônio Gustavo, 14 anos, $8^{\mathrm{a}}$ série)

Os projetos da "Rede Interferência” são apoiados pela direção e pelas coordenadoras pedagógicas da escola. As ações comunicativas levaram a escola a ficar entre os finalistas de importantes premiações no setor educativo, tanto nacionalmente quanto internacionalmente. A coordenadora da escola foi representar a equipe da "Rede Interferência” em um prêmio de “comunicação escolar com jovens” em Lyon, na França.

\footnotetext{
164 - Depoimento disponibilizado na faixa 36 do CD que acompanha esta dissertação.

165 - Depoimento disponibilizado na faixa 37 do CD que acompanha esta dissertação.
} 
Na cidade de São Paulo, a EMEF Euclides de Oliveira Figueiredo foi indicada ao "Prêmio Paulo Freire”. Os estudantes da "Rede Interferência” foram convidados, ainda, a fazer a cobertura do evento da entrega do prêmio, realizada na Câmara Municipal. Lá, produziram um fanzine e programas de rádio.

Uma característica que ficou evidente na conversa com os estudantes da "Rede Interferência” diz respeito à relação de afetividade que mantém com o projeto:

A gente costuma falar que se não existisse a "Rede Interferência", nossa vida seria totalmente diferente, não teria graça alguma. ${ }^{166}$ (Jade Daniela Rodrigues, 14 anos, $8^{a}$ série)

É difícil um aluno da "Rede Interferência" não ter a "Rede Interferência" como uma das coisas mais importantes da vida. ${ }^{167}$

(Monise Sanches, 15 anos, ex-aluna)

A “Rede Interferência” pretende ampliar suas atividades para além dos muros da escola e, para isso, deu início ao processo de criação de uma ONG por meio da qual poderá ampliar a realização de eventos para a comunidade. A equipe ainda tem como objetivos a realização de um site e o investimento na profissionalização de seus estudantes em Comunicação e Artes, visando a abrir futuras portas no mercado de trabalho para os que desejam seguir carreira nessas áreas. A equipe da "Rede Interferência” se mostra constantemente aberta a desenvolver novas ações norteadas pelo aprimoramento da capacidade expressiva de crianças e jovens por meio da comunicação e das artes.

\footnotetext{
166 - Depoimento disponibilizado na faixa 38 do CD que acompanha esta dissertação.

167 - Depoimento disponibilizado na faixa 39 do CD que acompanha esta dissertação.
} 
Com o projeto que estamos montando da ONG nosso principal objetivo é divulgar a cultura, a arte e desenvolver o protagonismo do jovem. ${ }^{168}$ (Jade Daniela Rodrigues, 14 anos, 8a série)

No próximo capítulo discorreremos sobre como os projetos de rádio nas escolas pesquisadas podem, ou não, ter contribuído para o desenvolvimento dos alunos participantes que se envolveram com as práticas educomunicativas de produção radiofônica. Logo depois, no capítulo VIII, apresentaremos um panorama geral do uso do rádio nas escolas de Ensino Fundamental administradas pela Prefeitura de São Paulo, a partir da visão do poder público. Para encerrar, no último capítulo, dedicado às conclusões de nossa pesquisa, faremos uma análise das diferentes possibilidades de práticas educomunicativas vivenciadas nas escolas pesquisadas a partir do uso da linguagem radiofônica.

\footnotetext{
168 - Depoimento disponibilizado na faixa 40 do CD que acompanha esta dissertação.
} 


\title{
Capítulo 7 \\ O desenvolvimento dos jovens educomunicadores: a opinião de alunos e professores
}

\begin{abstract}
A relação entre o pensamento e a palavra é um processo vivo; o pensamento nasce através das palavras. Uma palavra desprovida de pensamento é uma coisa morta, e um pensamento não expresso por palavras permanece uma sombra. $^{169}$
\end{abstract}

(Lev Vygotsky)

\section{1 - Formulação e aplicação dos questionários}

Além de pesquisar os processos e os produtos da realização radiofônica nas escolas e sua relação com as práticas educomunicativas, também procuramos investigar o que muda em relação ao educando (crianças e jovens do Ensino Fundamental) a partir do momento que passa a se envolver com as produções de programas de rádio.

Nesse sentido, elaboramos um breve questionário com catorze afirmações sobre vantagens e benefícios que as práticas educomunicativas podem trazer ao educando, segundo a própria teoria da Educomunicação ${ }^{170}$. Objetivamos, nesse sentido, conhecer a opinião não só de professores e coordenadores a respeito do desenvolvimento de seus alunos, mas também a avaliação que o próprio educando faz de sua participação na

169 - Lev VYGOTSKY. Pensamento e linguagem. Ed. Martins Fontes, São Paulo, 2000, p.190

170 - Ismar de Oliveira SOARES. "Comunicação/Educação: a emergência de um novo campo e o perfil de seus profissionais”. In Revista Contato, ano 1, num. 2, Brasília, jan/mar 1999. 
realização de programas de rádio educomunicativos. Afinal, seria incoerente se ao abordarmos o protagonismo infanto-juvenil dermos espaço apenas à opinião dos adultos. Além disso, a afirmação de professores e coordenadores sobre o desenvolvimento do educando pode não ser percebida ou confirmada por seus alunos.

Além de investigar se as catorze afirmações teóricas são possíveis de serem constatadas, na prática, em projetos e ações que sigam as diretrizes educomunicativas, pretendemos pesquisar quais dos benefícios e das vantagens propostos pela Educomunicação para o desenvolvimento do educando são os mais expressivos e significantes na prática realista do dia-a-dia das escolas públicas pesquisadas.

É importante destacar que os questionários foram respondidos apenas por quem se envolveu com as produções radiofônicas, pois acreditamos que este critério é o mais coerente para possibilitar uma análise realista, evitando "achismos” daqueles que não se envolvem com projetos educomunicativos ou não têm muito contato com os jovens protagonistas.

Como pretendemos constatar a concordância (ou não) da comunidade escolar em relação aos possíveis benefícios para o educando em projetos de educomunicativos, julgamos que seria prudente evitar um questionário burocrático, apenas com itens como “concordo” ou “discordo”, o que dificultaria que as pessoas pesquisadas pudessem apontar quais vantagens foram as que realmente apresentaram maior impacto na formação e no desenvolvimento dos estudantes. Para tanto, baseamo-nos, em parte, na escala Likert. Trata-se de um método de pesquisa no qual os entrevistados são solicitados não só a 
concordarem ou discordarem das afirmações, mas também a informarem qual o seu grau de concordância/discordância. ${ }^{171}$

Os questionários ${ }^{172}$ foram aplicados nas quatro escolas visitadas para os estudos de caso de modo que as pessoas entrevistadas não precisassem se identificar, bastando colocar, no caso dos adultos, apenas a função exercida na escola, ou, no caso dos estudantes, a idade e a série. Principalmente no caso dos alunos, o sigilo visava a possibilitar que estes se sentissem mais à vontade para responder ao questionário; livres para apontar possíveis discordâncias, mesmo que estas dissessem respeito à participação dos professores ou de seus colegas.

171 - O método da escala Likert, proposto por Rensis Likert, em 1932, consiste, ainda, em atribuir a cada célula de resposta um número que reflete a direção da atitude do respondente em relação a cada afirmação a fim de constatar a pontuação total de cada frase por meio da soma das pontuações obtidas para cada assertiva. Não optamos por atribuir valores às respostas, mas por permitir que os entrevistados pudessem discordar totalmente, discordar em parte, concordar em parte, concordar totalmente, ou, até mesmo, nem concordar nem discordar da afirmação proposta.

172 - Os modelos dos questionários podem ser consultados nos anexos II e III da dissertação. 


\section{2 - Tabulação dos questionários}

Nas quatro escolas visitadas, conseguimos coletar, como já dissemos anteriormente, 55 questionários respondidos, sendo 40 por alunos e 15 por professores, coordenadores e funcionários.

Disponibilizamos, nas páginas seguintes, dois quadros, com dados porcentuais das respostas obtidas diretamente junto aos alunos e, depois, junto aos professores e funcionários, seguindo a ordem decrescente dos índices a partir da opção “concordo totalmente”.

Na primeira coluna são apresentadas afirmações que correspondem às expectativas inerentes aos objetivos da Educomunicação quando aplicada em ambiente escolar a partir do uso dos meios de comunicação. No nosso caso específico este meio é o rádio, ou a linguagem radiofônica nos moldes sugeridos pelo “educom.rádio”.

Advertimos, nesse sentido, que tais expectativas não são inerentes a qualquer prática radiofônica na escola, como as advindas de oficinas meramente técnicas, mas apenas à prática contextualizada no processo educomunicativo, que exige uma vigilância epistemológica sobre os procedimentos, especialmente a gestão democrática do processo comunicativo, com igualdade de condições e oportunidades para docentes e discentes no planejamento e execução do projeto no espaço escolar, de modo a formar um ecossistema comunicativo aberto e criativo. Seguem as tabelas: 


\section{Aos alunos:}

\begin{tabular}{|c|c|c|c|c|c|}
\hline \multirow{2}{*}{$\begin{array}{l}\text { Expectativa de mudanças de } \\
\text { comportamento com a integração } \\
\text { de crianças e jovens em processos } \\
\text { educomunicativos }\end{array}$} & \multicolumn{5}{|c|}{$\begin{array}{c}\text { Ao me envolver com a criação e produção de programas } \\
\text { de rádio na escola.... }\end{array}$} \\
\hline & $\begin{array}{c}\text { Discordo } \\
\text { totalmente }\end{array}$ & $\begin{array}{l}\text { Discordo } \\
\text { em parte }\end{array}$ & $\begin{array}{c}\text { Nem } \\
\text { discordo } \\
\text { nem } \\
\text { concordo } \\
\end{array}$ & $\begin{array}{l}\text { Concordo } \\
\text { em parte }\end{array}$ & $\begin{array}{l}\text { Concordo } \\
\text { totalmente }\end{array}$ \\
\hline $\begin{array}{l}\text { Consigo aprender e me divertir ao } \\
\text { mesmo tempo quando faço os } \\
\text { programas. }\end{array}$ & - & - & - & $5 \%$ & $95 \%$ \\
\hline $\begin{array}{l}\text { Tenho desenvolvido mais minha } \\
\text { criatividade. }\end{array}$ & - & - & $7,5 \%$ & $10 \%$ & $82,5 \%$ \\
\hline $\begin{array}{l}\text { Fiquei mais preparado para fazer } \\
\text { leitura crítica dos meios de } \\
\text { comunicação. Tenho mais noção de } \\
\text { como se fazem programas e como se } \\
\text { escolhem os temas. }\end{array}$ & - & - & $7,5 \%$ & $15 \%$ & $77,5 \%$ \\
\hline $\begin{array}{l}\text { Aprendi a trabalhar melhor em } \\
\text { grupo, cooperando com meus amigos } \\
\text { e colegas. }\end{array}$ & - & $2,5 \%$ & $2,5 \%$ & $20 \%$ & $75 \%$ \\
\hline $\begin{array}{l}\text { Preocupo-me em pesquisar os } \\
\text { assuntos e temas que serão abordados } \\
\text { nos programas. }\end{array}$ & - & $2,5 \%$ & $2,5 \%$ & $20 \%$ & $75 \%$ \\
\hline $\begin{array}{l}\text { Estou me sentindo menos tímido e } \\
\text { mais solto para falar em público e } \\
\text { dialogar com as pessoas. }\end{array}$ & - & $2,5 \%$ & $5 \%$ & $20 \%$ & $72,5 \%$ \\
\hline $\begin{array}{l}\text { Percebo que estou mais preparado } \\
\text { para saber selecionar e organizar } \\
\text { informações. }\end{array}$ & - & - & $7,5 \%$ & $22,5 \%$ & $70 \%$ \\
\hline Percebo que fiquei mais responsável. & $2,5 \%$ & $2,5 \%$ & $5 \%$ & $20 \%$ & $70 \%$ \\
\hline $\begin{array}{l}\text { Sinto-me mais feliz e motivado ao } \\
\text { saber que outras pessoas estão } \\
\text { ouvindo o programa em que aparece } \\
\text { minha voz ou que eu ajudei a fazer. }\end{array}$ & $5 \%$ & - & $7,5 \%$ & $17,5 \%$ & $70 \%$ \\
\hline $\begin{array}{l}\text { Melhorei minha capacidade de } \\
\text { questionar, criticar e argumentar. }\end{array}$ & $2,5 \%$ & - & $5 \%$ & $25 \%$ & $67,5 \%$ \\
\hline $\begin{array}{l}\text { Percebo que os professores que se } \\
\text { envolvem com a rádio me respeitam } \\
\text { mais e dão espaço para eu expressar } \\
\text { minhas idéias. }\end{array}$ & - & $2,5 \%$ & $15 \%$ & $17,5 \%$ & $65 \%$ \\
\hline Estou mais atento e disciplinado. & $5 \%$ & $5 \%$ & $7,5 \%$ & $20 \%$ & $62,5 \%$ \\
\hline $\begin{array}{l}\text { Estou mais consciente sobre o que } \\
\text { acontece na escola e na comunidade } \\
\text { ao redor dela, tenho mais contato } \\
\text { com a comunidade. }\end{array}$ & - & $2,5 \%$ & $17,5 \%$ & $17,5 \%$ & $62,5 \%$ \\
\hline $\begin{array}{l}\text { Percebo que melhorou minha relação } \\
\text { com os professores e funcionários. }\end{array}$ & $7,5 \%$ & $2,5 \%$ & $12,5 \%$ & $35 \%$ & $42,5 \%$ \\
\hline
\end{tabular}


Aos professores e funcionários:

\begin{tabular}{|c|c|c|c|c|c|}
\hline \multirow{2}{*}{$\begin{array}{l}\text { Expectativa de mudanças de } \\
\text { comportamento com a integração } \\
\text { de crianças e jovens em processos } \\
\text { educomunicativos }\end{array}$} & \multicolumn{5}{|c|}{$\begin{array}{l}\text { Observando e convivendo com crianças e jovens que } \\
\text { produzem programas de rádio na escola, percebo que: }\end{array}$} \\
\hline & $\begin{array}{l}\text { Discordo } \\
\text { totalmente }\end{array}$ & $\begin{array}{l}\text { Discordo } \\
\text { em parte }\end{array}$ & $\begin{array}{c}\text { Nem } \\
\text { discordo } \\
\text { nem } \\
\text { concordo } \\
\end{array}$ & $\begin{array}{c}\text { Concordo } \\
\text { em parte }\end{array}$ & $\begin{array}{l}\text { Concordo } \\
\text { totalmente }\end{array}$ \\
\hline $\begin{array}{l}\text { Os alunos aprenderam a trabalhar } \\
\text { melhor em grupo, cooperando com } \\
\text { seus amigos e colegas. }\end{array}$ & - & - & - & $13,3 \%$ & $86,6 \%$ \\
\hline $\begin{array}{l}\text { Os estudantes ficaram mais } \\
\text { conscientes sobre o que acontece na } \\
\text { escola e na comunidade ao redor dela, } \\
\text { têm mais contato com a comunidade. }\end{array}$ & - & - & - & $13,3 \%$ & $86,6 \%$ \\
\hline $\begin{array}{l}\text { Os estudantes se sentem mais felizes e } \\
\text { motivados ao saber que outras pessoas } \\
\text { estão ouvindo programas em que } \\
\text { aparecem sua voz ou que ajudaram a } \\
\text { fazer. }\end{array}$ & - & - & - & $13,3 \%$ & $86,6 \%$ \\
\hline $\begin{array}{l}\text { Os estudantes conseguem aprender e } \\
\text { se divertir ao mesmo tempo quando } \\
\text { fazem os programas. }\end{array}$ & - & - & - & $20 \%$ & $80 \%$ \\
\hline $\begin{array}{l}\text { Os professores que se envolvem com } \\
\text { a rádio respeitam mais os alunos e dão } \\
\text { espaço para eles expressarem suas } \\
\text { idéias. }\end{array}$ & - & - & - & $20 \%$ & $80 \%$ \\
\hline $\begin{array}{l}\text { Os alunos melhoraram sua capacidade } \\
\text { de questionar, criticar e argumentar. }\end{array}$ & - & - & - & $20 \%$ & $80 \%$ \\
\hline $\begin{array}{l}\text { Os alunos estão menos tímidos e mais } \\
\text { soltos para falar em público e dialogar } \\
\text { com as pessoas. }\end{array}$ & - & - & - & $26,6 \%$ & $73,3 \%$ \\
\hline $\begin{array}{l}\text { Os estudantes desenvolvem mais a } \\
\text { criatividade. }\end{array}$ & - & - & - & $26,6 \%$ & $73,3 \%$ \\
\hline $\begin{array}{l}\text { Os estudantes se preocupam em } \\
\text { pesquisar os assuntos e temas que } \\
\text { serão abordados nos programas. }\end{array}$ & - & - & - & $33,3 \%$ & $66,6 \%$ \\
\hline $\begin{array}{l}\text { Os alunos estão mais preparados para } \\
\text { selecionar e organizar informações. }\end{array}$ & - & - & - & $33,3 \%$ & $66,6 \%$ \\
\hline $\begin{array}{l}\text { Os alunos estão mais preparados para } \\
\text { fazer leitura crítica dos meios de } \\
\text { comunicação. Têm mais noção de } \\
\text { como se fazem programas e como se } \\
\text { escolhem os temas. }\end{array}$ & - & $13,3 \%$ & - & $26,6 \%$ & $60 \%$ \\
\hline Os alunos ficaram mais responsáveis. & - & - & - & $46,6 \%$ & $53,3 \%$ \\
\hline $\begin{array}{l}\text { Melhorou a relação dos alunos com os } \\
\text { professores e funcionários. }\end{array}$ & - & - & $6,6 \%$ & $46,6 \%$ & $46,6 \%$ \\
\hline $\begin{array}{l}\text { Os estudantes estão mais atentos e } \\
\text { disciplinados. }\end{array}$ & - & - & $6,6 \%$ & $80 \%$ & $13,3 \%$ \\
\hline
\end{tabular}


Após apresentarmos a tabulação com o percentual de cada resposta possível, disponibilizamos uma tabulação mais resumida, excluindo os índices de "nem discordo, nem concordo" e somando as respostas de concordância (“concordo em parte” + "concordo totalmente”) e discordâncias (“discordo em parte” + “discordo totalmente”).

A tabulação segue a ordem decrescente a partir dos índices de concordância, iniciando pelo questionário dos estudantes.

\section{Aos alunos:}

\begin{tabular}{|l|c|c|}
\hline \multicolumn{2}{|c|}{ Ao me envolver com a criação e produção de programas de rádio, na escola: } \\
\hline Expectativa educomucativa & $\begin{array}{c}\text { Discordo } \\
\text { totalmente } \\
+ \\
\text { Discordo em } \\
\text { parte }\end{array}$ & $\begin{array}{c}\text { Concordo } \\
\text { em parte } \\
+ \\
\text { Concordo } \\
\text { totalmente }\end{array}$ \\
\hline $\begin{array}{l}\text { Consigo aprender e me divertir ao mesmo tempo quando faço os } \\
\text { programas. }\end{array}$ & $100 \%$ \\
\hline $\begin{array}{l}\text { Aprendi a trabalhar melhor em grupo, cooperando com meus amigos e } \\
\text { colegas. }\end{array}$ & $2,5 \%$ & $95 \%$ \\
\hline $\begin{array}{l}\text { Preocupo-me em pesquisar os assuntos e temas que serão abordados nos } \\
\text { programas. }\end{array}$ & $2,5 \%$ & $95 \%$ \\
\hline $\begin{array}{l}\text { Fiquei mais preparado para fazer leitura crítica dos meios de } \\
\text { comunicação. Tenho mais noção de como se fazem programas e como se } \\
\text { escolhem os temas. }\end{array}$ & - & $92,5 \%$ \\
\hline Tenho desenvolvido mais minha criatividade. & - & $92,5 \%$ \\
\hline $\begin{array}{l}\text { Percebo que estou mais preparado para saber selecionar e organizar } \\
\text { informações. }\end{array}$ & $2,5 \%$ & $92,5 \%$ \\
\hline $\begin{array}{l}\text { Estou me sentindo menos tímido e mais solto para falar em público e } \\
\text { dialogar com as pessoas. }\end{array}$ & $2,5 \%$ & $92,5 \%$ \\
\hline Melhorei minha capacidade de questionar, criticar e argumentar. & $5 \%$ & $90 \%$ \\
\hline Percebo que fiquei mais responsável. & $5 \%$ & $87,5 \%$ \\
\hline $\begin{array}{l}\text { Sinto-me mais feliz e motivado ao saber que outras pessoas estão ouvindo } \\
\text { o programa em que aparece minha voz ou que eu ajudei a fazer. }\end{array}$ & $2,5 \%$ & $82,5 \%$ \\
\hline $\begin{array}{l}\text { Percebo que os professores que se envolvem com a rádio me respeitam } \\
\text { mais e dão espaço para eu expressar minhas idéias. }\end{array}$ & $10 \%$ & $82,5 \%$ \\
\hline Estou mais atento e disciplinado. & $2,5 \%$ & $80 \%$ \\
\hline $\begin{array}{l}\text { Estou mais consciente sobre o que acontece na escola e na comunidade ao } \\
\text { redor dela, tenho mais contato com a comunidade. }\end{array}$ & $10 \%$ & $77,5 \%$ \\
\hline Percebo que melhorou minha relação com os professores e funcionários. & & \\
\hline
\end{tabular}


$\underline{\text { Aos professores e funcionários: }}$

\begin{tabular}{|l|c|c|}
\hline \multicolumn{2}{|c|}{ Observando e convivendo com crianças e jovens que criam e produzem programas de rádio } \\
na escola percebo que:
\end{tabular}

\section{3 - Análise dos questionários}

Iniciamos a análise dos resultados dos questionários com a constatação de que houve um elevado grau de concordância com as afirmações relativas aos benefícios que o 
educando obtém ao se envolver com as práticas educomunicativas de produção radiofônica em sua escola. A aplicação dos questionários comprova que as várias hipóteses levantadas pela instância teórica da Educomunicação podem ser verificadas, na prática, por meio de atividades e de projetos decorrentes do “educom.rádio”, que foram adaptados às condições e às necessidades de cada unidade escolar.

Podemos afirmar que todas as vantagens elencadas pela teoria educomunicativa foram corroboradas pela avaliação de professores e estudantes no que diz respeito ao desenvolvimento do educando e às relações de comunicação na escola. Os maiores índices de discordância atingiram apenas 10\% entre os alunos (em relação ao fato de estarem mais atentos e disciplinados e também à melhoria da relação com os professores) e somente $13,3 \%$ entre os professores (que discordaram de que os alunos ficaram mais preparados para fazer uma leitura crítica dos meios de massa). Aliás, é importante ressaltar que entre o grupo de 15 professores, coordenadores e funcionários das escolas pesquisadas, esta foi a única das catorze hipóteses em que houve algum índice de discordância.

Ao cruzarmos os dados de todos os questionários podemos evidenciar o alto índice de concordância e o ínfimo percentual de discordância em relação às afirmações.

\begin{tabular}{|c|c|c|}
\hline Concordância (concordo em parte + concordo totalmente) & 717 & $93,1 \%$ \\
\hline Nem concordo, nem discordo & 43 & $5,6 \%$ \\
\hline Discordância (discordo em parte + discordo totalmente) & 10 & $1,3 \%$ \\
\hline Totais & 770 & $100 \%$ \\
\hline
\end{tabular}

É importante ressaltar que do nosso universo de 770 respostas (14 perguntas para cada um dos 55 questionários respondidos) registramos 717 concordâncias, ou seja, 93,1\% do total. Já o índice geral de discordância em relação às hipóteses aventadas foi de apenas $1,3 \%$. 
Além de constatar que tanto os alunos como os docentes reconheceram vários benefícios práticos para o desenvolvimento do educando, o uso da "escala Likert” e a tabulação dos dados nos permitem identificar quais as mudanças mais significativas que nossos entrevistados observam desenvolvendo a prática radiofônica na escola. É possível notar que, em alguns casos, há divergências entre as opiniões dos docentes e as dos estudantes em relação aos principais benefícios constatados.

A opção pela escala Likert se mostrou fundamental também para identificarmos diferentes impactos nas mudanças no comportamento do educando, dentro dos níveis de concordância apontados. Percebemos que entre os estudantes, o índice de "concordo totalmente” varia de $42,5 \%$ a $95 \%$ e, entre os docentes, oscila de 13,3\% a 86,6\%, evidenciando que, apesar de concordarem com as hipóteses propostas, alunos e professores identificam nelas diferentes graus de impacto no comportamento e desenvolvimento do educando.

Analisando as respostas dos questionários constatamos que a relação aprendizado/diversão ("consigo aprender e me divertir ao mesmo tempo quando faço os programas”) foi a única afirmação que teve 100\% de concordância tanto entre os estudantes como entre os professores, evidenciando, assim, que as pessoas entrevistadas identificaram, de forma igual, tanto a formação e o desenvolvimento do educando, quanto um forte aspecto lúdico na produção radiofônica das escolas.

As respostas dos estudantes apontam que a diversão proporcionada pela realização de programas de rádio está mais relacionada ao prazer da concepção e produção do que necessariamente à emoção da veiculação e repercussão das produções. Chegamos a esta constatação ao notar que apesar de todos os alunos concordarem que aprendem e se divertem ao mesmo tempo, apenas $87,5 \%$ concordaram que "se sentem mais felizes e 
motivados ao saber que outras pessoas estão ouvindo o programa que ajudaram a fazer ou em que aparece sua voz”. Este índice cai para 70\% entre os estudantes que “concordam totalmente” com a afirmação, contra 95\% de concordância total em relação à afirmação de que aprendem e se divertem enquanto fazem programas de rádio.

Entre as afirmações avaliadas pelos entrevistados, destacam-se, além do “aprender e se divertir ao mesmo tempo”, outras duas que também não registraram nenhuma discordância (nem parcial nem total) nos 55 questionários respondidos por alunos e professores: “estou mais preparado para saber selecionar e organizar informações” e “tenho desenvolvido mais minha criatividade”. Ambos os benefícios dizem respeito ao desenvolvimento do educando propiciado por atividades práticas de produção radiofônica: a primeira mais relacionada à etapa de definição de pauta, pesquisa de fontes, dados, notícias ou informações e, a segunda, ligada principalmente às etapas de roteirização e produção, ao “como” abordar os temas e assuntos escolhidos.

No entanto, apesar da concordância em relação ao fato de que os alunos estão "mais preparados para selecionar e organizar informações”, parte dos professores entende que o desenvolvimento dessa habilidade não se reflete na mesma proporção para o aprimoramento da capacidade de "leitura crítica dos meios de comunicação”. Somente 60\% dos docentes afirmaram “concordar totalmente” que os alunos estão mais preparados nesse sentido, e 13,3\%, como já dissemos, chegaram a discordar em parte da afirmação. As entrevistas abertas com professores e coordenadores ajudam a entender o porquê desses índices: alguns docentes avaliam que apesar de conhecerem melhor os processos de realização de produtos e programas audiovisuais, muitos estudantes não mudaram significativamente seus hábitos de consumo enquanto telespectadores e ouvintes. 
Em relação às habilidades que dizem respeito à melhoria da capacidade expressiva dos estudantes, verificamos elevados graus de concordância (entre 92,5\% e 100\%) na opinião dos alunos e dos professores quando somamos as respostas "concordo em parte" e “concordo totalmente”. Ao analisarmos apenas os índices dos pesquisados que “concordaram totalmente”, constamos, definitivamente, que a realização das práticas radiofônicas auxiliou o educando a aprimorar:

- a criatividade (82,5\% na opinião dos alunos e 73,3\% na avaliação dos docentes);

- a capacidade de questionar, criticar e argumentar (67,5\% na opinião dos alunos e 80\% na avaliação dos docentes);

- a habilidade de trabalhar melhor em grupo (75\% na opinião dos alunos e 86,6\% na avaliação dos docentes);

- a oralidade, perdendo a timidez, tendo maior facilidade para dialogar e falar em público (72,5\% na opinião dos alunos e 73,3\% na avaliação dos docentes).

O "educom" é isso, ele ajuda o aluno por esse lado, ele desinibe, ele tira toda a vergonha do aluno, incentiva a leitura, incentiva a participação em atividades escolares, incentiva em comportamento, em ser exemplo, em não ser o famoso bagunceiro, visitante da secretaria ${ }^{173}$.

(Luiz Fernando Alves, EMEF Carlos Pasquale, oficineiro de rádio, 17 anos)

Eu não tenho mais vergonha. O professor pede para ler alguma coisa, eu estou sempre lendo, estou muito comunicativa; todo mundo fala isso na escola e eu acho que é graças ao "educom" que eu sou assim. ${ }^{174}$

\footnotetext{
173 - Depoimento disponibilizado na faixa 41 do CD que acompanha esta dissertação.

174 - Depoimento disponibilizado na faixa 42 do CD que acompanha esta dissertação.
} 
(Monise Sanches, EMEF Euclides de O. Figueiredo, ex-aluna, 15 anos)

Muitos alunos têm vergonha. Essa questão da rádio e da Educomunicação transforma muito eles, deixando-os mais capacitados para fazer qualquer tipo de coisa, qualquer tipo de trabalho, tanto dentro como fora da escola. ${ }^{175}$ (Jade Rodrigues, EMEF Euclides de O. Figueiredo, 8ª série, 14 anos)

O educom é multidisciplinar, mas o mais importante dele é o resgate social. Você não sabe o que é ver um aluno de 70 anos aprendendo a ler e a escrever com a posse de um microfone na mão, dando um recado que ele escreveu. Aquilo transforma o rosto dele, a alma dele. E depois, ele ouvir aquilo com todo mundo sentado lá: isso é uma conquista. ${ }^{176}$

Célia Sevilha (coordenadora pedagógica, EMEF Paulo Colombo Pereira)

No entanto, os índices de concordância total caem nas afirmações relacionadas ao comportamento dos estudantes tanto na opinião deles próprios como, principalmente, na de seus professores e coordenadores no que diz respeito a:

- Ficar mais responsável (70\% na opinião dos alunos e 53,3\% na avaliação dos docentes);

- Estar mais atento e disciplinado (62,5\% na opinião dos alunos e 13,3\% na avaliação dos docentes).

Apesar de não podermos associar a todos os alunos que se envolveram com as produções radiofônicas uma mudança de comportamento positiva em relação à

\footnotetext{
175 - Depoimento disponibilizado na faixa 43 do CD que acompanha esta dissertação.

176 - Depoimento disponibilizado na faixa 44 do CD que acompanha esta dissertação.
} 
responsabilidade, à atenção e à disciplina, é importante destacar que muitos estudantes entendem que as participações nos projetos de rádio colaboraram significativamente para que mudassem de postura e atitude:

Até antes da minha participação nesse projeto, eu era uma aluno bagunceiro, um aluno inquieto, um aluno que dava problema para a escola toda; eu vivia na diretoria, para assinar advertências. Depois que eu comecei a participar desse projeto, me despertou o interesse na participação nas aulas, na participação voluntária, na participação em atividades extracurriculares na escola ${ }^{177}$.

(Luiz Fernando Alves, EMEF Carlos Pasquale, ex-aluno e oficineiro de rádio, 17 anos)

A gente sentiu a mudança das responsabilidades, a gente tem que cumprir horários. A gente tem que escrever mais, ler mais, ficar interativo, ficar sabendo de tudo que vai ocorrer na escola e fora da escola. Melhorou muito para $_{\text {mim. }}{ }^{178}$

(Antônio Gustavo, EMEF Euclides de O. Figueiredo, 14 anos, $8^{\text {a }}$ série)

Outro aspecto que apesar de bem avaliado não atingiu altos índices de "concordo totalmente” diz respeito à relação professor-aluno. Apenas 42,5\% dos estudantes e 46,6\% dos docentes responderam concordar totalmente com a afirmação de que o envolvimento com a prática radiofônica melhorou a relação entre alunos e professores. No caso dos estudantes, $10 \%$ chegaram a discordar da afirmação e 12,5\% nem concordaram nem

\footnotetext{
177 - Depoimento disponibilizado na faixa 45 do CD que acompanha esta dissertação.

178 - Depoimento disponibilizado na faixa 46 do CD que acompanha esta dissertação.
} 
discordaram. A relação professor-aluno tem sido alvo de muitas críticas em diversas escolas públicas, o que era possível diagnosticar desde a época de capacitação presencial do "educom.rádio". A falta de harmonia, integração e, até mesmo, de respeito entre essas duas instâncias da escola era apontada, muitas vezes, como o maior obstáculo para a melhoria da gestão da comunicação no espaço escolar e para a consolidação de um ecossistema comunicativo aberto, franco e democrático. No entanto, as respostas de uma outra afirmação feita no questionário confirmam que as produções radiofônicas podem contribuir para relações mais harmônicas e horizontais entre docentes e estudantes.

\begin{tabular}{|l|c|}
\hline \multicolumn{1}{|c|}{ Respostas dos alunos } & $\begin{array}{c}\text { Concordo } \\
\text { totalmente }\end{array}$ \\
\hline $\begin{array}{l}\text { Percebo que os professores que se envolvem com a rádio me } \\
\text { respeitam mais e dão espaço para eu expressar minhas idéias. }\end{array}$ & $65 \%$ \\
\hline $\begin{array}{l}\text { Percebo que melhorou minha relação com os professores e } \\
\text { funcionários. }\end{array}$ & $42,5 \%$ \\
\hline
\end{tabular}

\begin{tabular}{|l|c|}
\hline \multicolumn{1}{|c|}{ Respostas dos professores/coordenadores } & $\begin{array}{c}\text { Concordo } \\
\text { totalmente }\end{array}$ \\
\hline $\begin{array}{l}\text { Os professores que se envolvem com a rádio respeitam mais os } \\
\text { alunos e dão espaço para eles expressarem suas idéias. }\end{array}$ & $80 \%$ \\
\hline Melhorou a relação dos alunos com os professores e funcionários. & $46,6 \%$ \\
\hline
\end{tabular}

Verificamos que $65 \%$ dos alunos e $80 \%$ dos professores disseram "concordar totalmente” com a afirmação de que “os professores que se envolvem com a rádio respeitam mais os alunos, dando espaço para eles expressarem suas idéias”. Dos 55 questionários respondidos, apenas um aluno “discordou em parte” da afirmação. Cruzando as respostas das duas afirmações, constamos que, tanto na opinião dos estudantes como na avaliação dos docentes, a relação professor-aluno é mais eficaz entre os docentes que se envolvem com as práticas radiofônicas. Os índices de “concordo totalmente” inferior a 50\% das respostas refletem os problemas de resistências e oposição aos projetos de rádio 
de parte dos professores, como pudemos identificar no capítulo anterior por meio das entrevistas.

Como foi dito no capítulo II, é importante retomar o conceito de "Educomunicação possível”, pois sabemos das dificuldades de atingir e envolver 100\% da comunidade escolar em torno de uma nova teoria e, principalmente, de novas práticas. De acordo com alguns depoimentos das entrevistas abertas dos estudos de caso, alunos e professores afirmaram terem vivido situações de conflito ou de oposição por parte de docentes que não se envolviam com as produções radiofônicas como: não liberar os alunos alguns minutos antes do intervalo para preparem o estúdio e iniciarem as transmissões; reclamar da presença de estudantes na escola fora de seu horário de aula; questionar o retorno de exalunos para a escola por integrarem a equipe da rádio; implicar com o volume das caixas acústicas; desmerecer e criticar o trabalho de outros professores que substituíam algumas atividades de sua disciplina como provas ou seminários por programas de rádio; etc.

A rádio ajuda a expressar a idéia do adolescente, porque tem muito professor que não gosta de ter a idéia do adolescente; porque o adolescente tem a idéia dele e a rádio faz com que a gente se sinta melhor em público para demonstrar nossas idéias para todos ${ }^{179}$.

(Glauco Roberto Gomes, EMEF Prof. Carlos Pasquale, 14 anos, 8ª série)

É importante ressaltar, porém, que muitos depoimentos de estudantes e professores que se envolvem com as práticas educomunicativas de produção radiofônica comprovam as afirmações sobre a maior abertura dos docentes à capacidade expressiva de seus alunos:

O adolescente pode se expressar, mostrar suas idéias e se sentir mais à vontade em público. Eu aprendi a fazer redação, minha convivência com o

179 - Depoimento disponibilizado na faixa 47 do CD que acompanha esta dissertação. 
público é melhor, com os professores e com os funcionários. A partir do momento que você tem um tempo na rádio para mostrar suas idéias e os professores começam a ver que suas idéias são boas, eles passam a te respeitar, não é mais aquele aluno, mas o jovem protagonista ${ }^{180}$.

(Glauco Roberto Gomes, EMEF Prof. Carlos Pasquale, 14 anos, 8ª série)

E não foi a mesma coisa depois desse dia, dessa rádio. Os alunos começaram a colocar suas idéias em sala de aula, os professores pararam para ouvir, para discutir. Isso acho que foi um grande prêmio para a gente, nossa grande evolução. ${ }^{181}$

(Antônio Gustavo, EMEF Euclides de O. Figueiredo, 14 anos, 8ª série)

À tarde ele é um horror e à noite os professores dizem "oi, tudo bem?", “como vai?”. Porque ele é o "moço da rádio” e aí a conversa é outra. Aí ele é importante: ele conversa com o professor de igual para igual. Ele vira outra pessoa. ${ }^{182}$

Célia Sevilha (coordenadora pedagógica, EMEF Paulo Colombo Pereira)

Se a relação professor-aluno ainda pode ser melhor trabalhada em âmbito escolar, outro aspecto positivo a se destacar é a maior conscientização dos estudantes em relação ao entorno da escola. Constatamos que $62,5 \%$ dos alunos e $86,6 \%$ dos docentes afirmaram “concordar totalmente” com a assertiva de que "os estudantes ficaram mais conscientes sobre o que acontece na escola e na comunidade ao redor dela, tendo mais contato com a

\footnotetext{
180 - Depoimento disponibilizado na faixa 48 do CD que acompanha esta dissertação.

181 - Depoimento disponibilizado na faixa 49 do CD que acompanha esta dissertação.

182 - Depoimento disponibilizado na faixa 50 do CD que acompanha esta dissertação.
} 
comunidade”. O fascínio propiciado pelo envolvimento com a produção radiofônica tem gerado, espontaneamente, muita divulgação “boca-a-boca” sobre a rádio da escola:

Eu tenho aqui aluno que vê o irmão mais velho participar da rádio e quer participar também, ou o primo, o vizinho, o colega de classe, assim vai, eles vão incentivando um ao outro... às vezes fica complicado até arrumar vaga porque é bem procurado ${ }^{183}$.

(Érika Brasil, EMEF Carlos Pasquale, oficineira de rádio)

A participação de membros da comunidade e sua integração com os alunos das equipes das rádios escolares também se reflete, muitas vezes, no conteúdo dos programas.

Como é uma rádio local, o pessoal de fora pode vir e dar a opinião dele também. Então, você tem que ficar aberto para escutar a opinião do próximo e colocar também na rádio. E, com certeza, em uma rádio privada FM normal, dessas que a gente escuta, é diferente, eles passam o que está na mão deles, eles acabam monopolizando na mão deles ${ }^{184}$.

(Laila El Alam, 16 anos, ex-aluna da EMEF Carlos Pasquale)

A aplicação dos questionários se mostrou extremamente útil para identificarmos "se” e “quanto” os benefícios propostos pela teoria educomunicativa foram percebidos, na prática, por alunos e professores de algumas escolas da rede pública de Ensino Fundamental de São Paulo que deram continuidade às ações do projeto “educom.rádio”, desenvolvendo produções radiofônicas e chegando, até mesmo, a criar uma emissora escolar. Constatamos que a avaliação foi positiva tendo em vista que a grande maioria dos estudantes e dos professores pesquisados concordou (“em parte” ou “totalmente”) com todas as afirmações

\footnotetext{
183 - Depoimento disponibilizado na faixa 51 do CD que acompanha esta dissertação.
}

184 - Depoimento disponibilizado na faixa 52 do CD que acompanha esta dissertação. 
propostas. O índice mais baixo de concordância registrado foi de 77,5\% (entre os estudantes em relação à melhoria da relação com os professores e funcionários) e de 86,6\% (entre os professores a respeito do melhor preparo dos alunos para a leitura crítica dos meios de massa). Das 28 afirmações propostas (14 no questionário dos alunos e 14 no dos professores), 22 tiveram concordância igual ou superior a 90\%. Os índices de concordância foram tão elevados que tivemos que recorrer à divisão proporcionada pelo uso da escala Likert (“concordo em parte” e “concordo totalmente”) para poder avaliar melhor quais os benefícios que tiveram maior impacto na percepção de estudantes e professores.

Os questionários, assim como muitos depoimentos das entrevistas abertas realizadas nas quatro escolas, comprovam nossa hipótese principal de que projetos educomunicativos contribuem para a melhoria da capacidade expressiva e da competência comunicativa dos sujeitos educandos, neste caso, crianças e jovens estudantes de escolas públicas. Além disso, foi possível constatar a alta percepção da comunidade escolar em relação ao aspecto lúdico proporcionado pelo uso do rádio e sua ligação com aprendizagem, trazendo a noção de que "entreter” não precisa estar dissociado de “educar” e que por meio da realização de produções radiofônicas é possível aprender e se divertir.

Outro ponto que pudemos detectar pela aplicação e análise dos questionários refere-se ao fato de que nem todos os estudantes que aprimoram a capacidade expressiva necessariamente apresentam melhor comportamento ou mostram-se mais responsáveis, atentos e disciplinados. Também constamos que um dos objetivos mais difíceis de ser atingido pelas práticas educomunicativas no espaço escolar diz respeito à melhoria da relação professor-aluno, principalmente com os docentes que não se envolvem com as tecnologias de comunicação na escola. No entanto, a riqueza e variedade das práticas diagnosticadas nessas quatro escolas, bem como o elevado grau de concordância de alunos 
e docentes em relação aos benefícios propiciados aos estudantes pela prática radiofônica educomunicativa, comprovam que se trata de uma alternativa viável e eficaz para melhorar as relações de comunicação em âmbito escolar, envolver a comunidade, desenvolver a capacidade expressiva de crianças e jovens, fomentando o protagonismo infanto-juvenil. 


\section{Capítulo 8}

\section{A produção radiofônica nas escolas de São Paulo: a visão do poder público municipal}

As visitas realizadas durante nossa pesquisa às quatro escolas que realizam produções radiofônicas nos fornecem um rico material para análise qualitativa, porém percebemos a necessidade de oferecer também um panorama geral sobre a continuidade do “educom.rádio” na rede municipal de ensino de São Paulo. Nesse sentido, entendemos que seria de grande importância entrevistar um dos coordenadores do projeto "Educom nas ondas do rádio” na Secretaria Municipal de Educação da Prefeitura de São Paulo, o professor Carlos Alberto Mendes de Lima ${ }^{185}$, que também é presidente do Comitê Gestor da Lei Educom. Em 2006, Mendes visitou 208 escolas que participaram do projeto “educom.rádio”.

Ele explica que estas visitas tinham dois objetivos principais: aprimorar o desenvolvimento do projeto nas escolas que realizavam produções radiofônicas e constatar, por outro lado, porque algumas escolas que haviam recebido o kit de rádio não o estavam utilizando.

As visitas tinham também um caráter técnico que incluía a regulagem de equipamentos, a instalação ou manutenção de antenas e caixas acústicas, além de orientações para a criação ou adaptação de estúdios de rádio nas escolas. Nas visitas, Mendes buscou abrir um canal de comunicação entre as unidades escolares e a Secretaria Municipal de Educação

\footnotetext{
185 - Carlos Alberto Mendes de Lima divide a coordenação do projeto “Educom nas ondas do rádio” com o professor Jarbas Mazzariello.
} 
bem como oferecer breves cursos, atividades e capacitações relacionados à produção radiofônica.

Sobre os programas de rádio realizados nas escolas, Mendes chegou às seguintes constatações:

- A participação de crianças e jovens é muito maior do que a de professores;

- Poucos docentes tomaram a iniciativa de estimular a realização de programas vinculados às suas disciplinas;

- Uma das principais dificuldades apontadas para a continuidade do projeto é a saída de muitos alunos que participaram do período de capacitação, seja por motivo de mudança de escola ou por conclusão do Ensino Fundamental;

- Na programação das escolas predominam música e informação;

- A maioria dos programas é veiculada nos horários de intervalo;

- Poucas produções são exibidas em sala de aula.

Mendes justifica porque, na sua avaliação, as atividades de produção radiofônica são conduzidas mais pelos alunos do que pelos docentes:

Acabou ficando mais na mão do aluno porque ainda não ficou claro para o professor que a proposta é também uma proposta pedagógica. Ela é vista pelos professores mais como uma proposta de protagonismo. Normalmente quem toca o projeto nas escolas é o grêmio e aí tem um professor que lidera aquele grupo $^{186}$.

186 - Depoimento disponibilizado na faixa 53 do CD que acompanha esta dissertação. 
Nesse sentido, Mendes esclarece que ainda não há muitas produções de rádio relacionadas às disciplinas curriculares e que predominam, entre os programas radiofônicos, aqueles planejados, gravados e transmitidos fora da sala de aula:

O que a gente vê, no geral, nas escola, é um trabalho extra-classe. Ele é feito, na maioria das vezes, no horário do intervalo, em que o aluno coloca música e informação e que, normalmente, é o aluno que vai buscar no professor a fonte de inspiração para poder colocar as suas informações. ${ }^{187}$

Diante deste predomínio dos estudantes no exercício da prática radiofônica escolar, Mendes afirma ter detectado, durante as visitas, outra competência que pode ser desenvolvida por meio da oralidade radiofônica: o aprimoramento da leitura e, conseqüentemente, da escrita:

A produção de rádio ativa uma habilidade que é pouco usada na sala de aula que é a habilidade oral. ... Participando do processo de produção de rádio, trabalhando minha parte oral, necessariamente eu vou ter que pegar um texto para ler, então eu ativo outro habilidade: a da leitura. E aí eu vou aprender a escrever melhor. ${ }^{188}$

Outro aspecto importante destacado por Mendes diz respeito às dificuldades que as escolas encontravam quando havia algum dano ou falha nos equipamentos. O Comitê Gestor da Lei Educom promoveu mudanças técnicas incluindo a alteração da concepção tecnológica do kit de rádio, pois as escolas, as Coordenadorias de Educação e a Prefeitura estavam dependentes de um único fornecedor, o que inviabilizava a concorrência por um valor menor nos custos de manutenção dos equipamentos.

\footnotetext{
187 - Depoimento disponibilizado na faixa 54 do CD que acompanha esta dissertação.

188 - Depoimento disponibilizado na faixa 55 do CD que acompanha esta dissertação.
} 
Mendes ressalta ainda que defende a integração do projeto de rádio com o setor de “Informática Educativa”, a fim de promover a utilização de softwares de edição gratuitos (como o Audacity) e a criação de uma webrádio e/ou de um podcast, compartilhados pela rede municipal de ensino, que veiculariam e disponibilizariam programas de diferentes escolas. Mendes acredita que o uso do computador na realização dos programas de rádio poderá melhor qualidade das produções, aumentar o alcance e o número de ouvintes das produções, além de facilitar a troca de arquivos de áudio entre as escolas.

A webrádio e o podcast também seriam, segundo Mendes, alternativas às dificuldades encontradas para tentar veicular os programas além dos muros das escolas. A questão ganhou mais importância depois da constatação de que não há, numa cidade com 11 milhões de habitantes, emissoras comunitárias com permissão legal para atuarem. Tal situação foi agravada em 2006, quando uma ação da Polícia Federal e da Anatel (Agência Nacional de Telecomunicações) resultou no fechamento da Rádio Heliópolis, que funcionava há 14 anos na maior favela de São Paulo.

A ação ocorreu um ano após o ex-prefeito de São Paulo, José Serra, ter sancionado a lei $\mathrm{n}^{0}$ 14.013, que permite a exploração do serviço de radiodifusão comunitária (RADCOM) no município liberando a venda de espaço publicitário sob a forma de patrocínio. A lei resulta de projeto que tramitou por quatro anos na Câmara Municipal. Na data da assinatura, segundo o Sistema de Controle de Radiodifusão da Agência Nacional de Telecomunicações, das 47 emissoras de rádio existentes em São Paulo havia 17 com licença para atuar em FM, 14 para AM, 16 para ondas curtas e nenhuma para rádio comunitária $^{189}$.

\footnotetext{
189 - Dados pesquisados no site do Fórum Nacional pela Democratização da Comunicação, disponível em www.fndc.org.br/arquivos/e-Forum52.doc. Acessado em 19/12/2006.
} 
Para Mendes, “a idéia da Educomunicação tem que perpassar essa idéia de só estar dentro da escola; tem que ser feita como uma política pública de comunicação”. O professor adverte, ainda, que a população não é devidamente informada sobre o que acontece nos órgãos públicos e acredita que o conceito e as práticas do "educom.rádio" poderiam ser usados nesse sentido para "ampliar o canal de comunicação entre o poder público e a sociedade”.

Mendes esclarece que o Comitê Gestor da Lei Educom busca envolver efetivamente cinco secretarias da própria Prefeitura e conta com representantes dos grêmios estudantis e dos professores da rede municipal de ensino, do Sindicato dos Radialistas de São Paulo, Sindicato dos Jornalistas São Paulo e de universidades. Explica que "esse grupo pensa a educomunicação como política pública” buscando aprimorar o trabalho intersecretarial com o objetivo de "melhorar a comunicação na cidade”. 


\title{
Capítulo 9
}

\section{Conclusões e considerações finais}

\begin{abstract}
Quem se preocupa em produzir comunicação democrática e participativa e em promover a ação comunicativa, por onde quer que ande, revela que entendeu que o problema das comunicações - sobretudo nos dias de hoje não se reduz às tecnologias de ponta e não diz respeito apenas aos governantes ou aos empresários do setor. Na verdade, produzir comunicação tem se revelado a melhor forma de celebrar em plenitude o exercício da cidadania ${ }^{190}$. (Ismar de Oliveira Soares)
\end{abstract}

\section{1 - As rádios escolares: semelhanças e diferenças}

As visitas às escolas que deram continuidade às práticas educomunicativas apontaram para a existência de muitas similaridades em relação aos projetos radiofônicos desenvolvidos em cada uma das quatro unidades escolares da Prefeitura de São Paulo. Apesar de cada EMEF ter adaptado os processos de realização e transmissão às suas necessidades e particularidades, concluímos que há mais semelhanças do que diferenças entre elas. Constatamos nas quatro escolas pesquisadas as seguintes práticas em comum:

- A associação de conceitos como "Educomunicação”, “educom” e “educomunicador” às práticas desenvolvidas: estes termos são recorrentes nas falas

\footnotetext{
190 - Ismar de Oliveira SOARES. Sociedade da informação ou da comunicação. São Paulo. Cidade Nova, 1997 p.71
} 
de alunos e professores, nos conteúdos de materiais sonoros produzidos e até mesmo na denominação de membros da equipe, como os "educomunicadores mirins” da EMEF Professor Carlos Pasquale e o perfil de “educomunicador” que a equipe da "Rede Interferência”, da EMEF Euclides de Oliveira Figueiredo, procura identificar nos alunos.

- A discussão a respeito de subjetividade e de diversidade cultural (dois conceitos transversais trabalhados durante a capacitação presencial do “educom.rádio”) nos conflitos gerados a partir da veiculação de músicas pelas rádios escolares: todas as escolas pesquisadas apontaram algum tipo de dificuldade em relação à definição de estilos e gêneros musicais. Aproveitaram os conflitos para ampliar o leque de consulta à comunidade educativa, aplicar pesquisas com seu público-alvo e buscar oferecer uma grade musical variada, estimulando o respeito aos diferentes gostos, bem como a discussão sobre a mensagem transmitida pelas músicas selecionadas.

- A compreensão da idéia de que a rádio escolar tem potencial para ser muito mais do que um simples aparelho de som para veiculação de músicas: todas as escolas pesquisadas procuram realizar e transmitir programas com diferentes gêneros e linhas temáticas. Algumas unidades escolares procuram relacionar a música do programa com o tema abordado, como ocorre nos programas diários da EMEF Professor Carlos Pasquale, no quadro “MPB Compositor” da EMEF Euclides de Oliveira Figueiredo e nos programas especiais de datas comemorativas da EMEF José Bonifácio.

- A necessidade de envolver o maior número possível de membros das diversas instâncias da comunidade escolar incluindo, além da direção, também professores e funcionários: as equipes das rádios escolares tiveram que aprender empiricamente a 
conciliar o desenvolvimento das atividades radiofônicas com as demais ações da escola. Durante a capacitação presencial do "educom.rádio”, a maioria das escolas participantes estava fora de seu território (indo a uma escola-pólo) e todos os seus cursistas haviam disponibilizado o sábado apenas para o projeto. Já no dia-a-dia das escolas, professores e alunos que quiseram dar continuidade às práticas de produção radiofônica começaram a perceber que o projeto poderia alterar a rotina escolar de forma muito mais intensa do que as tradicionais aulas dentro das salas.

- A abertura a todos os integrantes da comunidade educativa que tenham interesse de participar dos projetos de rádio: apesar de algumas escolas deixarem a operação dos equipamentos restrita a um grupo de alunos, as equipes de rádio pesquisadas mostraram-se abertas e receptivas à inclusão de novos integrantes, responsabilizando-se pelas capacitações e orientações necessárias. O número de pessoas envolvidas com as produções radiofônicas evidencia a eficácia do processo de multiplicação realizado nessas escolas, pois todas possuem mais de 10 estudantes (número máximo de alunos inscritos por escola no “educom.rádio”) vinculados diretamente às suas rádios: de 16 alunos na EMEF Paulo Colombo Pereira de Queiroz a 60 estudantes na EMEF Professor Carlos Pasquale.

- A constatação da necessidade de se deslocar ao menos uma pessoa que pudesse se dedicar quase exclusivamente aos projetos da rádio, fazendo a mediação entre as diversas instâncias em diferentes períodos: todas as escolas chegaram à conclusão de que a rádio não manteria produções e transmissões de forma consistente se cada professor a utilizasse da forma que quisesse, no horário que pudesse. Cada escola pesquisada encontrou uma solução diferente para designar profissionais que se responsabilizassem pelos projetos da rádio e de outros meios de comunicação: 
oficineiros na EMEF Professor Carlos Pasquale; professores e auxiliar de sala de leitura na EMEF Euclides de Oliveira Figueiredo, uma coordenadora pedagógica e um secretário na EMEF Paulo Colombo Pereira de Queiroz; uma professora readaptada e uma professora de Educação Artística na EMEF José Bonifácio. Essa variedade de profissionais que assumiram a gestão das rádios (oficineiro, funcionário, professor readaptado, coordenador pedagógico) evidencia que a estrutura funcional das escolas não estava preparada para implementar um projeto de comunicação abrangente.

- A participação dos estudantes é mais efetiva do que a dos professores: todas as escolas, com diferentes intensidades, realizaram algumas produções radiofônicas que foram concebidas em sala de aula ou que partiram da iniciativa de um professor que não participa da gestão da rádio. No entanto, o fluxo inverso (do aluno que procura o professor) se mostrou mais comum nas quatro escolas pesquisadas. Além disso, em todas elas, há mais produções realizadas somente por alunos do que produzidas conjuntamente por estudantes e professores.

- O maior envolvimento de alunos mais velhos nas equipes de rádio: em todas as escolas pesquisadas, a produção radiofônica é quase monopolizada por estudantes de $5^{\mathrm{a}}$ a $8^{\mathrm{a}}$ séries. No entanto, é importante ressaltar as atividades de algumas escolas em que os alunos mais experientes preocupam-se em atrair e orientar estudantes mais novos, como ocorre na EMEF Professor Carlos Pasquale (onde alunos da $5^{\text {a }}$ série capacitam estudantes da $2^{\mathrm{a}}$ série) e José Bonifácio (onde alunas da $5^{\mathrm{a}}$ série fazem programas especiais com temas infantis voltados ao público de $1^{\text {a a }} 4^{\text {a }}$ ).

- O predomínio de música e informação nos programas: apesar do baixo índice de programas musicais realizados durante a capacitação presencial do “educom.rádio”, 
identificamos que esse gênero cresceu muito entre as produções dos alunos nas escolas. No entanto, os estudantes também utilizam, muitas vezes, a música dentro de um contexto durante programas jornalísticos para ilustração de temas e também em programas de variedades. Constatamos que, apesar de algumas produções esporádicas de ficções e peças publicitárias radiofônicas, o gênero jornalístico continua predominante (assim como ocorreu nas diferentes fases do “educom.rádio”) quando analisamos os programas que não se resumem à mera veiculação de músicas nos horários de entrada e de intervalo. O número de produções humorísticas é quase inexpressivo. No entanto, os estudantes das quatro escolas garantem que sempre procuram acrescentar um pouco de humor e descontração nos programas informativos e nos de variedades. Os estudantes objetivam utilizar uma "linguagem jovem” nos programas fazendo, muitas vezes, uma mescla do caráter informativo das AMs com a agilidade e descontração das FMs.

- A definição de pautas diferentes das difundidas pelos meios de massa: os gêneros e formatos predominantes dos programas veiculados nas rádios escolares pesquisadas não se diferenciam muito daqueles produzidos nas emissoras comerciais. No entanto, quando analisamos os temas e os assuntos dos programas escolares diagnosticamos uma grande diferença em relação à pauta comercial. Essa mudança de conteúdos é evidenciada pela realização de programas vinculados a algumas disciplinas curriculares ou a temas transversais e, também, pela importância atribuída a assuntos que dizem respeito apenas à própria escola e à comunidade ao redor da unidade escolar. 
Apesar de tantas semelhanças entre as escolas pesquisadas, também podemos identificar algumas diferenças em relação ao processo de produção radiofônica:

- O maior ou menor grau de envolvimento do corpo docente com a rádio da escola oferece diferentes processos de concepção e realização de programas. Identificamos dois casos extremos. Um é o da EMEF Professor Carlos Pasquale, onde as pautas são definidas exclusivamente pelos estudantes que fazem sozinhos a programação, contando apenas com a mediação dos oficineiros. Por outro lado, tivemos acesso às experiências da EMEF Paulo Colombo Pereira de Queiroz, onde muitos programas são concebidos, roteirizados e ensaiados nas salas de aula com os professores. Nesta escola, assim como na EMEF José Bonifácio, a rádio passou, efetivamente, a fazer parte do Projeto Político-Pedagógico.

- Algumas escolas expandiram suas atividades de estímulo à capacidade expressiva dos estudantes para além do rádio, como a EMEF José Bonifácio que desenvolve, paralelamente aos programas radiofônicos, um jornal-mural mantido e atualizado pela mesma equipe da rádio. A compreensão de que as práticas educomunicativas não se resumem à linguagem radiofônica possibilitou que algumas escolas transformassem suas equipes de rádio em grupos multimídia. Destacamos os casos das EMEF Paulo Colombo Pereira de Queiroz e Euclides de Oliveira Figueiredo. Na primeira, a equipe da rádio desenvolve projeto com transmissão de filmes e também se responsabiliza por tudo que diga respeito a materiais midiáticos, equipamentos sonoros para aulas e atividades especiais, fitas de áudio e vídeo, reprodução de CDs, etc. Na segunda, a equipe da rádio avançou não só na área da Comunicação, mas também no espaço das Artes, desenvolvendo projetos com fanzines, graffiti, fotos e apresentações multimídias. 
Ironicamente, dentre as escolas pesquisadas, a única que não foi contemplada com a entrega dos equipamentos foi, justamente, a que mais expandiu as práticas comunicativas para além da linguagem radiofônica, formando uma verdadeira equipe de comunicação na escola. Trata-se da comprovação de que o desenvolvimento de projetos que estimulam a capacidade expressiva e o protagonismo infanto-juvenil dependem muito mais da vontade da comunidade escolar do que de aparelhos e equipamentos técnicos sofisticados.

As experiências dessas quatro escolas públicas de São Paulo, algumas localizadas em regiões carentes, são importantes não só para orientar as diretrizes de ensino do poder público, mas também para mostrar novas possibilidades às escolas particulares. Muitas vezes, infectadas pelo vírus do “marketing educativo”, elas adquirem sofisticados equipamentos tecnológicos sem propiciar aos seus alunos experiências tão diferenciadas de uso dos meios como as que pudemos presenciar, tendo dificuldades de superar a visão instrumental das tecnologias de informação e comunicação.

Os dados coletados por meio das entrevistas e dos questionários revelam o potencial pedagógico do rádio como instrumento de inclusão. Na opinião dos alunos e professores, a prática radiofônica propiciou o desenvolvimento da fala, o aprimoramento da leitura e da escrita, bem como uma relação de maior satisfação e motivação com novos processos de aprendizagem por parte do educando por meio do aspecto lúdico, como foi constatado por unanimidade nos questionários respondidos.

É importante destacar, como reconhece a educadora Santa Marli Pires dos Santos, que a ludicidade vem ganhando cada vez mais espaço entre as teorias da Educação e, nesse sentido, o uso da linguagem radiofônica pode contribuir significativamente. 
O desenvolvimento do aspecto lúdico facilita a aprendizagem, o desenvolvimento pessoal, social e cultural, colabora para uma boa saúde mental, prepara para um estado interior fértil, facilita os processos de socialização, comunicação, expressão e construção do conhecimento. ${ }^{191}$

\section{2 - Perspectivas para as ações educomunicativas}

A Prefeitura de São Paulo, logo após a mudança da gestão municipal que coincidiu com o fim da capacitação do "educom.rádio”, adotou, de início, uma visão instrumentalista, entendendo que a viabilização prática da Educomunicação nas escolas estaria vinculada ao equipamento de rádio. Desta forma, procurou avaliar somente as unidades escolares que receberam o Kit com os equipamentos, priorizando, em muitos casos, a contratação de oficineiros para transmissão de conceitos técnicos, em vez de educomunicadores que pudessem oferecer, além dos aspectos de técnicas e linguagens radiofônicas, uma visão mais abrangente sobre os processos comunicativos.

Dois anos após a nova gestão ter assumido a Secretaria de Educação sem ter dado continuidade à parceria com o NCE-USP para o acompanhamento das práticas educomunicativas nas escolas, constatamos uma situação paradoxal:

- Muitas escolas que não foram contempladas com a entrega do Kit de equipamentos gostariam de tê-lo recebido e de colocar em prática seu planejamento de rádio escolar;

\footnotetext{
191 - Santa Marli Pires dos SANTOS. O lúdico na formação do educador. Petrópolis: Vozes, RJ, 1997, p.12
} 
- Algumas escolas que receberam o Kit de equipamentos não implantaram sua rádio restrita e, muitas vezes, mantêm os equipamentos trancados, fora do alcance dos alunos.

Uma alternativa viável sugerida por membros das comunidades educativas - caso a decisão da administração pública de não adquirir equipamentos para as 200 escolas que ainda não os receberam permanecer irredutível - é a redistribuição do Kit de equipamentos, retirando-os das escolas em que não são utilizados para contemplar unidades escolares que apresentem um projeto de implantação de sua emissora de rádio.

A experiência das escolas pesquisadas mostra que é possível pensar a Educomunicação como política pública, transcendendo mudanças de gestões e de partidos políticos. O uso do rádio e de outras tecnologias de comunicação pode ser inserido no Projeto PolíticoPedagógico das escolas, superando o viés das oficinas performáticas (“aprender a mexer”), pautando-se pelo contexto da alfabetização múltipla, da escrita com novas linguagens e do desenvolvimento pessoal do aluno.

Acreditamos que esta pesquisa contribuiu para a análise da aplicação prática dos conceitos educomunicativos. O sucesso de muitas ações relatadas e a concordância dos membros das comunidades educativas a respeito do desenvolvimento do educando comprovam que é possível implementar, em âmbito escolar, projetos de mediação tecnológica que aprimorem a expressão comunicativa de crianças e jovens.

Ficou evidente, porém, que não se trata de um trabalho rápido e fácil de ser implementado porque:

- questiona a estrutura autoritária e hierarquizada da escola; 
- propõe que os docentes passem a se envolver com atividades e linguagens às quais que não estão acostumados;

- necessita do envolvimento de diferentes instâncias da comunidade escolar.

- precisa - levando em conta especialmente a novidade representada pela recente difusão das práticas educomunicativos - contar com algum tipo de assessoria externa ou de acompanhamento de especialistas, em condições de manter a coerência epistemológica dos projetos em desenvolvimento e de propiciar a formação de redes que fortaleçam as ações implementadas.

Cada projeto educomunicativo proposto, independentemente da(s) mídia(s) que venha(m) a ser trabalhada(s) na escola, deve prever, desde o início, a alta rotatividade de alunos, professores e funcionários preocupando-se não só com a formação, mas também com a multiplicação do número de pessoas envolvidas, evitando, desta forma, que sofra com a descontinuidade que caracteriza muitas ações implementadas pelo poder público.

Os estudos de caso desta pesquisa comprovam que projetos educomunicativos podem trazer muitos benefícios ao educando, à escola e à sua comunidade, apontando para a existência de um terreno fértil a ser semeado em muitas instituições educativas por profissionais que se orientem pela teoria do novo campo da Educomunicação. Constatamos que as escolas pesquisadas que desenvolveram projetos bem sucedidos não se pautaram pela instrumentalidade tecnológica, mas pela gestão participativa, pela abertura ao diálogo, pela busca da melhoria dos processos de comunicação e pelo estímulo à liberdade de expressão vinculada à responsabilidade e à ética.

O trabalho com novas linguagens, mídias e tecnologias no espaço escolar pode propiciar a descoberta e a lapidação de alunos com grande talento comunicativo. Além disso, pode 
possibilitar o encaminhamento profissional de jovens das classes mais baixas, que talvez nunca teriam acesso às novas tecnologias e formas de expressão se não fosse a oportunidade oferecida em âmbito escolar. Podemos possibilitar que o educando desenvolva suas habilidades em determinada função ou etapa do processo de realização de produtos audiovisuais, de acordo com a competência que descobriu que tem e quer aprimorar, a fim de obter uma vaga no mercado de trabalho que possa lhe proporcionar remuneração e satisfação pessoal.

Não podemos nos esquecer, ainda, que será possível preparar e atualizar os estudantes para o rápido processo de convergência de mídias. Trata-se da oportunidade de capacitar os educandos para novas funções no mercado de trabalho oriundas do avanço tecnológico em áreas relacionadas a entretenimento, design multimídia, telecomunicações, informática, cultura, artes e, até mesmo, Educomunicação.

As práticas radiofônicas não se restringem mais aos processos analógicos das fitas magnéticas e estão sendo aprimoradas pelo uso do computador, capaz de agilizar e otimizar a pesquisa da pauta, a elaboração do roteiro, a gravação e a edição, bem como a veiculação de programas ou a disponibilização de arquivos sonoros na Internet.

Sabemos que a presença e o uso das novas tecnologias na escola ainda provocam polêmicas alimentadas pelos embates entre apologias e preconceitos, como alerta o estudioso inglês David Buckingham.

Por um lado, o computador se converte em um cômodo bode expiatório, um objeto perverso sobre o qual devemos descarregar nossas culpas e nossas frustrações relativas à violência, à imoralidade, ao mercantilismo e à sexualidade, como o desaparecimento dos valores familiares. Assim mesmo, por outro lado, o computador pode servir de panacéia, o depositário de 
esperanças e sonhos, um agente mágico que libertará as sabedorias e as virtudes que antes permaneciam ocultas ${ }^{192}$.

Nesse sentido, os educadores do século XXI devem procurar evitar o que o argentino Jorge Huergo denomina de "tecnoutopia" quando se fala da presença da tecnologia no espaço escolar: parece que somente basta sua incorporação para que somente sua presença produza efeitos mágicos; o erro se encontra possivelmente em pensar que porque os meios tecnológicos estão ali todos têm que usá-los e de qualquer maneira ${ }^{193}$. As preocupações de Buckingham e Huergo ressaltam a importância da formação de profissionais capazes de atuarem como gestores e mediadores dos processos de comunicação nas escolas, propiciando uso adequado, planejado, integrado e constantemente avaliado das novas tecnologias. Nesse contexto, surge a necessidade de formar educomunicadores, pois, como reconhece Huergo quando falamos da relação tecnologias/educação, o problema não é de capacitação tecnológica, mas de transformação cultural ${ }^{194}$.

Esperamos que esta pesquisa tenha colaborado com as discussões sobre a importância da “mediação tecnológica na educação” a fim de proporcionar maior interação do educando com os elementos de seu contexto sócio-cultural, transcendendo a mera instrumentalidade tecnológica. Nesse sentido, é importante conscientizar os membros das instituições educativas para proporcionarem a “alfabetização múltipla” de que fala Orozco, permitindo que a escola passe do "palimpsesto” para o "hipertexto”, como defende Martín-Barbero, considerando o educando um sujeito ativo, comunicativo, cultural, histórico, capaz de

\footnotetext{
192 - David BUCKINGHAM. Crecer en la era de los medios electrónicos. Madrid. Morata, 2002, p. 58

193 - Jorge HUERGO. Cultura escolar, Cultura Mediática, Intersecciones. Bogotá, Universidad Pedagógica Nacional, 1999, p.228

194 - Idem, p.240
} 
significar e ressignificar, de diferentes maneiras, conteúdos e informações. Os estudantes passam a ser vistos como protagonistas que podem "aprender a aprender”, capacitando-se para o uso autônomo e crítico dos conteúdos, desenvolvendo habilidades de seleção, associação, interpretação e síntese de informações transformando-as em conhecimento.

Para finalizar, gostaríamos de lembrar que na quarta edição da “Cúpula Mundial de Mídia para Crianças e Adolescentes”, realizada em 2004, no Rio de Janeiro, jovens de vários países ressaltaram em manifesto, ao final do evento, que não querem apenas mídia de qualidade “para” eles, mas principalmente “com” eles. Enquanto os meios de massa, fechados em seu caráter comercial, não abrem espaço para a produção midiática de crianças e jovens, podemos encontrar nas escolas e em outras instituições educativas e culturais um terreno fértil para o planejamento e a implementação de projetos de "mediação tecnológica na educação” visando a potencializar a expressão e a competência comunicativa de crianças e adolescentes.

Nesse sentido, deixamos como sugestão que se busque ultrapassar os muros da escola e dar vazão a muitos quadros e programas radiofônicos produzidos durante e após o “educom.rádio”: promover a integração e a troca de informações e de materiais sonoros entre as diferentes escolas que realizam produções radiofônicas. Tais ações poderiam viabilizar, futuramente, um projeto de programa de rádio periódico que contemplasse produções de diferentes escolas. Por meio de parcerias com emissoras educativas ou comerciais ou, até mesmo, por meio da compra de horário viabilizada por patrocinadores e apoiadores do projeto, as comunidades educativas poderiam veicular seus conteúdos em programas coordenados por uma equipe de estudantes de diferentes unidades escolares. Ações como essas potencializariam ainda mais os resultados que verificamos na prática nas 
escolas pesquisadas, desenvolvendo nos alunos a criticidade, a responsabilidade, o companheirismo, a criatividade, a oralidade, e, enfim, a expressão comunicativa.

Acreditamos, finalmente, ter oferecido, por meio de uma pesquisa empírica, respostas às dúvidas ainda existentes de que a utopia proposta pelo NCE-USP às autoridades da Secretaria Municipal de Educação, em 2001, fazia e continua fazendo sentido. Acreditamos ter dado provas de que a Educomunicação vem se convertendo, efetivamente, em resposta aos problemas que emergem das relações entre diretores e professores, docentes e alunos, escola e comunidade do entorno. Sua aplicação, se ocorrer de forma adequada, converte-se, sem dúvida, em algumas das respostas que vêm sendo requeridas do sistema educativo pela “Sociedade da Informação”, no alvorecer do século XXI. Concordamos, assim, com Ismar de Oliveira Soares, quando afirma que "produzir comunicação tem se revelado a melhor forma de celebrar em plenitude o exercício da cidadania”. 


\section{$\underline{\text { Bibliografia }}$}

ALVES, Patrícia Horta. Educomunicação: A experiência do Núcleo de Comunicação e Educação - ECA/USP. Mestrado, ECA-USP, 2002

ARNHEIM, Rudolf. A Estética Radiofônica. Barcelona, ed. Gustavo Gilli, 1980

AZEVEDO, Adriana. “Alunos do educom.rádio levam mensagem de paz à UMESP”. In Boletim O Educomunicador num. 02, São Paulo, 2001, p.5 Disponível em www.usp.br/educomradio/download/boletim03.pdf. Acessado em 14/10/2006

Escola e Comunicação: o rádio como instrumento de cidadania. Disponível em www.usp.br/educomradio/cafe/cafe.asp?editoria=TSUPH\&cod=440. Acessado em 16/06/2004

AZEVEDO, Fernando de. A reconstrução educacional do Brasil. Ao Povo e ao Governo. Manifesto dos Pioneiros da Educação Nova. Rio de Janeiro: 1932

AZEVEDO, Maria Verônica Rezende de. Telejornalismo e Educação para a cidadania: experiência de educomunicação. Doutorado, ECA-USP, 2003

BACCEGA, Maria Aparecida. “Conhecimento, informação, tecnologia”. In Revista Comunicação \& Educação num.11. São Paulo, Ed. Moderna, 1998

“Comunicação na educação formal: processo de mudança”. Revista Comunicação \& Educação (9), São Paulo, Ed. Moderna, 1997

BABIN, Pierre \& KOULOUMDIJAN, Marie-France. Os novos modos de compreender. São Paulo, Ed. Paulinas, 1988

BARBOSA FILHO, André. Gêneros radiofônicos. Tipificação dos roteiros em rádio. São Bernardo do Campo. Mestrado, UMESP, 1996

BARI, Valéria Aparecida. Por uma epistemologia do campo da educomunicação: A interrelação comunicação e educação pesquisada nos textos geradores do I congresso internacional sobre comunicação e educação. Mestrado, ECA-USP, 2002

BARROSO, Julio \& CABERO, Julio \& DUARTE, Ana. La piedra angular para la incorporación de los medios audiovisuales, informáticos y nuevas tecnologías en los contextos educativos: la formación y el perfeccionamiento del profesorado. In: http://www.uib.es/depart/gte/edutec-e/revelec8/revelec8.html. Acessado em 28/05/2005 
BLOIS, Marlene. O rádio nosso de cada dia. In Revista Comunicação \& Educação (6), São Paulo, Ed. Moderna, 1996

BUCKINGHAM, David. Crecer en la era de los medios electrónicos. Madrid. Morata, 2002

CANCLINI, Néstor García. Culturas Híbridas. São Paulo: EDUSP, 1997

CASTELLS, Manuel. "Internet e sociedade em rede”. In MORAES, Denis (org). Por uma outra comunicação. Rio de Janeiro, Ed. Record, 2003

CITELLI, Adilson. Aprender e ensinar com textos não escolares. São Paulo: Cortez, 1997

São Paulo, 2002

Comunicação e Educação. A linguagem em movimento. Ed. Senac, 2ed.

COSTA, Maria Cristina Castilho. Educomunicador é preciso. Disponível em http://www.usp.br/nce/wcp/arq/textos/7.pdf. Acessado em 19/05/2006

DOWBOR, Landislau. Tecnologias do conhecimento: os desafios da comunicação. Petrópolis, Ed. Vozes, 2001

FONT, Fernando Fernandez. “Una propuesta alternativa. ¿Mas allá de la modernidad?” In Umbral XXI Número especial 3, Ciudad de México, 1996

FRANCO, Marília. Linguagens audiovisuais e cidadania. In Revista Comunicação \& Educação (9), São Paulo, Ed. Moderna, 1997

Ouvir e falar. Disponível em: www.educomradio.com.br/centro-oeste. Acessado em 14/08/2004.

FREIRE, Paulo. Extensão ou Comunicação. Editora Paz e Terra, Rio de Janeiro, 1979

GADOTTI, Moacir. "O plantador do futuro”. In Revista Viver Mente \& Cérebro num.4 Coleção Memória da Pedagogia, Ed. Segmento Duetto Editorial, São Paulo, 2005, p.6-15

GARDNER, Howard. Estruturas da mente. A teoria das inteligências múltiplas. Porto Alegre, Artes Médicas Sul, 1994.

HERRERA, Susana \&MARTÍNEZ, Maria del Pilar. Qué son los géneros radiofónicos y por qué deberían importarnos. Disponível em http://gmje.mty.itesm.mx/articulos3/articulo_7.html. Acessado em 11/11/2006

HUERGO, Jorge. “Comunicación/Educación: itinerarios transversales”. In VALDERRAMA, Carlos. Comunicación-Educación, Coordinadas, abordajes y travesías. Bogotá, Universidad Central/DIUC, 2000 
Cultura escolar, Cultura Mediática, Intersecciones. Bogotá, Universidad Pedagógica Nacional, 1999

La popularización de la ciencia y la tecnología. In http://www.redpop.org/publicaciones/mainlapopularizacion.html. Acessado em 02/07/2006

JORNAL FOLHA DE S. PAULO. Crianças devem redesenhar a escola, Revista da Folha, p.12, São Paulo, 05/02/2006

KAPLÚN, Mario. Processos educativos e canais de comunicação. In Revista Comunicação \& Educação (14), São Paulo, Ed, Moderna, 1999

LEVINSON, Paul. "Computer Conferencing in the Context of the Evolutions of Media”. In Harasim, L.M. Online Education. Perspectives on a New Environment. New York, Praeger Press, 1990, p. 3-14

LÉVY, Pierre. As tecnologias da inteligência - O futuro do pensamento na era da informática. Ed. 34, Rio de Janeiro, 1993

Cibercultura. São Paulo: Ed. 34, 1998

LIMA, Grácia Maria Lopes de. Educomunicação, Psicopedagogia e prática radiofônica. Estudo de caso do programa “Cala Boca Já Morreu”. Mestrado, ECA-USP, São Paulo, 2002

LOPES, Maria Immacolata Vassallo de. Pesquisa em Comunicação. São Paulo, Loyola, 7 ed, 2003

MARTÍN-BARBERO, Jesús. Dos meios às mediações. Rio de Janeiro, Ed. UFRJ, 1997

“Globalização comunicacional e transformação cultural”. In MORAES, Denis (org). Por uma outra comunicação. Rio de Janeiro, Ed. Record, 2003

Heredando el futuro. Pensar la educación desde la comunicación. Nómadas. Bogotá, Fundación Universidad Central, 1996

Buenos Aires, 2002

La Educación desde la Comunicación. Grupo Editorial Norma,

MARTINS, João Batista. Vygotsky \& a educação. Autêntica, Belo Horizonte, 2005

MONTEIRO, Eduardo e FELDMAN, Márcia. "Mídia-educação: formando cidadãos da era da informação” In Revista Pátio, num. 9, maio/jul. 1999 
MOREIRA, Manuel Area. Problemas y retos ante las tecnologías digitales en la Sociedad de La Información. Disponível em http://webpages.ull.es/users/manarea/documento 15.htm

MORIN, Edgard. Os sete saberes necessários à Educação do Futuro. Ed. Cortez, 9.ed, São Paulo, 2000

NCE-USP, Agenda do educom.rádio número 2, São Paulo, 2004

, Agenda do educom.rádio número 2B, São Paulo, 2004

, Boletim “O Educomunicador” Num.3, São Paulo, 2002

, Boletim “O Educomunicador” Num.24, São Paulo, 2004

OROZCO, Guillermo. “Elementos para uma política de educación mediática”. In VALDERRAMA, Carlos. Comunicación-Educación, Coordinadas, abordajes y travesías. Universidad Central/DIUC, Bogotá, 2000

, "Professores e meios de comunicação: desafios, estereótipos". In Revista Comunicação \& Educação (10), São Paulo, Ed. Moderna, 1997

PIAGET, Jean. Inteligencia y afectividad. Buenos Aires: Aique, 2001

POLLI, José Renato. "Freire e Habermas”. In Revista Viver Mente \& Cérebro num.4 Coleção Memória da Pedagogia, Ed. Segmento Duetto Editorial, São Paulo, 2005, p..56-65

ROSSETTI, Fernando. Mídia e escola - Perspectivas para políticas públicas. Edições Jogo de Amarelinha, São Paulo, 2005

SANTOS, Santa Marli Pires dos. O lúdico na formação do educador. Petrópolis: Vozes, RJ, 1997

SCHAUN, Angela. Educomunicação. Reflexões e princípios. Mauad Editora, Rio de Janeiro, 2002

SIERRA, Francisco. "Paradigmas y modelos teóricos de la comunicación educativa”. In VALDERRAMA, Carlos. Comunicación-Educación, Coordinadas, abordajes y travesías. Universidad Central/DIUC, Bogotá, 2000, p.49

SOARES, Ismar de Oliveira. A gestão da comunicação no espaço educativo (ou Os desafios da Era da Informação para o sistema educacional). Disponível em http://www.eca.usp.br/nucleos/nce/pdf/079.pdf Acessado em 08/01/2006

, "Caminhos da Educomunicação na América Latina e nos Estados Unidos”. In Caminhos da Educomunicação, 2.ed, Editora Salesiana, São Paulo, 2003 
, "Comunicação/Educação: a emergência de um novo campo e o perfil de seus profissionais” In Contato - Revista Brasileira de Comunicação, Arte e Educação num.2, Brasília: Senado Federal, jan/mar 1999, p.19-74

, "Educomunicação: as perspectivas do reconhecimento de um novo campo de intervenção social: o caso dos Estados Unidos”. In Eccos Revista Científica Uninove (v.2 n.2), dez 2000b

, "Educomunicación: comunicación y Tecnología de la Información en la reforma de la enseñanza americana”. In Dia-Logos de FELAFACS, n. 59-60, outubro de 2000, p. 137-152

USP), São Paulo, 2004

, Educommunication. Núcleo de Comunicação e Educação (NCE-

, From Media Education to Educommunication. Symposium on Media Education, Roma, 2003

"Lei de Diretrizes e Bases e a Comunicação no sistema de ensino”. In Revista Comunicação \& Educação (8), Ed. Moderna, São Paulo, 1997, p.23-26

, "Metodologias da educação para comunicação e gestão comunicativa no Brasil e na América Latina” In BACCEGA, Maria Aparecida, Gestão de processos comunicacionais, São Paulo-SP, Atlas, 2002

Nova, 1997

, Sociedade da informação ou da comunicação. São Paulo: Cidade

SOUSA, Mauro Wilton de. Novas linguagens. São Paulo, Editora Salesiana, 2001

. “O lugar social da comunicação mediática”. In Caminhos da Educomunicação, 2.ed, Editora Salesiana, São Paulo, 2003, p.21-34

TORRE, Alberto Efendy Maldonado Gómez de la. Pesquisa teórica em comunicação na América Latina (estudo de três casos relevantes: Verón, Mattelart e Martín). Doutorado, ECA/USP, 1999

TOSCHI, Mirza. "Linguagens midiáticas e formação de professores”. In ROSA, Dalva \& SOUZA, Vanilton (org). Didática e práticas de ensino: interfaces como diferentes saberes e lugares formativos. Rio de Janeiro, DP\&A Editora, 2002.

VALDERRAMA, Carlos. Comunicación-Educación, Coordinadas, abordajes y travesías. Universidad Central/DIUC, Bogotá, 2000

VATTIMO, Gianni. A sociedade transparente. Relógio d’Água. Lisboa, 1992 
VIGIL, José Ignácio López. Manual urgente para radialistas apaixonados. Ed. Paulinas, São Paulo, 1994

VYGOTSKY, Lev. Pensamento e linguagem. Ed. Martins Fontes, São Paulo, 2000

ZEFERINO, Genésio. Educomunicação e sua metodologia: um estudo a partir de práticas de ONGs no Brasil. Doutorado, ECA/USP, 2004 


\section{Anexo I - Roteiro de perguntas abertas para entrevistas com alunos, professores e coordenadores das escolas que compõem a amostragem}

1) Você ouve rádio:

（ ) não ouve rádio ～～～～～menos de 3 vezes por semana

( ) de 3 a 6 vezes por semana ( ) todos os dias

2) Em média, você ouve rádio quantas horas por dia?

( ) não ouve rádio ( ) menos de 1 hora

( ) de 1 a 3 horas ( ) mais de 3 horas

3) Quais emissoras de rádio você ouve com mais freqüência?

4) Quais os programas que você ouve com mais freqüência no rádio?

5) Quando sua escola participou do projeto “educom.rádio”?

6) Quando o equipamento de rádio foi instalado em sua escola?

7) Quem participa do funcionamento da rádio?

( ) Diretoria ( ) Professores ( ) Funcionários ( ) Alunos ( ) Comunidade

8) Como e com que periodicidade a equipe se reúne?

9) Das pessoas que fizeram o curso do “educom.rádio” quais participam do uso do rádio?

10) Outras pessoas da escola que não haviam feito o curso se envolveram com a prática radiofônica? Quem são elas?

11) Como ocorreu a formação dessas pessoas que passaram a adotar as práticas educomunicativas e a se envolver com os programas de rádio?

12) Que outros meios de comunicação ou tecnologias de informação são utilizados na escola?

13) Eles interagem com o uso do rádio ou as atividades com cada mídia são independentes? 
14) Quem apóia o uso do rádio na escola?

( ) Diretoria ( ) Professores ( ) Funcionários ( ) Alunos ( ) Comunidade

15) Quem não apóia o uso do rádio na escola?

( ) Diretoria ( ) Professores ( ) Funcionários ( ) Alunos ( ) Comunidade

16) Quais as principais facilidades para fazer programas e usar a rádio com freqüência na escola?

17) Quais as principais dificuldades para fazer programas e usar a rádio com freqüência na escola?

18) Como são decididos as pautas e os formatos dos programas?

19) Quais os formatos mais utilizados nos programas?

20) Quais os temas mais abordados nos programas?

21) Há um controle ou uma avaliação da qualidade e dos conteúdos dos programas?

22) Foi estabelecido um código de ética ou algo semelhante para que o grupo saiba o que é permitido e/ou proibido nos programas de rádio?

23) Você percebe algumas semelhanças em relação à programação da rádio na escola e os programas das rádios comerciais? Quais?

24) Você percebe algumas diferenças em relação à programação da rádio na escola e os programas das rádios comerciais? Quais?

25) O rádio é mais usado com intenção pedagógica para disciplinas curriculares ou em atividades extra-classe e extra-curriculares?

26) Dê exemplos em que o rádio é mais usado em atividades extra-classe e extracurriculares.

27) Dê exemplos em que o rádio é mais usado para disciplinas curriculares. 
28) Quais as disciplinas do Ensino Fundamental que são mais contempladas nos temas dos programas de rádio na escola?

29) Que vantagens e/ou desvantagens a rádio trouxe à escola? Por quê?

30) Por que você se envolveu com a rádio da escola?

31) Que temas ainda não foram contemplados na rádio que você gostaria de abordar?

32) Que gênero ou formato de programa você gostaria que estivesse mais presente na programação da rádio?

33) Algum programa da rádio já foi exibido fora da sua escola? Em outras escolas, em rádios comunitárias ou comerciais, na Internet, etc?

34) Quais as perspectivas para o uso do rádio na sua escola daqui em diante? 


\section{Anexo II - Modelo de questionário para alunos}

ESCOLA:

SÉRIE:

IDADE:

\begin{tabular}{|c|c|c|c|c|c|}
\hline $\begin{array}{l}\text { Ao me envolver com a criação e } \\
\text { produção de programas de rádio na } \\
\text { escola: }\end{array}$ & $\begin{array}{l}\text { Discordo } \\
\text { totalmente }\end{array}$ & $\begin{array}{l}\text { Discordo } \\
\text { em parte }\end{array}$ & \begin{tabular}{|c|} 
Nem \\
discordo \\
nem \\
concordo \\
\end{tabular} & $\begin{array}{l}\text { Concordo } \\
\text { em parte }\end{array}$ & $\begin{array}{l}\text { Concordo } \\
\text { totalmente }\end{array}$ \\
\hline \multicolumn{6}{|l|}{$\begin{array}{l}\text { Percebo que melhorou minha relação com } \\
\text { os professores e funcionários. }\end{array}$} \\
\hline \multicolumn{6}{|l|}{$\begin{array}{l}\text { Percebo que os professores que se } \\
\text { envolvem com a rádio me respeitam mais } \\
\text { e dão espaço para eu expressar minhas } \\
\text { idéias. }\end{array}$} \\
\hline \multicolumn{6}{|l|}{$\begin{array}{l}\text { Aprendi a trabalhar melhor em grupo, } \\
\text { cooperando com meus amigos e colegas. }\end{array}$} \\
\hline \multicolumn{6}{|l|}{$\begin{array}{l}\text { Estou mais consciente sobre o que } \\
\text { acontece na escola e na comunidade ao } \\
\text { redor dela, tenho mais contato com a } \\
\text { comunidade. }\end{array}$} \\
\hline \multicolumn{6}{|l|}{$\begin{array}{l}\text { Fiquei mais preparado para fazer leitura } \\
\text { crítica dos meios de comunicação. Tenho } \\
\text { mais noção de como se fazem programas } \\
\text { e como se escolhem os temas. }\end{array}$} \\
\hline \multicolumn{6}{|l|}{$\begin{array}{l}\text { Sinto-me mais feliz e motivado ao saber } \\
\text { que outras pessoas estão ouvindo o } \\
\text { programa em que aparece minha voz ou } \\
\text { que eu ajudei a fazer. }\end{array}$} \\
\hline \multicolumn{6}{|l|}{$\begin{array}{l}\text { Estou me sentindo menos tímido e mais } \\
\text { solto para falar em público e dialogar } \\
\text { com as pessoas. }\end{array}$} \\
\hline \multicolumn{6}{|l|}{$\begin{array}{l}\text { Tenho desenvolvido mais minha } \\
\text { criatividade. }\end{array}$} \\
\hline \multicolumn{6}{|l|}{ Percebo que fiquei mais responsável. } \\
\hline \multicolumn{6}{|l|}{ Estou mais atento e disciplinado. } \\
\hline \multicolumn{6}{|l|}{$\begin{array}{l}\text { Melhorei minha capacidade de } \\
\text { questionar, criticar e argumentar. }\end{array}$} \\
\hline \multicolumn{6}{|l|}{$\begin{array}{l}\text { Preocupo-me em pesquisar os assuntos e } \\
\text { temas que serão abordados nos } \\
\text { programas. }\end{array}$} \\
\hline \multicolumn{6}{|l|}{$\begin{array}{l}\text { Percebo que estou mais preparado para } \\
\text { saber selecionar e organizar informações. }\end{array}$} \\
\hline $\begin{array}{l}\text { Consigo aprender e me divertir ao mesmo } \\
\text { tempo quando faço os programas. }\end{array}$ & & & & & \\
\hline
\end{tabular}




\title{
Anexo III - Modelo de questionário para professores e coordenadores
}

\author{
ESCOLA:
}

FUNÇÃO:

\begin{tabular}{|c|c|c|c|c|c|}
\hline $\begin{array}{l}\text { Observando e convivendo com crianças e } \\
\text { jovens que produzem programas de rádio } \\
\text { na escola percebo que: }\end{array}$ & $\begin{array}{l}\text { Discordo } \\
\text { totalmente }\end{array}$ & $\begin{array}{l}\text { Discordo } \\
\text { em parte }\end{array}$ & $\begin{array}{c}\text { Nem } \\
\text { discordo } \\
\text { nem } \\
\text { concordo }\end{array}$ & $\begin{array}{l}\text { Concordo } \\
\text { em parte }\end{array}$ & $\begin{array}{l}\text { Concordo } \\
\text { totalmente }\end{array}$ \\
\hline \multicolumn{6}{|l|}{$\begin{array}{l}\text { Melhorou a relação dos alunos com os } \\
\text { professores e funcionários. }\end{array}$} \\
\hline \multicolumn{6}{|l|}{$\begin{array}{l}\text { Os professores que se envolvem com a } \\
\text { rádio respeitam mais os alunos e dão } \\
\text { espaço para eles expressarem suas idéias. }\end{array}$} \\
\hline \multicolumn{6}{|l|}{$\begin{array}{l}\text { Os alunos aprenderam a trabalhar melhor } \\
\text { em grupo, cooperando com seus amigos e } \\
\text { colegas. }\end{array}$} \\
\hline \multicolumn{6}{|l|}{$\begin{array}{l}\text { Os estudantes ficaram mais conscientes } \\
\text { sobre o que acontece na escola e na } \\
\text { comunidade ao redor dela, têm mais } \\
\text { contato com a comunidade. }\end{array}$} \\
\hline \multicolumn{6}{|l|}{$\begin{array}{l}\text { Os alunos estão mais preparados para } \\
\text { fazer leitura crítica dos meios de } \\
\text { comunicação. Têm mais noção de como } \\
\text { se fazem programas e como se escolhem } \\
\text { os temas. }\end{array}$} \\
\hline \multicolumn{6}{|l|}{$\begin{array}{l}\text { Os estudantes se sentem mais felizes e } \\
\text { motivados ao saber que outras pessoas } \\
\text { estão ouvindo programas em que } \\
\text { aparecem sua voz ou que ajudaram a } \\
\text { fazer. }\end{array}$} \\
\hline \multicolumn{6}{|l|}{$\begin{array}{l}\text { Os alunos estão menos tímidos e mais } \\
\text { soltos para falar em público e dialogar } \\
\text { com as pessoas. }\end{array}$} \\
\hline \multicolumn{6}{|l|}{$\begin{array}{l}\text { Os estudantes desenvolvem mais a } \\
\text { criatividade. }\end{array}$} \\
\hline \multicolumn{6}{|l|}{ Os alunos ficaram mais responsáveis. } \\
\hline \multicolumn{6}{|l|}{$\begin{array}{l}\text { Os estudantes estão mais atentos e } \\
\text { disciplinados. }\end{array}$} \\
\hline \multicolumn{6}{|l|}{$\begin{array}{l}\text { Os alunos melhoraram sua capacidade de } \\
\text { questionar, criticar e argumentar. }\end{array}$} \\
\hline \multicolumn{6}{|l|}{$\begin{array}{l}\text { Os estudantes se preocupam em pesquisar } \\
\text { os assuntos e temas que serão abordados } \\
\text { nos programas. }\end{array}$} \\
\hline \multicolumn{6}{|l|}{$\begin{array}{l}\text { Os alunos estão mais preparados para } \\
\text { selecionar e organizar informações. }\end{array}$} \\
\hline $\begin{array}{l}\text { Os estudantes conseguem aprender e se } \\
\text { divertir ao mesmo tempo quando fazem } \\
\text { os programas. }\end{array}$ & & & & & \\
\hline
\end{tabular}

